UNIVERSIDADE DE SÃO PAULO

INSTITUTO DE QUÍMICA DE SÃO CARLOS

UNIVERSIDAD AUTÓNOMA DE MADRID

FACULTAD DE CIENCIAS

JOSIAS FALARARO PAGOTTO

\title{
MÉTODOS DE PROTEÇÃO CONTRA A CORROSÃO DE LIGAS
} METÁLICAS

Orientadores: Prof. Dr. Artur de Jesus Motheo

Profa. Dra. Pilar Herrasti González

São Carlos 


\section{MÉTODOS DE PROTEÇÃo CONTRA A CORROSÃO DE LIGAS METÁLICAS}

Tese apresentada ao Instituto de Química de São Carlos da Universidade de São Paulo (Brasil), e à Facultad de Ciencias da Universidad Autónoma de Madrid (Espanha), como parte dos requisitos para a obtenção dos títulos de Doutor em Ciências: Química (Área de Concentração: Físico-Química) e Doutor em Ciências: Química (Área de Concentração: Eletroquímica - Ciencia e Tecnologia).

Orientadores: Prof. Dr. Artur de Jesus Motheo

Profa. Dra. Pilar Herrasti González 
Autorizo a reprodução e divulgação total ou parcial deste trabalho, por qualquer meio convencional ou eletrônico, para fins de estudo e pesquisa, desde que citada a fonte. 


\section{AGRADECIMENTOS}

- Primeiramente à Deus, pelo dom da vida e Seu Constante auxílio e ajuda;

- Ao professor e amigo Artur de Jesus Motheo, pela orientação do trabalho de tese, a quem devo inúmeros aprendizados, pelas repreensões quando necessário, e por sua amizade e paciência para ser mais que um orientador durante todo o período;

- À Profa. Pilar Herrasti González, pela orientação e amizade, e pelo constante apoio e disponibilidade durante o período em que estive na Espanha, e após retorno ao Brasil;

- Ao Dr. Javier Recio, pela participação no trabalho e inúmeras discussões dos resultados;

- Às professoras Alda Simões e Fátima Montemor, de Lisboa, pela colaboração com as análises de corrosão localizadas, onde me proporcionaram grande aprendizado nestas técnicas de análise;

- À todo pessoal do Laboratório de Eletroquímica Interfacial, pela amizade e bons momentos juntos;

- À todo pessoal do IQSC, da sessão de pós graduação, da CAQI, oficinas e pessoal da manutenção;

- Ao grupo da Profa. Pilar, em Madri, da Profa. Alda, em Lisboa, e do pessoal do apartamento em que morei;

- À USP (IQSC), à Universidad Autónoma de Madrid (Facultad de Ciencias) e à Universidade Técnica de Lisboa (Instituto Superior Técnico), que em conjunto, me ofereceram todo suporte e infraestrutura para desenvolvimento deste trabalho de tese;

- Às agências CAPES e CNPq, pelo auxílio financeiro durante todo o período.

- À minha família, minha mãe, meu pai, minhas irmã (a Nê e a Vi), meu sobrinho Daniel, cunhado (aprendiz de pilotagem), e todos que, perto ou longe, estão presentes em minha vida;

- À Dani, por todo amor e carinho, meu sogro Daniel e toda sua família;

- Aos amigos Neto, Felipe, Eliézer, Guilherme, o Yuri, e tantos outros cujo espaço seria pequeno para citar;

- Aos irmãos e amigos, que me receberam e me trataram com grande hospitalidade, qualquer parte do mundo que fosse; 
DEDICATÓRIA

Áminha familia, dada por Deus...

$\dot{Q} \mathscr{D}_{\text {ani, por kodo seu amor e }}$ carinho... 


\section{Resumo}

Neste trabalho foram estudadas soldas TIG (Tungsten Inert Gas) nos aços inoxidáveis 304 e 316, e no aço carbono 1020. As alterações das microestruturas foram investigadas por microscopias óptica (MO) e eletrônica de varredura (MEV), enquanto que a corrosão destas regiões foi estudada por análises de polarização potenciodinâmica. Um sistema miniaturizado de análise corrosão, denominado sensor pontual de corrosão (SPC), foi utilizado com o objetivo de analisar a estreita região dos cordões de solda, estudando assim a influência da corrente de solda na corrosão desta região nos aços inoxidáveis 304 e 316. Os resultados mostraram que a alteração da estrutura cristalina na solda tornou esta região menos susceptível à corrosão que o material base, e o aumento da corrente de solda intensificou ainda mais este efeito, pela formação de estruturas mais compactas. No caso do aço carbono 1020 (mais susceptível à corrosão), o estudo da corrosão de sua solda foi feito utilizando técnicas eletroquímicas globais (potencial de circuito aberto, PCA, e espectroscopia de impedância eletroquímica, EIE) e técnicas de corrosão localizadas (espectroscopia de impedância eletroquímica localizada, EIEL, e técnica do eletrodo vibratório de varredura, TEVV). Para proteção contra a corrosão do aço inoxidável e suas soldas, foi utilizado um revestimento de polianilina (PAni) na forma de base esmeraldina; análises de polarização potenciodinâmica mostraram a eficiência deste revestimento protetor. Para o aço carbono 1020, devido à sua maior facilidade de oxidação, foi sintetizado um revestimento protetor a base de PAni e nanotubos de $\mathrm{TiO}_{2}\left(\mathrm{PAni} / \mathrm{n}-\mathrm{TiO}_{2}\right)$. As variáveis estudadas na síntese do polímero foram: temperatura de síntese, meio reacional, grau de dopagem do polímero (condutor ou isolante) e número de camadas. Os polímeros e compósitos foram caracterizados por espectroscopias nas regiões do ultravioleta-visível (UV-vis) e infravermelho (IV), MEV e espectroscopia de energia dispersiva de raios-X (EDX). Os aços recobertos com os filmes foram analisados por MO e MEV, EDX, e por ensaios eletroquímicos de polarização potenciodinâmica, PCA e resistência de polarização, além de ensaio de corrosão acelerada em câmara de névoa salina. As melhores condições encontradas foi para o revestimento de $\mathrm{PAni} / \mathrm{n}-\mathrm{TiO}_{2}$ desdopado (base esmeraldina) sintetizado a $25^{\circ} \mathrm{C}$ em meio de $\mathrm{H}_{2} \mathrm{SO}_{4}$, e com 3 camadas; o $\mathrm{n}-\mathrm{TiO}_{2}$ apresentou um efeito de aumento da aderência do filme ao substrato metálico.

Palavras-chave: Aços, Solda TIG, PAni/n- $\mathrm{TiO}_{2}$ 


\begin{abstract}
In this work TIG (Tungsten Inert Gas) welds have been studied in the 304 and 316 stainless steels, and in the 1020 carbon steel. The changes in the microstructure were investigated by optical microscope $(\mathrm{OM})$ and scanning electronic microscope (SEM), and the corrosion behavior in these zones were studied by potentiodynamic polarization analysis. A miniaturized corrosion analysis device, named corrosion punctual sensor, has been used to analyze the close weld bead, researching for the influence of the weld current in the corrosion process in this zone of the 304 and 316 stainless steels. The results showed that the change in the crystalline structure of the weld zone became this region less susceptible to corrosion process than their base material, and the increase in the weld current intensified this effect, by the formation of more compact structures. In the case of the 1020 carbon steel (more susceptible to corrosion processes), the corrosion in its weld zone was researched by global (like open potential circuit, OCP, and electrochemical impedance spectroscopy, EIS) and localized (like localized electrochemical impedance spectroscopy, LEIS, and scanning vibrating electrode technique, SVET) electrochemical techniques. For protecting stainless steels and their weld zones against corrosion processes, a polyaniline (PAni) coating in the emeraldine base form was used; potentiodynamic polarization analysis showed the efficiency of this protective coating. For the 1020 carbon steel, due to its mayor oxidation susceptibly, a protective coating of PAni and $\mathrm{TiO}_{2}$ nanotubes $\left(\mathrm{PAni} / \mathrm{n}-\mathrm{TiO}_{2}\right)$ was synthesized. The variables researched were: synthesis temperature, reaction medium, degree of doping of the polymer (conductor or insulator) and number of layers. The polymers and composites were characterized by ultraviolet visible (UV-vis) and infrared spectroscopies, SEM and Energy Dispersive X-Ray Spectroscopy (EDX). The coated steels were analyzed by OM, MEV and EDX spectroscopies, and by potentiodynamic polarization, OCP and polarization resistance electrochemical measurements, besides accelerate corrosion tests in a salt spray chamber. The best conditions found for the dedoped $\mathrm{PAni} / \mathrm{n}-\mathrm{TiO}_{2}$ coatings (emeraldine base) were: temperature of synthesis of $25^{\circ} \mathrm{C}, \mathrm{H}_{2} \mathrm{SO}_{4}$ as reaction medium, and with 3 layers; $\mathrm{n}-\mathrm{TiO}_{2}$ has presented an effect of increasing the adherence of the coating with the steel.
\end{abstract}

Keywords: Steels, TIG Weld; PAni/n- $-\mathrm{TiO}_{2}$ 


\section{Resumen}

En este trabajo se muestra el estudio realizado para soldaduras TIG (Tungsten Inert Gas) en aleaciones de acero inoxidable 304 y 316, acero al carbono 1020. Las alteraciones microestructurales fueron investigadas por microscopias óptica electrónica de barrido (SEM), mientras que en el estudio de la corrosión de estas regiones se utilizaron técnicas de polarización potenciodinámica. Un sistema miniaturizado de análisis de corrosión, denominado sensor puntual de corrosión (SPC), fue utilizado con el fin de garantizar que solo la soldadura era el objeto de estudio, analizando así la influencia de la corriente de soldadura en la corrosión de esta región en los aceros inoxidable 304 y 316. Los resultados obtenidos mostraron que la alteración de la estructura cristalina en la soldadura provoca una menor susceptibilidad a la corrosión si se compara con el materia base, siendo esta respuesta más intensa cuando se utilizan corrientes de soldaduras mayores, debido a la formación de estructuras más compactas. En el caso del acero al carbono 1020 (más susceptible a la corrosión), el estudio de la corrosión en la soldadura se realizó empleando técnicas electroquímicas globales (potencial de circuito abierto, PCA, e espectroscopia de impedancia electroquímica, EIE) en conjunto a las técnicas de corrosión localizadas (espectroscopia de impedancia electroquímica localizada, EIEL, y técnica del electrodo vibratorio de barrido, TEVB). Para la protección contra la corrosión de los aceros inoxidables y sus soldaduras, se utilizaron revestimientos de polianilina, en su forma de base esmeraldina. Los resultados derivados del análisis de las curvas de polarización potenciodinamica mostraron la eficiencia de esta película protectora. Para el acero al carbono 1020, debido a su mayor corrosión, fue sintetizado un recubrimiento protector de polianilina con nanotubos de $\mathrm{TiO}_{2}\left(\mathrm{PAni} / \mathrm{n}-\mathrm{TiO}_{2}\right)$. Se estudiaron diferentes variables como: temperatura de síntesis, medio de síntesis, grado de dopaje del polímero (conductor o aislante) y numero de capas. Los polímeros y compositos fueron caracterizados por espectroscopia en las regiones del UV-vis e infrarrojo, SEM y espectroscopia de energía dispersiva de rayos-X (EDX). Los aceros recubiertos con las películas fueran analizados por microscopia óptica, SEM y EDX y por último se llevaron a cabo ensayos de corrosión empleando polarización potenciodinamica, potencial de circuito abierto, resistencia de polarización, y ensayos de corrosión aceleradas en cámara de niebla salina. Las mejores condiciones encontradas fueron para el revestimiento de $\mathrm{PAni} / \mathrm{n}-\mathrm{TiO}_{2}$ desdopado (base esmeraldina) sintetizado a $25^{\circ} \mathrm{C}$ en medio de $\mathrm{H}_{2} \mathrm{SO}_{4}$, y con tres capas; el n$\mathrm{TiO}_{2}$ presentó un efecto de aumento de la adherencia de la película sobre el sustrato metálico. Palabras-clave: Aceros, Soldadura TIG, PAni/n- $\mathrm{TiO}_{2}$ 


\section{Lista de ilustrações}

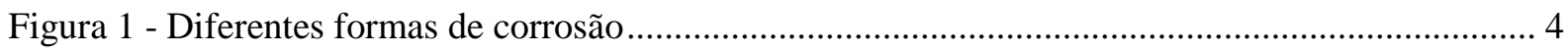

Figura 2 - Mecanismo de formação do pite por ação do $\mathrm{Cl}^{-}$em metais .................................................. 5

Figura 3 - Diferentes zonas presentes na região de solda.................................................................. 10

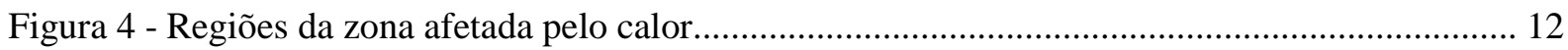

Figura 5 - Estruturas cristalinas: cúbica de corpo centrado e cúbica de face centrada.......................... 12

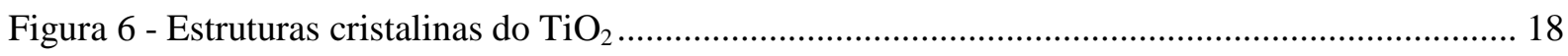

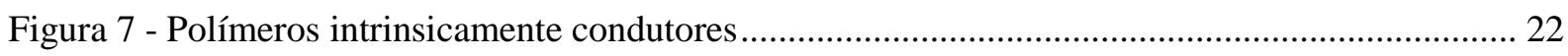

Figura 8 - Modelo de bandas para um polímero condutor ................................................................. 22

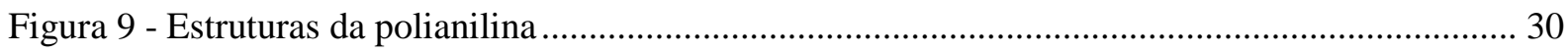

Figura 10 - Mecanismo de interconversão entre os estados da PAni ................................................... 32

Figura 11 - Mecanismo de passivação do aço pela PAni com presença de defeito no filme ................. 34

Figura 12 - Sistema utilizado para síntese química de polímero.......................................................... 43

Figura 13 - Célula usada nos ensaios eletroquímicos de corrosão em meio de cloreto. ........................ 43

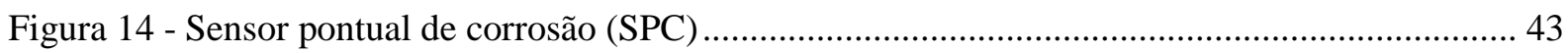

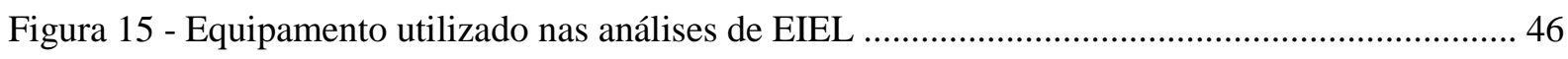

Figura 16 - Equipamento utilizado nas análises pela TEVV .............................................................. 46

Figura 17 - Eletrodo auxiliar de Pt e eletrodo de referência de calomelanos saturado .......................... 46

Figura 18 - Montagem experimental do "eletrodo duplo" ..................................................................... 47

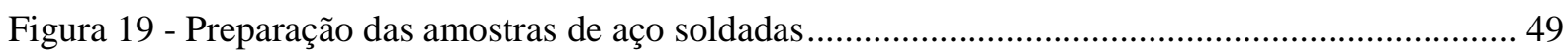

Figura 20 - Representação de E em função de log i para análise de corrosão ...................................... 52

Figura 21 - Diagramas de impedância eletroquímica......................................................................... 54

Figura 22 - Aços 304 e 316 soldados a partir de diferentes correntes de solda .................................... 62

Figura 23 - Microestruturas dos aços 304 e 316 com diferentes correntes de solda ............................... 63

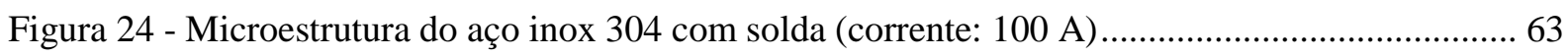

Figura 25 - Microestrutura do aço inox 316 com solda (corrente: 100A) ........................................... 64

Figura 26 - Microestrutura do aço carbono 1020 com solda (corrente: 100 A)................................... 66

Figura 27 - Imagens da microestrutura do aço carbono 1020 com solda (corrente: 100 A)................ 66

Figura 28 - Curvas de polarização potenciodinâmica utilizando a célula convencional e o SPC......... 69

Figura 29 - Imagens após polarização potenciodinâmica dos aços na célula convencional e SPC ...... 69

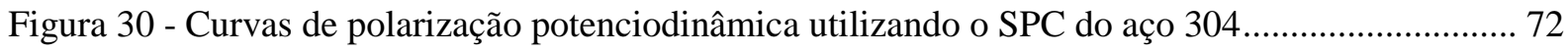


Figura 31 - Curvas de polarização potenciodinâmica utilizando o SPC do aço 316. 72

Figura 32 - Aços com diferentes soldas após polarização utilizando a célula convencional ................ 74

Figura 33 - Aços com solda após polarização potenciodiâmica utilizando a cél. convencional ............ 75

Figura 34 - Análise de EDX nas regiões de solda dos aços com solda de 100 A …............................... 77

Figura 35 - Análise por EDX da região de solda (100 A) em aço 304.................................................. 78

Figura 36 - Aços com diferentes soldas após polarização potenciodinâmica utilizando o SPC ........... 79

Figura 37 - Aço 316 com solda de 100 A recoberto com PAni ........................................................... 80

Figura 38 - Polarização potenciodinâmica utilizando o SPC dos aços soldados com PAni .................. 80

Figura 39 - Aço com solda após polarização, com revestimento de PAni e após sua remoção............. 83

Figura 40 - Análise de potencial de circuito aberto de aço 1020 com solda ......................................... 86

Figura 41 - Análise de EIE (Nyquist) em aço carbono 1020 com solda ............................................. 88

Figura 42 - Análise de EIE (Bode) em aço carbono 1020 com solda ................................................... 88

Figura 43 - Circuito elétrico utilizado para fazer os ajustes nas curvas de EIE ................................... 88

Figura 44 - Variação da capacitância com o tempo para aço carbono 1020 ......................................... 89

Figura 45 - Diagrama de Bode após 2h de imersão do aço 1020 com solda......................................... 91

Figura 46 - Tipos de medidas feitas nas análises de corrosão localizadas ............................................. 91

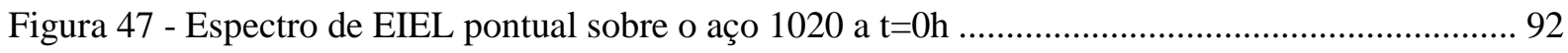

Figura 48 - Análise por EIEL ( $\mathrm{f}=1,0 \mathrm{kHz}$ ) feito em aço 1020 com solda .......................................... 92

Figura 49 - Análise por EIEL ( $\mathrm{f}=1,0 \mathrm{~Hz}$ ) feito em aço 1020 com solda .......................................... 93

Figura 50 - Linhas de campo de um eletrodo devido a um processo de corrosão................................... 94

Figura 51 - Análises pela TEVV e microscopia óptica em aço 1020 com solda ................................. 96

Figura 52 - Análise pela TEVV e MO do aço 1020 com solda.............................................................. 97

Figura 53 - Análise da densidade de corrente de corrosão nos mapas de TEVV ................................. 100

Figura 54 - Análise comparativa por EIEL, TEVV e MO, em aço 1020 ........................................... 101

Figura 55 - Imagens do aço 1020 após $24 \mathrm{~h}$ em $\mathrm{NaCl}$...................................................................... 102

Figura 56 - Aço carbono com recobrimentos dopados, após polarização anódica (SPC)................... 105

Figura 57 - Aço carbono com recobrimentos desdopados, após polarização anódica (SPC) .............. 105

Figura 58 - Polarização potenciodinâmica (SPC) de aços carbono com recobrimentos ...................... 106

Figura 59 - Perfis de potencial e temperatura durante a síntese da PAni e PAni/n- $\mathrm{TiO}_{2} \ldots \ldots \ldots \ldots \ldots \ldots . . . . . . .108$

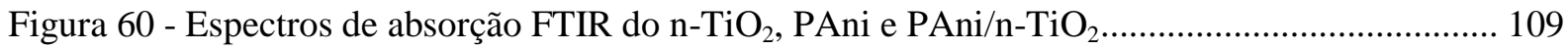

Figura 61 - Espectros de absorção UV-vis dos polímeros em NMP, dopado e desdopado ................. 111 
Figura 62 - Análise do n- $\mathrm{TiO}_{2}$ por MEV

Figura 63 - MEV dos polímeros e compósitos dopados (em pó)

Figura 64 - MEV dos polímeros e compósitos desdopados (em pó).

Figura 65 - Análise de EDX nos compósitos Pani/n-TiO 2 (em pó) 114

Figura 66 - Mapeamento de elementos químicos na amostra de PAni/n-TiO 116

Figura 67 - Aços 1020 com 1 camada de diferentes recobrimentos. 118

Figura 68 - Microscopia óptica de aços 1020 com 1 camada de diferentes recobrimentos 118

Figura 69 - MEV de aços 1020 com 1 camada de diferentes recobrimentos 119

Figura 70 - Polarização potenciodinâmica de aço 1020 com 1 cam. de diferentes recobrimentos 120

Figura 71 - Aços 1020 com 1 camada de revestimento, após polarização potenciodinâmica 121

Figura 72 - Microscopia óptica de aço 1020 com 1 camada de revestimento, após polarização.

Figura 73 - Aços 1020 com 1 camada de revestimento, após remoção dos mesmos.....

Figura 74 - MO dos aços 1020 com 1 camada de revestimento, e após remoção do mesmo 122

Figura 75 - Potencial de circuito aberto de aço 1020 com diferentes recobrimentos. 124

Figura 76 - Polarização potenciodinâmica de aço 1020 com multicamadas..... 126

Figura 77 - Aços 1020 com recobrimentos multicamadas 127

Figura 78 - Microscopia óptica de aços 1020 com recobrimentos multicamadas

Figura 79 - MEV de aços 1020 com recobrimentos multicamadas de PAni e PAni/n-TiO 128

Figura 80 - Aço 1020 com multicamadas de PAni, após polarização e remoção dos recobrimentos . 131

Figura 81 - Aços (MO) 1020 com multicamadas de PAni, após polarização e remoção dos recobrimentos.

Figura 82 - Aços 1020 com multicamadas de PAni/n-TiO 2 após polarização e remoção dos recobrimentos

Figura 83 - MO de aços 1020 com multicamadas, após polarização e remoção dos recobrimentos .. 132 Figura 84 - Análise da composição química de filme de $\mathrm{PAni} / \mathrm{n}-\mathrm{TiO}_{2}$ sobre aço 1020. 133

Figura 85 - Mapeamento de filme de PAni/n-TiO 2 (imagem com menor ampliação) 133

Figura 86 - Mapeamento de filme de $\mathrm{PAni} / \mathrm{n}-\mathrm{TiO}_{2}$ (imagem com maior ampliação) 134

Figura 87 - Aço sem recobrimento submetido a ensaio em camada de névoa salina. 135

Figura 88 - Aço 1020 com PAni, submetido a ensaio em camada de névoa salina 136

Figura 89 - Aço 1020 com PAni/n-TiO ${ }_{2}$, submetido a ensaio em camada de névoa salina 136

Figura 90 - Montagem experimental de aço 1020 com solda e recobrimento, para análise TEVV .... 137

Figura 91 - TEVV e microscopia óptica de aço 1020 com solda, revestida com $\mathrm{PAni} / \mathrm{n}-\mathrm{TiO}_{2}$ 137 


\section{Lista de tabelas}

Tabela 1 - Propriedades físico-químicas das diferentes estruturas da polianilina................................. 30

Tabela 2 - Composição química nominal dos aços inoxidáveis, e do aço carbono................................. 42

Tabela 3 - Parâmetros eletroquímicos de aços inox, utilizando a célula convencional e o SPC........... 69

Tabela 4 - Parâmetros eletroquímicos do aço 304 com diferentes correntes de solda ........................... 72

Tabela 5 - Parâmetros eletroquímicos do aço 316 com diferentes correntes de solda ........................... 73

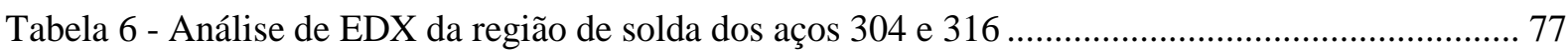

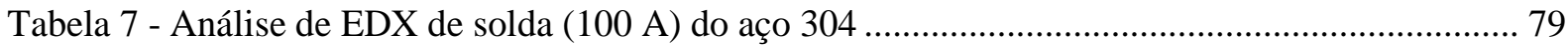

Tabela 8 - Parâmetros eletroquímicos de soldas do aço 304 recobertos com PAni ............................... 81

Tabela 9 - Parâmetros eletroquímicos de soldas do aço 316 recobertos com PAni ............................... 81

Tabela 10 - Parâmetros eletroquímicos obtidos das análises de EIE do aço 1020 ................................. 89

Tabela 11 - Parâmetros eletroquímicos obtidos de aços 1020 com diferentes recobrimentos ............. 106

Tabela 12 - Bandas do n- $\mathrm{TiO}_{2}$, PAni e PAni/n- $\mathrm{TiO}_{2}$ na análise por espectroscopia FTIR ................. 109

Tabela 13 - Composição química de $\mathrm{PAni} / \mathrm{n}-\mathrm{TiO}_{2}$ (em pó) dopado e desdopado................................ 114

Tabela 14 - Parâmetros eletroquímicos de aços 1020 com 1 camada de recobrimentos....................... 120

Tabela 15 - Parâmetros eletroquímicos de aços 1020 com multicamadas .......................................... 126

Tabela 16 - Composição química de filme de $\mathrm{PAni} / \mathrm{n}-\mathrm{TiO}_{2}$ sobre aço 1020 ...................................... 133 


\section{Sumário}

CAPÍTULO I - INTRODUÇÃO ............................................................................... 1

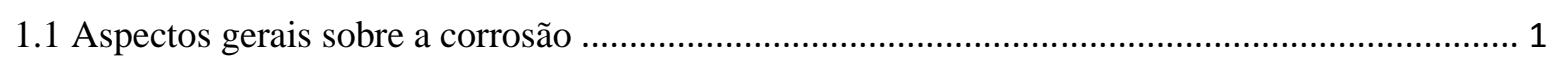

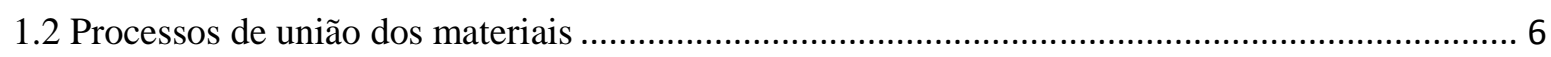

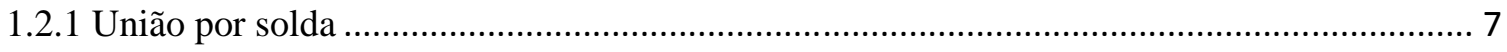

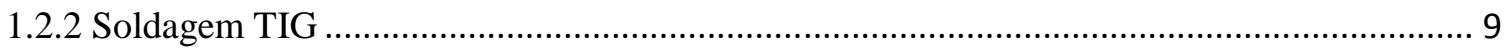

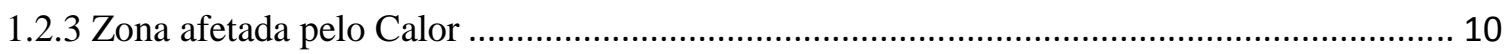

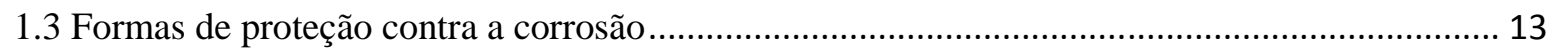

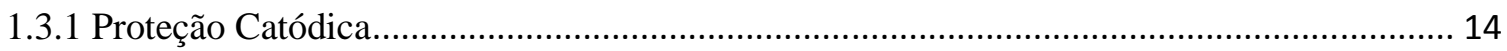

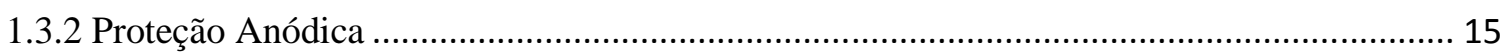

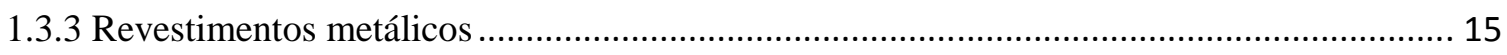

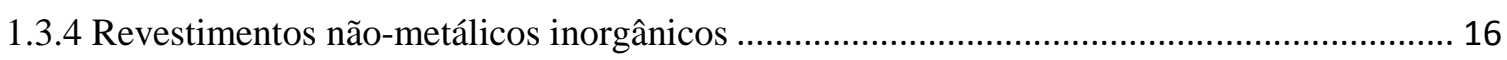

1.3.5 Revestimentos não-metálicos orgânicos (tintas e polímeros) …………............................. 17

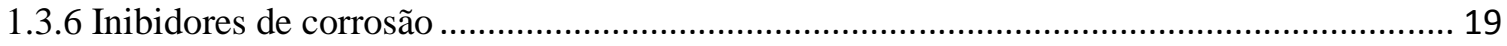

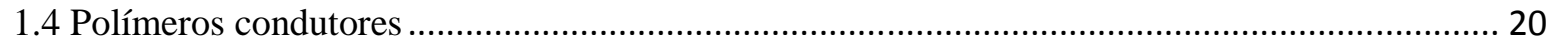

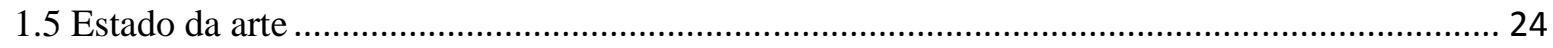

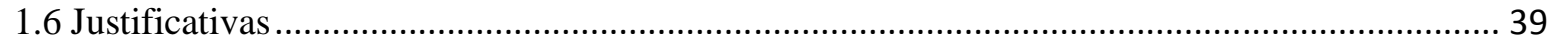

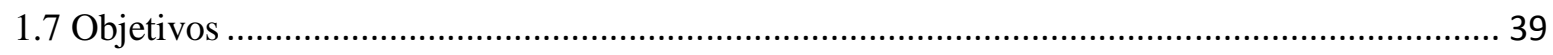

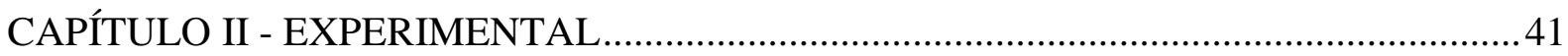

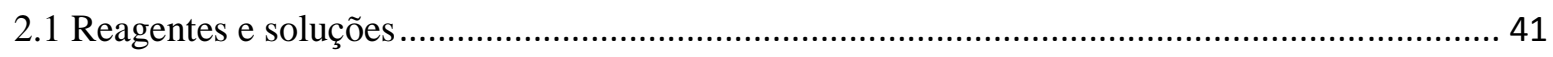

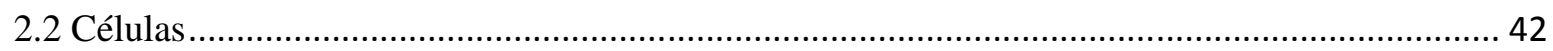

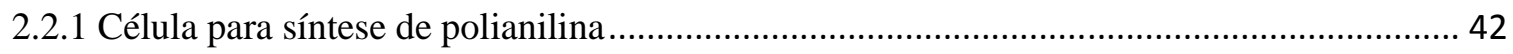

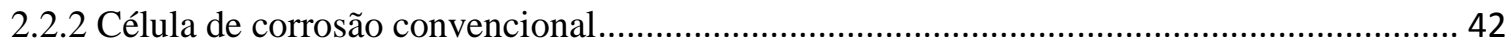

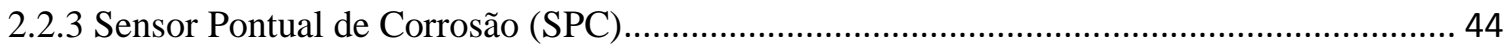

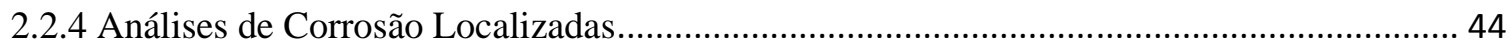

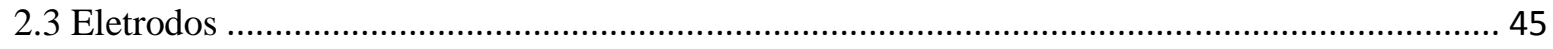

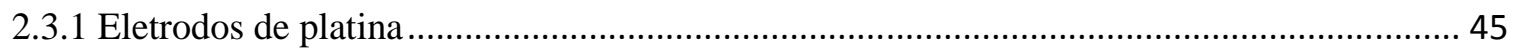

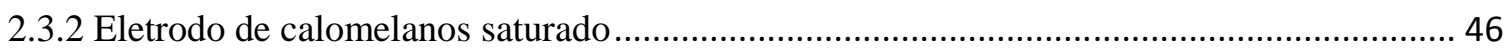

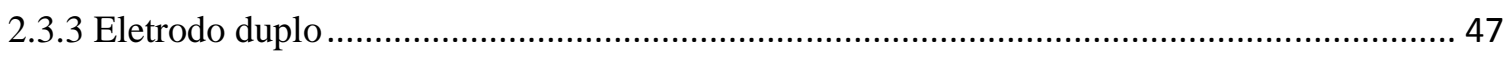

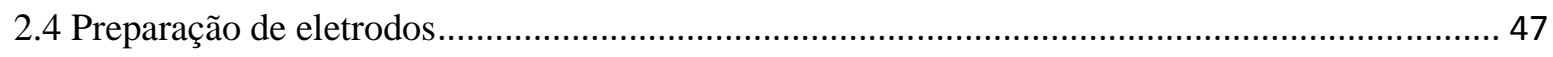

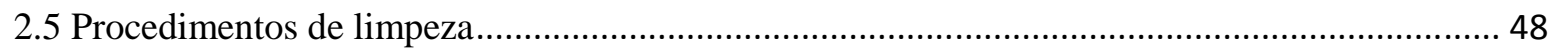

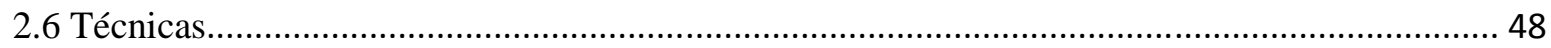

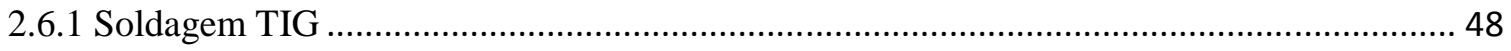

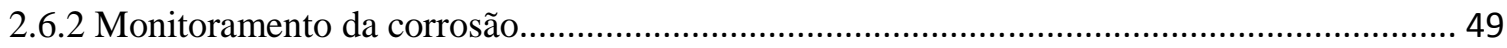


2.6.2.1 Análises globais 49

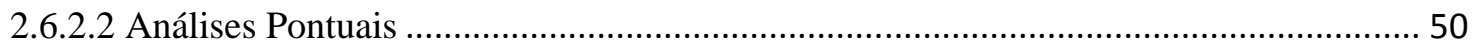

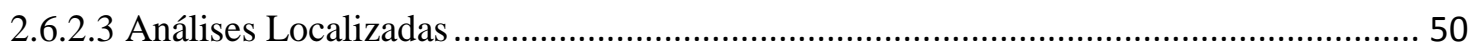

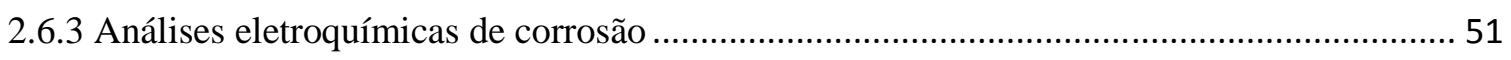

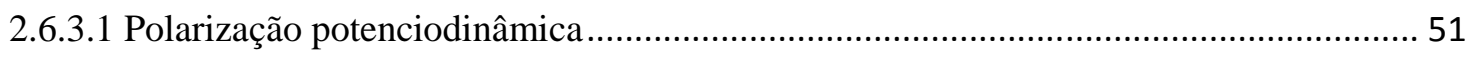

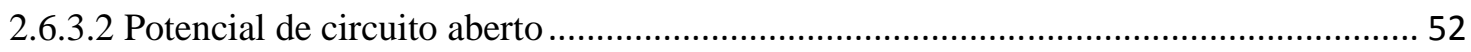

2.6.3.3 Resistencia de polarização...................................................................................... 53

2.6.3.4 Espectroscopia de Impedância Eletroquímica................................................................... 53

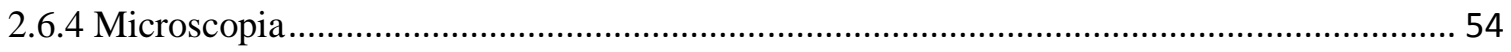

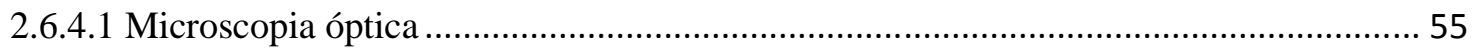

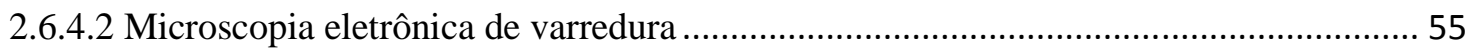

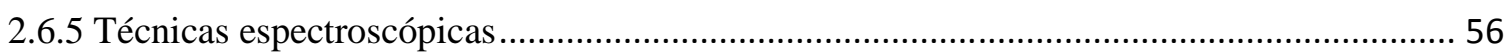

2.6.5.1 Espectroscopia de energia dispersiva de raios X....................................................... 56

2.6.5.2 Espectroscopia na região do infravermelho por transformada de Fourrier .................... 57

2.6.5.3 Espectroscopia na região do ultravioleta-visível ........................................................ 58

2.6.6 Ensaios de corrosão acelerados: câmara de névoa salina.................................................... 58

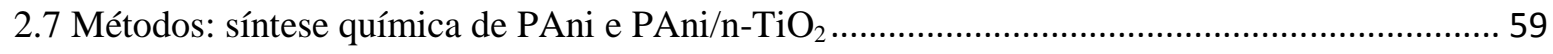

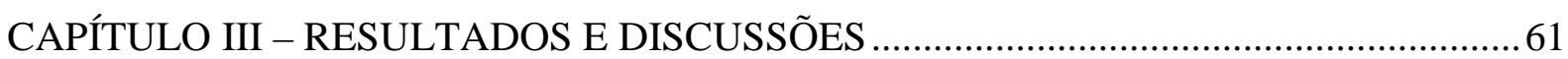

3.1 Caracterização da influência da aplicação de solda em aços inoxidáveis e carbono e efeito do recobrimento de PAni na proteção contra a corrosão................................................................... 61

3.1.1 Caracterização metalográfica de soldas em aços inoxidáveis 304 e 316 ............................. 61

3.1.2 Caracterização metalográfica de soldas no aço carbono 1020 ............................................ 65

3.1.3 Sensor pontual de corrosão: comparação com a célula convencional ...................................67

3.1.4 Influência da corrente de solda na corrosão de aços inoxidáveis ........................................... 71

3.1.5 Aplicação de revestimento protetor de PAni para proteção contra a corrosão de soldas dos

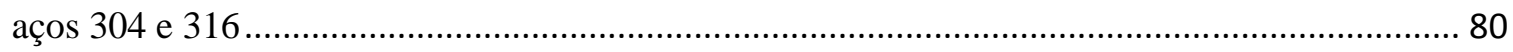

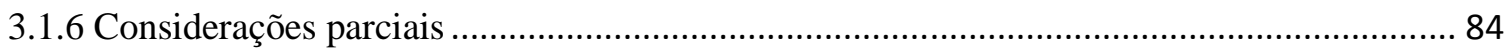

3.2 Estudos eletroquímicos globais e localizados da influência da solda TIG na corrosão do aço

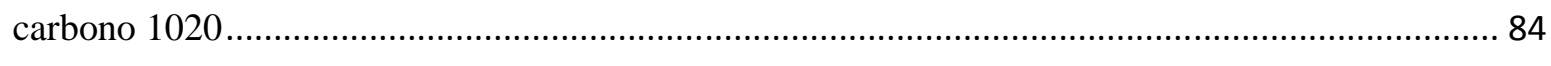

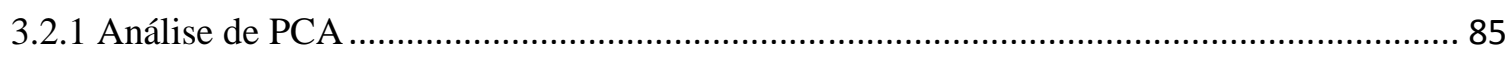

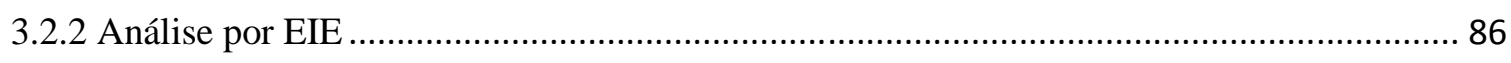

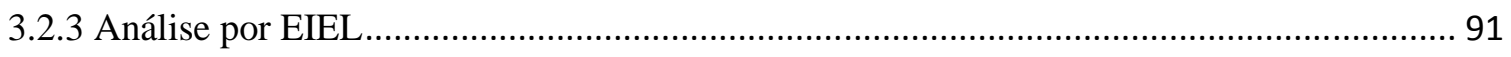

3.2.4 Análises pela técnica do eletrodo vibratório de varredura ................................................. 95

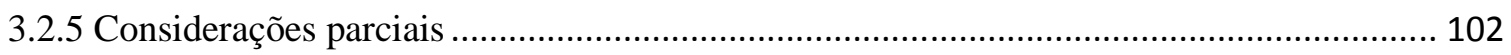


3.3 Síntese, caracterização e aplicação de $\mathrm{PAni} / \mathrm{TiO}_{2}$ como revestimento protetor contra a corrosão do aço carbono 1020 em meio de cloreto.

3.3.1 Estudos preliminares de revestimentos a base de PAni e PAni/ $/ \mathrm{TiO}_{2} \ldots \ldots \ldots \ldots \ldots \ldots \ldots \ldots \ldots \ldots \ldots . . . . . . . . . . . . . . .103$

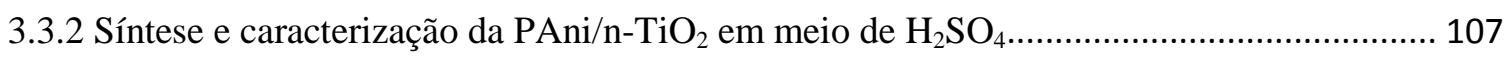

3.3.3 Recobrimento de aço carbono 1020 com revestimentos de PAni e PAni/n- $\mathrm{TiO}_{2}$.............. 117

3.3.4 Influência do número de camadas no desempenho de revestimentos PAni e PAni/n- $-\mathrm{TiO}_{2} 125$

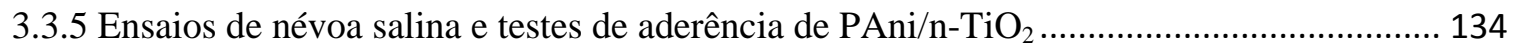

3.3.6 Aplicação de 3 camadas de $\mathrm{PAni} / \mathrm{n}-\mathrm{TiO}_{2}$ em solda de aço carbono.................................. 137

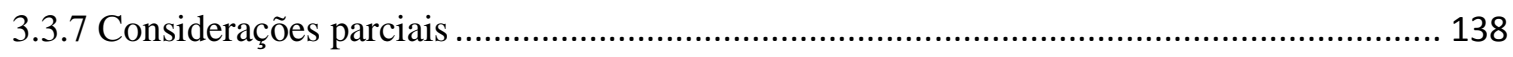

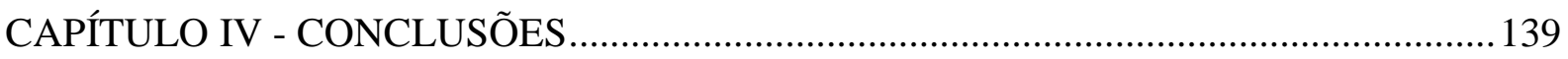

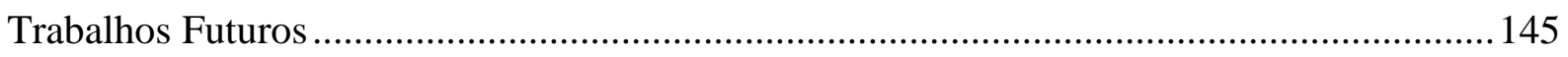

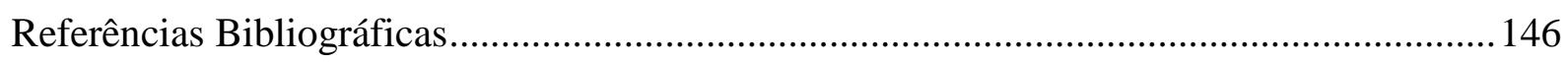




\section{CAPÍTULO I}

\section{INTRODUÇÃO}

\subsection{Aspectos gerais sobre a corrosão}

Em uma definição simples e bem aceita no meio científico, a corrosão é o processo de deterioração de um material, por meio químico ou eletroquímico, associado ou não a esforços mecânicos. Embora alguns autores considerem que mudanças em propriedades físicas ou químicas de materiais como a borracha e a madeira configurem corrosão, são os metais e suas ligas os materiais que estão no centro desta área de estudo. Os gastos de um país desenvolvido neste setor (segundo o "Institute of Corrosion", no Reino Unido) giram em torno de 3,5\% do seu PIB [1]. Embora este dado seja uma estimativa (uma vez que não é possível calcular com exatidão estes gastos), ele mostra a importância em fazer pesquisas nesta área de estudo.

Alguns autores consideram a corrosão de metais como um processo inverso ao processo metalúrgico (usado para extração de metais da natureza), uma vez que a energia utilizada para extrair os metais em sua forma mineral é a mesma liberada na reação química na corrosão. No processo corrosivo, o metal retorna a um estado de composto químico, similar ou às vezes idêntico ao mineral do qual foi extraído. Como exemplo, pode-se citar o ferro, que em geral é encontrado na forma hematita, $\mathrm{Fe}_{2} \mathrm{O}_{3}$. Quando hidratado, este óxido é conhecido como ferrugem $\left(\mathrm{Fe}_{2} \mathrm{O}_{3} \cdot \mathrm{xH}_{2} \mathrm{O}\right)$ [2].

Encontramos um grande número de exemplos de estruturas construídas a partir de metais e suas ligas. Elas podem ser visíveis, como as linhas de transmissão de energia elétrica, pontes, viadutos, meios de transportes (carros, ônibus, aviões, trens, etc), reatores, trocadores de calor, etc. Outras estruturas, igualmente importantes, se encontram enterradas no solo, como oleodutos, gasodutos, tanques de armazenamento de combustíveis, cabos de comunicação, etc. Esta quantidade de aplicações justifica os altos investimentos para garantir a integridade das estruturas metálicas, conferindo a estas durabilidade, e protegendo-as contra os processos de corrosão, com o objetivo de evitar acidentes que resultem em danos materiais ou perdas pessoais irreparáveis [3]. Praticamente todos os ambientes, em algum grau, são corrosíveis, devido à presença dos compostos que provocam a este processo. No ar encontramos sulfetos, amônia, cloreto, sulfato e nitrato de hidrogênio, além dos gases combustíveis. Na água existem os ácidos inorgânicos (ácido clorídrico, sulfúrico, etc.) e inorgânicos (ácidos acético, fórmico, etc.), além de sais, principalmente os que contêm cloreto. Ainda que a corrosão ocorra com maior frequência em presença de água, este 
processo também pode ocorrer em ambientes secos devido aos gases emitidos por caldeiras e processos de produção de indústrias, e pode ser ainda mais pronunciado em condições de elevadas temperatura e pressão [4].

No caso dos metais, o grau de corrosão depende de vários fatores: características físico-químicas (como composição química, tratamentos térmicos e mecânicos, presença de soldas, contato com outros metais), meio em que está inserido (composição química, pH, temperatura, grau de aeração) e condições operacionais (solicitação mecânica, meios de proteção existentes e condição de imersão - total ou parcial). A corrosão em metais ocorre por um processo eletroquímico de oxi-redução. A reação de oxidação provoca a dissolução inicial do metal (eq. 1) que, em presença de íons hidroxila, pode formar um hidróxido insolúvel (eq. 2).

$$
\begin{aligned}
& \mathrm{M}_{(\mathrm{s})} \rightarrow \mathrm{M}^{\mathrm{x}+}(\mathrm{aq})+\mathrm{xe}^{-} \\
& \mathrm{M}^{\mathrm{x}+}{ }_{(\mathrm{aq})}+\mathrm{nOH}_{(\mathrm{aq})}^{-} \rightarrow \mathrm{M}(\mathrm{OH})_{\mathrm{n}}
\end{aligned}
$$

A reação de redução dependerá de fatores como meio em que a corrosão está ocorrendo ( $\mathrm{pH}$, em presença ou ausência de $\mathrm{O}_{2}$, etc.) e potencial eletroquímico do metal (eq. 3 a 6).

$$
\begin{aligned}
& \mathrm{H}_{2} \mathrm{O}+1 / 2 \mathrm{O}_{2(\mathrm{~g})}+2 \mathrm{e}^{-} \rightarrow 2 \mathrm{OH}_{(\mathrm{aq})}^{-} \\
& 2 \mathrm{H}_{2} \mathrm{O}+\mathrm{O}_{2(\mathrm{~g})}+4 \mathrm{e}^{-} \rightarrow 4 \mathrm{OH}_{(\mathrm{aq})}^{-} \\
& \mathrm{H}_{2} \mathrm{O}+2 \mathrm{e}^{-} \rightarrow \mathrm{H}_{2(\mathrm{~g})}+2 \mathrm{OH}_{(\mathrm{aq})}^{-} \\
& 2 \mathrm{H}^{+}{ }_{(\mathrm{aq})}+2 \mathrm{e}^{-} \rightarrow \mathrm{H}_{2(\mathrm{~g})}
\end{aligned}
$$

Quando um metal é imerso em uma solução contendo seus íons, um potencial termodinâmico é estabelecido entre este metal e a solução. Se uma corrente atravessa o metal, o potencial se altera em função desta corrente, provocando um fenômeno chamado polarização. A diferença entre o novo potencial e o potencial de equilíbrio é chamado sobrepotencial, $\eta$ (eq. 7).

$\eta=\mathrm{E}-\mathrm{E}_{\mathrm{eq}}$

Em um eletrodo polarizado, a velocidade da reação fica limitada por algum tipo de processo, como transporte de massa (difusão, migração ou convecção), transporte de carga (transferência de elétrons) e adsorção ou dessorção de espécies sobre a superfície do eletrodo; nessas condições, a corrente permanece constante. À medida que a corrosão ocorre, a concentração de cátions do metal $\left(\mathrm{M}^{+\mathrm{n}}\right)$ aumenta na interface metal-solução, resultando em um maior número de espécies iônicas que precisa ser transportado pela difusão; quando a velocidade de reação é limitada pelo transporte destas espécies (difusão), ocorre a polarização 
por concentração $\left(\eta_{\text {conc }}\right)$. Já na polarização por ativação $\left(\eta_{\text {ativ }}\right)$ observa-se a formação de uma barreira energética à transferência de elétrons (transporte de cargas). Utilizam-se, para descrever este processo, as relações que foram verificadas empiricamente por Tafel, que utilizou analogias às equações de Butler-Volmer (que descreve a relação entre corrente e sobretensão de ativação) [3, 5]. Estas equações descrevem as polarizações anódica (eq. 8) e catódica (eq. 9) tem-se que:

$\eta_{\mathrm{a}}=\mathrm{a}_{\mathrm{a}}+\mathrm{b}_{\mathrm{a}} \log \mathrm{i}_{\mathrm{a}}$

onde: $a_{a}=(-2,3 R T / \beta n F) \log j_{\text {corr }}$ e $b_{a}=2,3 \mathrm{RT} / \beta n F$.

Para a polarização catódica, tem-se:

$\eta_{\mathrm{c}}=\mathrm{a}_{\mathrm{c}}-\mathrm{b}_{\mathrm{c}} \log \mathrm{i}_{\mathrm{c}}$

onde: $a_{c}=(2,3 R T /(1-\beta) n F) \log j_{\text {corr }}$ e $b_{a}=2,3 R T /(1-\beta) n F$.

$\mathrm{R}=$ constante dos gases.

$\mathrm{T}=$ temperatura.

$\beta=$ coeficiente de transferência.

$\mathrm{n}=$ número de oxidação da espécie eletroativa.

$\mathrm{F}=$ constante de Faraday.

$\mathrm{i}=$ densidade de corrente medida.

$\mathrm{j}_{\text {corr }}=$ densidade de corrente de corrosão.

Os tipos de corrosão mais comuns que podem ocorrer são corrosão uniforme, galvânica, por placas, alveolar, puntiforme (ou por pite), intergranular, trasngranular, esfoliação, e empolamento por hidrogênio, dentre outros (Fig. 1). Dentre estas, a corrosão puntiforme é uma das formas mais agressivas de corrosão; apresenta-se como pequenos pontos sobre a superfície do metal, possuindo, em geral, profundidade maior que o seu diâmetro. Difere, por exemplo, da corrosão uniforme, em que ocorre corrosão em toda extensão da superfície, e uma perda homogênea da espessura. Embora a quantidade de metal dissolvido na corrosão por pites seja menor que na corrosão uniforme, por exemplo, a corrosão puntiforme é muito perigosa porque, por ser muito localizada, não pode ser detectada por simples inspeção visual, e o ataque se estende pelo interior do metal. Por isso, a corrosão pontual compromete a resistência mecânica dos metais, expondo-os a riscos de ruptura. 


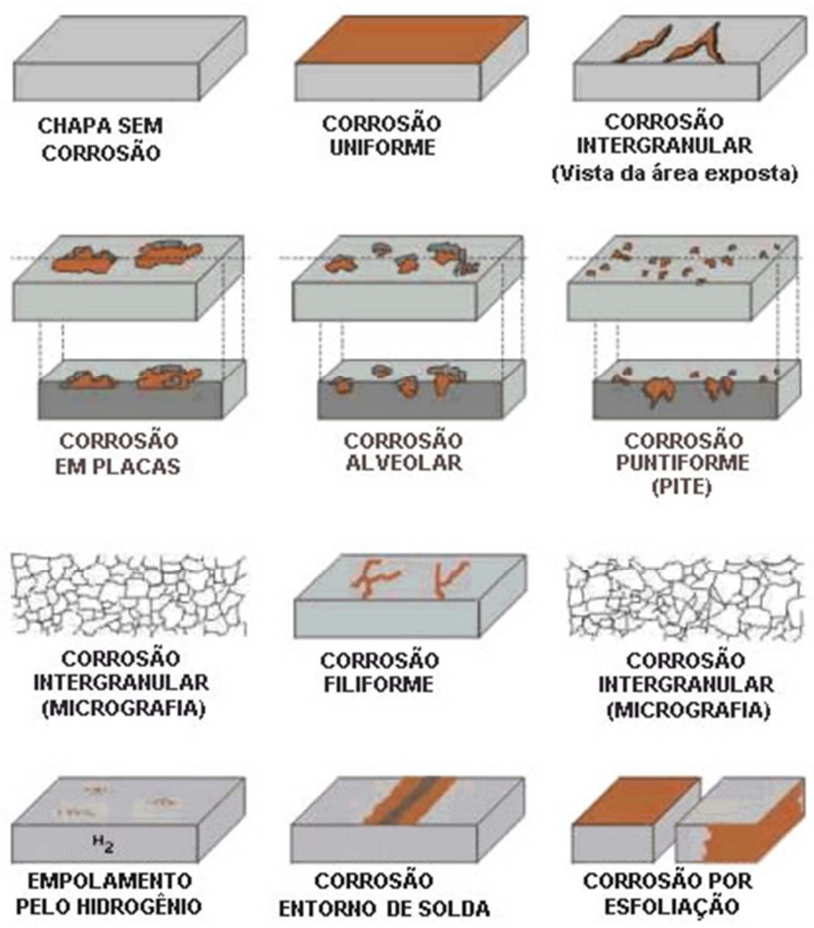

Figura 1 - Diferentes formas de corrosão [6].

A corrosão por pites é mais frequentemente observada em metais reativos que possuem a propriedade de formação de um filme passivador; este filme se forma pela oxidação do próprio metal (como ocorre, por exemplo, com o alumínio e o cobre) ou algum elemento de liga com esta propriedade (como o cromo, presente como elemento de liga nos aços inoxidáveis).

O filme de passivação é constituído por óxidos e/ou hidróxidos por reação do cátion metálico, resultando em um filme fino e aderente. A formação desta camada não depende somente do metal, mas também do meio em que ele está inserido. Assim, por exemplo, metais como ferro, níquel e aços se passivam em soluções fortemente ácidas, enquanto que alumínio e cobre se passivam em soluções ácidas mais diluídas. Se metais como ferro, níquel ou aços forem colocados em meios ácidos mais diluídos, eles sofrerão corrosão. O mesmo ocorrerá com o alumínio e o cobre, caso sejam colocados em algum meio fortemente ácido.

Para que a corrosão puntiforme ocorra, é necessário que ânions agressivos (como $\mathrm{Cl}^{-}$, $\mathrm{SO}_{4}{ }^{2-} \mathrm{e} \mathrm{ClO}_{4}{ }^{-}$) estejam presentes no meio; estes ânions penetram pela camada de passivação, dando início à corrosão. Esta entrada dos íons pela camada de passivação se torna possível porque uma diferença de potencial se estabelece entre as interfaces metal/filme passivador e filme passivador/eletrólito. Adicionalmente, a alta quantidade de defeitos e a estrutura desordenada do filme (em geral, amorfa) facilitam a entrada destes íons. Entretanto, ainda não é totalmente compreendido o fato de que, embora as irregularidades sejam observadas ao 


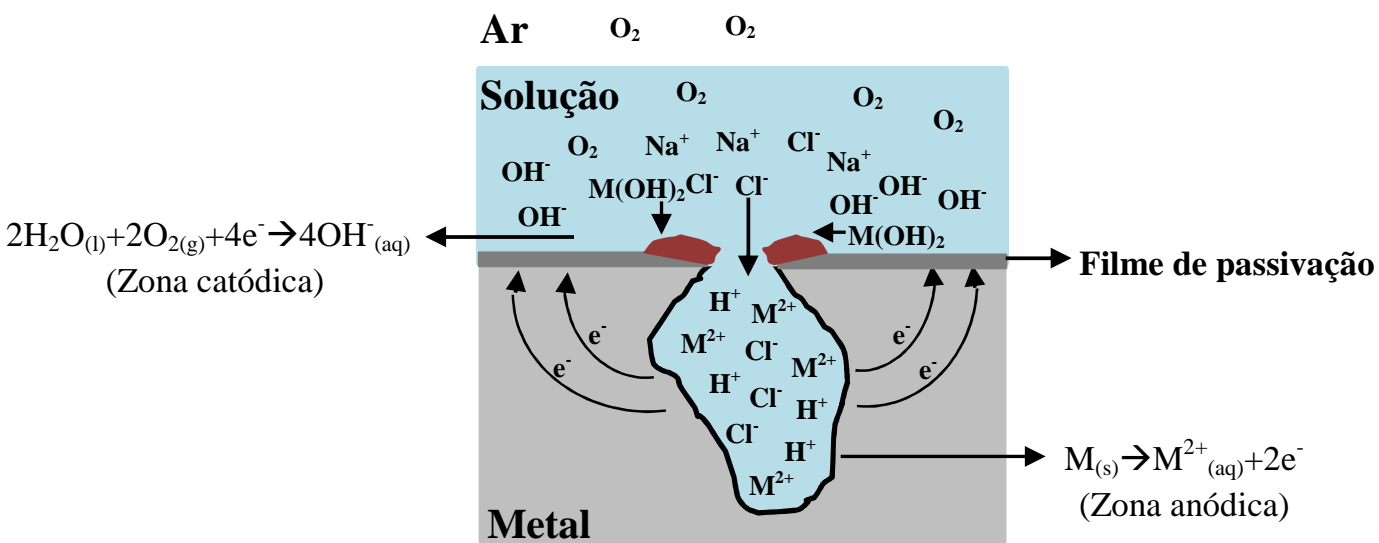

Figura 2 - Mecanismo de formação do pite por ação do $\mathrm{Cl}^{-}$em metais que possuem óxido passivador [8].

longo de todo filme, a entrada de íons ocorre somente de forma localizada [7]. A corrosão por pites inicia-se por, pelo menos, um dos seguintes mecanismos: penetração do íon pelo filme passivador, quebra do filme pelo íon ou adsorção do íon sobre a camada passivadora. Entretanto, dois ou os três mecanismos podem estar associados em um dado processo [7].

Um dos mecanismos propostos para este tipo de corrosão propõe que o processo inicia-se com o rompimento da camada de passivação pelo íon $\mathrm{Cl}^{-}$; como este rompimento ocorre de forma localizada, o metal é parcialmente exposto à solução. Em meio aquoso aerado neutro, esta região exposta sofre oxidação por dissolução do metal e redução do $\mathrm{O}_{2}$ (eq. 10 e $11)$.

$$
\begin{aligned}
& \mathrm{M}_{(\mathrm{s})} \rightarrow \mathrm{M}^{2+}{ }_{(\mathrm{aq})}+2 \mathrm{e}^{-} \\
& 2 \mathrm{H}_{2} \mathrm{O}_{(\mathrm{l})}+\mathrm{O}_{2(\mathrm{~g})}+4 \mathrm{e}^{-} \rightarrow 4 \mathrm{OH}^{-}(\mathrm{aq})
\end{aligned}
$$

Na região anódica ocorre a corrosão e formação do pite, e ao redor desta está localizada a área catódica (Fig. 2). Assim, a região onde o pite está se formando fica, localmente, positivamente carregada. Para manter a eletroneutralidade local, esta carga positiva é contrabalanceada por íons $\mathrm{Cl}^{-}$(pois eles têm maior mobilidade que os íons $\mathrm{OH}^{-}$). Os cátions $\mathrm{M}^{2+}$ sofrem hidrólise com a $\mathrm{H}_{2} \mathrm{O}$, formando o hidróxido insolúvel $\mathrm{M}(\mathrm{OH})_{2}$ e deixando o meio localmente ácido (eq. 12).

$$
\mathrm{M}^{2+}{ }_{(\mathrm{aq})}+2 \mathrm{H}_{2} \mathrm{O} \rightarrow \mathrm{M}(\mathrm{OH})_{2(\mathrm{~s})}+2 \mathrm{H}^{+}{ }_{(\mathrm{aq})}
$$

Em meio levemente ácido o hidróxido de ferro é solúvel; assim, esta camada de hidróxido é removida, expondo o metal ao qual ele estava aderido. Este metal exposto sofre oxidação, e por meio deste mecanismo o pite aumenta sua profundidade; assim, por meio deste mecanismo auto-catalítico ocorre o crescimento do pite. Embora esta forma de corrosão possa ocorrer em qualquer superfície metálica, é mais frequentemente observado em metais 
que se passivam, uma vez que a alta resistência da camada passivadora contribui para uma corrosão pontual $[5,8]$.

Embora ataques pontuais sejam mais comuns em metais que se passivam, também é possível que isto ocorra em metais que não possuem esta característica; é o caso dos aços carbono que possuem $\mathrm{S}$ e Mn em sua composição. Em meio com alta concentração de $\mathrm{Cl}^{-}$ ocorre um ataque anódico nas regiões da superfície do metal que contêm S e Mn, iniciando o ataque localizado pela presença de sulfetos de ferro e manganês. $\mathrm{O}$ ataque localizado nas regiões contendo inclusões de sulfetos é atribuído pela baixa adesão do metal ao sulfeto [9].

\subsection{Processos de união dos materiais}

Os processos de união dos materiais são de grande importância tanto na construção de estruturas, quanto na manutenção das mesmas, pois por meio das inúmeras combinações de peças com diferentes formas e tamanhos, é possível obter desde pequenas até as maiores e mais complexas estruturas (como plataformas submarinas e naves espaciais). $\mathrm{O}$ processo utilizado para unir dois materiais deve ser decidido levando-se em conta as propriedades desejadas para os materiais unidos, aliada ao menor custo possível; assim, diversas tecnologias existem com o objetivo de promover a união íntima entre os materiais. Embora o desenvolvimento dos processos de união dos materiais que se tem hoje teve maior impulso somente no final do século XIX, há indícios de que estes processos já eram aplicados há cerca de 4800 anos atrás, nos vales dos rios Nilo e Tigres-Eufrates. A união entre dois materiais poderia ser feita, em teoria, simplesmente pela aproximação entre os mesmos, caso a distância atômica entre as duas partes fosse suficiente para haver atração entre os átomos, resultando na união dos materiais como uma espécie de solda espontânea. Esta condição seria possível se a união das partes metálicas fosse feita em vácuo absoluto, e se a pressão aplicada sobre as peças fosse suficientemente grande para deformar plasticamente a rugosidade superficial, até que as partes tivessem íntimo contato, formando uma solda. Entretanto, na prática isto não é factível porque seria necessário que as superfícies fossem completamente planas a nível atômico e não poderia existir nenhuma camada entre estas duas superfícies (como óxidos ou gás adsorvido) [10].

As técnicas de união dos materiais se dividem em dois grupos. O primeiro grupo compreende os processos de fixação, que são aqueles em que os materiais são unidos apenas fisicamente; o segundo grupo compreende os processos em que há formação de uma ligação entre as partes, como os processos de colagem (por meio de adesivos), brasagem, solda branda e a soldagem. 
O processo de colagem consiste simplesmente no uso de um fluido, em geral muito viscoso, para manter duas partes unidas. Possui variados custos, e, em geral, não provoca alterações estruturais e de fases cristalinas no metal. As partes são unidas pelas forças de tensão superficial ou pela interação mecânica do adesivo com as irregularidades das superfícies metálicas (picos e vales, característicos da rugosidade do metal); para que possa ser utilizado, as superfícies do metal precisam estar totalmente limpas. Propriedades físicas como energia superficial do metal precisam ser consideradas, pois é necessário que o adesivo aplicado "molhe" a superfície [11].

A fixação é o processo de união física de dois materiais a partir do uso de um fixador, sem que haja aplicação de calor aos materiais e; por consequência, não há alterações estruturais nos mesmos. Os fixadores possuem uma diversidade de tamanhos e formas, como, por exemplo, os parafusos, pregos, rebites e grampos. Dentre as vantagens deste método, ele pode ser aplicado a praticamente qualquer tipo de material, resultando em um processo de união temporário ou semipermanente, de forma que a estrutura pode ser desmontada. $\mathrm{O}$ processo possui baixo custo, e, em geral, não exige procedimentos específicos para avaliar a aplicabilidade dos fixadores. Por outro lado, o processo de fixação não produz vedação hermética, envolve várias operações distintas (confecção do fixador, furação das partes a serem unidas e inserção do fixador nos furos) e pode ocorrer afrouxamento pela vibração e corrosão do material.

O processo de brasagem se caracteriza pela utilização de um material fundido para unir duas partes de um material, os quais permanecem na fase sólida. O material adicionado deve possuir temperatura de fusão superior a $450^{\circ} \mathrm{C}$, porém inferior à temperatura de fusão do material base (material a ser unido). Este método não é empregado em grandes peças ou estruturas porque exige maior limpeza superficial, além de dificuldades para se obter uniões com as propriedades mecânicas e metalúrgicas desejadas. A solda branda é um processo semelhante à brasagem, diferenciando-se somente pelo fato que o material a ser adicionado deve possuir ponto de fusão abaixo de $450^{\circ} \mathrm{C}$, enquanto os materiais base permanecerão no estado sólido. É muito utilizado na união de circuitos em eletro eletrônica, onde altas propriedades mecânicas não são de fundamental importância [10].

\subsubsection{União por solda}

O processo de soldagem é o método mais utilizado para unir materiais. A união pode ser feita por três maneiras: fusão dos metais em íntimo contato entre si, fusão dos metais e adição de outro material fundido, ou simplesmente pelo contato destes materiais na fase sólida 
ou semi sólida. Embora a soldagem provoque maiores alterações no material base, o processo apresenta grande versatilidade, economia e resulta em uniões com excelentes propriedades mecânicas.

Tecnicamente, soldagem é o processo utilizado para unir duas partes metálicas usando uma fonte de calor; a solda é o resultado deste processo. Ainda, em outra definição, soldagem é uma coalescência localizada de metais ou não metais, provocada pelo aquecimento dos materiais até a temperatura de soldagem, com ou sem a aplicação de pressão; ou ainda somente pela aplicação de pressão, com ou sem o uso de metal de adição [10]. É considerada uma forma segura e eficiente para unir metais, por isso é amplamente usada na indústria.

O período de grande desenvolvimento desta área foi durante a II Guerra Mundial, na construção de navios e aviões, e atualmente é utilizada para a construção de uma grande gama de produtos e estruturas, como aeronaves, veículos espaciais, navios, transportes ferroviários e rodoviários, pontes, prédios, oleodutos, plataformas marítimas e componentes eletrônicos, só para citar alguns exemplos. O sucesso de um processo de soldagem requer alguns cuidados: uma quantidade de energia suficiente para unir os metais em questão deve ser gerada, a contaminação das superfícies deve ser removida, o contato da região de soldagem com o ar atmosférico deve ser evitado e deve haver controle da metalurgia de soldagem, alcançando-se, assim, as propriedades físicas, químicas e mecânicas desejadas.

Os processos de soldagem podem ser classificados pelo tipo de fonte de energia, que podem ser mecânica, química, radiante ou elétrica. Nas fontes elétricas, o calor é gerado pela passagem de corrente elétrica (efeito Joule) ou pela formação de um arco elétrico. Um arco elétrico é uma descarga elétrica (de baixa tensão e alta intensidade) que passa através de um gás ionizado, iniciada por uma quantidade de elétrons emitidos do eletrodo negativo (cátodo) e mantido pela ionização térmica do gás aquecido.

É necessário o conhecimento e controle sobre as variáveis elétricas e operacionais em soldagens; a mais importante é a corrente de solda, pois é ela que controla diretamente a magnitude e a distribuição da energia térmica contida no arco elétrico, determinando a penetração da solda e a largura do cordão; assim, correntes muito altas, por exemplo, podem aquecer excessivamente um revestimento e degradá-lo.

As condições de resfriamento também são importantes, pois velocidades de resfriamento excessivamente altas ou baixas são indesejáveis. Outra variável importante é a velocidade de avanço da soldagem, pois combinada com a intensidade da corrente, determina a altura (penetração) e largura do cordão (é uma variável mais difícil de ser controlada rigorosamente em soldas aplicadas manualmente). Outras variáveis que interferem no 
processo são: oscilação do eletrodo (e, consequentemente, do arco), dimensões do eletrodo e ângulo de contato do eletrodo em relação à peça [12].

Durante o processo térmico de soldagem, uma região relativamente estreita do material fica sujeita a uma ampla faixa de picos de temperatura e taxas de resfriamento, resultando em uma variedade de microestruturas e mudanças nas propriedades da área afetada. Processos de soldagem causam estresse residual e modificações metalúrgicas. Além disso, a diferença da estrutura cristalina entre o metal base (aquele que não sofreu nenhuma alteração pelo processo de solda) e o metal soldado pode causar corrosão galvânica [13].

\subsubsection{Soldagem TIG}

No processo de soldagem denominado TIG (Tungsten Inert Gas), também conhecido como GTAW (Gas Tungsten Arc Welding), um arco pequeno e estável é mantido entre um eletrodo não consumível de tungstênio e o material a ser soldado (fonte de calor); um fluxo de gás inerte (argônio ou hélio) garante a proteção da região de solda. $O$ gás inerte tem a função de proteger a região que está sendo soldada contra os gases que existem na atmosfera, os quais podem prejudicar as propriedades do metal durante o processo de soldagem. Para aços carbono, por exemplo, o nitrogênio e oxigênio diminuem a resistência mecânica; para aços inoxidáveis, o nitrogênio diminui a porcentagem de fase ferrita e promove rachaduras por solidificação [14].

As soldagens tipo TIG produzem soldas de alta qualidade, e podem ser usadas para a maioria dos metais e suas ligas (alumínio, magnésio, titânio e aços inox e de baixa liga). Possuem fonte de calor concentrada (utilizam uma fonte de energia de corrente constante), minimizando a extensão da zona termicamente afetada, e permite uma faixa de corrente de trabalho entre 10 a 400 A [12]. Os processos de soldagem, em geral, reduzem a quantidade do material devido à fusão do mesmo; por isso, um metal de enchimento pode ser usado para compensar esta perda.

Além da zona de solda, observam-se também outras duas zonas que sofrem modificações: a zona parcialmente fundida e a zona afetada pelo calor, além, do metal base (Fig. 3). As alterações nas fases cristalinas contidas nessas regiões dependerão da quantidade de carbono no aço e da temperatura da solda [14]. A zona parcialmente fundida está imediatamente adjacente à zona de fusão; já a região afetada pelo calor sofre os efeitos da condução do calor da zona de fusão, o qual não é grande o bastante para provocar a fusão do material, mas suficiente para causar alterações significativas nas suas propriedades e microestrutura. Isto resulta na perda de sua força mecânica e resistência à corrosão [14]. 


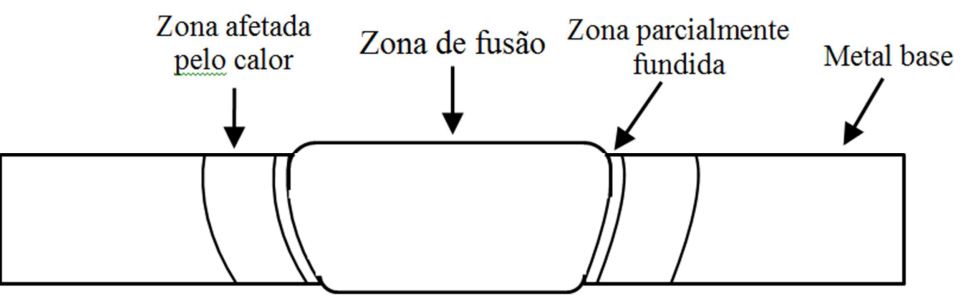

Figura 3 - Diferentes zonas presentes na região de solda [14].

\subsubsection{Zona afetada pelo Calor}

A zona afetada pelo calor (ZAC) é a região do metal imediatamente vizinha à zona de fusão. Diferentemente desta primeira região, a ZAC não sofre fusão, porém tem sua microestrutura alterada devido ao calor resultante dos ciclos térmicos do processo de soldagem, ou ainda por operações de corte. Diferentemente da zona de fusão, não se pode corrigir tais problemáticas pela simples alteração da composição química (utilizando um metal de enchimento diferente do metal base). A extensão desta região depende da difusividade térmica do metal (propriedade da velocidade com que o calor se difunde através metal); quando a difusividade térmica é alta, o calor se dissipa mais rapidamente, e a extensão da ZAC é pequena. Contudo, quando esta propriedade possui um valor baixo, o maior tempo de resfriamento faz com que a extensão resultante da ZAC seja maior.

Além do metal, a quantidade de calor aplicada ao material também influi na extensão desta região; variáveis como potencial aplicado, corrente utilizada e velocidade da soldagem determinam esta quantidade de calor aplicada. Frequentemente, esta região se constitui como uma zona de menor resistência mecânica, devido à sua estrutura granular menos resistente que o metal base, e mesmo que a zona bruta de fusão. A ZAC é subdividida ainda em diferentes regiões, em função dos diferentes gradientes de temperaturas alcançados: regiões de crescimento de grão, de grão, transformação parcial, esferoidização de carbonetos, além do metal base não afetado (Fig. 4).

O crescimento de grão ocorre adjacente à zona de fusão, à temperaturas entre 1100 à $1500{ }^{\circ} \mathrm{C}$, resultando em alteração da fase ferrita para austenita. Em geral, nesta região ocorre uma transformação plástica homogênea na austenita acelerando, através da recristalização primária, o crescimento de grão. O posterior crescimento do grão dependerá do tempo de permanência em temperatura acima de $1300^{\circ} \mathrm{C}$. A região de refino de grão ocorre entre temperaturas de 1100 e $900{ }^{\circ} \mathrm{C}$. 
Na região de crescimento de grão também ocorre uma deformação devido à alteração de fases, de ferrita para austenita, porém menor que a região anterior, devido à menor temperatura e tempo. A austenita obtida é recuperada antes de sua transformação, produzindo ferrita e/ou perlita (com pequeno tamanho de colonia). Esta região também apresenta elevadas resistência mecânica e ductibilidade. A região parcialmente transformada se forma entre temperaturas de 900 e $750{ }^{\circ} \mathrm{C}$. Durante o resfriamento, a austenita formada pode se decompor em perlita, bainita ou martensita meclada (martensita de alto teor de carbono); assim, esta região pode apresentar propriedades mecânicas piores que o metal base.

A última região da ZAC é denominada região de esferoidização de carbonetos, e ocorre entre 750 e $700{ }^{\circ} \mathrm{C}$. Nesta região, as lamelas de cementita da perlita podem se esferoidizar. A resistência mecânica nesta região diminui. Assim, o que se pode concluir é que a ZAC é uma zona complexa, composta por várias regiões com diferentes composições microestruturais, e que resultam em diferentes propriedades mecânicas.

O tipo de material utilizado influencia diretamente na qualidade da solda obtida. Por exemplo, baixa quantidade de carbono resulta em soldas com boa resistência mecânica, baixa susceptibilidade a rachaduras na zona termicamente afetada (ZTA) e resistência contra a corrosão. O manganês previne a fratura da solda, pois há formação de MnS ao invés de FeS; entretanto, mesmo com a presença deste elemento, altas concentrações de carbono na liga $(0,2-0,3 \%)$ não previnem a fratura na região de solda. Ocorre formação de uma fase martensítica (frágil), que resulta na fratura durante processo de solidificação da zona de fusão [12].

Um ponto desfavorável da soldagem TIG é possibilidade de segregação dos elementos de liga. Por exemplo, partículas de carbeto de cromo e de titânio podem se precipitar nos contornos de grãos (à temperaturas de $600-850^{\circ} \mathrm{C}$ e $1100^{\circ} \mathrm{C}$, respectivamente), causando uma segregação destes elementos na matriz da liga. Entretanto, para que ocorra precipitação destes elementos é necessário que o resfriamento seja lento, situação esta que ocorre na zona termicamente afetada (na zona de fusão o resfriamento é rápido, portanto não há tendência de ocorrer esta segregação). Por isso, esta é uma região muito susceptível à corrosão, devido à precipitação de elementos como o $\mathrm{Cr}$, que são responsáveis pela formação da camada de passivação. Ainda, assim como para aços carbono, o aumento da concentração de $\mathrm{C}$ em aços inoxidáveis resulta em soldas com piores características [14]. Embora a composição das soldas seja homogênea, ela difere do material base. As mudanças causadas pela fusão nesta região alteram a estrutura cristalina do metal, podendo gerar diferentes potenciais eletroquímicos em soluções e, consequentemente, processos de corrosão galvânica [15]. 


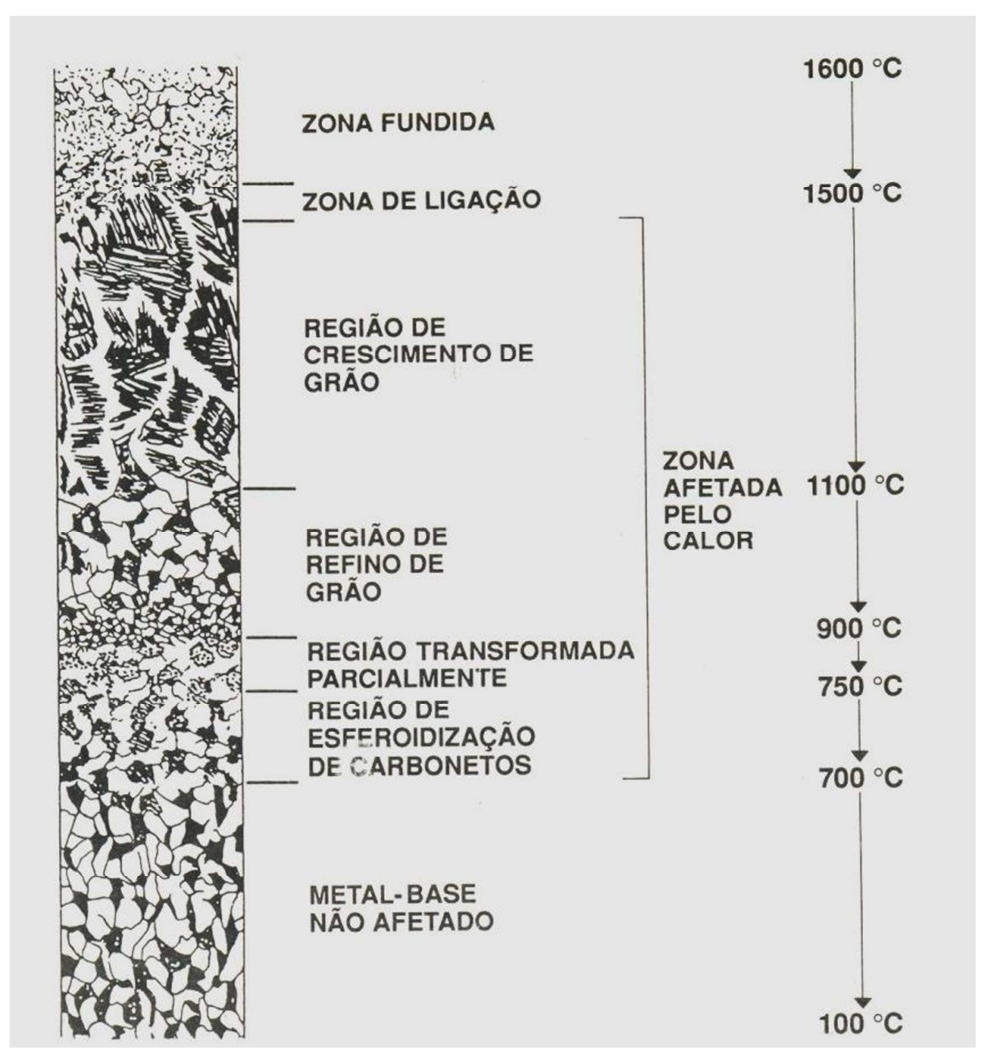

Figura 4 - Regiões da zona afetada pelo calor [12].

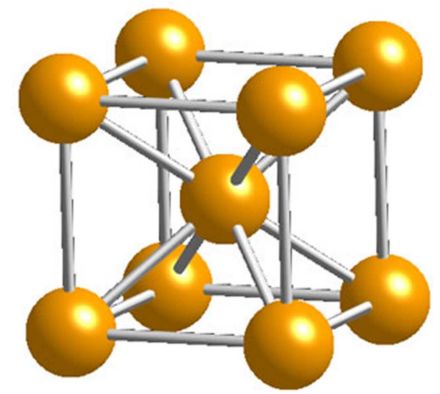

(a)

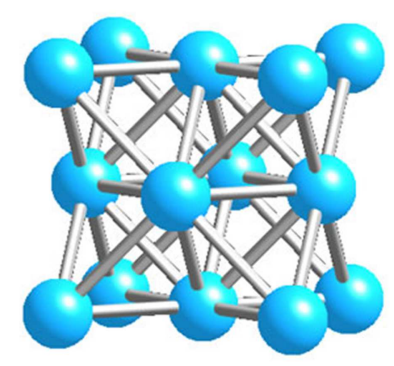

(b)

Figura 5 - Estruturas cristalinas: (a) cúbica de corpo centrado e (b) cúbica de face centrada [16].

A proporção das fases cristalinas determinam as propriedades físicas do metal e a possibilidade de ocorrer segregação durante a soldagem. A estrutura cúbica de corpo centrada (Fig. 5a, ferrita) permite mais facilmente a difusão pelo arranjo cristalino, já que é uma estrutura relativamente aberta. Já estrutura do tipo cúbica de face centrada (austenítica) possui um empacotamento mais fechado (Fig. 5b) e, por isso, dificultam mais a difusão de espécies. Os elementos de liga são agrupados como formadores de fase ferrita $(\mathrm{Cr}, \mathrm{Mb}$ e $\mathrm{Si})$ e de fase austenítica (Ni, C e Mn); desta forma, é possível determinar a proporção teórica entre $\mathrm{Cr}$ e $\mathrm{Ni}$ na liga, uma vez que para se obter uma boa solda é desejável manter a proporção de fase 
ferrita entre 5 e $10 \%$. Isto porque proporções desta fase maiores que 10\% (em volume) tendem a diminuir a resistência à corrosão, ductibilidade e resistência física do metal, e quantidades inferiores a $5 \%$ podem resultar em rachaduras durante o processo de solidificação.

A corrosão de aços e suas soldas, especialmente nos aços carbono, é um problema relevante e causa significativas perdas econômicas. A ruptura de encanamentos, por exemplo, é um caso frequente de corrosão e causa falha no abastecimento; as avarias provocadas pela corrosão nestes sistemas resultam em grandes prejuízos de materiais, poluição ambiental e desastres ecológicos. Por isso, diversas pesquisas sobre as propriedades físicas e químicas dos metais soldados, como suscetibilidade à corrosão, estresse residual e alterações micro estruturais, têm sido feitas a fim de formular estratégias para a prevenção da corrosão, ainda que o mecanismo envolvido na corrosão localizada em soldas não está totalmente claro [13].

\subsection{Formas de proteção contra a corrosão}

O processo de corrosão nos metais ocorre porque estes apresentam uma condição termodinâmica instável; para alcançarem uma condição estável, formam óxidos, hidróxidos e sais. O controle da corrosão deve ser determinado a partir do conhecimento prévio do seu mecanismo específico, o que depende de variáveis como o tipo de metal empregado (aço, alumínio, o tipo da liga), o meio em que ele está inserido (atmosfera, submerso em água, composição química de cada meio) e as possíveis solicitações mecânicas a que ele estará sujeito. Desta forma, a proteção contra a corrosão é um estudo que deve ser feito em paralelo com o tipo de corrosão que o material sofrerá, pois este conhecimento prévio determinará os meios mais eficientes de conseguir uma boa proteção [17].

Um processo de corrosão em um metal, se não puder ser eliminado, poderá, pelo menos, ter sua cinética diminuída, se estratégias corretas forem utilizadas. Diversos procedimentos podem ser empregados com esta finalidade: modificação do processo (projeto da estrutura, proteção catódica), modificação do meio corrosivo (desaeração do meio aquoso, adição de inibidores de corrosão), modificação do metal (adição de elementos de liga, aumento da pureza) ou adição de revestimentos protetores (revestimentos orgânicos, inorgânicos, metálicos ou óxidos protetores resultantes da oxidação do próprio metal). Evidentemente a aplicação de tais procedimentos não é viável em todas as situações, devendo cada caso ser analisado especificamente, levando-se em conta ainda os custos relativos à aplicação de um determinado método, a fim de que se tenha, efetivamente, uma relação custo benefício favorável [3]. 


\subsubsection{Proteção Catódica}

Este tipo de proteção contra a corrosão é muito usado para instalações metálicas submersas ou enterradas, como oleodutos, gasodutos e plataformas submarinas de prospecção e produção de petróleo, entre outros, e tem a vantagem de garantir boa proteção contra a corrosão a estruturas que não podem ser inspecionadas ou revestidas periodicamente.

A corrosão em estruturas metálicas ocorre pela formação de áreas anódicas e catódicas em superfícies metálicas em contato com um eletrólito. Diferenças de potenciais se estabelecem ao longo do metal devido às variações da composição química do mesmo, tensões internas e regiões de solda, as quais podem ser agravadas por heterogeneidades do meio. Proteger catodicamente significa eliminar todas as áreas anódicas do metal, fazendo com que ele tenha somente comportamento catódico. Os tipos de proteção catódica que existem são proteção catódica galvânica (ou por ânodos de sacrifício) e por corrente impressa (ou forçada).

Na proteção galvânica catódica, utiliza-se um metal com menor potencial de redução do que o metal a ser protegido (em geral, utiliza-se ligas de $\mathrm{Mg}, \mathrm{Al}$ ou $\mathrm{Zn}$ ), conferindo assim ao metal de sacrifício o caráter de ânodo e ao metal a ser protegido, o caráter de cátodo. $\mathrm{O}$ eletrodo anódico sofre dissolução pela oxidação do metal, conforme já equacionado anteriormente (eq. 10), e a reação catódica ocorre pela redução da $\mathrm{H}_{2} \mathrm{O}$ (eq. 13 e 14), em presença ou ausência de $\mathrm{O}_{2}$ :

$2 \mathrm{H}_{2} \mathrm{O}+2 \mathrm{e}^{-} \rightarrow 2 \mathrm{OH}_{(\mathrm{aq})}^{-}+\mathrm{H}_{2(\mathrm{~g})}$

$2 \mathrm{H}_{2} \mathrm{O}+\mathrm{O}_{2(\mathrm{~g})}+4 \mathrm{e}^{-} \rightarrow 4 \mathrm{OH}_{(\mathrm{aq})}^{-}$

Na proteção catódica por corrente impressa, uma fonte geradora de corrente elétrica contínua fornece o suprimento de elétrons necessário à estrutura metálica para evitar sua oxidação. Estas fontes possuem eletrodos anódicos inertes, como grafite, titânio e nióbio. As reações que ocorrem são oxidação da $\mathrm{H}_{2} \mathrm{O}$ no ânodo inerte (eq. 15) e redução da $\mathrm{H}_{2} \mathrm{O}$ no cátodo (eq. 16 e 17).

$$
\begin{aligned}
& 2 \mathrm{H}_{2} \mathrm{O} \rightarrow \mathrm{O}_{2(\mathrm{~g})}+4 \mathrm{H}^{+}{ }_{(\mathrm{aq})}+4 \mathrm{e}^{-} \\
& 2 \mathrm{H}_{2} \mathrm{O}+2 \mathrm{e}^{-} \rightarrow 2 \mathrm{OH}^{-}{ }_{(\mathrm{aq})}+\mathrm{H}_{2(\mathrm{~g})} \\
& 2 \mathrm{H}_{2} \mathrm{O}+\mathrm{O}_{2(\mathrm{~g})}+4 \mathrm{e}^{-} \rightarrow 4 \mathrm{OH}_{(\mathrm{aq})}^{-}
\end{aligned}
$$

A vantagem da proteção por corrente impressa é a possibilidade de variar a corrente aplicada, otimizando assim a eficiência da proteção em eletrólitos com diferentes resistividades. Por isso a proteção catódica por corrente impressa é muito utilizada na proteção de tubulações enterradas, onde a resistividade do eletrólito é alta. Já em aplicações 
em que esta limitação não ocorre, como píeres de atracação de navios e tubulações submersas, são utilizados ânodos de sacrifício de $\mathrm{Zn}$ ou $\mathrm{Al}$ (embora proteção por corrente impressa também possa ser utilizado neste caso) $[3,17]$.

\subsubsection{Proteção Anódica}

A proteção anódica pode ser aplicada a materiais que apresentam comportamento ativo/passivo, como alumínio e aços inoxidáveis. Neste tipo de proteção, uma corrente anódica é aplicada sobre o metal a ser protegido, provocando inicialmente uma dissolução do metal, formando uma camada passivadora aderente de óxido que passa a proteger a superfície metálica. A taxa de corrosão inicialmente observada diminui drasticamente com o tempo pelo aumento da resistência na interface metal solução (que passa a conter uma nova camada e, portanto, duas novas interfaces: metal/óxido e óxido/solução). É importante que o potencial seja controlado (para evitar dissolução progressiva do metal), e é desejável que uma pequena corrente mantenha o metal passivado (para tornar o processo economicamente viável).

A proteção anódica somente pode ser aplicada a metais com comportamento ativo/passivo, como os aços inox. Assim, aços carbono não podem ser protegidos contra a corrosão por este método. Diferentemente da proteção catódica, onde a corrente é a variável mais importante para garantir proteção ao sistema, na proteção anódica o potencial é a variável mais crítica $[3,18]$.

\subsubsection{Revestimentos metálicos}

Os revestimentos metálicos podem ser utilizados com diferentes funções: decorativa $(\mathrm{Au}, \mathrm{Ag}, \mathrm{Ni})$, resistência ao atrito ( $\mathrm{In}, \mathrm{Cu})$, endurecimento superficial $(\mathrm{Cr})$ e, evidentemente, resistência à corrosão $(\mathrm{Cr}, \mathrm{Ni}, \mathrm{Al}, \mathrm{Zn})$. Estes tipos de revestimentos agem pela formação de películas protetoras de óxidos e hidróxidos (Al, Cr, Ni e Zn), ou pela alta sobrevoltagem dos elementos utilizados como metais protetores ( $\mathrm{Sn}, \mathrm{Pb}, \mathrm{Zn}$ e $\mathrm{Cd}$ ). Estes revestimentos devem ter boa aderência ao metal que será protegido, principalmente aos que possuem maiores potenciais de redução, pois a presença de eletrólitos na interface dos metais provoca a formação de uma pilha galvânica. Isto resulta na dissolução do metal que deveria ser protegido, principalmente se a relação área anódica/área catódica for pequena. Por isso a superfície do metal deve estar isenta de imperfeições e perfeitamente limpa e seca.

As técnicas utilizadas para aplicação de revestimentos metálicos são: cladização (laminação a quente de chapas do metal e do revestimento por explosão ou soldagem), 
imersão a quente (imersão do metal em banho do metal de revestimento fundido), aspersão térmica (o metal é revestido por meio de um jato composto por finas partículas do metal de revestimento no estado fundido), eletrodeposição (o metal a ser protegido serve como cátodo de uma célula eletrolítica com um banho contendo um sal do metal de revestimento) e cementação (metal é colocado em tambor rotativo e aquecido a altas temperaturas ao passo que um jato de pó do metal de revestimento é direcionado ao material metálico) $[3,18]$.

\subsubsection{Revestimentos não-metálicos inorgânicos}

São revestimentos constituídos de compostos não metálicos inorgânicos depositados diretamente na superfície do metal. São exemplos desta classe de revestimentos os esmaltes vitrosos, cerâmicas, porcelanas, óxidos, carbetos, nitretos, boretos e silicietos. Esmaltes vitrosos (borossilicato de alumínio e sódio ou potássio) e vidros são utilizados para proteger metais de ambientes ácidos (exceto ácido fluorídrico), mas não resistem meios básicos. Para este último tipo de meio, são utilizados cimentos e porcelanas (quartzo e solução de silicato de $\mathrm{Na}$ ou $\mathrm{K}$ e fluorsilicato de $\mathrm{Na}$ ), os quais são resistentes a meios aquosos salinos. Os óxidos $\left(\mathrm{Al}_{2} \mathrm{O}_{3}, \mathrm{Cr}_{2} \mathrm{O}_{3}, \mathrm{ZrO}_{2}\right)$, carbetos $\left(\mathrm{TiC}\right.$ e $\left.\mathrm{B}_{4} \mathrm{C}\right)$, nitretos $(\mathrm{AlN}$ e $\mathrm{BN})$, boretos $\left(\mathrm{ZrB}_{2}\right.$ e $\left.\mathrm{TiB}_{2}\right)$ e silicietos $\left(\mathrm{NbSi}_{2}, \mathrm{WSi}_{2}\right.$ e $\left.\mathrm{MoSi}_{2}\right)$ são empregados para revestimentos resistentes à temperaturas elevadas.

Os processos usados para obtenção de revestimentos metálicos são anodização, cromatização e fosfatização. A anodização, usada muito frequentemente para o alumínio, é um método em que o material metálico é colocado como um ânodo, a fim de aumentar a espessura da camada de óxido formada pelo próprio metal. Para utilizar este método, o metal precisa apresentar comportamento ativo/passivo. A cromatização é o processo de revestimento de um metal, óxidos ou fosfatos em banhos contendo cromatos ou ácido crômico. É utilizado para metais como $\mathrm{Sn}, \mathrm{Cu}, \mathrm{Ag}, \mathrm{Fe}$, aços, dentre outros. A fosfatização, por fim, é o processo de aplicação de camadas de fosfato sobre materiais metálicos como $\mathrm{Fe}, \mathrm{Zn}$, $\mathrm{Al}, \mathrm{Cd}$ e $\mathrm{Mg}$. Entretanto, este tipo de revestimento não apresenta grande eficiência na proteção contra a corrosão se usado isoladamente. É necessária a aplicação de outro revestimento, como pintura, e a camada fosfática agirá no sentido de aumentar a aderência do segundo revestimento $[3,18]$. 


\subsubsection{Revestimentos não-metálicos orgânicos (tintas e polímeros)}

Dentre as técnicas de proteção contra a corrosão, a aplicação de tintas é a mais utilizada, devido, primeiramente, a sua favorável relação custo/benefício, boa proteção contra a corrosão, facilidade de aplicação e de manutenção. Assim, a aplicação destes revestimentos oferece, além da finalidade prática, a finalidade estética, impermeabilização da superfície, impede a incrustação de microrganismos marinhos em cascos de embarcações e regula o grau de absorção da luz dependendo da cor empregada, dentre outras características.

Diferentes formas de aplicação das tintas permitem obter filmes com boa homogeneidade e baixa rugosidade, inclusive em locais difíceis de pintar, como quinas e arestas. Em geral, uma pintura com fins anticorrosivos é composta por três tipos de camadas.

O primeiro tipo de camada é denominado primer ou tintas de fundo, e são as tintas que estão em contato direto com o metal. Possui maior quantidade de pigmentos, inclusive de pigmentos anticorrosivos, resultando em camadas mais rugosas. São as responsáveis pelo mecanismo de proteção contra a corrosão do metal e pela aderência de todo esquema de pintura do metal, já que está em contato direto com o substrato.

As tintas intermediárias (segunda camada) nem sempre são utilizadas; elas têm a função de aumentar a espessura do revestimento. Sua formulação possui alto teor de sólidos, aumentando assim a proteção por barreira do revestimento.

As tintas de acabamento, por fim, conferem o acabamento final (estético) à pintura, e a resistência química do revestimento, pois é a tinta que está em contato direto com o meio corrosivo. As tintas são constituídas por veículo fixo, pigmentos, solventes (veículo volátil) e aditivos. O veículo fixo é o responsável pela formação e continuidade da película de tinta, e pode ser óleos vegetais e resinas (alquídicas, acrílicas, epoxídicas e poliuretanas). Os solventes são substâncias puras responsáveis pela solubilização da resina e controle da viscosidade. Podem ser compostos por hidrocarbonetos alifáticos (nafta, aguarrás) ou aromáticos, ésteres, álcoois, cetonas, glicóis e solventes filmógenos (aqueles que, além de solubilizarem a resina, se incorporam à película por polimerização).

Os aditivos são compostos que têm a função de conferir propriedades específicas às tintas, como melhorar a secatividade das películas (secantes), evitar a formação de espumas (antiespumantes), conferir ou aumentar a flexibilidade do filme (plastificantes), prevenir a deterioração por fungos e bactérias (antifungos), dentre outros. 


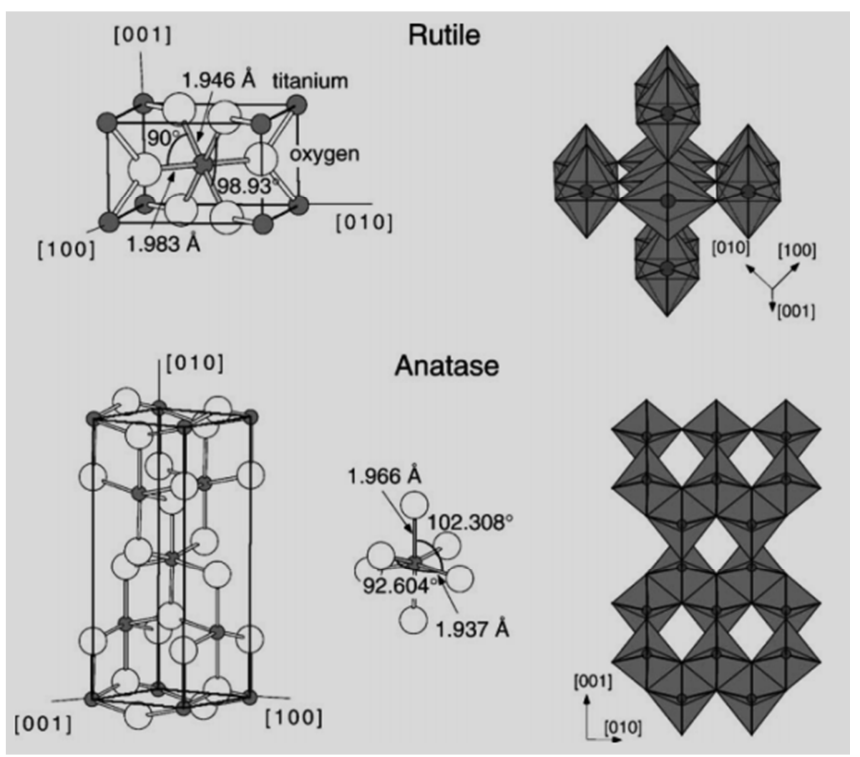

Figura 6 - Estruturas cristalinas do $\mathrm{TiO}_{2}$ : rutila e anatase [19].

Os pigmentos são partículas finas insolúveis introduzidas na tinta para obter características como cor, opacidade e proteção anticorrosiva. Os pigmentos anticorrosivos conferem esta propriedade à tinta por mecanismos químicos ou eletroquímicos, como ocorre, por exemplo, com o zarcão $\left(\mathrm{Pb}_{3} \mathrm{O}_{4}\right)$ e sais de zinco ou zinco em pó. Dentre os pigmentos, o dióxido de titânio $\left(\mathrm{TiO}_{2}\right)$ é um pó de cor branca muito utilizado pela indústria. Possui elevado poder de cobertura ou opacidade (quando comparado com outras tintas brancas ou de cor clara), além de excelente resistência química e à radiação solar. Possui duas formas cristalinas, anatásio e rutilo (Fig. 6), sendo que esta última é a mais utilizada por possuir maior índice de refração, maior poder de cobertura (30-40\% superior) e melhor resistência à radiação.

Os mecanismos básicos de proteção anticorrosiva sobre um substrato de aço são barreira, inibição (passivação anódica) e eletroquímico (proteção catódica). No mecanismo por barreira, a película aplicada sobre o substrato isola este do meio corrosivo, conferindo uma alta resistência nesta interface, diminuindo os processos de corrosão a níveis desprezíveis. A eficiência da proteção depende da espessura da barreira; entretanto, os revestimentos não são totalmente impermeáveis, de forma que transcorrido algum tempo o eletrólito alcança o metal e inicia o processo de corrosão. No processo de inibição, ou passivação anódica, pigmentos inibidores (como zarcão, cromatos e fosfatos de zinco) formam uma camada passiva sobre a superfície do metal, impedindo sua oxidação (corrosão). No mecanismo eletroquímico, ou proteção catódica, um metal de revestimento com comportamento anódico com relação ao metal protegido é depositado, formando uma pilha 
que se completa com a presença do eletrólito. Desta forma, o metal, que fica com comportamento catódico, é protegido.

Outro tipo de revestimento muito usado em metais para ambientes corrosivos são os polímeros. Estes materiais apresentam vantagens como peso reduzido, fácil transporte e instalação, flexibilidade e são atóxicos. Alguns polímeros que são utilizados são o neoprene (policloropreno), ebonite (borracha rígida de estireno-butadieno), teflon e polipropileno, dentre muitos outros $[5,8,20]$.

No caso dos aços inoxidáveis ou carbono, já empregados como partes de estruturas metálicas, uma estratégia interessante e eficiente é o uso de revestimentos protetores, uma vez que modificações do meio corrosivo são inviáveis (estruturas que ficam expostas ao ambiente natural, seja atmosférico ou em rio e mares), modificação do metal ou do processo também não são propostas eficientes se uma determinada liga metálica já oferece boas propriedades mecânicas ou se a estrutura já se encontra pronta.

\subsubsection{Inibidores de corrosão}

Inibidores são substâncias (ou mistura de substâncias) que, quando adicionadas ao meio em concentrações adequadas, reduzem ou eliminam a corrosão. Dentre as divisões mais importantes destas substâncias, elas são divididas em: anódicos, catódicos e de adsorção.

Os inibidores anódicos atuam retardando ou inibindo as reações que ocorrem no ânodo. Em geral, são substâncias que reagem com o produto de corrosão inicialmente formado, resultando em um filme aderente e insolúvel sobre a superfície do metal, impedindo a evolução de sua corrosão (polarização anódica). Nesta classe se inserem os hidróxidos, carbonatos, silicatos, boratos e fosfatos terciários de metais alcalinos. Por exemplo, no caso do uso do carbonato, a hidrólise deste ânion gera íons hidroxila, que formam um filme insolúvel com o metal oxidado na corrosão (Eqs. 18 e 19). Alguns autores denominam inibidores que deslocam o potencial para valores mais positivos de passivadores.

$$
\begin{aligned}
& \mathrm{CO}_{3}{ }^{2-}{ }_{(\mathrm{aq})}+2 \mathrm{H}_{2} \mathrm{O}_{(\mathrm{l})} \rightarrow 2 \mathrm{OH}^{-}{ }_{(\mathrm{aq})}+\mathrm{H}_{2} \mathrm{CO}_{3(\mathrm{aq})} \\
& \mathrm{M}^{\mathrm{n}+}{ }_{(\mathrm{aq})}+\mathrm{nOH}^{-}{ }_{(\mathrm{aq})} \rightarrow \mathrm{M}(\mathrm{OH})_{\mathrm{n}(\mathrm{s})}
\end{aligned}
$$

Os inibidores catódicos inibem as reações catódicas, impedindo a difusão do oxigênio e, consequentemente, a transferência de elétrons da semi-reação catódica, interrompendo assim o progresso da corrosão. Nesta classe de inibidores são utilizados sais solúveis de determinados metais, como sulfatos de zinco, magnésio e níquel. 
Os íons metálicos reagem com íons hidroxila formados pela reação catódica, formando uma camada de hidróxido insolúvel. No caso do zinco, a reação é apresentada pela equação 20.

$\mathrm{Zn}^{2+}{ }_{(\mathrm{aq})}+2 \mathrm{OH}_{(\mathrm{aq})}^{-} \rightarrow \mathrm{Zn}(\mathrm{OH})_{2(\mathrm{~s})}$

Esta reação também ocorre espontaneamente em águas com dureza temporária (bicarbonato de cálcio, eq. 21 e 22).

$\mathrm{HCO}_{3}{ }^{-}(\mathrm{aq})+\mathrm{OH}_{(\mathrm{aq})}^{-} \rightarrow \mathrm{CO}_{3}{ }^{2-}(\mathrm{aq})+\mathrm{H}_{2} \mathrm{O}_{(\mathrm{l})}$

$\mathrm{Ca}^{2+}{ }_{(\mathrm{aq})}+2 \mathrm{OH}_{(\mathrm{aq})}^{-} \rightarrow \mathrm{Ca}(\mathrm{OH})_{2}(\mathrm{~s})$

Por fim, os inibidores de adsorção atuam formando películas protetoras sobre áreas anódicas e catódicas, interferindo no processo de corrosão. Apresentam esta características alguns colóides, sabões de metais pesados e substâncias orgânicas com átomos de oxigênio, nitrogênio ou enxofre (aldeídos, aminas, e uréia e tiouréia substituídas) [3].

\subsection{Polímeros condutores}

O uso de polímeros pelo homem, pelo que se tem registro, data desde a antiguidade, da época em que egípcios e romanos utilizavam estes materiais como cola e para vedação de vasilhames. Desde a sua descoberta, os polímeros foram conhecidos por um longo período como materiais exclusivamente isolantes. Entretanto, a partir da década de 1950 uma nova ideia começou a ser explorada: a de um material polimérico apresentar condutividade elétrica. Para atingir este objetivo, cargas inorgânicas condutoras (como negro de fumo e fibras metálicas) foram inseridas em uma matriz polimérica. Esta estratégia se baseava em uma mistura física entre dois materiais diferentes, a matriz polimérica (completamente isolante) e um material condutor. Esta nova classe de materiais foi chamada de polímeros condutores extrínsecos, pois a condutividade era obtida pela inserção de uma carga diferente do polímero. Um dos problemas que foram encontrados é que a carga condutora inserida geralmente possuía maior rigidez que o polímero, comprometendo a flexibilidade do material resultante.

Em 1976, três grupos de pesquisa independentes liderados por Shirakawa, MacDiarmid e Heeger descobriram que alguns polímeros, em determinadas condições, eram capazes de apresentar condutividade elétrica. Este grupo de materiais, cuja condutividade dependia somente da própria cadeia polimérica, sem a necessidade de inserção de outras cargas, foi chamado de polímeros condutores intrínsecos, ou "metais sintéticos" [21]. A partir desta descoberta, um novo campo de pesquisa começou a ser explorado devido às diversas possibilidades de aplicação destes materiais. Propriedades como condutividade e 
eletrocromismo conferiram possibilidades de avanços nos campos de eletrodos de baterias, LEDs, células solares e blindagem eletromagnética e proteção contra a corrosão. Devido às potencialidades de aplicações destes materiais e pioneirismo neste campo, em 2000 estes pesquisadores foram premiados com um Prêmio Nobel devido à relevância de sua descoberta [22-24]. Atualmente, os polímeros condutores encontram diversas aplicações, como em janelas eletrocrômicas, eletrodos para baterias recarregáveis com baixo peso, neurotransmissor e proteção contra a corrosão [25-31].

A condutividade por meio de uma cadeia orgânica torna-se possível por meio de duplas ligações conjugadas. Uma maneira simples de entender como ocorre a condutividade é pensar em um processo de oxidação desta cadeia, em que elétrons dos orbitais $\pi$ sejam parcialmente removidos; estas "lacunas" geradas pelos elétrons removidos possibilitam a mobilidade eletrônica ao longo da cadeia, e, consequentemente, a condutividade. Outra possibilidade é se ocorrer uma redução na cadeia polimérica; neste caso, os orbitais $\pi^{*}$ serão parcialmente preenchidos, promovendo a condutividade.

A necessidade de um polímero condutor apresentar estrutura conjugada (duplas ligações alternadas) se justifica porque, enquanto as ligações $\sigma$ são responsáveis pela estabilidade da estrutura polimérica, os orbitais $\pi$ e $\pi^{*}$ se comportarão como uma região no espaço por onde os elétrons se movimentarão. Desta maneira, por meio do controle do estado de oxidação da cadeia pode-se obter, para um mesmo material polimérico, desde um estado completamente isolante até um condutor. O primeiro polímero condutor descoberto foi o poliacetileno; ao ser dopado com iodo, este polímero apresentou mudança de coloração, passando de um filme prateado para dourado. Esta alteração foi acompanhada também de uma mudança na condutividade, que passou de um valor menor que $10^{-5}(\Omega . \mathrm{cm})^{-1}$, na forma isolante, para um valor na ordem de $10^{3}(\Omega . \mathrm{cm})^{-1}$, na sua forma condutora. Esta alteração foi possível por meio da exposição deste material a agentes oxidantes ou redutores [32]. Posteriormente, com o desenvolvimento deste campo, propriedades condutoras foram descobertas também em outros polímeros (Fig. 7).

O processo de alteração de propriedades físico-químicas (como cor, solubilidade e condutividade) de polímeros intrinsicamente condutores por agentes oxidantes ou redutores é denominado dopagem. O termo é utilizado em analogia aos semicondutores inorgânicos, em que o mecanismo de aumento da condutividade é explicado com auxílio da teoria de bandas. A dopagem representa uma mudança do estado de oxidação da cadeia, por meio da remoção ou adição de elétrons nos pontos de instauração existentes. Os orbitais moleculares $\pi$ e $\pi^{*}$, apresentam, respectivamente, baixa energia de ionização e alta afinidade eletrônica, quando 

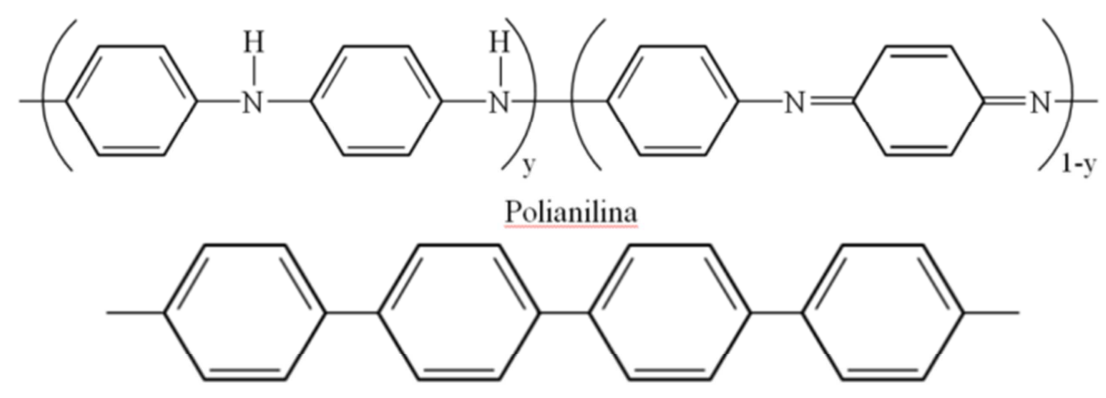

Polifenileno

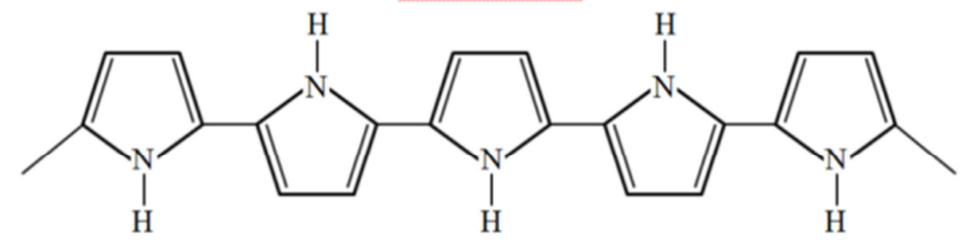

Polipirrol

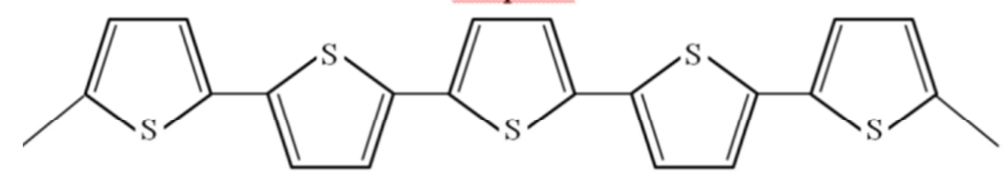

Politiofeno<smiles>C/C=C\C=C/C=C\C</smiles>

Poliacetileno

Figura 7 - Polímeros intrinsicamente condutores [21].

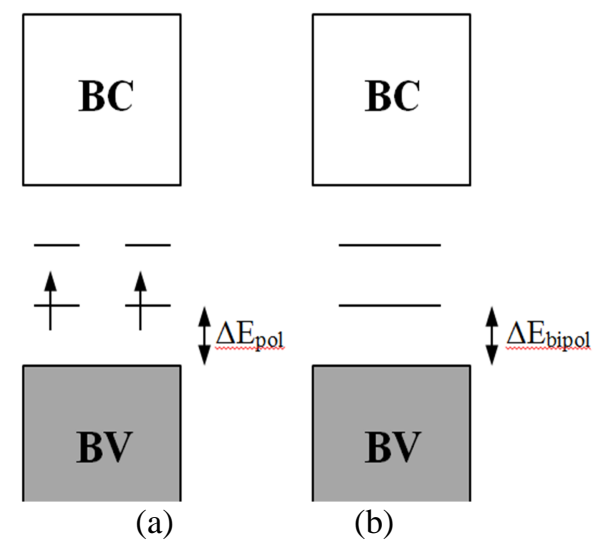

Figura 8 - Modelo de bandas para um polímero condutor contendo (a) dois polarons e (b) um bipolaron [32].

comparados aos orbitais $\sigma$ e $\sigma^{*}$. Assim, a exposição do polímero a um agente oxidante promove a retirada de um elétron do orbital $\pi$, o qual, pela teoria de bandas, passa a ser o nível eletrônico de mais alta energia ocupado (HOMO), sendo chamado de banda de valência.

Por se tratar de uma oxidação da cadeia, esta dopagem é denominada dopagem tipo $\mathrm{p}$ (em analogia aos semicondutores inorgânicos). Se um agente redutor for utilizado, um elétron 
será adicionado no orbital $\pi^{*}$, e este passa a ser o nível eletrônico de mais baixa energia desocupado (LUMO), sendo chamado de banda de condução. Este tipo de dopagem, por se tratar de uma redução da cadeia, é chamada de dopagem tipo n. A cadeia polimérica passa então a ser um ânion ou cátion polimérico, possuindo um contra-íon nos sítios oxidados ou reduzidos, para contrabalancear o desequilíbrio de carga. Os elétrons desemparelhados, seja na banda de valência ou na banda de condução, serão os responsáveis pela condutividade eletrônica ao longo da cadeia. A diferença de energia entre as bandas de valência e condução é denominada band gap, e determina as propriedades elétricas intrínsecas do material [32].

A escolha do dopante dependerá da natureza do polímero; por exemplo, poliacetileno e poli-p-fenileno admitem dopagem tipo $\mathrm{p}$ ou $\mathrm{n}$, enquanto polipirrol e politiofeno admitem somente dopagem tipo p. O modelo que justifica a condutividade em polímeros condutores com base na teoria de bandas, fundamentada nos semicondutores orgânicos, foi modificado após a constatação de que a condutividade em polímeros condutores intrínsecos como poli-pfenileno, polipirrol e poliacetileno não estava associada a elétrons desemparelhados. A remoção de um elétron da banda de valência, resultando em um elétron desemparelhado, resulta em uma estrutura denominada polaron; a retirada do segundo elétron resulta em uma estrutura denominada bipolaron (Fig. 8).

A princípio, é intuitivo pensar que a formação de uma estrutura tipo polaron é favorecida em relação à estrutura bipolaron, devido à repulsão eletrônica. Entretanto, a oxidação da cadeia polimérica está associada a distorções no retículo cristalino, causando o surgimento de novos níveis eletrônicos de energia (estados eletrônicos localizados) entre as bandas de valência e condução (surgindo os chamados estados polaron e bipolaron). Este modelo é semelhante ao que ocorre quando inserimos um elemento semicondutor para aumentar a condutividade de um material. Neste caso, pela teoria de bandas, o elemento semicondutor promove o surgimento de níveis eletrônicos de diferentes energias que a banda de valência e a banda de condução. O resultado é uma diminuição no band gap, o que faz com que os elétrons necessitem de menor quantidade de energia para se deslocarem de seu nível energético inicial. Uma vez que o deslocamento de níveis de energia dos elétrons é facilitado, haverá maior probabilidade de se encontrar elétrons desemparelhados e, por consequência, um aumento na condutividade da estrutura será observado.

No caso dos polímeros, quando o primeiro elétron é retirado, a distorção no retículo cristalino resulta na formação de níveis eletrônicos intermediários às bandas de valência e condução. A remoção de segundo elétron promove uma distorção no retículo, tal que a 
energia entre os novos níveis eletrônicos formados é menor. Desta forma, a formação de um bipolaron é termodinamicamente mais favorecida que a formação de um polaron [32].

A natureza do dopante e o grau de dopagem influenciam na formação dos estados eletrônicos intermediários. Por exemplo, o polipirrol, sob baixo nível de dopagem, apresenta a formação de um estado polaron; em níveis moderados de dopagem, já se observa a formação de um estado bipolaron, com o respectivo deslocamento de energia dos níveis eletrônicos. Finalmente, em altos níveis de dopagem, observa-se a formação de bandas bipolarônicas. A condutividade está diretamente ligada a cada um destes estados, que variam, respectivamente, da menor para a maior condutividade para os estados em questão. A diminuição do band gap entre os níveis intermediários de energia que surgem entre as bandas de valência e condução foi confirmada por meio de um espectro de absorção óptica dos filmes de polipirrol com diferentes graus de dopagem; esta menor energia entre os níveis eletrônicos resultou em um aumento da condutividade final do filme [32].

A partir dos estudos pioneiros de Shirakawa, Heeger e MacDiarmid desta nova classe de materiais, diversos grupos ao redor do mundo passaram a dedicar suas pesquisas para esta área, resultando na melhora das propriedades físico-químicas e tornando estes materiais viáveis do ponto de vista de aplicação tecnológica.

Embora sejam vários os polímeros condutores que têm sido aplicados em diversos setores, este estudo se restringiu ao uso e estudo da polianilina. Por isso, os estudos e aplicações que têm sido publicados sobre este polímero estão descritas a seguir

\subsection{Estado da arte}

Embora tenha representado um grande avanço para sua época, os polímeros condutores não encontravam aplicações tecnológicas devido a sua baixa estabilidade. A descoberta da polianilina (PAni) foi um grande avanço, pois este polímero apresentava grande estabilidade química e poderia ser facilmente sintetizado química e eletroquimicamente (neste último caso, a potencial constante - potenciostática, corrente constante - galvanostática ou amperostática, ou ainda por voltametria cíclica). As polianilinas assim sintetizadas apresentavam característica fibrilar, e o domínio de sua síntese foi de grande importância na substituição do poliacetileno.

Em 1980, Diaz et al. [33] descreveram a síntese eletroquímica do polímero por voltametria cíclica. Como vantagem à síntese potenciostática, os autores notaram que na síntese potenciodinâmica foi observado maior aderência entre a PAni e o eletrodo da platina, em detrimento da baixa aderência que costumava ser observada na síntese potenciostática. Os 
primeiros estudos de PAni eletrodepositada sobre aço inox para proteção contra a corrosão foram feitos em 1984 por DeBerry et al. [34]. Os estudos apontaram que a PAni depositada sobre um aço pré-passivado reduzia a velocidade de corrosão do metal, levando os pesquisadores a concluir que o estado passivado do metal era mantido pela camada de PAni.

Em 1984, Kitani et al. [35] estudaram polianilinas eletro sintetizadas por voltametria cíclica e potenciostaticamente, sobre eletrodo de platina. Por meio de caracterização eletroquímica por voltametria cíclica em solução isenta de monômero, os autores explicaram a reversibilidade da oxidação e redução do polímero em função da dopagem e desdopagem da cadeia com um íon $\mathrm{H}^{+}$. Dois tipos de estruturas protonadas são apresentados pelos autores, sendo uma com um íon $\mathrm{H}^{+}$sobre o átomo de nitrogênio, e contrabalanceado por um contraíon $\mathrm{X}^{-}$, vindo do ácido usado como eletrólito. Os autores ainda identificaram maior crescimento do polímero em meio de $\mathrm{H}_{2} \mathrm{SO}_{4}$ que em $\mathrm{HClO}_{4}$, e atribuíram este efeito devido à carga -2 do ânion $\mathrm{SO}_{4}{ }^{2-}$ em relação à carga -1 do ânion $\mathrm{ClO}_{4}{ }^{-}$.

Neste mesmo ano, Ohsaka et al. [36] estudaram a influência do meio reacional na estrutura da PAni, por meio de espectroscopia vibracional com transformada de Fourrier na região do infravermelho (IV) e resposta eletroquímica. Foram estudados meios de síntese ácido $\left(\mathrm{Na}_{2} \mathrm{SO}_{4} / \mathrm{H}_{2} \mathrm{SO}_{4}\right)$, básico $\left(\mathrm{NaClO}_{4}\right.$ e piridina em meio de acetonitrila) e neutro $\left(\mathrm{HPO}_{4}{ }^{2-}\right.$ $/ \mathrm{H}_{2} \mathrm{PO}_{4}{ }^{-}$) A maior espessura do filme encontrada foi de $300 \mathrm{~nm}$, para o sistema em meio ácido, e a menor foi de $15 \mathrm{~nm}$ para o meio básico. As sínteses foram realizadas potenciostaticamente, a 1,0 V ca (vs. eletrodo de calomelanos saturado em cloreto) por 10 minutos, sobre três superfícies diferentes: platina (para comparar os perfis voltamétricos), eletrodos transparentes de $\operatorname{In}_{2} \mathrm{O}_{3}$ (para análise por espectroscopia vibracional na região do IV) e grafite pirolítico. Os autores observaram diferenças nos perfis voltamétricos para os polímeros sintetizados nos diferentes meios de síntese. Ainda, o substrato mostrou-se ter grande influência no produto formado, de modo que diferentes superfícies, em iguais condições de síntese, não resultaram no mesmo produto. Pelos resultados da espectroscopia de IV os autores concluíram que a síntese da cadeia polimérica ocorreu pela formação de ligações $\mathrm{C}-\mathrm{N}=\mathrm{C}$ e C-NH-C. Os efeitos estéricos e químicos dos íons em solução e da natureza do solvente determinaram diferentes posições dos substituintes no grupo fenil no decorrer da polimerização; enquanto que a PAni sintetizada em meio de ácido sofreu substituição na posição para (com relação ao grupo amínico), os outros dois meios de síntese induziram substituições na posição meta.

As espessuras de filmes obtidos mostraram que, devido ao padrão de substituição do anel aromático, o meio ácido favorece maior grau de polimerização (substituição para). O 
meio básico resultou em menor espessura do filme. As respostas eletroquímicas de cada polímero foram obtidas nas mesmas soluções de síntese, isentas de monômero. Para o polímero em meio ácido, a resposta eletroquímica resultou em vários picos de oxidação e redução, comportando-se como um composto de múltiplas valências. Já os polímeros em meios básico e neutro apresentaram somente picos de oxidação, não caracterizando comportamento reversível. Quando a PAni sintetizada em meio ácido foi colocada em meios com maiores valores de $\mathrm{pH}$, observou-se diminuição das correntes de pico, o que caracteriza que o comportamento eletroativo do polímero está associado ao íon $\mathrm{H}^{+}$, e uma diminuição da concentração desta espécie causa uma consequente diminuição da corrente de pico. Esta observação levou também os autores a concluir que a variação dos estados de oxidação do polímero está associada à adição ou eliminação do $\mathrm{H}^{+}$. Mesmo em solução ácida, os polímeros sintetizados em meios neutro e básico mostraram-se inativos eletroquimicamente. Isto mostrou que a orientação do crescimento da cadeia pela substituição no anel aromático nas posições para (no polímero sintetizado em meio ácido) e meta (nos polímeros sintetizados em meio neutro e básico) determina se o mesmo terá ou não comportamento eletroativo. Esta observação pode ser justificada pelo fato de que o polímero que cresce com substituição na posição para do grupo fenil possui maior conjugação por sua orientação linear, o que não ocorre nos polímeros que crescem por substituição no grupo meta.

O comportamento eletroquímico observado nos polímeros sintetizados sobre platina e $\mathrm{In}_{2} \mathrm{O}_{3}$ foi muito semelhante, e diferente no polímero sintetizado sobre grafite pirolítica. Neste último substrato, os polímeros apresentaram comportamento eletroativo, independente de seu meio de síntese (embora esta resposta foi observada com menor intensidade para os polímeros sintetizados em meios neutro e básico). Isto levou os autores a concluir que, além do meio de síntese, o substrato exerce influência na formação dos produtos, devido a diferentes atividades catalíticas de cada material sobre o polímero sintetizado. Além destes resultados, medidas de condutividade mostraram que a PAni em meio ácido possui comportamento condutor, enquanto que em meios básico e neutro possui comportamento isolante. Em outro trabalho os autores apresentam um estudo envolvendo as propriedades eletrocrômicas da PAni sintetizada sobre platina [37]. Neste caso, a cor apresentada pelo polímero foi função do potencial aplicado.

Genies et al. [38] mostraram a influência do potencial na estrutura da PAni eletropolimerizada sobre platina em diferentes meios: $\mathrm{NH}_{4} \mathrm{~F} / \mathrm{HF}, \mathrm{H}_{2} \mathrm{SO}_{4}$ e $\mathrm{H}_{2} \mathrm{SO}_{4} / \mathrm{Na}_{2} \mathrm{SO}_{4}$. A síntese foi realizada por voltametria cíclica, iniciando-se no potencial de $-0,2 \mathrm{~V}\left(v s . \mathrm{Cu} / \mathrm{CuF}_{2}\right)$. Em meio de $\mathrm{NH}_{4} \mathrm{~F} / \mathrm{HF}$, o potencial final menor que $0,7 \mathrm{~V}$ resultou em um voltamograma com 
2 pares de picos (cada par envolvendo um pico de oxidação e outro correspondente de redução, ambos a potenciais muito próximos). $\mathrm{O}$ primeiro par foi observado próximo de $0 \mathrm{~V}$, e o segundo é observado a potenciais próximos (e menores) que 0,7V. Quando maiores valores de potencial final foram empregados, um novo par de picos passou a ser observado (em torno de 0,4 V). Os autores atribuíram este novo par de picos a um processo de oxiredução independente do polímero, resultando em uma estrutura polimérica diferente, que pode ser um acoplamento orto entre os monômeros de anilina.

Devido às maiores correntes de oxidação e redução, os autores concluíram que o processo de nucleação e crescimento da PAni sintetizada em meio de $\mathrm{HF} / \mathrm{NH}_{4} \mathrm{~F}$ é favorecido em relação ao meio de $\mathrm{H}_{2} \mathrm{SO}_{4}$ e $\mathrm{H}_{2} \mathrm{SO}_{4} / \mathrm{Na}_{2} \mathrm{SO}_{4}$, além deste sistema apresentar uma aderência superior com relação aos outros meios em eletrodo de platina e carbono. PAni sintetizada em meio de $\mathrm{HF} / \mathrm{NH}_{4} \mathrm{~F}$ apresentou uma estrutura mais compacta com fibras rígidas; por outro lado, em meio de $\mathrm{H}_{2} \mathrm{SO}_{4}$ (com ou sem $\mathrm{Na}_{2} \mathrm{SO}_{4}$ ), as fibras da PAni não eram rígidas e não apresentaram grande aderência. As sínteses foram realizadas também potenciostaticamente, a diferentes valores de potenciais. Em meio de $\mathrm{HF} / \mathrm{NH}_{4} \mathrm{~F}$, não se observou crescimento da PAni em potencial de $0,6 \mathrm{~V}$ (vs. $\mathrm{Cu} / \mathrm{CuF}_{2}$ ). A partir do potencial de $0,7 \mathrm{~V}$, observou-se crescimento do polímero, os quais foram posteriormente caracterizados por meio de suas respostas eletroquímicas nos eletrólitos em que foram sintetizados, na ausência de monômero (anilina). $\mathrm{Na}$ síntese utilizando potencial de $0,7 \mathrm{~V}$, a resposta eletroquímica mostrou somente dois pares de picos redox; este padrão de voltamograma foi atribuído pelos autores a um crescimento da cadeia com padrão de substituição para. Utilizando potenciais de síntese maiores que $0,7 \mathrm{~V}$, o terceiro par redox passa a ser observado, o qual foi atribuído pelos autores como um acoplamento orto da anilina.

A deposição potenciostática da PAni em meio de $\mathrm{H}_{2} \mathrm{SO}_{4}$ (com e sem $\mathrm{Na}_{2} \mathrm{SO}_{4}$ ) resultou em um perfil diferente do gráfico i-t, e em um filme com baixa aderência, o que levou os autores a concluir que um mecanismo diferente de polimerização ocorre entre os dois meios. Os autores concluíram deste trabalho que vários parâmetro influenciam o padrão de substituição da anilina, em orto ou para. A presença de dois ou três pares de picos redox foi atribuído pelos autores como o meio de saber qual tipo de mecanismo de polimerização está ocorrendo, ou se os dois ocorrem simultaneamente. O meio reacional pode ou não possibilitar diferentes padrões de substituição da anilina, porém o controle do potencial é fundamental para esta determinação. Aplicações com a PAni foram exploradas neste mesmo ano por Paul et al. [39]. Eles utilizaram a síntese de PAni sobre eletrodo de ouro, por voltametria cíclica para aplicá-la em sensores e dispositivos eletrônicos. 
MacDiarmid et al. [40] constatou o caráter reversível na oxidação/redução da PAni protonação/desprotonação do polímero; tal resultado também pode ser observado por via eletroquímica, em um voltamograma cíclico do polímero sobre um metal inerte, como platina. Esta fácil interconversão do polímero permite grandes possibilidades de aplicações, uma vez que com elas propriedades físicas como cor e condutividade são drasticamente modificadas.

De modo geral, as respostas eletroquímicas da PAni sintetizada química ou eletroquimicamente são idênticas (embora, como já mostrado nos trabalhos citados, os parâmetros eletroquímicos e o meio reacional influenciam a morfologia do polímero). Além do mais, diferentes íons não deslocam o potencial do primeiro processo redox da PAni (E=0,13V vs. ECS, em $\mathrm{HCl}$ 1,0 $\left.\mathrm{mol} \mathrm{L}^{-1}\right)$, mas o $\mathrm{pH}$ pode afetá-lo. Segundo MacDiarmid et al. [22], o primeiro pico redox pode sofrer influência na faixa de $\mathrm{pHs}$ entre -1 e 2; ele se desloca $59 \mathrm{mV}$ por unidade de $\mathrm{pH}$ para maiores potenciais à medida que se diminui o pH. Já no intervalo de $\mathrm{pH}$ entre 1 e 4 esta influência não é observada. Para o segundo pico de oxidação, este estudo realizado por MacDiarmid et al. revelou que no intervalo de pHs entre 0 e 4, uma correlação linear entre $\mathrm{pH}$ e potencial é encontrada, e o pH sofre um decréscimo de $120 \mathrm{mV}$ por unidade de $\mathrm{pH}$ (aumentando-se este parâmetro).

PAni na forma de base esmeraldina (isolante) é convertida para seu estado condutor por meio da imersão do polímero em um ácido. Os autores explicam que a dopagem da cadeia se dá por meio da protonação dos nitrogênios da cadeia (preferencialmente nos grupos amina, por serem estes bases mais fortes que os grupos imina). Esta protonação da cadeia despopula parcialmente os elétrons presentes nas ligações $\pi$, o que resulta em conjugação da cadeia polimérica, com 4 híbridos de ressonância. A variação de coloração do filme também pode ser visualizada pela voltametria cíclica: de $-0,2$ a $0 \mathrm{~V}$ - amarelo; de 0 a 0,2V - verde claro; de 0,2 a $0,5 \mathrm{~V}$ - verde; de 0,5 a 0,7 - azul; de 0,7 a 1,0V - violeta. As estruturas da PAni, com suas diferentes características, estão apresentadas na figura 9 e tabela 1.

Quando amostras de PAni foram submetidas a ensaios de voltametria cíclica em meios com pHs superiores a 4, os processos de oxidação e redução não foram observados prontamente; a $\mathrm{pH}=6$, a PAni mostrou-se completamente inativa [22]. Chiang et al. [41] estudaram a dopagem da PAni, pela imersão do polímero em sua forma isolante (base esmeraldina) em solução de $\mathrm{HCl}$. Os autores concluíram que uma nova forma de dopagem ocorria por meio da adição de um próton no átomo de $\mathrm{N}$ da cadeia (formando assim um sal), e não pela oxidação parcial das ligações $\pi$, como ocorre em outros polímeros condutores. Desta forma, se conclui que a condutividade do material depende de duas variáveis, o grau de 
oxidação e de protonação da cadeia; não há alteração no número de elétrons que existem ao longo da cadeia [23,42].

Focke et al. [43] também relacionaram a condutividade da PAni com um estado de oxidação intermediário (sal esmeraldina, com metade das unidades poliméricas oxidadas e metade reduzidas). Os autores observaram a formação de um radical cátion a baixos valores de $\mathrm{pH}$, o qual mostrou-se estável somente em um intervalo limitado de potencial quando o polímero é submetido a uma voltametria cíclica em eletrodo inerte, como platina. A altos valores de $\mathrm{pH}$ a protonação da cadeia é incompleta; mesmo assim, a protonação parcial da cadeia foi suficiente para diminuir a resistividade do polímero em 3 ordens de grandeza, quando este foi imergido em um eletrólito. Os autores concluíram com os resultados observados que a reação de transferência de próton, que ocorre mais efetivamente a pHs ácidos, determina o mecanismo de condução na PAni. Estas conclusões corroboram com daquelas obtidas por trabalhos de outros grupos.

Assim, de acordo com os trabalhos citados e as conclusões tecidas pelos autores, a dopagem pode ser feita por via química ou eletroquímica. Na dopagem química, os dopantes utilizados podem ser agentes oxidantes, resultando em orbitais $\pi$ (banda de valência) semipreenchidos, constituindo a dopagem tipo p. Se o agente dopado utilizado for um agente redutor, se obtém orbitais $\pi^{*}$ (banda de condução) semipreenchidos, constituindo a dopagem tipo n. A diferença de energia entre os orbitais $\pi^{*}-\pi$ é denominada band gap. A partir de 1980, MacDiarmid e Heeger descobriram que a dopagem podia ser feita também por via eletroquímica, por meio do controle do potencial aplicado [45].

Os polímeros condutores podem ser sintetizados por vários métodos, sendo que os mais utilizados são a síntese química e eletroquímica. Na síntese química o polímero é obtido a partir da oxidação inicial de monômeros, a qual ocorre por meio da adição de um agente oxidante no meio reacional. São formadas as primeiras espécies de cátions radicais, as quais reagem com outra molécula de monômero, gerando dicátions, possibilitando que a cadeia cresça bidirecionalmente. As cadeias inicialmente formadas, ainda com baixa massa molecular, são denominadas oligômeros. A partir daí ocorre a etapa de propagação, onde ocorre o crescimento da cadeia pela reação dos oligômeros com moléculas de monômeros, de forma auto catalítica. O fim do processo é marcado pela etapa de terminação, em que as cadeias se unem, aumentando a massa molecular média do polímero e eliminação os sítios de reação (propagadores de cadeia) [46]. 


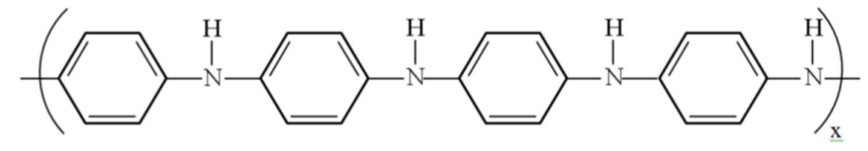

Leucoesmeraldina

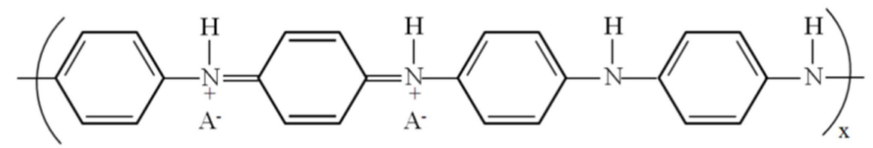

Sal esmeraldina

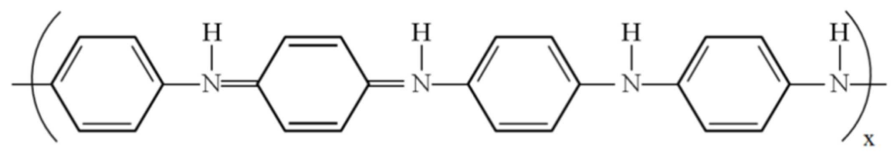

Base esmeraldina

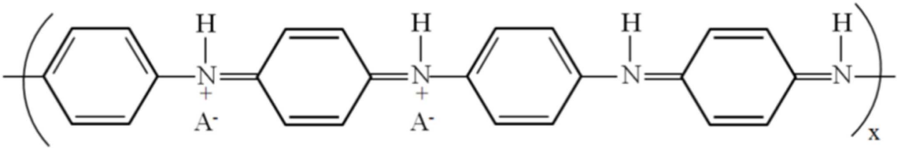

Pernigranilina

Figura 9 - Estruturas da polianilina [44].

Tabela 1 - Propriedades físico-químicas das diferentes estruturas da polianilina [44]

\begin{tabular}{|cccccc|}
\hline Nome da estrutura & Condutividade & Estado de oxidação & Cor & $\boldsymbol{\lambda}$ de máx. absorção/nm \\
\hline Leucoesmeraldina & Isolante & Reduzido & Amarela & 310 \\
\hline Sal esmeraldina & Condutor & Parcialmente reduzido & Verde & 320,420 e 800 \\
Base esmeraldina & Isolante & Parcialmente reduzido & Azul & 320 e 620 \\
\hline Pernigranilina & Isolante & Oxidado & Púrpura & 320 e 530 \\
\hline
\end{tabular}

Parâmetros como temperatura, tempo de síntese e meio reacionais são fundamentais nas características finais do polímero obtido. O produto final é obtido na forma de um pó; para obter o polímero na forma de um filme, este pó deve ser dissolvido em um solvente adequado e em seguida seco em condições próprias para aquele sistema. A síntese eletroquímica é feita por métodos estáticos ou dinâmicos, por meio do controle do potencial ou corrente. No método dinâmico é utilizada a técnica de voltametria cíclica, em que o potencial é variado dentro de um intervalo determinado, e varrido a uma velocidade específica. Parâmetros como intervalo de potencial, velocidade de varredura e meio reacional determinam as características do polímero, e o número de ciclos determina a espessura do filme. Nos métodos estáticos, o polímero é obtido pelo controle do potencial (potenciostática) ou da corrente (galvanostática). As características do polímero, neste caso, são determinadas pelo potencial ou corrente selecionados, tempo de aplicação e meio reacional. 
A síntese eletroquímica dispensa o uso de agentes oxidantes, uma vez que a oxidação dos monômeros é feita pelo controle dos parâmetros eletroquímicos. O polímero é obtido na forma de um filme sobre o próprio eletrodo, que deve estar no meio reacional, sendo este o eletrodo de trabalho. Ainda, utiliza-se um eletrodo de referência (para monitoramento do potencial do eletrodo de trabalho) e contra eletrodo (ou eletrodo auxiliar). Desta forma, na síntese eletroquímica a síntese do polímero sobre um substrato dispensa também o uso de solventes. No caso de metais, a eletrodeposição do polímero em solventes comuns (como soluções aquosas de $\mathrm{HCl}$ e $\mathrm{H}_{2} \mathrm{SO}_{4}$, por exemplo) pode ocasionar a oxidação da superfície; para contornar este problema, uma alternativa é utilizar solventes orgânicos na polimerização. A solubilidade do monômero é aumentada e como consequência a formação do filme de polímero ocorre mais rapidamente, impedindo a oxidação da superfície metálica. Além disso, combinando-se adequadamente solvente e substrato metálico, pode-se obter um aumento de aderência do polímero ao substrato [47].

Vários trabalhos bem-sucedidos têm sido reportados utilizando a PAni como revestimento protetor contra a corrosão. Lu et al. [48] aplicaram PAni quimicamente sintetizada como primer sobre aço carbono, e foi recoberta com uma segunda camada de resina epóxi. A PAni foi depositada na forma desdopada, porém testes foram realizados com o polímero dopado, por meio da exposição deste (já depositado sobre o aço) a uma solução aquosa de ácido sulfônico. Sobre o filme foi feito um risco, a fim de observar a corrosão nesta pequena área exposta do metal, contendo o revestimento de PAni ao seu redor. Os testes de corrosão foram realizados em soluções aquosas ácida ( $\mathrm{HCl}$ diluído) e salina $(\mathrm{NaCl} 3,5 \%)$. Os autores observaram, por meio de ensaios de polarização potenciodinâmica, espectroscopia de impedância eletroquímica (EIE) e espectroscopia foto eletrônica excitada por raios-X (XPS), que a PAni apresentou uma boa proteção contra a corrosão do substrato. Nas áreas expostas do metal, os autores justificaram que a proteção ocorreu pela formação de um par galvânico entre o metal e o polímero, que resultou na formação de óxidos de ferro $\left(\gamma-\mathrm{Fe}_{2} \mathrm{O}_{3}\right.$ e $\left.\mathrm{Fe}_{3} \mathrm{O}_{4}\right)$, os quais foram os responsáveis pela proteção nesta região. $\mathrm{O}$ grau de proteção observado depende também do ambiente corrosivo; ou seja, no caso da PAni dopada, maior efetividade na proteção foi encontrada para ambiente contendo $\mathrm{HCl}$. Por fim, os autores observaram que a Pani apresentou uma baixa aderência com o substrato, e que melhores resultados podem ser obtidos se esta aderência for aumentada.

Ahmad et al. [49] estudaram PAni sintetizada quimicamente em meio de $\mathrm{HCl}$; o polímero foi desdopado em solução de amônia e novamente dopada em ácido dimetilsulfóxido (DMSO). Em seguida, o polímero foi aplicado sobre diferentes aços 


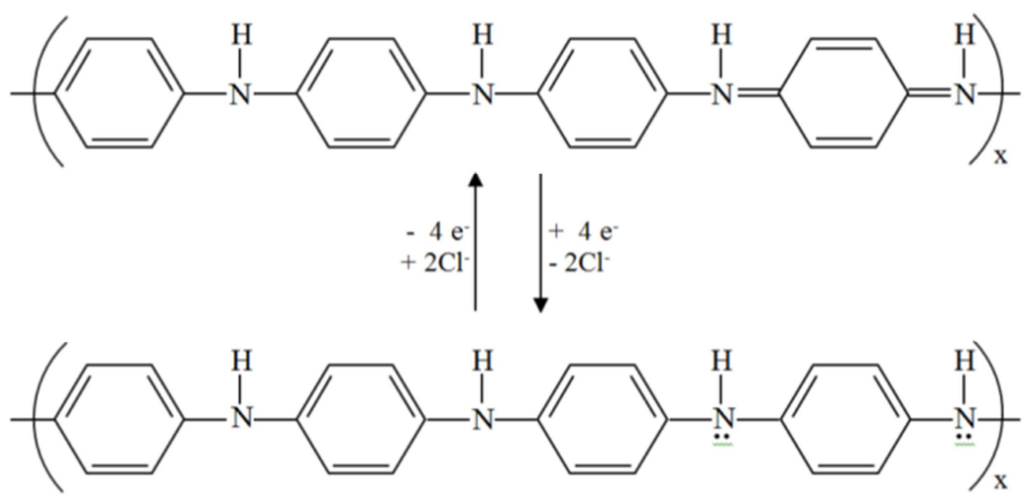

Figura 10 - Mecanismo de interconversão entre os estados esmeraldina e leucoesmeraldina da PAni [49].

inoxidáveis (304, 410 e 430) e em aço carbono 1018, por meio da evaporação do ácido. Em cada amostra foi feito um risco sobre o revestimento, e o comportamento das amostras frente à corrosão foi acompanhado pela medida de potencial de circuito aberto (PCA) em solução de $\mathrm{H}_{2} \mathrm{SO}_{4}$ diluído. No momento em que os defeitos foram provocados nos filmes, houve uma diminuição do PCA, seguido de um rápido aumento do mesmo. O bom desempenho apresentado pela PAni foi justificado pelos autores pela habilidade do polímero em passivar a superfície do aço inoxidável; como consequência, o polímero se reduz ao estado leucoesmeraldina, constituindo-se, portanto, como uma proteção anódica. O estado esmeraldina é obtido novamente pela oxidação da forma leucoesmeraldina pelo ar, de forma que o polímero pode atuar protegendo o metal indefinidamente (Fig. 10).

Entretanto, os autores observaram que o revestimento não foi tão efetivo na proteção dos aços inox em ambiente ácido contendo cloreto. Este comportamento foi atribuído a uma possível porosidade da PAni, o que permitiu a entrada do íon cloreto e o surgimento de pites. Outra justificativa atribuída pelos autores é a baixa aderência entre o filme e o substrato, o que causou desprendimento da película após algum tempo. Esta falta de aderência foi melhorada pelo pré-tratamento do metal com agentes quelantes, ácido fosfórico e sulfonato de alizarina; segundo os autores, estas substâncias reagem com o metal $(\mathrm{Fe})$ e formam estruturas que promovem a aderência do polímero.

Estudos de revestimentos de PAni para aços inoxidáveis têm sido relatados na literatura, utilizando diversas condições de síntese (diferentes pHs, tampões, temperaturas, concentrações dos reagentes, agentes oxidantes, etc.) e diferentes formas de aplicação sobre o aço, utilizando tanto estados dopado como desdopado do polímero. Moraes et al. [50] conseguiram boa aderência de um revestimento de PAni sobre aço 304 utilizando síntese eletroquímica em meio de tampão fosfato ( $\mathrm{pH}$ em torno de 2). Os testes de corrosão em $\mathrm{NaCl}$ $3,0 \%$ mostraram que o polímero promoveu um deslocamento positivo do potencial de 
corrosão, alcançando valores de $-0,130 \mathrm{~V}$ para a PAni dopada, e $-0,175 \mathrm{~V}$ para o polímero desdopado (eletrodo de referência: ECS). Ambos os filmes foram sintetizados por voltametria cíclica, sendo obtidos na forma de sal esmeraldina (devido ao ambiente ácido da síntese); a forma desdopada foi obtida por imersão do aço revestido em solução de $\mathrm{NH}_{4} \mathrm{OH}$. A corrente de corrosão foi diminuída em torno de uma ordem de grandeza. A aderência constatada pelos autores foi justificada devido à formação de diferentes compostos entre íons $\mathrm{PO}_{4}{ }^{3-} \mathrm{e} \mathrm{Fe}^{2+}$; para o aço inoxidáveis, estes óxidos são, em sua maioria, solúveis. A aderência do filme foi atribuída à presença dos íons fosfato; os autores indicam ainda que, de fato, a síntese química produz filmes com maiores deslocamentos do $\mathrm{E}_{\text {corr }} \mathrm{e} \mathrm{j}_{\text {corr }}$. De fato, este resultado foi observado nos dados experimentais apresentados.

Outro íon que usualmente é utilizado em síntese eletroquímica para promover aderência é o íon oxalato. Utilizando um meio de síntese com ácido oxálico, Ozyilmaz et al. $\left[{ }^{51}\right]$ depositaram PAni (esmeraldina), por via eletroquímica (voltametria cíclica), sobre aço inox 316L. A corrosão do aço com revestimento foi investigada por meio de ensaios de imersão em meio de $\mathrm{HCl}$, utilizando EIE para determinação dos parâmetros eletroquímicos. Os autores relataram que o oxalato promoveu uma boa aderência do filme de PAni sobre o substrato metálico; entretanto, o fator da porosidade também foi mencionado pelos autores para avaliar a eficiência do revestimento. Filmes depositados a partir de maiores potenciais resultaram em revestimentos mais porosos e que, portanto, apresentaram maior transferência de carga. Contudo, neste processo formou-se uma camada passivadora sobre o aço, que posteriormente aumentou sua proteção. Para filmes sintetizados a menores potenciais finais (na voltametria cíclica), a porosidade obtida foi menor e os autores apontaram a atividade catalítica da PAni sobre a formação do óxido passivador do metal.

Outra forma para diminuir a porosidade do filme, apontada em outro trabalho, é diminuir a velocidade de varredura na voltametria [52]. Os autores realizaram ensaios de polarização em filmes de PAni eletrossintetizados em ácido oxálico, e mostraram valores de potencial de corrosão muito próximos aos obtidos experimentalmente no presente estudo [52]. A corrente de corrosão, entretanto, permaneceu muito parecida àquela do filme sintetizado em meio de fosfato [51], ambas sendo maiores que a corrente obtida nos resultados experimentais deste trabalho. A grande vantagem do filme sintetizado em oxalato é que os parâmetros eletroquímicos apresentaram muito pouca variação mesmo após 240 h em solução diluída de $\mathrm{HCl}$, constatando a aderência do revestimento. 


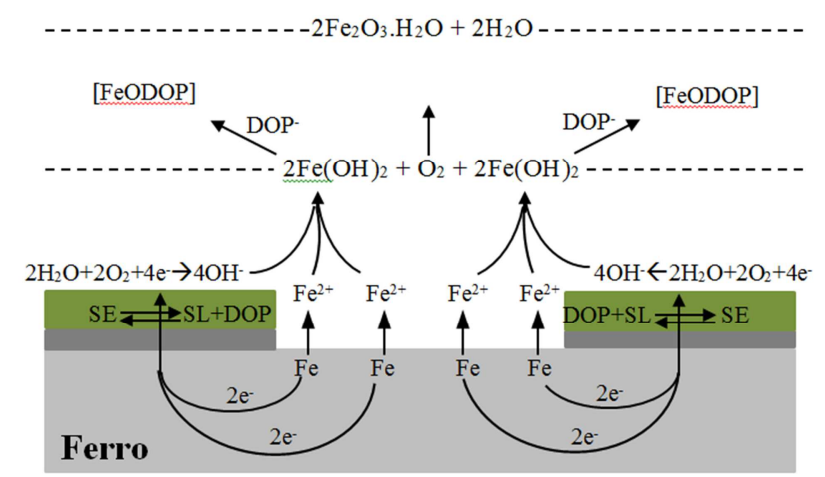

Figura 11 - Mecanismo de passivação do aço pela PAni com presença de defeito no filme (SE: Sal Esmeraldina, SL: Sal Leucoesmeraldina, DOP: ânion dopante) [53].

A habilidade da PAni em proteger pequenas áreas expostas por consequência de riscos no filme foi também demonstrado por Kinlen et al. [53], utilizando a técnica do eletrodo de referência de escaneamento (SRET - Scanning Reference Electrode Technique). Por meio de um mapeamento da superfície de aço carbono 1018 foi possível verificar a regeneração da superfície exposta, corroborando com os resultados dos autores anteriormente mencionados, de que a PAni exerce uma proteção anódica sobre o metal. O mecanismo proposto pelos autores consiste na passivação da área exposta e pela redução do polímero, da forma sal esmeraldina (SE) para sal leucoesmeraldina (SL) e liberação do ânion dopante (DOP); a reação de redução que ocorre é do $\mathrm{O}_{2}$ a íons $\mathrm{OH}^{-}$, em presença de $\mathrm{H}_{2} \mathrm{O}$ (Fig. 11). A eficiência deste processo está intimamente relacionado com a natureza do ânion dopante: dopantes de ácido fosfônico resultaram em melhor passivação do que ácido sulfônico.

Ainda estudando a eficiência de filmes de PAni sobre aço carbono, Li et al. [54] utilizaram EIE para este sistema. Neste trabalho, os autores depositaram PAni sobre amostras de aço e deixaram as diferentes amostras imergidas por $24 \mathrm{~h}$ em soluções de $\mathrm{HCl}$ e $\mathrm{NaCl}$, separadamente. Os revestimentos foram então retirados e as amostras foram deixadas por mais $48 \mathrm{~h}$ em solução de $\mathrm{HCl}$, antes da análise de EIE ser realizada. Os resultados mostraram que a amostra de aço com PAni tratada em $\mathrm{HCl}$ apresentou o melhor resultado. Este resultado foi justificado da seguinte maneira: quando tratada com $\mathrm{HCl}$, a PAni se torna dopada, e deixa a superfície do aço passivada, por isso sua resistência contra a corrosão torna-se maior.

O mecanismo que os autores apresentam é o mesmo que o citado nos artigos já referenciados, ou seja, de uma interconversão entre os estados esmeraldina e leucoesmeraldina, com redução de $\mathrm{O}_{2}$ dissolvido em $\mathrm{H}_{2} \mathrm{O}$ (Fig. 11), ou ainda evolução de $\mathrm{H}_{2}$. Entretanto, novamente a baixa aderência da PAni sobre o aço resultou que, após 48h, o revestimento começou a formar bolhas. Utilizando um revestimento isolante, o filme manteve-se íntegro por 5 dias, porém, depois disto, também apresentou formação de bolhas, 
pois ainda que fosse impermeável, este último revestimento possui somente efeito barreira, não conseguindo se regenerar por efeito redox, como ocorre com a PAni. Assim, uma proteção mais duradoura foi conseguida juntando os dois revestimentos, a PAni como um primer e outra camada isolante sobre o polímero; o sistema com as duas camadas manteve-se íntegro por 20 dias, mostrando que a união dos dois métodos resultou em um efeito sinérgico, e não somente em um efeito aditivo.

Os gráficos de Nyquist apresentaram dois semicírculos (de pequenos diâmetros) para a PAni, um semicírculo para a camada isolante, e um semicírculo com componente difusional (Warburg), para a camada composta por PAni e a camada isolante. Uma vez que há controle difusional no sistema, é possível afirmar que há ocorrência de reações de oxi-redução; o que ocorre, na realidade, é uma diminuição da velocidade com que as espécies corrosivas chegam à superfície do metal, pois o caminho para isto torna-se maior devido à camada isolante, e, portanto, a difusão destas espécies diminui. O resultado é semelhante a introduzir partículas inertes ou inibidores na matriz polimérica. Em geral, para um sistema contendo o metal revestido por uma camada isolante (sem bolhas), o sistema pode ser representado por um circuito equivalente simples, com uma resistência em paralelo com um capacitor, ambos do revestimento, e uma resistência da solução em série com os dois elementos anteriores; o gráfico de Nyquist é um semicírculo. Se o revestimento é eletroativo, como um polímero condutor, o gráfico de Nyquist apresenta dois semicírculos. Os autores concluíram deste trabalho que melhores resultados podem ser obtidos para a PAni se esta for usada como revestimento duplex, com uma camada isolante por cima.

Outros trabalhos nesta mesma direção foram feitos; Schauer et al. [55] recobriram aço carbono com camadas duplex, compostas de um primer comercial a base de PAni e, em seguida, de resina epóxi. Foram realizados ensaios de monitoramento do PCA, ensaios de imersão para monitoramento da resistência de polarização $\left(R_{p}\right)$, testes de aderência, EIE e medidas de condutividade. Com respeito à proteção contra a corrosão, apresentou melhor resultado, como nos trabalhos já citados, as amostras com camada duplex, composta por PAni e resina isolante.

Estudos também foram reportados utilizando PAni em seu estado isolante (base esmeraldina). Mirmohseni et al. [56] utilizaram PAni (base esmeraldina) para proteger superfícies de aço carbono contra a corrosão em ambientes ácido e salino. Os resultados de monitoramento de PCA e polarização potenciodinâmica mostraram uma boa eficiência da PAni em seu estado isolante como recobrimento, superior à resina de policloreto de vinila, usada como comparação. A proteção foi mais efetiva em meio salino que em meio ácido, fato 
este que foi justificado pelos autores devido à alta permeabilidade do polímero ao movimento do próton.

Gasparac et al. [57] propuseram um mecanismo da proteção da base esmeraldina em aço inoxidável 430 em meio de ácido sulfúrico. O PCA mostrou-se mais positivo para aço recoberto com PAni do que para aço sem recobrimento. O PCA da amostra recoberta com polímero mostra, inicialmente, uma queda e, posteriormente, uma rápida recuperação, alcançando novamente valores mais positivos. A influência do $\mathrm{O}_{2}$ neste processo foi estudada, e os resultados mostraram que, em solução de $\mathrm{H}_{2} \mathrm{SO}_{4}$ saturada com $\mathrm{O}_{2}$, a recuperação do PCA era rápida, enquanto que em solução saturada com $\mathrm{N}_{2}$, esta recuperação era lenta; isto demonstrou uma dependência direta do $\mathrm{O}_{2}$ no processo. Se esta recuperação do potencial fosse devido à taxa de repassivação da camada de óxido, a dependência com o $\mathrm{O}_{2}$ não seria esperada. Portanto, os autores concluíram que o aumento do potencial é devido à mudança no estado de oxidação no filme de PAni: os elétrons liberados pela oxidação do ferro provocam a redução do filme de PAni, que se oxida novamente pela presença do $\mathrm{O}_{2}$ dissolvido na água.

Assim, o alto potencial redox positivo da PAni mantém o aço em potencial de passivação, o que resulta em uma baixa taxa de corrosão. Resultados experimentais mostraram que, para que haja proteção de uma superfície, a PAni não precisa, necessariamente, estar em contato direto com aquela superfície. Deng et al. [58] recobriu com PAni um eletrodo de carbono vítreo e o conectou eletricamente com um fio a uma superfície de aço, a qual foi passivada. Isto justifica o fato que a PAni protege uma região exposta do metal, pois os processos de oxirredução do polímero o mantém em um potencial termodinâmico maior que o metal, deixando este último passivado. Assim, se uma parte do filme for removido da superfície, o potencial diminui, mas logo se recupera, assumindo novamente o valor inicial, pois o polímero que restou na superfície mantém toda a área do aço passivada. Se um risco for feito na área do metal sem revestimento, o potencial diminui pelo rompimento da camada de passivação, mas logo se recupera, pela repassivação desta camada por ação da PAni.

Santos et al. [59] mostraram que superfícies de aços carbono e inoxidável foram protegidas pela PAni, em seu estado base esmeraldina. Amostras expostas ao ar apresentaram melhores resultados; este efeito foi atribuído à gradual perda da hidratação da camada pelo polímero, o que resulta em maior resistência do recobrimento. Os recobrimentos mostraramse muito aderentes, e a proteção do aço foi alcançada pela passivação deste, mantida pelo potencial de oxirredução do polímero. 
Pelos trabalhos citados, pode-se observar que, embora as propriedades anticorrosivas da PAni sejam evidentes, a falta de aderência entre metal e polímero é frequentemente citado como um fator limitante para um melhor desempenho do revestimento. Motheo e Bisanha [60] definem adesão como um processo interfacial de duas superfícies suficientemente próximas, unidas por forças físicas e químicas; este processo pode ser de natureza química ou mecânica. No processo mecânico, a adesão é obtida pela penetração do revestimento em defeitos e rugosidade do metal. Já a adesão química é obtida por interações químicas entre o revestimento e o substrato (ligações de hidrogênio, forças de van der Waals, interações de dipolos, etc.). Algumas alternativas para aumentar a aderência entre metal e polímero têm sido descritas na literatura: Moraes et al. [61] utilizaram carboximetil celulose para aumentar a aderência da PAni sobre substrato de aço inoxidável 304. Os autores demonstraram também a eficiência em utilizar tampão fosfato no meio de síntese, obtendo boa aderência para a PAni sintetizada tanto por via química como eletroquímica $\left[{ }^{50,62,63}\right]$.

Para melhorar a aderência entre polímero e o metal, uma alternativa é modificar algumas propriedades do polímero, o que pode ser feito pela inserção de um segundo material na matriz polimérica. Dependendo da natureza e da forma como esta mistura é feita (física ou química), os seguintes tipos de materiais podem ser obtidos: copolímeros (polímero consistindo de duas ou mais unidades repetitivas, obtidas pelo uso de dois ou mais monômeros, que se ligam quimicamente), blendas (mistura física de polímeros, resultando em propriedades diferentes dos polímeros isolados) e compósitos poliméricos (mistura física de polímero com um material inorgânico). Para este último caso, se as partículas tiverem dimensões nanométricas, o material resultante é denominado nanocompósito polimérico [64].

Os materiais que formam um nanocompósito polimérico estão em íntimo contato entre si, chegando quase a nível molecular, resultando em uma mistura com propriedades físicas únicas, diferentes dos materiais iniciais, e diversas possibilidades de aplicação. Assim, diversos materiais podem ser utilizados para formar um nanocompósito com um polímero condutor, como partículas de $\mathrm{SiO}_{2}, \mathrm{SnO}_{2}, \mathrm{CeO}_{2}, \mathrm{CuO}, \alpha-\mathrm{Fe}_{2} \mathrm{O}_{3}, \mathrm{BaSO}_{4}, \mathrm{Al}_{2} \mathrm{O}_{3}, \mathrm{MgO}, \mathrm{PtO}_{2}$, $\mathrm{WO}_{3}$ e $\mathrm{TiO}_{2}$. Dentre as diversas possibilidades possíveis de nanocompósitos, $\mathrm{PAni} / \mathrm{TiO}_{2}$ têm sido sintetizado com sucesso por diversos autores; os procedimentos, em geral, se baseiam na síntese química da PAni em meio ácido a partir de uma solução de anilina com o $\mathrm{TiO}_{2}$ disperso, e posterior adição do agente oxidante (em muitos casos, persulfato de amônio é utilizado) para início da reação. Como o $\mathrm{TiO}_{2}$ está presente no meio reacional, o polímero se forma ao redor das nanopartículas [65-67]. 
Alguns pesquisadores têm empregado nanocompósitos de $\mathrm{PAni} / \mathrm{TiO}_{2}$ para proteção contra a corrosão. Sathiyanarayanan et al. [68] aplicaram um primer a base de um compósito de $\mathrm{PAni} / \mathrm{TiO}_{2}$ disperso em uma resina comercial para proteção contra a corrosão de aço carbono (o polímero foi usado na forma de sal esmeraldina). O comportamento frente à corrosão em meio aquoso contendo cloreto foi verificado mediantes ensaios de monitoramento de PCA, EIE e ensaio de corrosão acelerado em câmara de névoa salina. $\mathrm{O}$ monitoramento do $\mathrm{OCP}$ mostrou que o $\mathrm{TiO}_{2}$, por si só, não conseguiu manter o potencial constante, mas o que se observa é uma queda neste valor. Já quando aplicado como compósito com a PAni, este valor manteve-se aproximadamente constante, próximo a $0 \mathrm{~V}$. Os ensaios de EIE mostraram que o deslocamento da $\mathrm{R}_{\mathrm{p}}$ com o tempo é muito menor para o revestimento de PAni/TiO ${ }_{2}$, com relação ao revestimento com $\mathrm{TiO}_{2}$ somente; ao final de 60 dias, esta diferença chega a ser de aproximadamente 4 ordens de magnitude. Finalmente, ensaios de câmara salina foram feitos com peças de aço revestidas com $\mathrm{TiO}_{2}$ e $\mathrm{PAni} / \mathrm{TiO}_{2}$, e um corte em forma de "X" foi feito em cada amostra. Após 35 dias na câmara, observa-se que na amostra $\mathrm{PAni} / \mathrm{TiO}_{2}$ quase não se vê produtos de corrosão, ao contrário da amostra contendo somente $\mathrm{TiO}_{2}$.

Em outro trabalho, Sathiyanarayanan et al. [69] compararam o desempenho do compósito $\mathrm{PAni} / \mathrm{TiO}_{2}$ com um revestimento similar somente com PAni. Os ensaios de monitoramento do PCA, EIE e ensaio de corrosão acelerado em névoa salina mostraram que, efetivamente, $\mathrm{PAni} / \mathrm{TiO}_{2}$ possui melhor desempenho na proteção contra a corrosão do aço carbono em meio de cloreto. Radhakrishnan et al. [70] utilizaram um nano compósito de $\mathrm{PAni}_{/} / \mathrm{TiO}_{2}$ (polímero como sal esmeraldina) disperso em resina sobre aço carbono. Diferentes quantidades de $\mathrm{TiO}_{2}$ foram testadas; o aumento da quantidade do óxido na matriz polimérica resultou em melhoras significativas nos testes de corrosão. Os ensaios realizados foram monitoramento do PCA, polarização potenciodinâmica, EIE e ensaio de corrosão acelerado em névoa salina. $\mathrm{PAni} / \mathrm{TiO}_{2}$ apresentou boa proteção da superfície de aço contra a corrosão em meio de cloreto.

Mahulikar et al. [71], em trabalho semelhante, mostrou que a camada do compósito $\mathrm{PAni}_{/} / \mathrm{TiO}_{2}$ em resina é hidrofóbica, ao contrário da PAni, que absorve água do meio. Os autores também testaram este revestimento em meios ácido ( $\mathrm{HCl}$ diluído), básico $(\mathrm{NaOH}$ diluído) e salino $(\mathrm{NaCl})$. A melhor proteção foi obtida em ambiente salino neutro e a pior, em ambiente ácido. 


\subsection{Justificativas}

Conforme foi abordado, os aços carbono e inoxidáveis são muito utilizados atualmente como metais para construção dos mais diversos tipos de estruturas. Também é de grande aplicabilidade os processos de soldagem como método de união de materiais, tanto na construção, como na manutenção de estruturas. Entretanto, os metais ferrosos apresentam, em ambientes salinos, problemas de corrosão, em particular a corrosão localizada (mais comumente, a corrosão por pites). Esta corrosão pode ser intensificada na presença de soldas, devido às diferentes alterações estruturais provocadas nos metais pelos processos de fusão ou modificação térmica nas regiões da solda e adjacentes a esta. Tendo em vista que tal problemática requer constante manutenção das estruturas que contém soldas (pois estas podem ainda resultar em sérias consequências devido aos riscos de acidentes), este trabalho propõe o estudo da corrosão nas regiões de solda e adjacentes a esta por diferentes tipos de células e sensores de corrosão e, posteriormente, a síntese, caracterização e aplicação de um revestimento protetor a base de um nanocompósito a base de PAni para proteção contra a corrosão nestas estruturas.

\subsection{Objetivos}

Este trabalho teve por objetivo geral o estudo da corrosão nas regiões de solda, nos aços inoxidáveis 304 e 316, e no aço carbono 1020, com diferentes tipos de células e sensores eletroquímicos. Posteriormente, foram estudadas as condições ideais de síntese de um revestimento protetor a base de um nano compósito constituído de polianilina e nanotubos de $\mathrm{TiO}_{2}$, para proteção contra a corrosão dos aços.

Os objetivos específicos do trabalho são:

Estudo da corrosão nas regiões de solda nos aços inox 304 e 316, e aço carbono 1020, pelos seguintes sistemas eletroquímicos: célula eletroquímica convencional, sensor pontual de corrosão e técnicas eletroquímicas localizadas de análise de corrosão (EIEL e TEVV);

$>$ Síntese e caracterização de revestimento protetor a base de polianilina e nanotubos de $\mathrm{TiO}_{2}\left(\mathrm{PAni} / \mathrm{n}-\mathrm{TiO}_{2}\right)$ sintetizados em diferentes condições;

> Estudo da adição de multicamadas do revestimento sobre aço carbono 1020;

$>$ Aplicação de revestimento protetor sobre aço carbono 1020 e sua solda: estudos de corrosão. 


\section{CAPÍTULO II}

\section{EXPERIMENTAL}

Neste capítulo serão descritos os reagentes, equipamentos e procedimentos experimentais utilizados, assim como os aparatos e parâmetros utilizados para realização das soldagens e ensaios de corrosão. Também serão apresentadas as técnicas de caracterização utilizadas. Experimentos realizados na síntese e caracterização dos polímeros e as montagens experimentais serão detalhados, assim como os tipos de células, sensores e eletrodos utilizados, e seus respectivos procedimentos de limpeza.

\subsection{Reagentes e soluções}

Os reagentes utilizados nos experimentos em geral foram:

- Ácido sulfúrico - $\mathrm{H}_{2} \mathrm{SO}_{4}$ (Mallinckrodt, 98\%)

- Ácido clorídrico - $\mathrm{HCl}$ (Synth, 38\%)

- Anilina $-\mathrm{C}_{6} \mathrm{H}_{5} \mathrm{NH}_{2}$ (Synth PA)

- Persulfato de amônio - $\left(\mathrm{NH}_{4}\right)_{2} \mathrm{~S}_{2} \mathrm{O}_{8}$ (Panreac, PA-ACS)

- Nanotubos de $\mathrm{TiO}_{2}-\mathrm{n}-\mathrm{TiO}_{2}$ (procedimento descrito a seguir)

- Hidróxido de amônio - $\mathrm{NH}_{4} \mathrm{OH}$ (Synth, 28-30\%)

- Cloreto de sódio - $\mathrm{NaCl}$ (Synth, PA-ACS)

- 1-metil-2-pirrolidona - NMP (Aldrich, 99\%)

Todos os reagentes foram utilizados como recebidos, sem nenhuma purificação prévia, com exceção da anilina, que foi destilada à pressão reduzida em presença de pó de zinco antes de seu uso, e acondicionada em ambiente escuro e resfriado.

Os nanotubos de $\mathrm{TiO}_{2}$ foram preparados por tratamento térmico em solução alcalina do $\mathrm{TiO}_{2}$ (fase anatase) em solução de $\mathrm{NaOH} 10 \mathrm{~mol} \mathrm{~L}^{-1}$ a $140^{\circ} \mathrm{C}$ por $24 \mathrm{~h}$, de acordo com procedimento da literatura [72], com modificações. A área superficial específica do material obtido foi de $200 \mathrm{~m}^{3} \mathrm{~g}^{-1}$, com um volume de poro de $0,7 \mathrm{~cm}^{3} \mathrm{~g}^{-1}$.

Os metais utilizados nos experimentos foram os aços inoxidáveis 304 e 316, e aço carbono 1020, com composições químicas nominais conforme especificação dada na tabela 2.

Todos os procedimentos foram realizados em ambiente climatizado, à temperatura de $23 \pm 2^{\circ} \mathrm{C}$, utilizando água ultrapura (exceto quando mencionado) proveniente do sistema de purificação Milli-Q (Millipore), apresentando resistividade de 18,2 $\mathrm{M} \Omega \mathrm{cm}$. 
Tabela 2 - Composição química nominal dos aços inoxidáveis 304 e 316, e do aço carbono 1020 [73]

\begin{tabular}{|c|c|c|c|c|c|c|c|c|}
\hline \multirow{3}{*}{ Tipo de aço } & \multirow{2}{*}{\multicolumn{8}{|c|}{$\%$ dos elementos (em massa) }} \\
\hline & & & & & & & & \\
\hline & $\mathbf{C}$ & Mn & $\mathbf{S i}$ & $\mathbf{P}$ & $\mathbf{S}$ & $\mathrm{Cr}$ & $\mathbf{N i}$ & Mo \\
\hline 304 & 0,08 & 2,0 & 1,0 & 0,045 & 0,03 & $18-20$ & $8,0-10,5$ & -- \\
\hline 316 & 0,08 & 2,0 & 1,0 & 0,045 & 0,03 & $16-18$ & $10-14$ & $2,0-3,0$ \\
\hline 1020 & $0,18-0,23$ & $0,3-0,6$ & -- & 0,040 & 0,05 & -- & -- & -- \\
\hline
\end{tabular}

Foram utilizadas vidrarias diversas, comuns de laboratórios de química, e foram seguidos procedimentos padrões de preparo de soluções, pesagens e nos demais procedimentos analíticos.

\subsection{Células}

Foram utilizados diferentes tipos de células nas etapas de síntese do polímero e nos ensaios eletroquímicos.

\subsubsection{Célula para síntese de polianilina}

Para a síntese química do polímero e do compósito, foi utilizada uma célula de vidro encamisada, com capacidade de aproximadamente $200 \mathrm{~mL}$ (Fig. 12a), com uma tampa de teflon contendo diversos furos (Fig. 12b). A adição do agente oxidante foi feita a partir de um compartimento separado, também encamisado (Fig. 12c). A temperatura foi controlada por meio de um banho termostático, e as sínteses foram feitas sempre com agitação constante (Fig. 12d).

\subsubsection{Célula de corrosão convencional}

As análises de corrosão foram feitas em dois tipos diferentes de células. A primeira foi uma célula convencional feita de acrílico e com um único compartimento de capacidade de, aproximadamente, $100 \mathrm{~mL}$ de solução. Estas análises foram feitas em solução de $\mathrm{NaCl}$, utilizando 3 eletrodos: eletrodo de trabalho, eletrodo de referência e eletrodo auxiliar. A amostra (eletrodo de trabalho) foi prensada contra um anel de borracha (usado para garantir a vedação do sistema), resultando em uma área de análise circular de $1,13 \mathrm{~cm}^{2}$ (Fig. 12). 


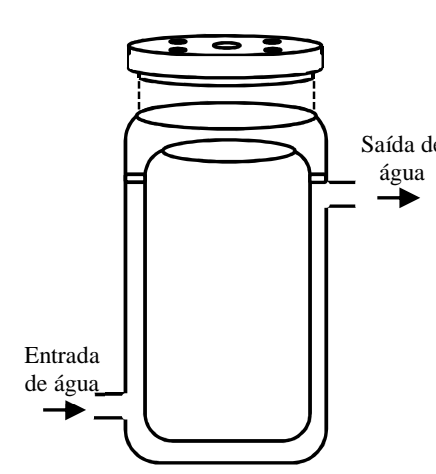

(a)

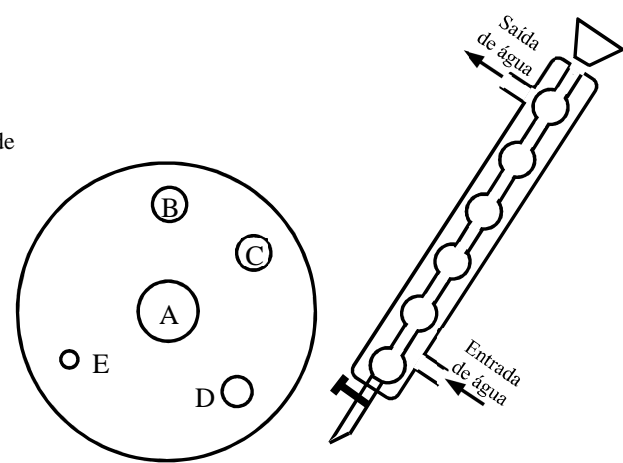

(b)

(c)

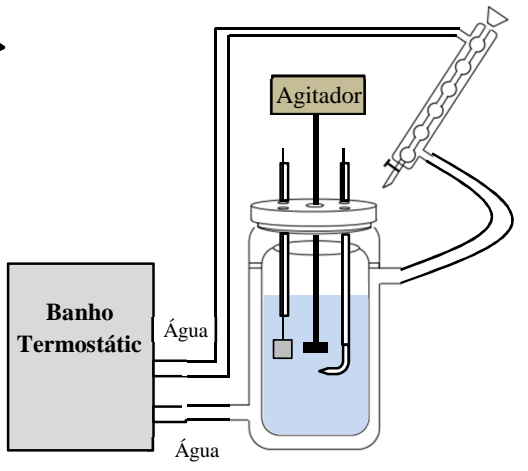

(d)

Figura 12 - Sistema utilizado para síntese química de polímero. (a) Célula encamisada de vidro; (b) tampa de teflon ${ }^{\circledR}$, com furos para entrada de: A - pá para agitação, B - eletrodo de trabalho $(\mathrm{Pt}), \mathrm{C}$ - eletrodo de referência (ECS), D - solução com agente oxidante e E - capilar de vidro com glicerina para medida de temperatura; (c) Reservatório para adição do agente oxidante; (d) Montagem experimental do sistema.

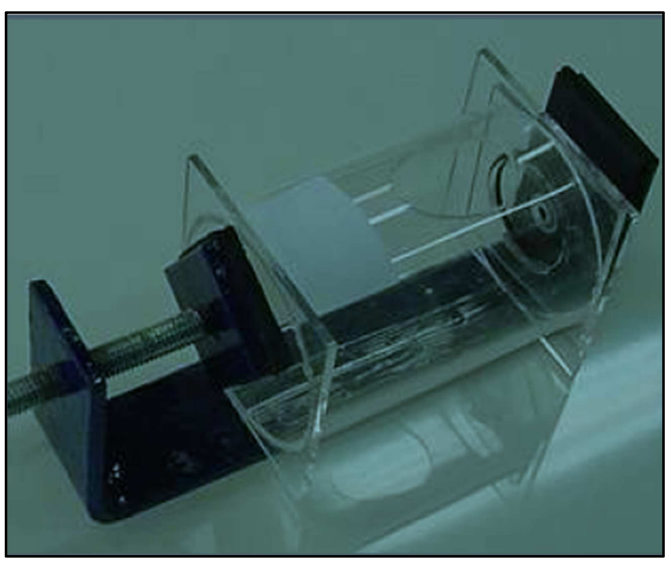

(a)

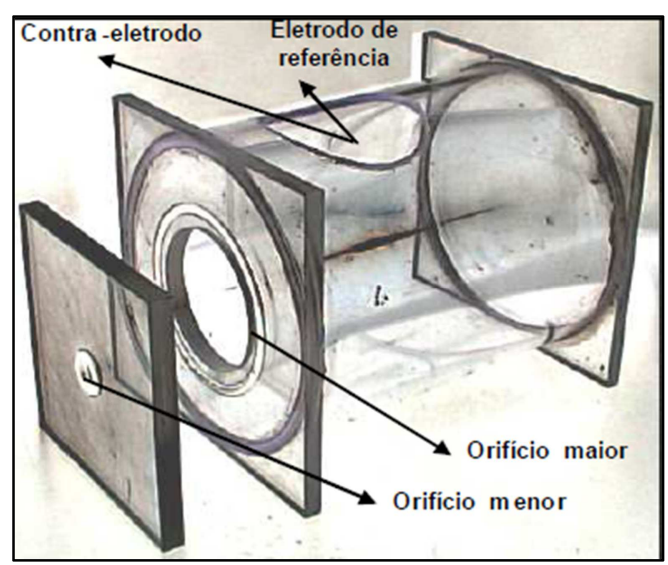

(b)

Figura 13 - Célula usada nos ensaios eletroquímicos de corrosão em meio de cloreto. (a) foto e (b) posição de entrada dos eletrodos.

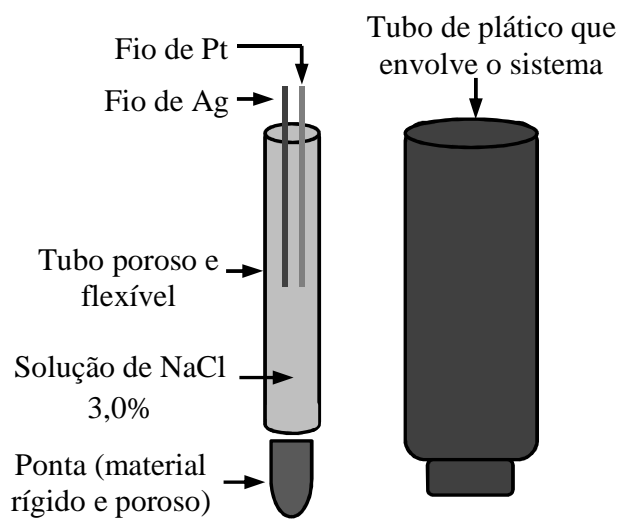

(a)

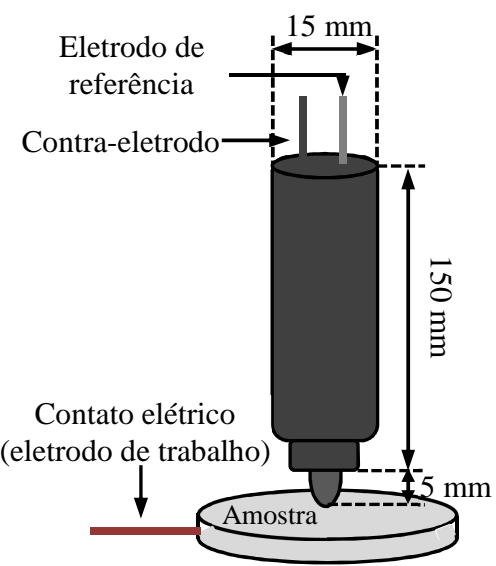

(b)

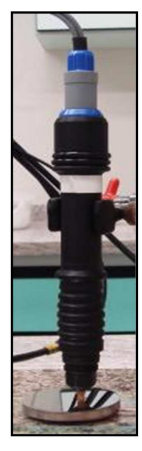

(c)

Figura 14 - Sensor pontual de corrosão (SPC): (a) parte interna e externa; (b) simulação de uma análise; (c) foto do dispositivo. 


\subsubsection{Sensor Pontual de Corrosão (SPC)}

Alguns trabalhos envolvendo micro-células para análise de corrosão em regiões de solda têm sido reportados na literatura, demonstrando o crescente interesse no entendimento da corrosão nestes tipos de materiais utilizando células miniaturizadas [74,75]. Contudo, este número que pode ser encontrado nas bases de dados dentro desta temática ainda é pequeno comparado com os que utilizam células convencionais de corrosão. Assim, uma célula de corrosão com dimensões reduzidas foi utilizada, consistindo de um fio de Ag (eletrodo de referência) e um fio de Pt (eletrodo auxiliar) colocados em uma das extremidades de um tubo contendo um polímero sólido poroso e flexível. Este tubo possuía em sua outra extremidade uma ponta de material poroso sólido, mais rígido que o tubo, que fazia contato direto com o eletrodo de trabalho, em uma área estimada de $0,00785 \mathrm{~cm}^{2}$. Todo o conjunto continha solução aquosa de $\mathrm{NaCl} 3,0 \%$, e se encontra dentro de um tubo de plástico rígido, que protegia o sistema com os eletrodos e a solução (Fig. 14). Este sistema foi denominado sensor pontual de corrosão (SPC).

\subsubsection{Análises de Corrosão Localizadas}

As análises de corrosão localizadas, também chamadas de localizadas, são medidas consecutivas feitas sobre diferentes pontos de uma amostra; permitem assim obter um mapeamento da superfície analisada. As técnicas são classificadas de acordo com o tipo de sinal medido. Assim, se este sinal for a impedância do sistema, a técnica denomina-se EIEL (Espectroscopia de Impedância Eletroquímica Localizada). Se o sinal for a corrente de corrosão, a técnica é denominada TEVV (Técnica do Eletrodo Vibratório de Varredura). Existem ainda outras técnicas de análises localizadas, mas por não terem sido utilizadas neste trabalho, não foram mencionadas. De modo geral, são utilizados sensores (denominados probes) que ficam a uma pequena distância da superfície da amostra, e que são deslocados por um braço mecânico (controlado por um software). Os princípios físicos envolvidos nestas técnicas são diferentes das análises globais, pois não há contato entre o sensor e a amostra. Devido a estes princípios físicos, o material a ser analisado precisa ter pequena área geométrica de análise e estar envolto por uma superfície isolante. Por meio destas técnicas, é possível fazer um mapeamento da superfície (medidas bidimensionais, abrangendo uma área), uma linha (unidimensional) ou, simplesmente, uma única medida pontual, como em uma análise global. Os resultados dos mapeamentos foram apresentados na forma de figuras com 
uma escala de cores indicando os valores do parâmetro medido (impedância, para EIEL, e densidade de corrente, para TEVV).

As análises de EIEL foram feitas em solução de $\mathrm{NaCl} 1,0 \mathrm{mmol} \mathrm{L}^{-1}$ (concentração previamente otimizada), utilizando-se uma estação eletroquímica Uniscan 370, acoplada a uma unidade de controle de varrimento, ligados a um potenciostato Solartron 1287A com analisador de resposta de frequência Solartron 1250 (Fig. 15). O microeletrodo era composto por um eletrodo duplo, feito de um anel concêntrico a um fio, posicionados a $2 \mathrm{~mm}$ da superfície da amostra. Um sinal de $15 \mathrm{mV}$ foi aplicado ao eletrodo ao microeletrodo. $\mathrm{O}$ eletrodo de referência utilizado foi ECS, mantido distante da superfície analisada (parte do metal, não da resina), e como eletrodo auxiliar foram utilizadas duas redes de fios de Pt, também mantidos longe do eletrodo de trabalho.

Para as análises pela TEVV foi utilizado um sensor (microeletrodo) constituído por um fio de platina e irídio recoberto com uma camada isolante lateral. A ponta que fica exposta fica a $100-200 \mu \mathrm{m}$ da superfície analisada, e é recoberta por negro de platina, a fim de diminuir a impedância e o ruído, pelo aumento da área superficial; a ponta do microeletrodo possuía diâmetro de 40-50 $\mu \mathrm{m}$. A vibração do eletrodo é feito por meio de um dispositivo piezoelétrico, e seu potencial é medido com relação a um eletrodo estacionário de calomelanos saturado. As análises pela TEVV foram realizadas em solução de $\mathrm{NaCl} 5,0.10^{-2}$ mol L ${ }^{-1}$, utilizando um sistema comercial da Applicable Electronics (PA, USA) com um microscópio óptico acoplado, controlado pelo programa ASET (Sciencewares) (Fig. 16).

\subsection{Eletrodos}

Nesta parte estão descritos os eletrodos utilizados como trabalho, referência e auxiliar; ainda, está também descrita a montagem do eletrodo duplo, utilizado nas análises de corrosão localizadas.

\subsubsection{Eletrodos de platina}

Foram utilizados como eletrodos auxiliares, na forma de chapas de dimensões de, aproximadamente, $2,5 \times 2,5 \mathrm{~cm}$, soldado em fio de platina e conectado eletricamente a um fio de cobre dentro de um capilar de vidro (Fig. 17a). 


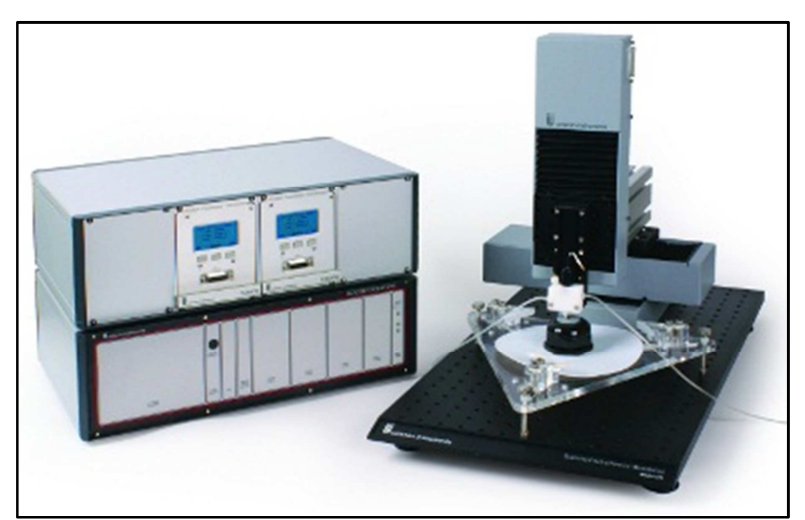

(a)

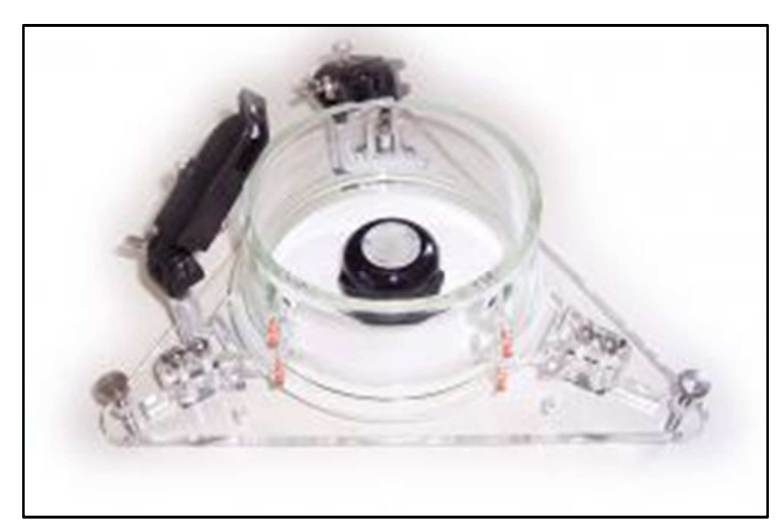

(b)

Figura 15 - (a) Equipamento utilizado nas análises por EIEL; (b) detalhe do compartimento onde o eletrodo duplo é fixado para adição da solução de trabalho [76].

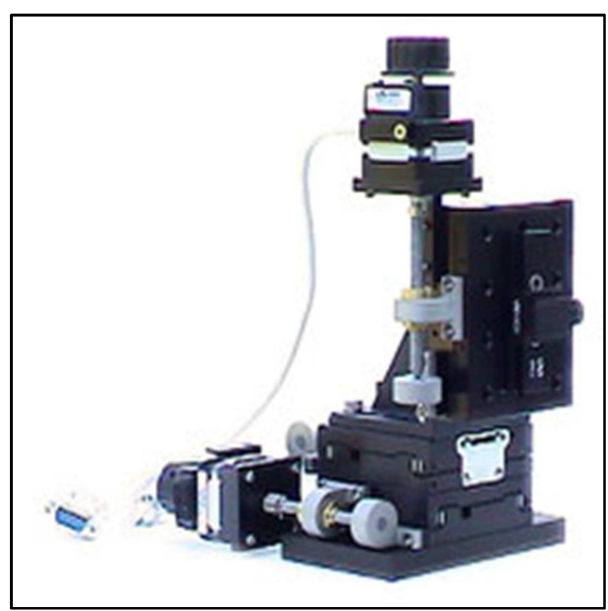

(a)

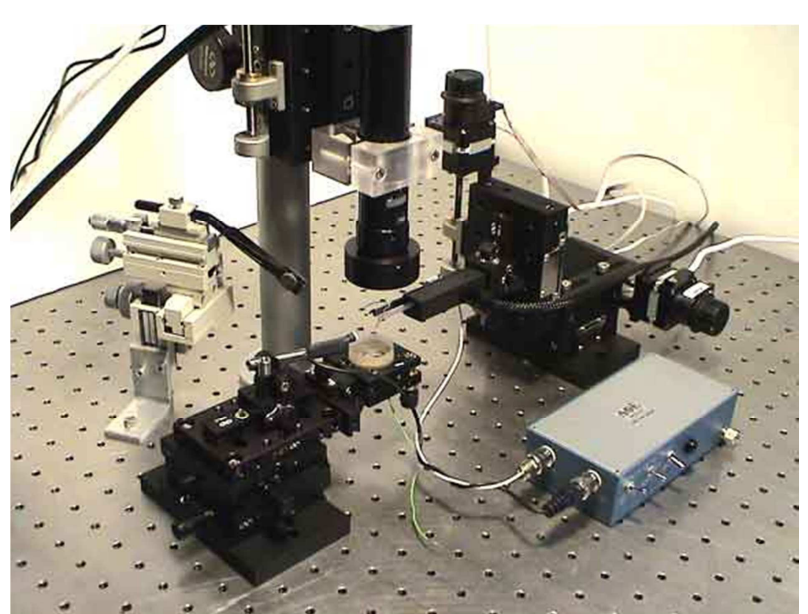

(b)

Figura 16 - Equipamento utilizado nas análises pela TEVV. (a) imagem do equipamento e (b) detalhe do microscópio óptico acoplado [77].

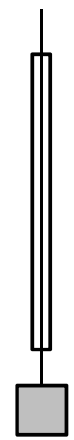

(a)

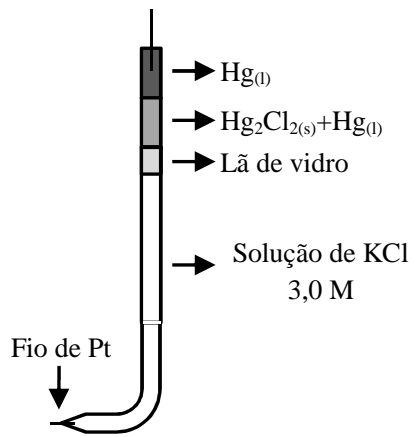

(b)

Figura 17 - (a) Eletrodo auxiliar de Pt e (b) eletrodo de referência de calomelanos saturado.

\subsubsection{Eletrodo de calomelanos saturado}

Foi utilizado como eletrodo de referência; é constituído por $\mathrm{Hg}$ líquido em contato com um amálgama constituído de $\mathrm{Hg}_{2} \mathrm{Cl}_{2}$ macerado com o $\mathrm{Hg}$, dentro de um capilar de vidro 


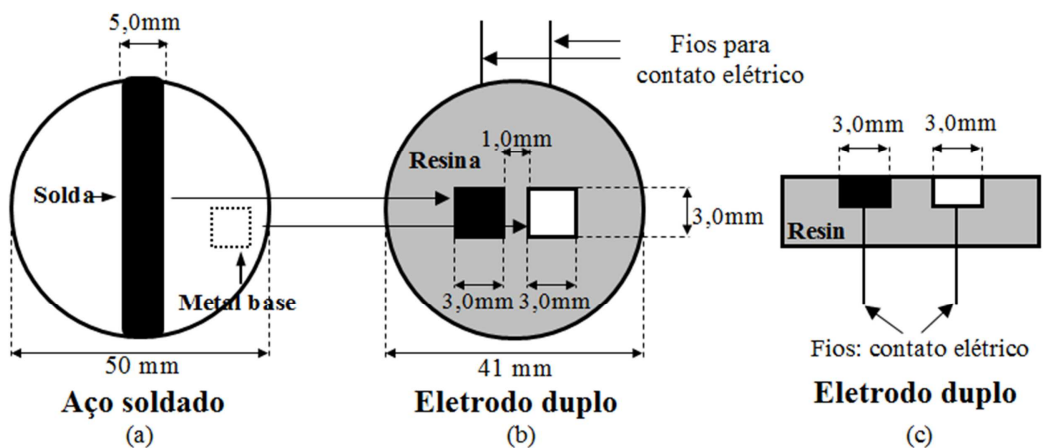

Figura 18 - Montagem experimental do "eletrodo duplo": (a) regiões de solda cortada da amostra de aço soldado; (b) e (c) amostras embutidas em resina.

fechado com lã de vidro. Um capilar de Luggin contendo um fio de Pt soldado na ponta e preenchido com solução de $\mathrm{KCl}$ 3,0 M foi utilizado para evitar contaminação da solução do eletrodo com a de trabalho (Fig. 17b).

\subsubsection{Eletrodo duplo}

Para os ensaios de corrosão localizadas, uma montagem específica com os eletrodos de trabalho foi utilizada. Dois pedaços com dimensões de 3,0x3,0mm de amostras de aço carbono 1020 foram cortadas, sendo um da região da solda e outro do metal base (Fig. 18a). Dois fios foram soldados às amostras (com solda de $\mathrm{Pb}-\mathrm{Sn}$ ) para estabelecer contato elétrico, e elas foram embutidas em resina epóxi, com uma distância de 1,0mm entre si. Esta montagem foi denominada de eletrodo duplo (Fig. 18b e 18c).

\subsection{Preparação de eletrodos}

As amostras de aços inox e carbono foram utilizados como discos de $40 \mathrm{~mm}$ de diâmetro e, aproximadamente, 5,0 $\mathrm{mm}$ de espessura. Eles foram preparados de diferentes maneiras, dependendo do objetivo de seu uso.

Para os ensaios de corrosão, os eletrodos de aço foram utilizados como discos com 40 mm de diâmetro. Foi feito um polimento mecânico com lixas d'água (\#100 à 600 mesh, passando por lixas intermediárias), desengraxe (em etanol), lavagem (com $\mathrm{H}_{2} \mathrm{O}$ ) e secagem com um soprador térmico. O eletrodo duplo foi preparado desta mesma maneira.

Para os ensaios metalográficos, os discos de aço de $40 \mathrm{~mm}$ de diâmetro foram embutidas em resina epóxi e posteriormente foram polidas com lixas d'água (\#100 à 1500 mesh, passando por lixas intermediárias). Em seguida, as amostras foram espelhadas, utilizando um tecido de polimento com suspensão aquosa de alumina 0,5 micra, em uma 
politriz. As amostras foram então desengraxadas com etanol (em sonicador), lavadas com $\mathrm{H}_{2} \mathrm{O}$ e secas com um soprador térmico.

\subsection{Procedimentos de limpeza}

Todas as vidrarias e peças de Teflon $^{\circledR}$ foram limpas, inicialmente, com uma lavagem com água e detergente. Após enxague (em água de torneira), os utensílios foram imersos em solução ácida de $\mathrm{KMnO}_{4}$ por cerca de $12 \mathrm{~h}$, e posteriormente foram enxaguados com solução ácida de $\mathrm{H}_{2} \mathrm{O}_{2}$, para remoção dos óxidos de manganês depositados nas paredes das vidrarias e do teflon ${ }^{\circledR}$. As peças foram enxaguadas com abundante quantidade de $\mathrm{H}_{2} \mathrm{O}$ para remoção dos resíduos de peróxido de hidrogênio, e em seguida, com $\mathrm{H}_{2} \mathrm{O}$ quente (exceto para vidrarias com maior precisão volumétrica, como balões volumétricos e pipetas). Mais um enxágue foi feito com $\mathrm{H}_{2} \mathrm{O}$ à temperatura ambiente e secagem final em estufa (exceto para vidrarias com maior precisão volumétrica).

As células para ensaios de corrosão (de acrílico) foram lavadas com detergente e enxaguadas com água da torneira e, posteriormente, com abundante quantidade de $\mathrm{H}_{2} \mathrm{O}$ destilada.

Os eletrodos de platina foram limpos por meio da exposição em chama oxidante e posterior imersão (a quente) em $\mathrm{H}_{2} \mathrm{O}$ (flame annealing).

Os eletrodos de referência de calomelanos saturado foram mantidos em circuito aberto junto com outros eletrodos da mesma natureza, em uma solução de $\mathrm{KCl} 3,0 \mathrm{~mol} \mathrm{~L}^{-1}$. Antes do uso, os eletrodos foram enxaguados com abundante quantidade de $\mathrm{H}_{2} \mathrm{O}$ e cuidadosamente secos com papel macio (somente com um leve contato do papel ao eletrodo, para evitar atrito nas paredes do eletrodo).

\subsection{Técnicas}

As várias técnicas utilizadas para caracterização e ensaios eletroquímicos estão descritas nesta seção.

\subsubsection{Soldagem TIG}

O processo de soldagem TIG (Tungsten Inert Gas), também conhecido como GTAW (Gas Tungsten Arc Welding), foi selecionada devido a não alterar a composição química do 


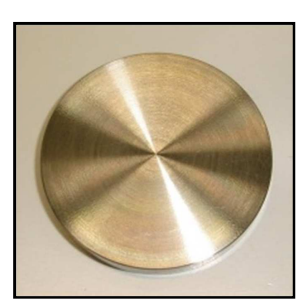

(a)

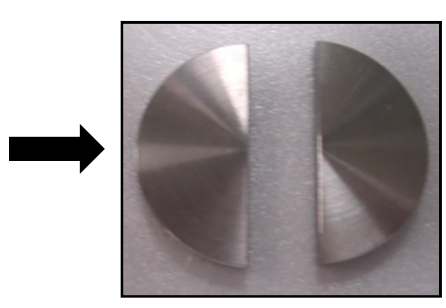

(b)

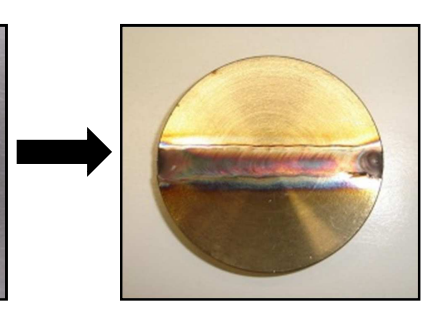

(c)
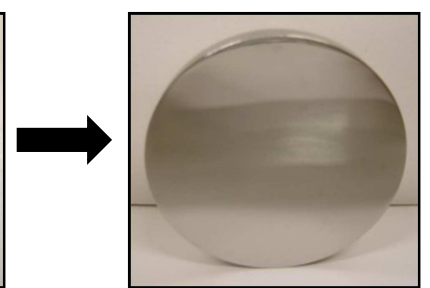

(d)

Figura 19 - Preparação das amostras de aço soldadas: (a) amostra inicial, e após: (b) após corte; (c) união pela aplicação de solda; (d) polimento.

metal e às características da solda resultante (obtenção de soldas de alta qualidade, minimização da extensão da zona termicamente afetada, boa resistência mecânica e baixa susceptibilidade a rachaduras na zona termicamente afetada); não foi utilizado nenhum metal de enchimento.

Para a soldagem, as peças de aço em forma de discos, com $42 \mathrm{~mm}$ de diâmetro (Fig. 19a) foram cortadas ao meio; as duas novas faces resultantes deste corte foram torneadas para ficarem planas (Fig. 19b), e em seguida, unidas novamente utilizando a soldagem TIG (Fig. 19c). Foi utilizado um equipamento de solda TIG MILLER, modelo Syncrowave 200, com gás argônio, utilizando correntes de solda de 15, 35, 70 e 100 A. As deformações nas peças causadas pela soldagem foram corrigidas por torneamento das mesmas, até que estas estivessem perfeitamente planas. Em seguida, foi feito o polimento na amostra, de acordo com o procedimento já descrito (Fig. 19d).

\subsubsection{Monitoramento da corrosão}

Os ensaios para monitoramento da corrosão são de grande importância, pois permitem acompanhar, de forma sistemática e/ou quantitativa, o processo de degradação de determinado material, e, desta forma, avaliar a eficiência de revestimentos protetores em relação aos materiais sem recobrimento. Podem ser realizados desde a inspeção visual, qualitativa, até ensaios eletroquímicos e analíticos, de forma a quantificar e caracterizar o processo de corrosão em cada etapa.

\subsubsection{Análises globais}

As medidas aqui denominadas "globais" são aquelas que foram feitas utilizando a célula eletroquímica convencional, e que, portanto, analisam uma determinada área do 
eletrodo. As medidas aqui referidas são medidas eletroquímicas de polarização potenciodinâmica, monitoramento do PCA, EIE e $\mathrm{R}_{\mathrm{p}}$. É interessante utilizar uma medida global quando se deseja obter como resultado uma média de uma determinada superfície. Para superfícies que apresentam pontos de heterogeneidades, como ligas metálicas (em que pequenas concentrações locais de elementos de liga podem resultar em resultados eletroquímicos diferentes da média em uma região maior), uma análise global, envolvendo uma área relativamente grande, praticamente anula estes efeitos locais, e o resultado expressa a média de toda a região analisada.

\subsubsection{Análises Pontuais}

As análises pontuais foram aquelas feitas com o sensor pontual de corrosão (SPC). Ela utiliza os mesmos princípios físico-químicos das análises globais, e o tratamento de dados também é feito da mesma maneira. Difere somente no valor da área analisada, bem menor do que a área nas medidas globais. As análises eletroquímicas que podem ser realizadas com o SPC são as mesmas feitas na célula convencional. O diferencial em utilizar este tipo de célula é que áreas pequenas podem ser analisadas, possibilitando verificar efeitos de corrosão pontuais, e não uma média (medida global) de uma região maior da superfície. Além disso, é um dispositivo portátil, dispensando a necessidade de corte da amostra para realização da análise; desta forma, também pode ser utilizado para medidas em campo, com auxílio de um multímetro ou computadores e potenciostatos portáteis. A análise com o SPC foi feita por meio do contato direto da ponta do dispositivo com a amostra. Um contato elétrico (fio de cobre) foi colocado na amostra (eletrodo de trabalho) para conectá-lo ao potenciostato. Nos intervalos em que não estava sendo utilizado, a ponta do SPC ficava imerso em solução de $\mathrm{NaCl} 3,0 \%$.

\subsubsection{Análises Localizadas}

As técnicas de corrosão localizadas, EIEL e TEVV, permitem caracterizar processos eletroquímicos locais de superfícies com heterogeneidades. Enquanto as técnicas de corrosão globais e locais permitem apenas uma análise em apenas uma região da amostra, as técnicas de corrosão localizadas permitem mapear uma superfície, por meio de sucessivas medidas em diferentes pontos da amostra, previamente configurados a partir do software. Desta forma, são obtidas informações de cada ponto medido, resultando em um mapa que demonstra o perfil da 
superfície, e não um único valor que represente esta como um todo. Além disso, são técnicas não destrutivas, permitindo fazer o monitoramento da amostra na solução por períodos prolongados. Os resultados, entretanto, apresentam diferenças qualitativas entre as regiões analisadas, pois não é possível confinar a corrente pontualmente na área de interesse para se obter dados quantitativos precisos [78]. A espectroscopia de impedância eletroquímica localizada, EIEL mede a impedância em cada ponto da amostra para obter, ao final, um mapa da amostra.

A técnica do eletrodo vibratório de varredura foi inicialmente explorada por Bluh e Scott [79], sendo posteriormente melhorada por Jaffe e Nuticelli [80]. Mais tarde, Isaacs e Scheffey $[81,82]$ introduziram medidas bidimensionais e microeletrodos com apenas a ponta exposta e isolamento lateral, o que resultou em medidas mais uniformes. A primeira aplicação da técnica em corrosão utilizando eletrodos vibratórios foi feita por Isaacs [83,84]. O sensor mede o campo elétrico da solução pontualmente, o qual é convertido em valores de corrente por meio da resistividade da solução. Enquanto que pela técnica de polarização potenciodinâmica se obtém um único dado de potencial e corrente de corrosão para toda a superfície analisada, a técnica de TEVV permite obter um mapeamento das correntes de corrosão ao longo da superfície, além de mostrar as áreas anódicas e catódicas. Assim, esta técnica é muito informativa para superfícies em que a corrosão não está distribuída de maneira uniforme, sendo por isso muito útil para soldas e revestimentos protetores [78].

\subsubsection{Análises eletroquímicas de corrosão}

Estas análises permitem obter dados quantitativos para monitorar a evolução de um processo de corrosão, sendo que as que foram utilizadas neste trabalho foram: polarização potenciodinâmica, resistência de polarização e espectroscopia de impedância eletroquímica.

\subsubsection{Polarização potenciodinâmica}

Por meio da técnica de polarização potenciodinâmica é possível fazer o levantamento da curva de polarização do metal dentro da solução de ensaio (normalmente, uma solução aquosa de $\mathrm{NaCl}$ ). A curva de polarização é feita por meio de uma varredura linear em um determinado intervalo de potenciais, a baixas velocidades de varrimento; estabelece-se, assim, uma corrente anódica $\left(i_{a}\right)$ e outra catódica $\left(i_{c}\right)$. O potencial em que a magnitude das correntes anódica e catódica são iguais é denominado potencial de corrosão $\left(\mathrm{E}_{\mathrm{corr}}\right)$. O potencial aplicado 


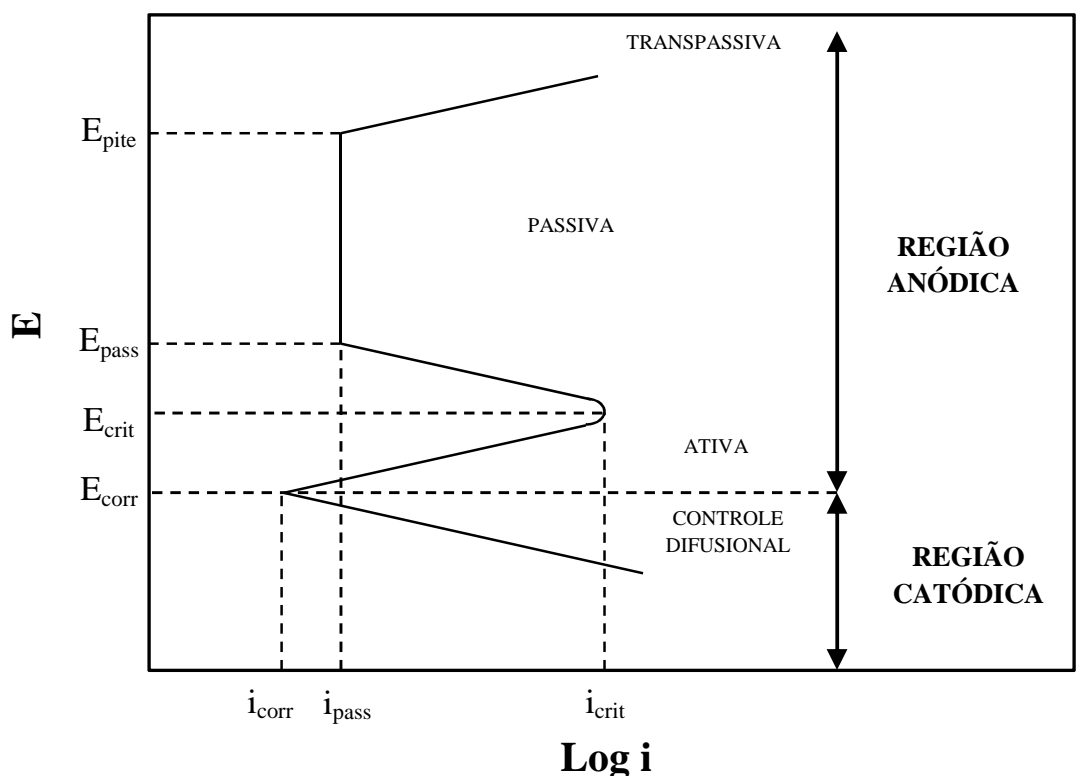

Figura 20 - Representação de E em função de log i para análise de corrosão por extrapolação das retas de Tafel. [85].

e a corrente registrada são apresentados na forma de um gráfico do logarítimo da corrente em função do potencial.

A curva de polarização completa é obtida quando os ramos anódico (varrimento no sentido de potenciais mais positivos que o $\mathrm{E}_{\text {corr }}$ ) e catódico (varrimento no sentido de potencias mais negativos que o $\mathrm{E}_{\text {corr }}$ ) são unidos; a corrente obtida no $\mathrm{E}_{\text {corr }}$ é denominada corrente de corrosão $\left(i_{\text {corr }}\right)$. Dividindo este valor pela área do eletrodo, obtém-se a densidade de corrente de corrosão $\left(\mathrm{j}_{\text {corr }}\right)$. Deste gráfico, quatro regiões podem ser observadas: a região de controle difusional no ramo catódico, e as regiões ativa, passiva e transpassiva no ramo anódico (Fig. 20).

A formação da camada de óxido sobre a superfície é observada na região passiva, resultando em uma diminuição da $i_{\text {corr }}$, a qual fica constante, com baixas taxas de corrosão. $\mathrm{O}$ potencial a partir do qual ocorre ruptura do filme passivador e a formação de pites é iniciada, é denominado potencial de pite $\left(\mathrm{E}_{\mathrm{p} i t e}\right)$. Esta região é caracterizada por um aumento brusco na densidade de corrente (embora nem todos os materiais apresentem esta região bem definida) $[3,86]$.

\subsubsection{Potencial de circuito aberto}

As medidas de PCA são feitas a partir da medida do potencial do eletrodo de trabalho versus um eletrodo de referência. Por se tratar de baixas correntes, não é necessário utilizar 
um eletrodo auxiliar. As medidas permitem analisar a variação dos potenciais em determinada solução, podendo relacioná-lo, posteriormente, com a eficiência de um recobrimento e o tipo de proteção obtida (catódica ou anódica).

\subsubsection{Resistencia de polarização}

A resistência de polarização é um método que não altera as propriedades do eletrodo (não destrutivo), pois o intervalo de potencial é pequeno para que alterações significativas na amostra sejam observadas. É feito mediante uma varredura linear entre $-20 \leq \mathrm{E}_{\text {corr }} \leq 20 \mathrm{mV}$, a baixas velocidades de varredura (em geral, a mesma utilizada na polarização potenciodinâmica). $\mathrm{O}$ valor da $\mathrm{R}_{\mathrm{p}}$ pode ser obtido pelo coeficiente angular da reta, e é diretamente proporcional à eficiência de um revestimento que atua contra a corrosão.

\subsubsection{Espectroscopia de Impedância Eletroquímica}

Na técnica de impedância eletroquímica (ou método de impedância ac), um potencial de corrente alternada (ao invés de corrente contínua, como ocorre na polarização potenciodinâmica) com diferentes valores de frequência é aplicado; é comumente conhecido como espectroscopia de impedância eletroquímica.

Esta técnica permite determinar processos de eletrodos e interfaces, como $R_{p} e$ capacitância da dupla camada em uma mesma medida. Além disso, é um método que não perturba as propriedades do eletrodo, pois a medida é feita no potencial estacionário $\left(\mathrm{E}_{\mathrm{corr}}\right)$ do eletrodo, permitindo assim que várias medidas sejam feitas para um mesmo eletrodo em diferentes tempos. A limitação desta técnica, entretanto, é que por meio dela não é possível determinar os coeficientes das retas de Tafel.

Os dados podem ser são apresentados de diferentes formas. Os mais comuns são pelo gráfico de Nyquist (elementos reais da impedância, $\mathrm{Z}_{\mathrm{r}}$, como resistores, versus elementos imaginários, $Z_{\mathrm{im}}$, como capacitores e indutores, Fig. 21a) e os gráficos de Bode (módulo da impedância versus frequência e ângulo de fase versus frequência, Fig. 21b). As diferentes representações da análise são complementares em termos da forma com que as informações são apresentadas. 


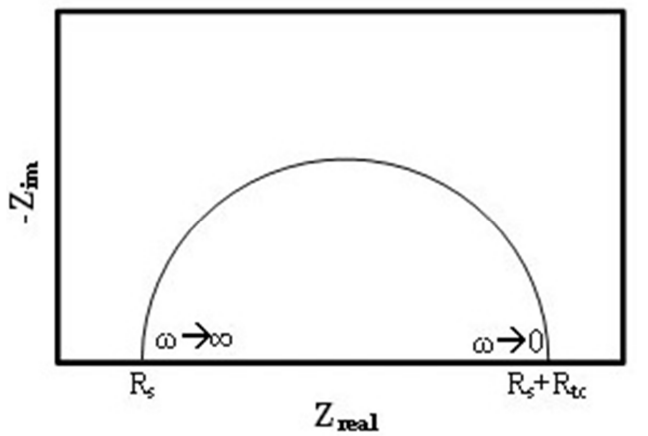

(a)

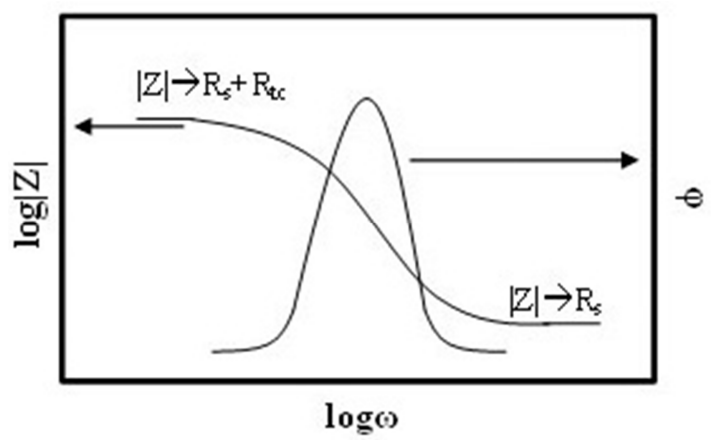

(b)

Figura 21 - Gráficos de apresentação de dados de impedância eletroquímica: diagramas de (a) Nyquist e (b) de Bode.

No diagrama de Nyquist as componentes real e imaginária da impedância são graficadas, mas a frequência não é indicada pelos eixos; no diagrama de Bode, a frequência é apresentada como sendo um dos dois eixos, mas as componentes da impedância não são indicadas. O tratamento dos dados pode ser feito de diferentes maneiras, sendo que um dos mais utilizados é o de simulação por meio de um circuito elétrico que seja capaz de representar o sistema eletroquímico em questão. Nesta análise, um circuito equivalente é proposto com elementos como resistores, capacitores, elemento de fase constante (indica comportamento capacitivo) e Warburg (indica controle difusional), dispostos em série ou paralelo. Um algoritmo simula a curva de impedância referente a este circuito, que deve ser idêntica à curva experimental. Cuidados devem ser tomados nesta análise, pois diferentes circuitos podem resultar em uma mesma curva simulada, de forma que o sistema eletroquímico em questão deve ser cuidadosamente analisado para que haja coerência entre a simulação e o sistema real $[3,86,87]$.

\subsubsection{Microscopia}

As técnicas de microscopia permitem a visualização da superfície da amostra em diferentes graus de ampliação. Dependendo da necessidade desta ampliação, diferentes técnicas de microscopia são utilizadas: microscopia óptica (MO), eletrônica de varredura (MEV), eletrônica de tunelamento e de força atômica, por exemplo. A MO oferece menor ampliação (até 2000x), devido à limitação no comprimento de onda da radiação eletromagnética. As microscopias eletrônicas oferecem maiores ampliações, pois o comprimento de onda de um feixe de elétrons pode ser sensivelmente menor do que o de uma radiação eletromagnética. Serão apresentadas somente as MO e MEV, pois foram as únicas utilizadas. 


\subsubsection{Microscopia óptica}

A microscopia óptica é uma técnica muito útil para análises metalográficas, observação da morfologia da corrosão em metais e degradação de revestimentos protetores, com ampliações que podem chegar a até 2000 vezes. Os principais componentes de um microscópio óptico são a fonte de luz e dois sistemas de lentes convergentes, a ocular e a objetiva; o sistema de luz pode estar localizado acima ou abaixo do plano da amostra.

As lentes objetivas (são aquelas que ficam próximas da amostra) devem apresentam pequena distância focal, e formam uma imagem real e aumentada da amostra analisada. As oculares (são aquelas que ficam próximas ao olho de quem está fazendo a análise) são lentes que funcionam como uma lupa, fornecendo uma imagem virtual e ampliada da imagem real formada na objetiva. Estas lentes são dispostas nas extremidades de um cilindro oco (coluna do microscópio), que se aproxima ou se afasta da amostra para que seja obtida a focalização da amostra. O poder de ampliação da lente é obtido pelo produto entre a ampliação linear da objetiva e da ocular. Maiores ampliações são obtidas quando a distância focal da objetiva for pequena; isto resulta, entretanto, em uma maior aproximação da lente à amostra e, consequentemente, uma diminuição da área visualizada [88]. Estas análises foram feitas utilizando um microscópio óptico invertido LEICA modelo DMILM, com uma câmera acoplada LEICA DFC295.

\subsubsection{Microscopia eletrônica de varredura}

Embora muito útil, a MO fica limitada a ampliações até 2000 vezes devido a efeitos de difração que dependem do comprimento de onda da radiação incidente. Um microscópio eletrônico de varredura, assim como outros tipos de microscopia eletrônica, utiliza um feixe de elétrons ao invés de fótons, resolvendo o problema de limitação da resolução dos microscópios ópticos. Pela teoria da dualidade partícula-onda proposta por De Broglie (1925), o comprimento de onda de um elétron é função de sua energia, que pode ser comunicada a uma nova partícula por meio de um campo elétrico acelerador, gerando elétrons de comprimento de onda extremamente curto e, portanto, poder de resolução muito altos. Ao ser incidida por um feixe de elétrons (denominados elétrons primários), a amostra emite uma série de radiações: elétrons secundários, retroespalhados, raios-X, elétrons Auger, fótons, dentre outros. A formação das imagens é feita a partir da focalização dos elétrons em campos eletrostáticos ou magnéticos sobre pontos da amostra. Resulta-se, assim, em imagens com ampliações de até 300.000 vezes ou mais, e profundidade de até $10 \mathrm{~nm}$. A análise pode 
fornecer rapidamente informações sobre a morfologia de superfícies, além de possibilitar uma aparência tridimensional da imagem devido à profundidade de campo.

Os tipos de feixes mais utilizados para análise de imagens são os elétrons secundários e retroespalhados. Dentre estes dois, o mais utilizado é o feixe de elétrons secundários, pois ele fornece uma imagem de topografia de superfície de amostra e gera imagens de alta resolução. É resultado de elétrons ejetados da amostra pela colisão dos elétrons do feixe primário. Os elétrons retroespalhados formam uma imagem característica de variação de composição, e é resultante de colisões elásticas do feixe primário com a amostra. O feixe de elétrons (de pequeno diâmetro) é incidido sobre a amostra, ponto a ponto, por meio de uma varredura de linhas [89]. As fotomicrografias de MEV foram obtidas a partir de um equipamento ZEISS LEO 440 (Cambridge, England) com detector de elétrons secundários OXFORD (model 7060), operando com feixe de elétrons de 20kV. Imagens obtidas com elétrons retroespalhados foram obtidas utilizando o detector Four Quadrant Backscaterred Electron Detector Type 400.

Como as análises de MEV são feitas com base em feixes de elétrons, é necessário que a amostra seja condutora. Por isso, antes das análises as amostras foram recobertas com um filme fino de ouro, depositado pelo método de sputtering. Neste trabalho as amostras foram recobertas com 10nm de ouro em um metalizador Coating System BAL-TEC MED 020 (BAL-TEC, Liechtenstein) e mantidas em dessecador até o momento da análise.

\subsubsection{Técnicas espectroscópicas}

Espectroscopia refere-se à ciência que estuda a interação de diferentes tipos de radiação com a matéria. Inicialmente, as radiações estudadas eram exclusivamente as eletromagnéticas, mas hoje este campo foi estendido a outras formas de energia, como ondas acústicas e feixes de partículas (íons e elétrons); as técnicas espectroscópicas se baseiam nas medidas das variações da intensidade da radiação que interage com a amostra [90]. Embora não estejam diretamente ligadas às análises de corrosão, estas técnicas são muito importantes para caracterizar as amostras quanto à sua composição química, tanto qualitativa como quantitativamente.

\subsubsection{Espectroscopia de energia dispersiva de raios $\mathrm{X}$}

Os microscópios eletrônicos de varredura podem ser equipados com detectores de raios-X $(E D X)$, que detectam a radiação $X$ resultante da interação de elétrons primários com a superfície da amostra, permitindo análises químicas qualitativas e semi-quantitativas na região 
micrométrica de incidência do feixe de elétrons. Entretanto, como a área de análise é pequena, ela pode não corresponder necessariamente à composição média da amostra, caso esta não seja homogênea. Além disso, esta análise é superficial, de modo que a composição do interior da amostra também não é levada em conta [89]. Neste trabalho foi utilizado um equipamento EDX LINK ANALYTICAL, (Isis System Series 200), com detector SiLi Pentafet, janela ultrafina ATW II (Atmosphere Thin Window) de resolução de $133 \mathrm{eV}$ à 5,9 keV, acoplado ao microscópio eletrônico. Utilizou-se padrão de Co para calibração, feixe de elétrons de $20 \mathrm{kV}$, distância focal de $25 \mathrm{~mm}$, corrente de 2,82A e $\mathrm{I}_{\text {probe }}$ de 950pA. Assim como nas análises de $\mathrm{MEV}$, as amostras também precisam ser condutoras, de forma que foram recobertas com ouro antes das análises.

\subsubsection{Espectroscopia na região do infravermelho por transformada de Fourrier}

A espectroscopia na região do infravermelho (IV) é uma técnica espectroscópica baseada na absorção de radiação infravermelha por moléculas, a qual provoca variações no momento de dipolo elétrico da ligação química por consequência de seu movimento rotacional ou vibracional, já que esta espectroscopia não é energeticamente suficiente para promover transições eletrônicas. O processo de vibração das moléculas é quantizado, porém a cada mudança de nível de energia vibracional, estão associados diversos níveis de energias rotacionais. Por isso, os espectros se apresentam como bandas, e não como linhas discretas. A região do infravermelho se encontra no espectro eletromagnético, aproximadamente, entre os comprimentos de onda de $750 \mathrm{~nm}$ até quase $1,0 \mathrm{~mm}$, porém a faixa mais utilizada neste tipo de

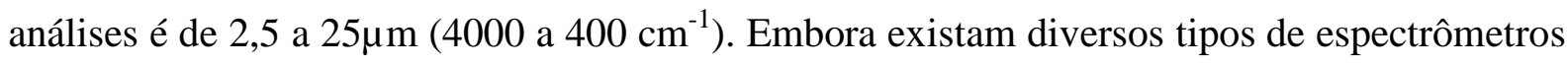
na região do infravermelho, os que possuem maior sensibilidade são aqueles com sistema de detecção com transformada de Fourrier. Este sistema possui um interferômetro de Michelson, o qual gera como resultado um gráfico denominado interferograma, formado pela soma de todas as ondas de diferentes amplitudes e frequências que chegam ao interferômetro, e possui todas as informações espectrais da amostra. As vantagens deste tipo de sistema é que o instrumento possui poucos componentes ópticos e não necessita de fenda, permitindo a chegada de maior intensidade de radiação e, desta forma, aumentando a relação sinal/ruído, melhorando a precisão e exatidão em termos de comprimentos de onda e, por fim, todos os sinais alcançam a fonte ao mesmo tempo, reduzindo o tempo de análise [90].

As análises de espectroscopia IV foram feitas para caracterizar a PAni e $\mathrm{PAni} / \mathrm{TiO}_{2}$ sintetizados a diferentes temperaturas. Para fazer as análises, o material foi macerado em 
presença de $\mathrm{KBr}$, na proporção aproximada de 1/100 (em massa), e foi confeccionada uma pastilha para realizar a análise.

\subsubsection{Espectroscopia na região do ultravioleta-visível}

$\mathrm{Na}$ espectroscopia nas regiões do ultravioleta (200-400nm) e visível (400-700nm), UV-vis, a absorção da radiação por moléculas promove transições eletrônicas em grupos denominados cromóforos, que são grupos que contêm elétrons que sofrem transições de baixa energia $\left(\pi \rightarrow \pi^{*}\right.$ e $\left.n \rightarrow \pi^{*}\right)$ e, portanto, apresentam resposta nos espectros de UV-vis. São cromóforos, por exemplo, grupos carbonila, aldeído, amino, éster, éter, entre outros. Embora outras transições sejam possíveis (como aquelas que envolvem orbitais $\sigma$ ), a energia envolvida nestas transições é muito alta, e a radiação não possui energia suficiente para que a transição ocorra. Embora as transições eletrônicos ocorram em comprimentos de onda discretos, o gráfico resultante é em forma de bandas (com um máximo no comprimento de onda da transição), pois níveis vibracionais e rotacionais estão associados a cada nível eletrônico [90].

As análises por espectroscopia UV-vis foram feitas a partir de uma solução de PAni (desdopado) em NMP. A esta solução foi adicionada uma gota de $\mathrm{HCl} \mathrm{5,0} \mathrm{mol} \mathrm{L}{ }^{-1}$ para dopar o polímero, e a análise foi repetida com o polímero dopado. Nesta análise, o polímero com n$\mathrm{TiO}_{2}$ não foi analisado porque o óxido não é solúvel no solvente do polímero, causando dispersão da radiação. As análises foram feitas em um espectrômetro dispersivo Varian Cary modelo 2315, utilizando uma cubeta de quartzo com caminho óptico de $1 \mathrm{~cm}$, utilizando uma solução de NMP isenta de polímero como referência.

\subsubsection{Ensaios de corrosão acelerados: câmara de névoa salina}

Ensaios de corrosão acelerada são experimentos que aceleram o processo de corrosão de uma amostra. Desta forma, estes ensaios simulam, em tempo reduzido, o que aconteceria com a amostra se esta fosse exposta a um longo período em atmosfera real. Dentre os ensaios de corrosão acelerados existentes, está o ensaio em câmara de névoa salina, que consiste em uma câmara fechada que simula uma atmosfera marinha, por meio de um spray de solução de cloreto. No experimento realizado, as peças ficaram expostas a um spray de uma solução de $\mathrm{NaCl}$ em uma câmara de névoa salina BASS USC 00/2002. Os experimentos foram realizados de acordo com a norma ASTM B117-11 [91]. As amostras foram expostas a um spray de uma solução de $\mathrm{NaCl} 5,0 \%$ (com pH entre 6,5 e 7,2) com ar comprimido, à temperatura de 
$35 \pm 1^{\circ} \mathrm{C}$. Os ensaios permitem observar a eficiência dos diferentes tipos de revestimentos; as amostras foram verificadas periodicamente, e caracterizadas por observação visual (registradas por meio de imagens feitas com câmera fotográfica) e MO, para acompanhar a evolução da corrosão nas mesmas.

\subsection{Métodos: síntese química de PAni e PAni/n-TiO 2}

A síntese dos polímeros e compósitos foram feitas no sistema previamente apresentado para este fim (Fig. 12); a síntese foi feita em meio ácido. A anilina, utilizada como monômero, foi previamente destilada sob pressão reduzida em presença de pó de zinco (agente redutor), e acondicionada em geladeira, protegida da exposição da luz. O agente oxidante utilizado na síntese foi $\left(\mathrm{NH}_{4}\right)_{2} \mathrm{~S}_{2} \mathrm{O}_{8} 0,1 \mathrm{~mol} \mathrm{~L}^{-1}$, e a proporção molar entre monômero e agente oxidante na síntese foi 1:1. As sínteses foram realizadas às temperaturas de 0 e $25^{\circ} \mathrm{C}$, controladas por um banho termostático, e sob constante agitação. As variações do potencial e da temperatura foram registradas em função do tempo. As medidas de potencial foram feitas utilizando um eletrodo indicador de Pt e um eletrodo de referência de calomelanos 3,0\%, conectados a um multímetro, e as medidas de temperatura foram registradas a partir de um termopar. Na síntese da PAni, o agente oxidante (dissolvido no mesmo meio que a anilina) foi adicionado à solução do monômero lentamente. A síntese prosseguiu sob agitação por 1,5h. Após finalizada a síntese, a suspensão contendo o polímero foi filtrada à vácuo, e o sólido foi lavado com abundante quantidade de $\mathrm{H}_{2} \mathrm{O}$, para remoção de oligômeros. A secagem foi feita em estufa à vácuo, à cerca de $30^{\circ} \mathrm{C}$, por $24 \mathrm{~h}$ (polímero dopado). A desdopagem do polímero foi feita deixando-se o mesmo em solução $0,1 \mathrm{~mol} \mathrm{~L}^{-1}$ de $\mathrm{NH}_{4} \mathrm{OH}$, sob agitação por $24 \mathrm{~h}$. Após desdopado, o polímero foi filtrado, lavado com $\mathrm{H}_{2} \mathrm{O}$ e seco em estufa à vácuo, nas mesmas condições que o polímero dopado. A síntese da $\mathrm{PAni} / \mathrm{n}-\mathrm{TiO}_{2}$ foi feita adicionando-se $0,5 \mathrm{~g}$ de n- $\mathrm{TiO}_{2}$ na solução de anilina em ácido. A suspensão foi deixada por $1 \mathrm{~h}$ em sonicador, para promover boa dispersão do óxido, e em seguida adicionada na célula de reação. Os procedimentos posteriores desta síntese foram os mesmo realizados para a PAni. 


\section{CAPÍTULO III}

\section{RESULTADOS E DISCUSSÕES}

O presente capítulo foi dividido em 3 seções, cada qual com um aspecto abordado no estudo. Na primeira seção é apresentada a caracterização inicial dos aços utilizados, o estudo das soldas aplicadas com diferentes correntes e, também, o efeito da aplicação de um recobrimento de PAni na proteção contra a corrosão dos aços e de suas soldas. Na segunda seção, um estudo sobre a corrosão de soldas em aços é apresentado, baseado em técnicas eletroquímicas globais e localizadas. Na terceira seção estão descritas a síntese, caracterização e aplicação de um revestimento protetor contra a corrosão, feito a base de $\mathrm{PAni} / \mathrm{n}-\mathrm{TiO}_{2}$. Os testes de corrosão foram realizados sobre aço carbono 1020, pois foi o que apresentou maior corrosão dentre os aços analisados. Por fim, o revestimento que apresentou melhores características foi aplicado sobre peças metálicas de aço carbono contendo solda e as análises realizadas com técnicas localizadas.

\subsection{Caracterização da influência da aplicação de solda em aços inoxidáveis e carbono e efeito do recobrimento de PAni na proteção contra a corrosão}

Na presente seção será inicialmente apresentada a caracterização metalográfica dos aços inoxidáveis 304 e 316, e do aço carbono 1020, com soldas feitas a diferentes correntes. Posteriormente, um estudo comparativo entre a célula convencional de corrosão e o sensor pontual de corrosão (SPC) será apresentado com a descrição da análise de adequação deste último sistema em relação ao sistema convencional. Utilizando o SPC, análises de corrosão foram feitas nas regiões dos cordões de solda, e a corrosão entre esta região e o seu metal base foi analisada. Por fim, um recobrimento de PAni foi depositado sobre os aços inoxidáveis e suas soldas, para verificar a proteção contra a corrosão oferecida por este tipo de revestimento.

\subsubsection{Caracterização metalográfica de soldas em aços inoxidáveis 304 e 316}

Após a soldagem, as amostras de aços inoxidáveis apresentaram aspectos semelhantes; as espessuras dos cordões de solda obtidos variaram de 1 a $5 \mathrm{~mm}$, à medida que a corrente de solda foi aumentada (Fig. 22). Após o polimento e espelhamento, a região do cordão de solda 


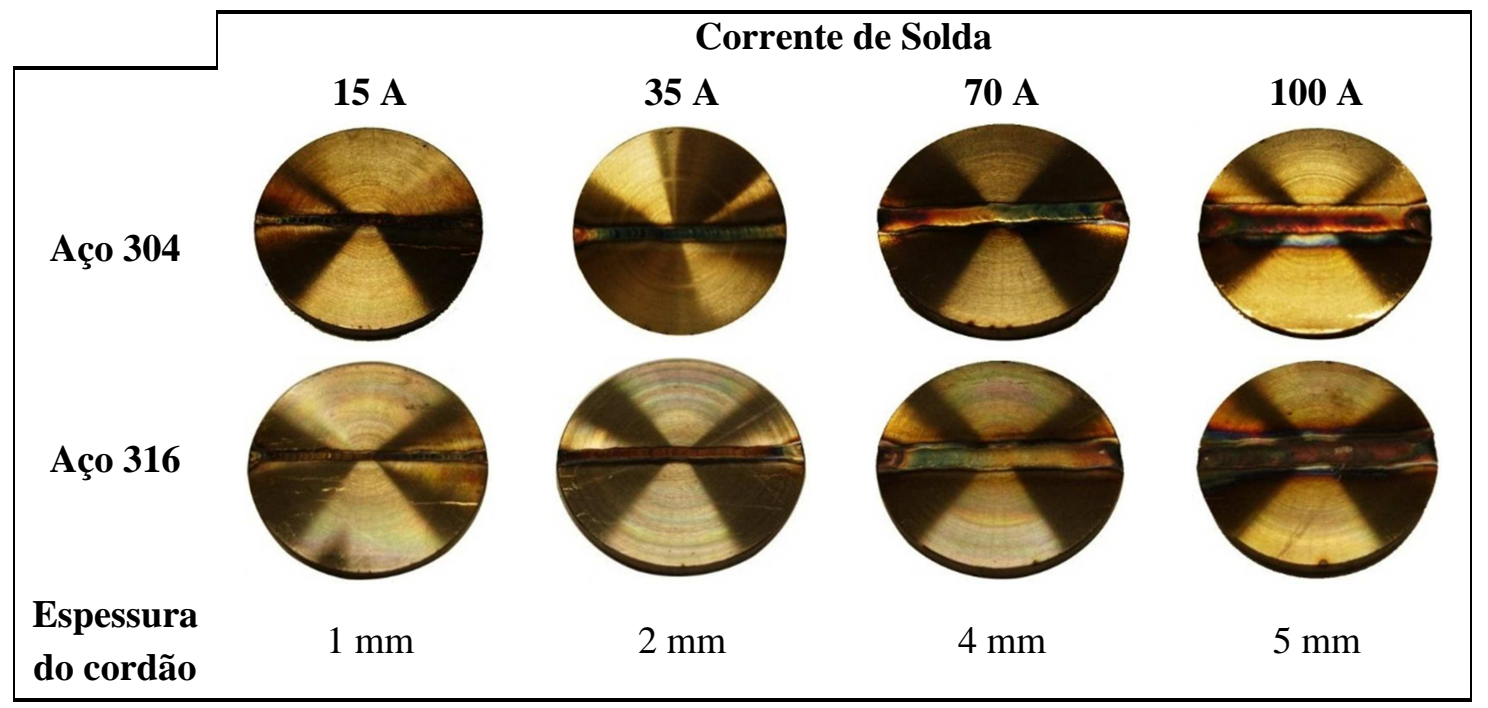

Figura 22 - Aços 304 e 316 soldados a partir de diferentes correntes de solda.

passou a não ser mais visível a olho nu, voltando a ser visível somente após ataque químico. As imagens da microestrutura dos aços 304 e 316 obtidas por microscopia óptica (Fig. 23) apresentaram aspectos semelhantes (para as mesmas regiões). Os dois aços, embora possuam algumas diferenças na composição química, apresentaram a mesma estrutura cristalina (austenítica).

$\mathrm{Na}$ zona de solda houve uma alteração da estrutura cristalina, passando a ser observado uma fase ferrítica, caracterizada (pela análise das microscopias ópticas) por uma estrutura mais compacta, denominada dendritos. Em geral, nos aços que contêm cromo (como nos aços inoxidáveis), pode ocorrer a precipitação de carbetos ricos deste elemento nos limites de grão da Zona Afetada pelo Calor (ZAC), o que prejudica as propriedades mecânicas das juntas. Assim, no processo de fusão dos aços inoxidáveis ocorreu alteração da estrutura cristalina inicial austenítica $(\gamma-\mathrm{Fe})$ para ferrítica $(\delta$-Fe). No processo de solidificação, a fase $\delta$ ferrítica tende a retornar para seu estado $\gamma$-Fe inicial, em um processo controlado difusionalmente; isto significa que a temperatura e, consequentemente, a velocidade de resfriamento, é um fator fundamental na estrutura cristalina resultante do processo de soldagem. 


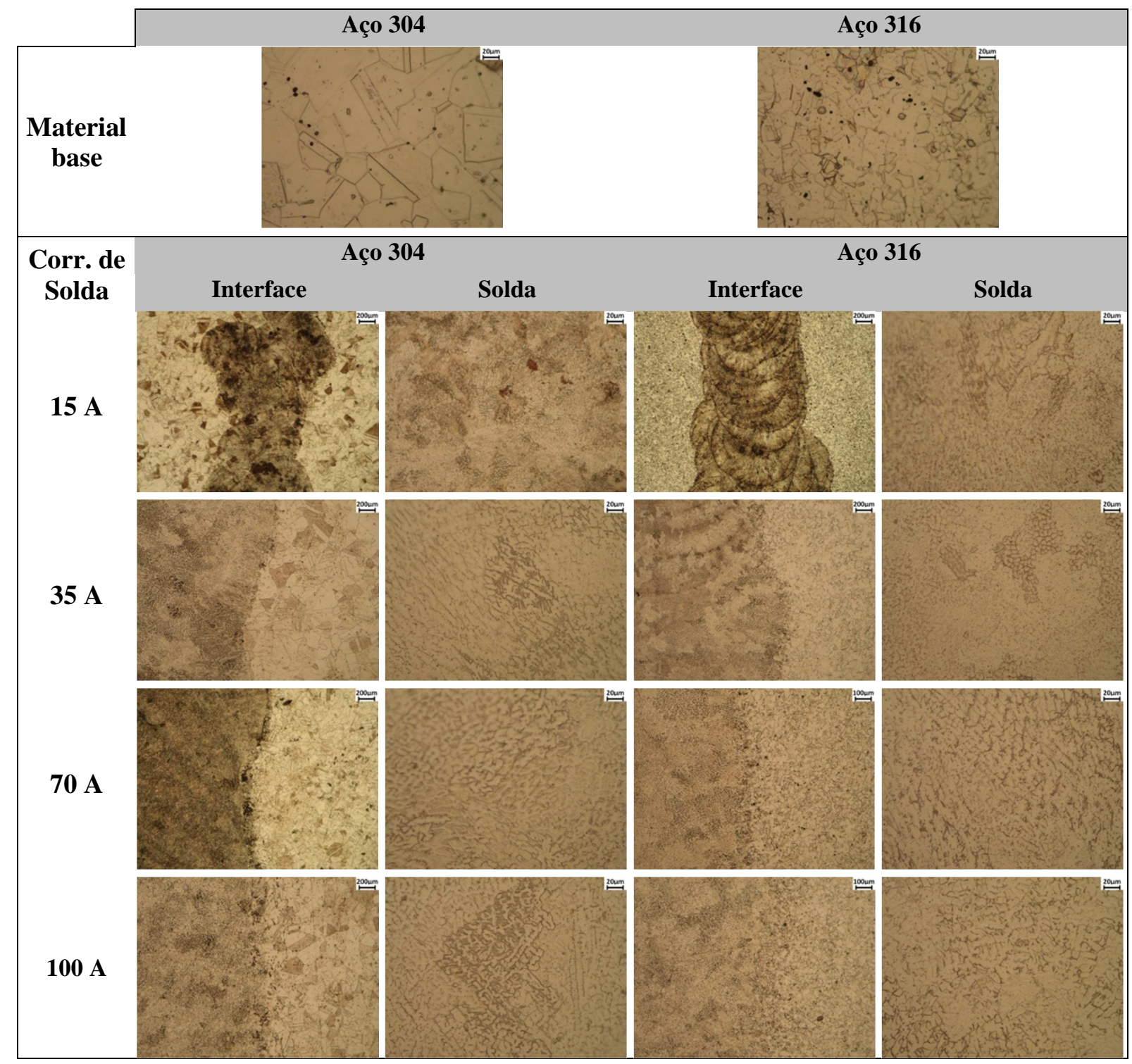

Figura 23 - Microestruturas dos aços 304 e 316 com diferentes correntes de solda, obtidas por MO, após ataque químico com solução de água-régia.

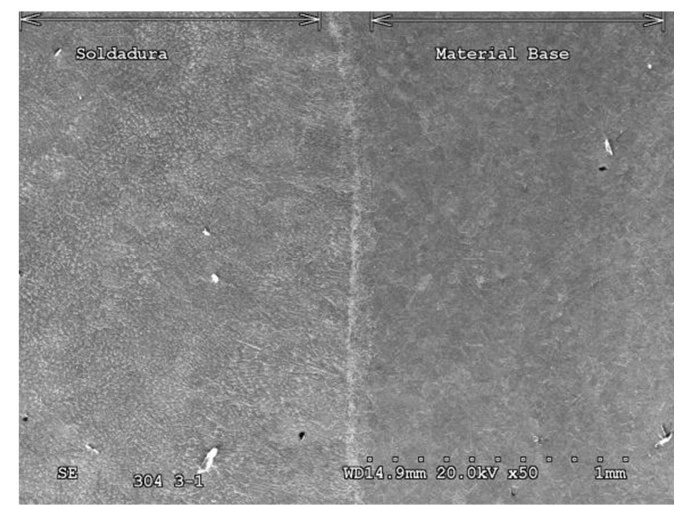

(a)

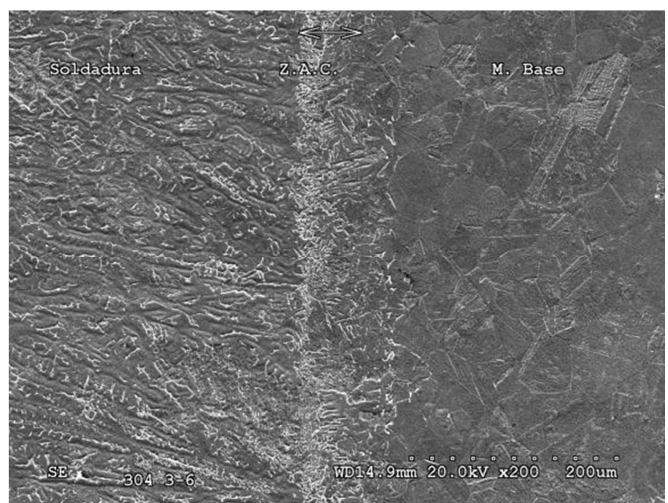

(b)

Figura 24 - Microestrutura do aço inox 304 com solda (corrente: 100 A), obtidas por MEV, após ataque químico com solução de água-régia. (a) Interface (solda e material base) e (b) solda, ZAC e material base. 


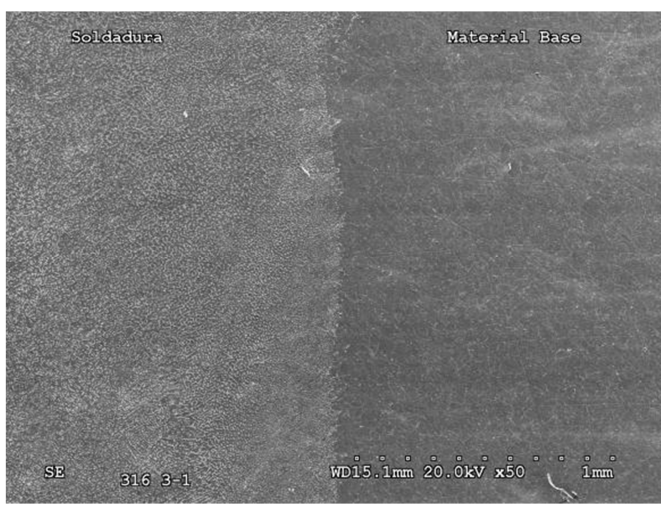

(a)

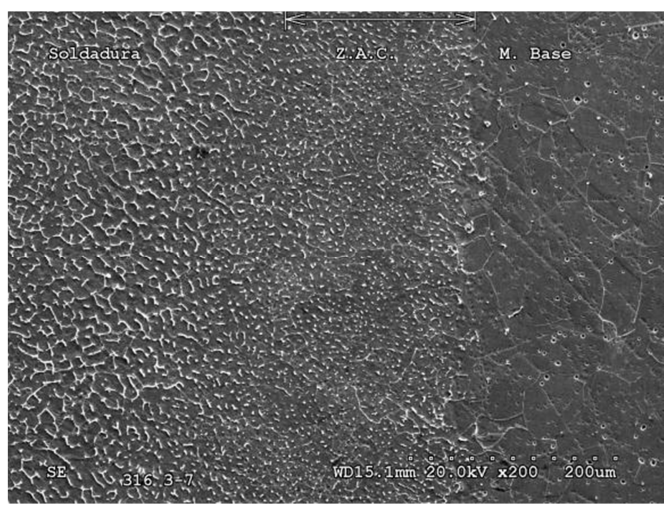

(b)

Figura 25 - Microestrutura do aço inox 316 com solda (corrente: 100 A), obtidas por MEV, após ataque químico com solução de água-régia. (a) Interface (solda e material base) e (b) solda, ZAC e material base.

No caso da soldagem TIG, a solidificação ocorre rapidamente, ocasionando uma condição de não equilíbrio entre as fases cristalinas. Como resultado, a fase ferrítica não retorna totalmente para a fase austenítica, culminando em uma superfície formada por uma distribuição de fase ferrítica (fase secundária) em uma matriz austenítica [92]; por isso são observadas tais alterações nas microestruturas dos aços. $\mathrm{O}$ aumento da corrente de solda intensifica este processo, e a solda obtida a partir de correntes mais altas adquire uma estrutura de dendritos. Tal efeito pode ser observado nos dois aços inoxidáveis estudados. Além da zona de solda, outra região encontrada em metais soldados é zona afetada pelo calor (ZAC); ela está localizada entre a zona de fusão e o metal base. Esta região pôde ser observada a partir de imagens de microscopia eletrônica de varredura do metal (Fig. 24 e 25).

Pela análise das microscopias ópticas foi possível diferenciar as regiões com e sem solda; por meio das microscopias eletrônicas de varredura foi possível verificar as duas regiões anteriores, além da zona afetada pelo calor (ZAC), que corresponde a uma região de transição entre a solda e o metal base. Os ciclos térmicos a que os materiais estão sujeitos durante a soldagem podem causar micro segregação dos elementos químicos, precipitação de fases secundárias, presença de porosidade, fratura durante a solidificação, crescimento do grão na ZAC e perda de material por vaporização [93]. As imagens de microscopia óptica e de MEV, entretanto, não revelaram a presença de rachaduras e porosidade nas soldas dos aços 304 e 316.

Yan et al.[93], utilizando soldagem TIG em aço 304, também não observaram a presença de rachaduras na região de solda. Pelas microscopias óptica e eletrônica foi possível ainda determinar diferenças quanto a região de solda nos dois aços estudados. No aço 304, a 
fase $\gamma$-Fe (região de solda) apresenta-se como "dendritos esqueléticos" (estrutura semelhante a um esqueleto), enquanto que no aço 316, ela se apresenta como dendrito vermicular. Pelas imagens de MEV, observa-se que na ZAC estas estruturas ainda estão presentes, porém ficam mais compactas, permitindo desta forma distinguir esta região da zona de fusão e do metal base. O aumento da corrente de solda nos dois casos provocou uma melhor definição das estruturas nesta região (dendrítica vermicular para o aço 304 e esquelética no aço 316 - Fig. 24 e 25, respectivamente). A estrutura esquelética em regiões de solda de aço 316 também foi observada por Lu et al. [94]; segundo os autores, altas taxas de calor (e baixas taxas de resfriamento) durante a soldagem são prejudiciais, pois aumentam a segregação de elementos, principalmente do cromo, na ZAC. Assim, observa-se que o aumento da corrente de solda nos aços inoxidáveis 304 e 316 resulta em maior alteração na estrutura cristalina da região de solda, e pode facilitar a corrosão na ZAC devido à segregação dos elementos nesta zona.

Destas análises, observa-se que a alteração estrutural fica claramente demonstrada. Esta alteração pode gerar uma diferença no potencial químico desta região com relação a seu metal, e como consequência, o processo de corrosão nas soldas é diferente do que em seu metal base. Por isso, o estudo da corrosão destas soldas em meio de cloreto será posteriormente apresentado, já que o ânion $\mathrm{Cl}^{-}$pode provocar ataques localizados em aços inoxidáveis, provocando formas agressivas de corrosão, como a corrosão puntiforme. Adicionalmente, a diferença no potencial químico entre estas duas regiões pode gerar uma pilha, e, como consequência, a cinética da corrosão na zona anódica pode ser ainda maior.

\subsubsection{Caracterização metalográfica de soldas no aço carbono 1020}

Dos resultados anteriores, maiores alterações foram obtidas para a maior corrente de solda (100 A), devido à maior taxa de calor transferido ao metal. O aço carbono 1020 analisado foi a amostra com solda de 100 A. A amostra do aço 1020 foi atacada com solução de Nital 2,0\%, e as microestruturas foram observadas por microscopia óptica (Fig. 26) e MEV (Fig. 27). 


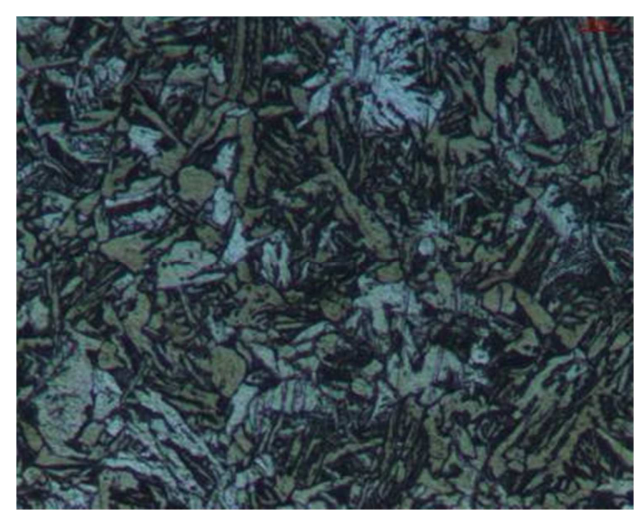

(a)

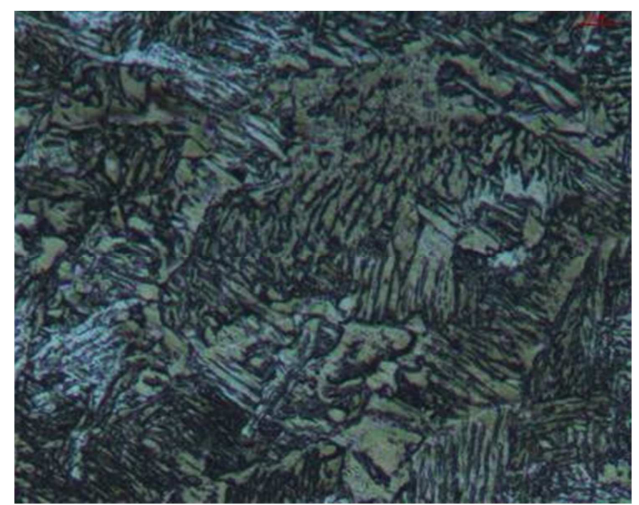

(c)

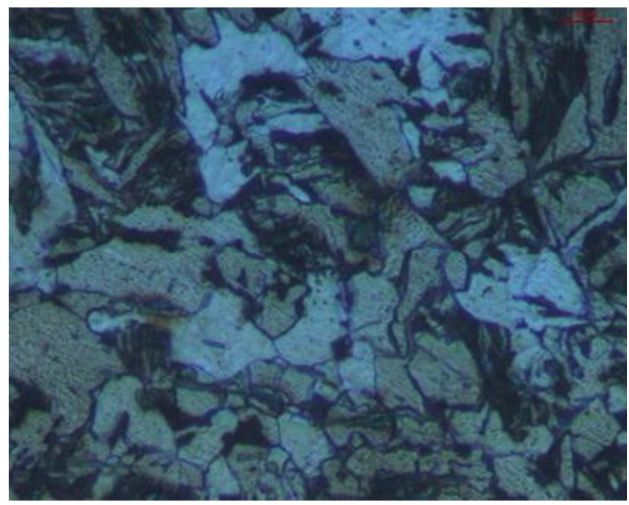

(b)

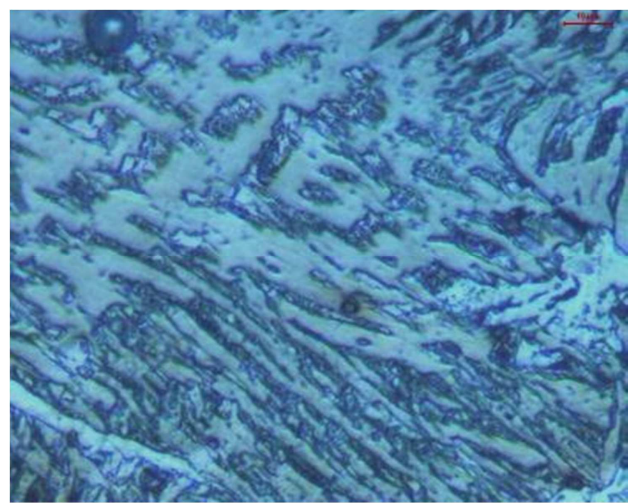

(d)

Figura 26 - Microestrutura do aço carbono 1020 com solda (corrente: 100 A), obtidas por MO, após ataque químico com solução de Nital 2,0\%. Regiões: (a) e (b) metal base; (c) e (d) solda.

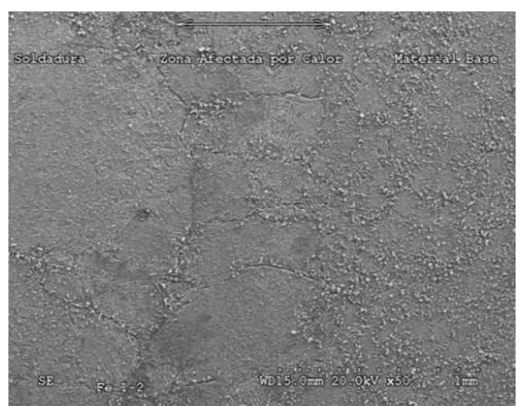

(a)

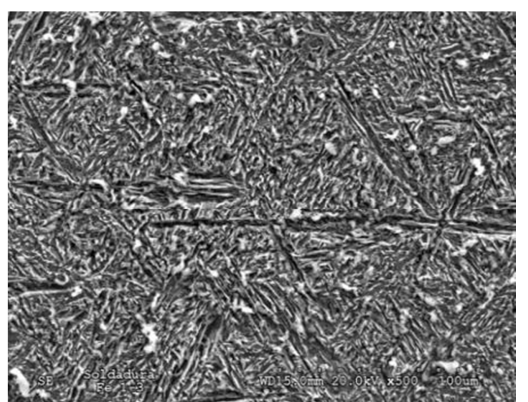

(b)

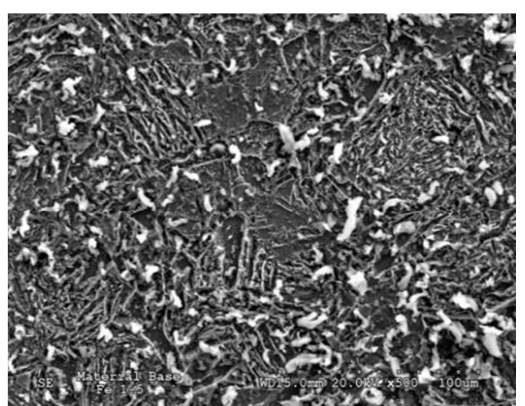

(c)

Figura 27 - Microestrutura do aço carbono 1020 com solda (corrente: 100 A), obtidas por MEV, após ataque químico com solução de Nital 2,0\%. Regiões: (a) e (b) metal base; (c) e (d) solda.

A estrutura inicial do aço carbono é do tipo ferrita e cementita; a análise das microscopias mostra uma alteração da microestrutura devido à fusão do material na região de solda, que se torna composta por perlita. O metal base apresenta uma estrutura com grãos mais bem definidos, com maiores diâmetros médios, e, em algumas regiões, se observa uma estrutura semelhante a "cacos de vidro quebrados". A região de solda apresenta uma estrutura mais alongada e compacta, com grãos menores que no metal base (perlita). Segundo autores essa alteração de morfologia não pode ser diretamente relacionada com a corrosão que o 
material apresenta. Uma diminuição no diâmetro médio dos grãos na região de solda também foi observado por Chaves et al. [95], examinando tubos de aço carbono. Estudando a corrosão destes tubos, os autores também concluíram que a diferença no tamanho de grãos não tem uma relação direta com a profundidade dos pites formados durante a corrosão do material.

As imagens do MEV (Fig. 27) complementam esta análise, pois possibilitam diferenciar a ZAC das demais regiões, o que pode ser visto por diferenças nas formas das microestruturas. A perlita é uma composição de duas fases, a $\alpha$-Fe (ferrita) e a cementita [9698]. Ela se caracteriza como uma microestrutura contendo grânulos denominados colônias, que são formadas por diversas camadas estreitas e finas orientadas em uma mesma direção (semelhante a lâminas); esta orientação das lâminas varia de uma colônia a outra. As camadas mais claras observadas nas imagens de microscopia óptica mostram a fase ferrita, e as camadas mais escuras são as fases cementita. A fase cementita, em geral, possui maior conteúdo de carbono que a fase ferrita [97]. Assim como foi feito para os aços inoxidáveis, análises de corrosão da solda do aço carbono serão apresentadas.

\subsubsection{Sensor pontual de corrosão: comparação com a célula convencional}

As regiões dos cordões de solda são muito estreitas em relação à área da célula convencional, inviabilizando a análise eletroquímica por este sistema. Uma possibilidade seria reduzir a área da célula convencional; entretanto, cordões de solda muito estreitos exigiriam áreas muito reduzidas, o que poderia resultar em outros problemas, como alta influência de efeitos de borda e, em potenciais de evolução de gases sobre o eletrodo, uma redução de área significativa devido, principalmente, à alta polarização por dessorção de oxigênio no ramo anódico. Desta maneira, outro sistema de medição de corrosão foi adotado, que não apresentasse tais problemáticas. Este sistema é o sensor pontual de corrosão (SPC), formado por uma mini-célula de corrosão. Além de redução da área de análise, estudos eletroquímicos de corrosão utilizando micro ou mini-células são interessantes por apresentar vantagens como menor gasto de reagente e amostra, dispensa a necessidade de cortar um pedaço da amostra de uma estrutura para análise e a portabilidade do dispositivo, permitindo medidas em campo.

Assim, nesta subseção é apresentado um estudo de comparação entre os dois sistemas de medidas eletroquímicas de corrosão, o SPC e a célula convencional. Para este estudo, foram feitas curvas de polarização potenciodinâmicas em $\mathrm{NaCl} 3,0 \%$, utilizando as amostras de aços inoxidáveis 304 e 316 sem solda (material base). As curvas de polarização 
potenciodinâmicas obtidas e os respectivos parâmetros eletroquímicos estão apresentados na figura 28 e na tabela 3 , respectivamente.

Os parâmetros eletroquímicos obtidos a partir das análises com a macrocélula são coerentes com valores reportados na literatura para os aços 304 e 316, [99,100]. Como é esperado, a presença do Mo no aço 316 o torna mais resistente contra a corrosão que o aço 304, o que foi refletido nos resultados pelo valor do $\mathrm{E}_{\text {corr }}$ mais positivo do aço 316 . As curvas de polarização feitas com o SPC apresentaram potenciais de corrosão próximos aos obtidos com a célula convencional, com diferenças de cerca de 20 a $50 \mathrm{mV}$ (para valores menores). É importante ressaltar que o SPC possui como eletrodo de referência, $\mathrm{Ag} / \mathrm{AgCl}$, enquanto que no sistema convencional foi utilizado um eletrodo de calomelanos saturado; além disso, conforme mencaionado na parte experimental, a célula convecnional e o SPC possuem diferentes geometrias das células e dos eletrodos, e contato entre a solução e o eletrodo de trabalho (no SPC há um material que intermedia este contato, enquanto que na célula convencional este contato é feito diretamente). Por estes motivos, os potenciais obtidos a partir do SPC nas análises foram convertidos para potenciais utilizando a célula convencional (o fator de conversão utilizado foi determinado experimentalmente). As curvas obtidas pelo SPC também mostram uma melhor definição com relação ao potencial de pite, uma vez que esta região apresenta-se melhor caracterizada que no outro sistema (o aumento de corrente é mais abrupto).

Os valores de potencial de pite obtidos pelo SPC também se mostraram superiores que na célula convencional. A maior diferença observada nos resultados obtidos pelos dois sistemas foi a densidade da corrente de corrosão, que apresentou diferença de cerca de uma ordem de grandeza com relação à célula convencional. O grau do ataque resultante nos dois casos foi observado por imagens de microscopia óptica, logo após os ensaios de polarização (Fig. 29). Pela imagens, é possível confirmar como o ataque resultante do SPC é mais intenso e localizado (o que pode justificar os maiores valores de densidade de corrente), enquanto que a célula convencional gera um ataque mais homogêneo, o que pode ser observado pela distribuição de pites ao longo da área analisada. Os valores de $\mathrm{R}_{\mathrm{p}}$ obtidos pelas análises com o SPC também foram maiores que na célula convencional, o que corrobora com os maiores valores de $\mathrm{E}_{\text {pite }}$ que também foram obtidos pelo SPC. 


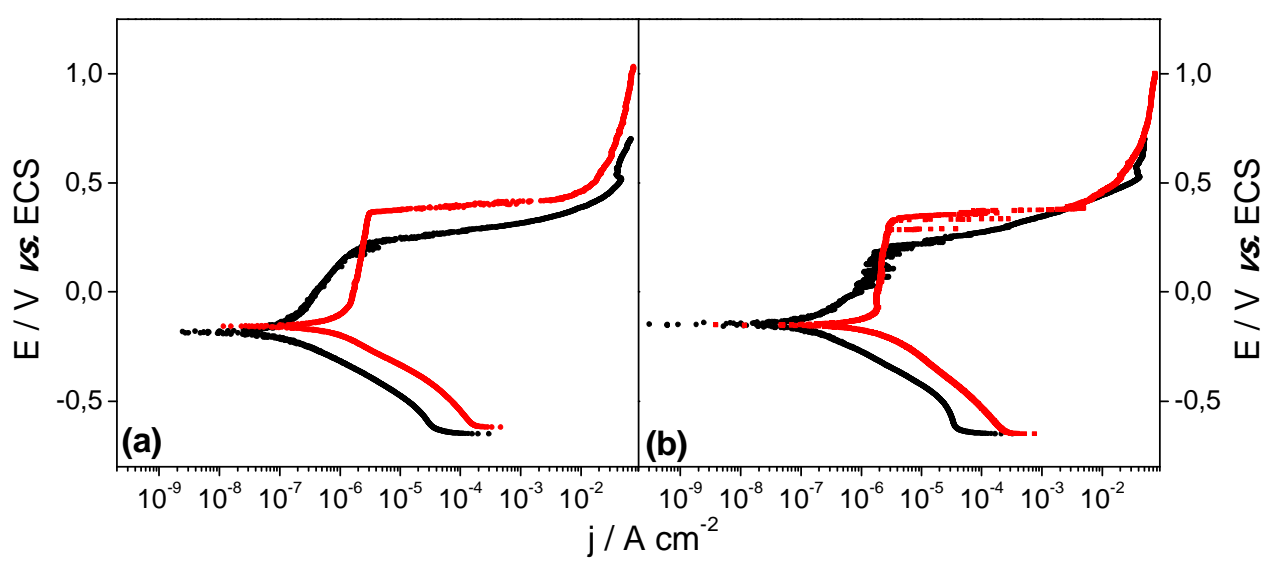

Figura 28 - Curvas de polarização potenciodinâmicas em solução de $\mathrm{NaCl}$ 3,0\% dos aços (a) 304 e (b) 316, utilizando a $\bullet$ célula convencional e o $\bullet$ SPC.

Tabela 3- Parâmetros eletroquímicos obtidos nas análises das curvas de polarização de aços 304 e 316 em solução de $\mathrm{NaCl}$ 3,0\% (Fig. 28), utilizando a célula convencional (CC) e o SPC

\begin{tabular}{|c|c|c|c|c|c|}
\hline & & $\mathrm{E}_{\text {corr }} / \mathrm{V} v \mathrm{vs.}$ ECS & $\mathbf{j}_{\mathrm{corr}} / \mu \mathrm{A} \mathbf{c m}^{-2}$ & $\mathbf{R}_{\mathrm{p}} / \mathbf{M} \boldsymbol{\Omega}$ & $\mathbf{E}_{\text {pite }} / \mathrm{V} v$ s. ECS \\
\hline \multirow{2}{*}{ Aço 304} & $\mathrm{CC}$ & $-0,146$ & 0,110 & 0,182 & 0,287 \\
\hline & SPC & $-0,205$ & 1,23 & 9,33 & 0,360 \\
\hline \multirow{2}{*}{ Aço 316} & $\mathrm{CC}$ & $-0,130$ & 0,172 & 0,091 & 0,328 \\
\hline & SPC & $-0,151$ & 1,74 & 18,8 & 0,371 \\
\hline
\end{tabular}

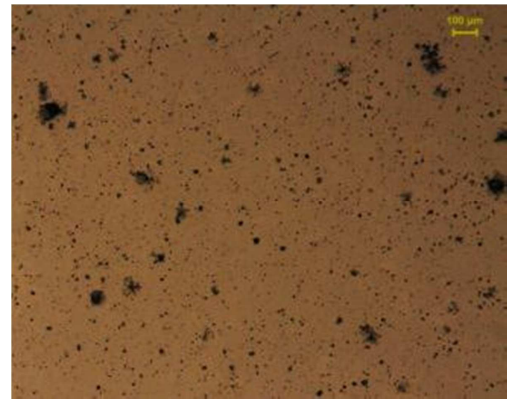

(a)

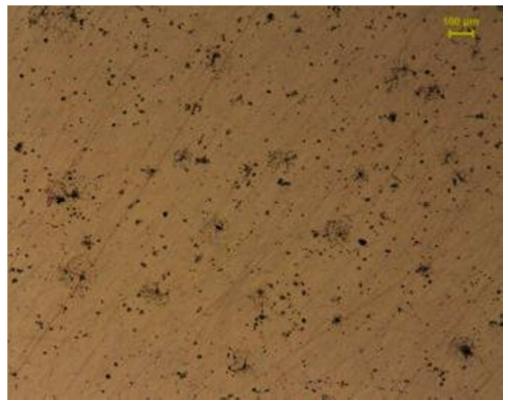

(c)

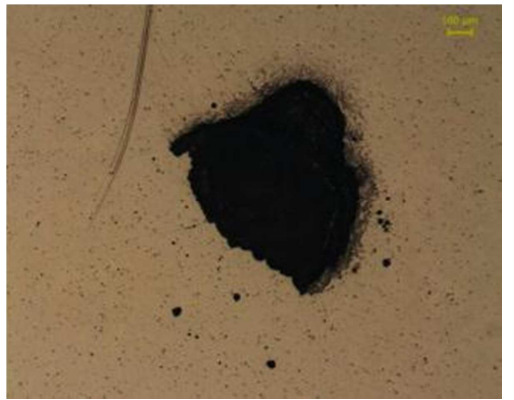

(b)

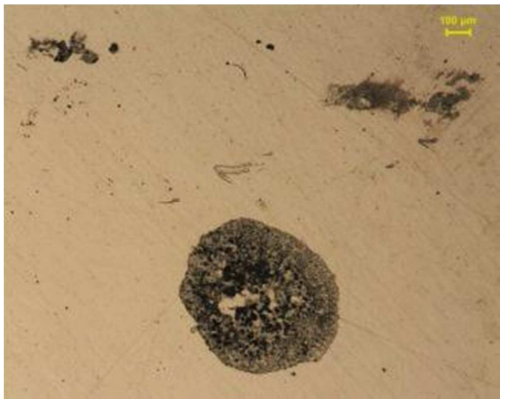

(d)

Figura 29 - Imagens de microscopia óptica após polarização potenciodinâmica em solução de $\mathrm{NaCl}$ 3,0\% dos aços: 304 na (a) cél. convencional e (b) SPC; e 316 na (c) cél. convencional e (d) SPC. 
Uma outra questão que foi cuidadosamente analisada é a determinação da área geométrica do SPC para normalização das correntes de corrosão. Uma vez que o sistema possui como contato com o eletrodo de trabalho uma ponta, a determinação desta área não é tão direta como no sistema convencional. Assim, esta área foi determinada observando-se com um microscópio a área atacada e, uma vez considerando-se esta como sendo aproximadamente circular, foi medido seu diâmetro médio. A partir deste valor, a área calculada resultou um valor de $0,00785 \mathrm{~cm}^{2}$; a área utilizada na célula convencional foi de $1,33 \mathrm{~cm}^{2}$. As diferenças nas correntes, em uma ordem de magnitude maiores no SPC, podem ser justificadas porque no SPC a análise é pontual, o que resulta em um ataque mais localizado e um campo mais concentrado em uma área menor, gerando densidades de correntes de corrosão maiores. Outro efeito que pode ser observado ao se utilizar o SPC é que, como uma área pequena está sendo analisada, os efeitos de heterogeneidades da liga podem ser mais críticos que no outro sistema. Na célula convencional estes efeitos de heterogeneidades são compensados por áreas maiores. Esta limitação inicial do SPC pode ser minimizada realizando-se várias medidas sobre a superfície e calculando-se uma média entre elas, de forma a diluir estas heterogeneidades.

Pelas análises comparativas utilizando aços inoxidáveis, pôde ser observado que o SPC, com relação à célula convencional, tem a tendência de apresentar valores de potenciais de corrosão menores, potenciais de pite maiores e uma significativa diferença nos valores de densidade de corrente de corrosão, de aproximadamente uma ordem de magnitude maior. Entretanto, o comportamento observado entre os dois aços analisados foi o mesmo utilizando tanto o SPC como a célula convecional; ou seja, o aço 316 apresentou, nos dois casos, maior resistência à corrosão (como era esperado). Desta forma, o comportamento dos dois aços com respeito à corrosão pôde ser observado de igual modo, sem prejuízos nas conclusões, utilizando os dois sistemas (ainda que eles apresentem algumas diferenças entre seus resultados).

Alguns trabalhos encontrados na literatura são interessantes para situar os resultados obtidos. Pereda et al. [101], dentre os objetivos de seu trabalho, compararam os resultados obtidos na análise da corrosão em soldas, utilizando uma macro e uma mini-célula. Comparando os dois sistemas, eles também obtiveram curvas de polarização com perfis muito semelhantes entre os dois diferentes tipos de células. Contudo, os autores observaram diferenças nos resultados, especialmente no caso da região de solda. Fatores como montagem experimental do sensor e viscosidade da solução são fatores que podem provocar variações nos resultados. Além disso, o material que está sendo analisado também influencia a análise. 
Outro ponto importante, é que utilizando a mini-célula não é possível obter de forma direta e precisa a área de análise, como no caso da célula convencional. Assim, as variações nas correntes de corrosão entre um sistema miniaturizado e um sistema convencional podem estar associados a estes fatores. Outro fator que foi citado por Pereda et al. [101] sobre diferenças na corrente de corrisão entre dois sitemas diferentes é que, em regiões que sofreram alterações química ou estrutural, como regiões de solda, existe a possibilidade de ocorrer uma corrosão interdendrítica na região modificada; como consequência, uma maior rugosidade do metal seria observada, o que poderia resultar em uma maior área superficial e, consequentemente, um densidade de corrente errônea, já que a área ativa não poderia ser determinada por uma simples análise geométrica.

Contudo, neste estudo foi observado que o SPC apresentou resultados reprodutíveis para os aços inoxidáveis, e desta forma, pode-se concluir que este dispositivo pode ser utilizado para medidas de corrosão, sem prejuízos em indicar o comportamento comparativo de cada sistema analisado.

Contudo, neste estudo foi observado que o SPC apresentou resultados reprodutíveis para os aços inoxidáveis, e desta forma, pode-se concluir que este dispositivo pode ser utilizado para medidas de corrosão, sem prejuízos em indicar o comportamento comparativo de cada sistema analisado.

\subsubsection{Influência da corrente de solda na corrosão de aços inoxidáveis}

Para o estudo da corrosão nas soldas feitas em aços inoxidáveis, utilizou-se o SPC, pois como foi comprovado anteriormente os resultados comparativos são muito similares entre este dispositivo e o uso da célula convencional. O estudo foi feito para as diferentes correntes de solda $(15,35,70$ e 100 A). As curvas de polarizacao resultantes e os respectivos parâmetros eletroquímicos estão apresentados na Figura 30 e na tabela 4 para o aço 304, e na Figura 31 e na tabela 5 para o aço 316. 


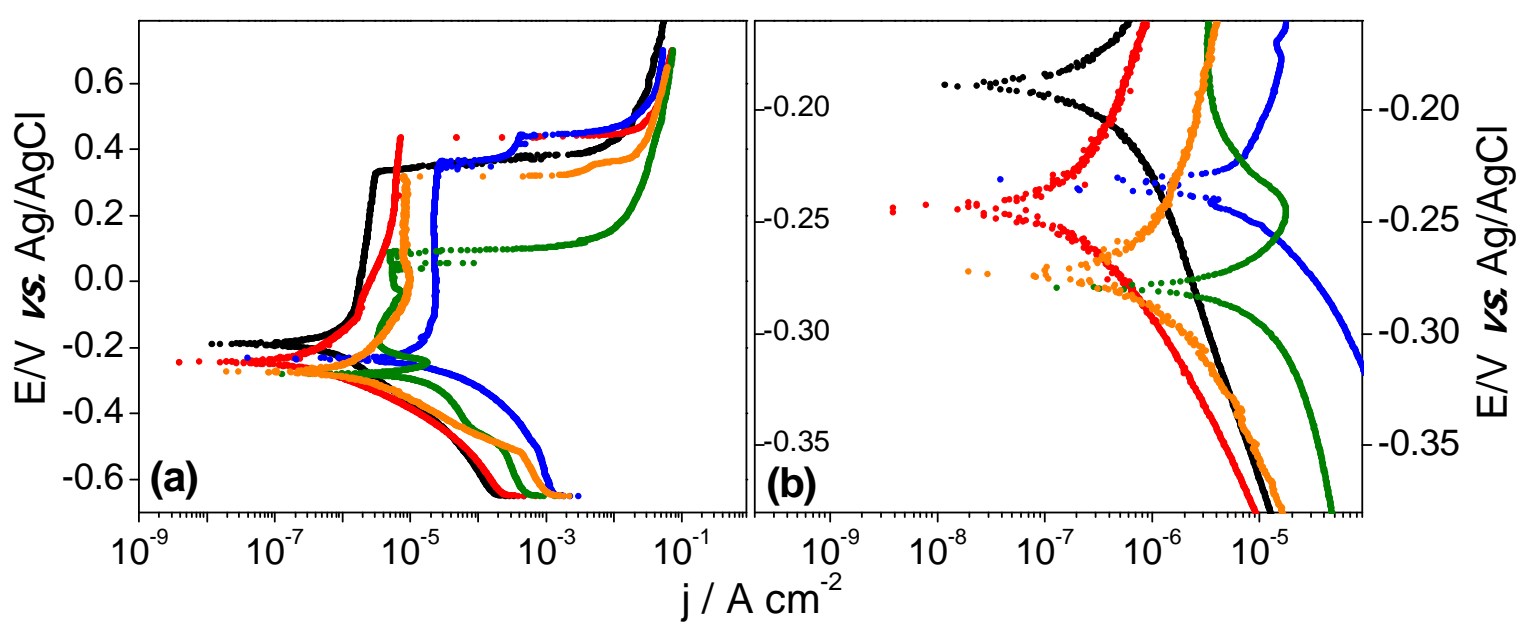

Figura 30 - Curvas de polarização potenciodinâmica (utilizando o SPC) em solução de NaCl 3,0\% do aço 304: • material base; e com soldas de: • 15, • 35, 70 e $\bullet 100$ A. (a) Curvas de polarização completas e (b) ampliação da região dos potenciais de corrosão.

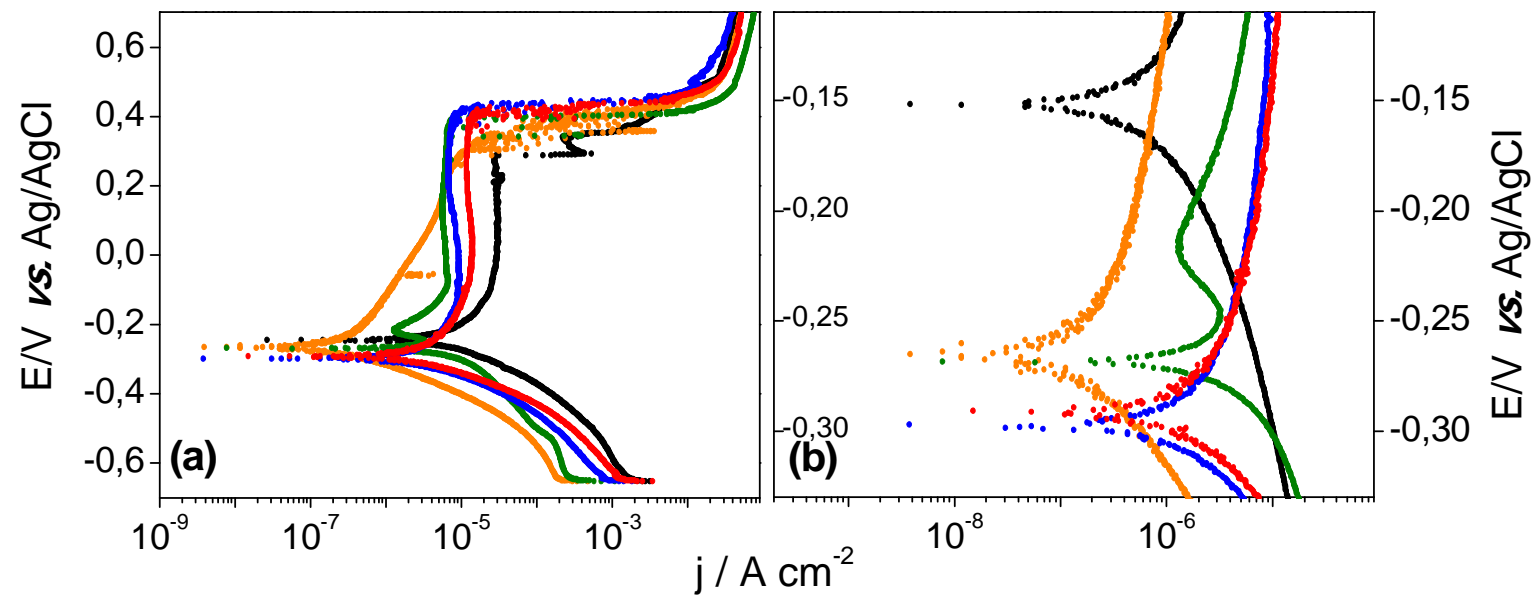

Figura 31 - Curvas de polarização potenciodinâmica (utilizando o SPC) em solução de NaCl 3,0\% do aço 316: • material base; e com soldas de: • 15, • 35, 70 e $\bullet 100$ A. (a) Curvas de polarização completas e (b) ampliação da região dos potenciais de corrosão.

De modo geral, observa-se que as regiões com solda apresentaram menores valores de Ecorr e maiores jcorr. As Rpol mantiveram-se aproximadamente constantes ou diminuíram nas regiões de solda; os valores de Epite, contudo, apresentaram valores maiores que o metal base. A diminuição do Ecorr com o aumento da corrente de solda provavelmente se deve à maior porcentagem de fase ferrita; pelas microestruturas analisadas no início do capítulo (Figs. 23 a 25 - análise microestrutural), observou-se que a maiores correntes de solda, a fase 
Tabela 4 - Parâmetros eletroquímicos obtidos nas análises das curvas de polarização do aço 304 com diferentes correntes de solda (Fig. 30)

\begin{tabular}{|ccccc|}
\hline Amostra & $\mathbf{E}_{\text {corr }} / \mathbf{V} \boldsymbol{v s .} \mathbf{A g} / \mathbf{A g C l}$ & $\mathbf{j}_{\text {corr }} / \mu \mathbf{A ~ c m}{ }^{-2}$ & $\mathbf{R}_{\text {pol }} / \mathbf{M} \boldsymbol{\Omega}$ & $\mathbf{E}_{\text {pite }} / \mathbf{V} \boldsymbol{v s .} \mathbf{A g} / \mathbf{A g C l}$ \\
\hline Material base & $-0,236$ & 1,23 & 9,33 & 0,329 \\
Solda 15 A & $-0,277$ & 1,67 & 1,10 & 0,313 \\
Solda 35 A & $-0,231$ & 7,94 & 1,99 & 0,092 \\
\hline Solda 70 A & $-0,223$ & 23,3 & 5,82 & 0,445 \\
\hline Solda 100 A & $-0,245$ & 6,02 & 1,36 & 0,428 \\
\hline
\end{tabular}

Tabela 5 - Parâmetros eletroquímicos obtidos nas análises das curvas de polarização do aço 316 com diferentes correntes de solda (Fig 31)

\begin{tabular}{|ccccc|}
\hline Amostra & $\mathbf{E}_{\text {corr }} / \mathbf{V} \boldsymbol{v s .} \mathbf{A g} / \mathbf{A g C l}$ & $\mathbf{j}_{\text {corr }} / \boldsymbol{\mu A} \mathbf{~ c m}^{-2}$ & $\mathbf{R}_{\text {pol }} / \mathbf{M} \boldsymbol{\Omega}$ & $\mathbf{E}_{\text {pite }} / \mathbf{V} \boldsymbol{v s .} \mathbf{A g} / \mathbf{A g C l}$ \\
\hline Material base & $-0,182$ & 1,74 & 18,8 & 0,340 \\
Solda 15 A & $-0,265$ & 0,340 & 4,77 & 0,400 \\
Solda 35 A & $-0,218$ & 6,48 & 14,1 & 0,395 \\
Solda 70 A & $-0,316$ & 12,6 & 1,49 & 0,426 \\
Solda 100 A & $-0,339$ & 16,0 & 2,04 & 0,420 \\
\hline
\end{tabular}

ferrítica é vista com mais nitidez; assim, conclui-se que maiores temperaturas estão estabilizando melhor esta fase. Com relação à fase austenítica, a fase ferrítica apresenta menor valor de Ecorr; assim, o aumento da proporção desta fase (o que ocorre com o aumento da corrente) desloca o Ecorr para valores mais negativos.

Para dar sustentação à justificativa mencionada, as diferentes soldas dos aços $304 \mathrm{e}$ 316 foram utilizadas para fazer uma análise de polarização potenciodinâmica em solução de cloreto, utilizando a célula convencional. Embora este sistema não seja o mais recomendado para este tipo de análise, conforme já discutido anteriormente, o objetivo destes experimentos foi unicamente provocar um ataque de corrosão nas amostras para serem posteriormente analisados por microscopia óptica. Uma vez formados os pites na superficie, as imagens destas amostras foram apresentadas na figura 32; os resultados eletroquímicos foram desconsiderados nesta análise. Observa-se, a partir da análise destas microscopias, que a corrosão provocada nas regiões de solda não são tão intensas como a corrosão provocada no 


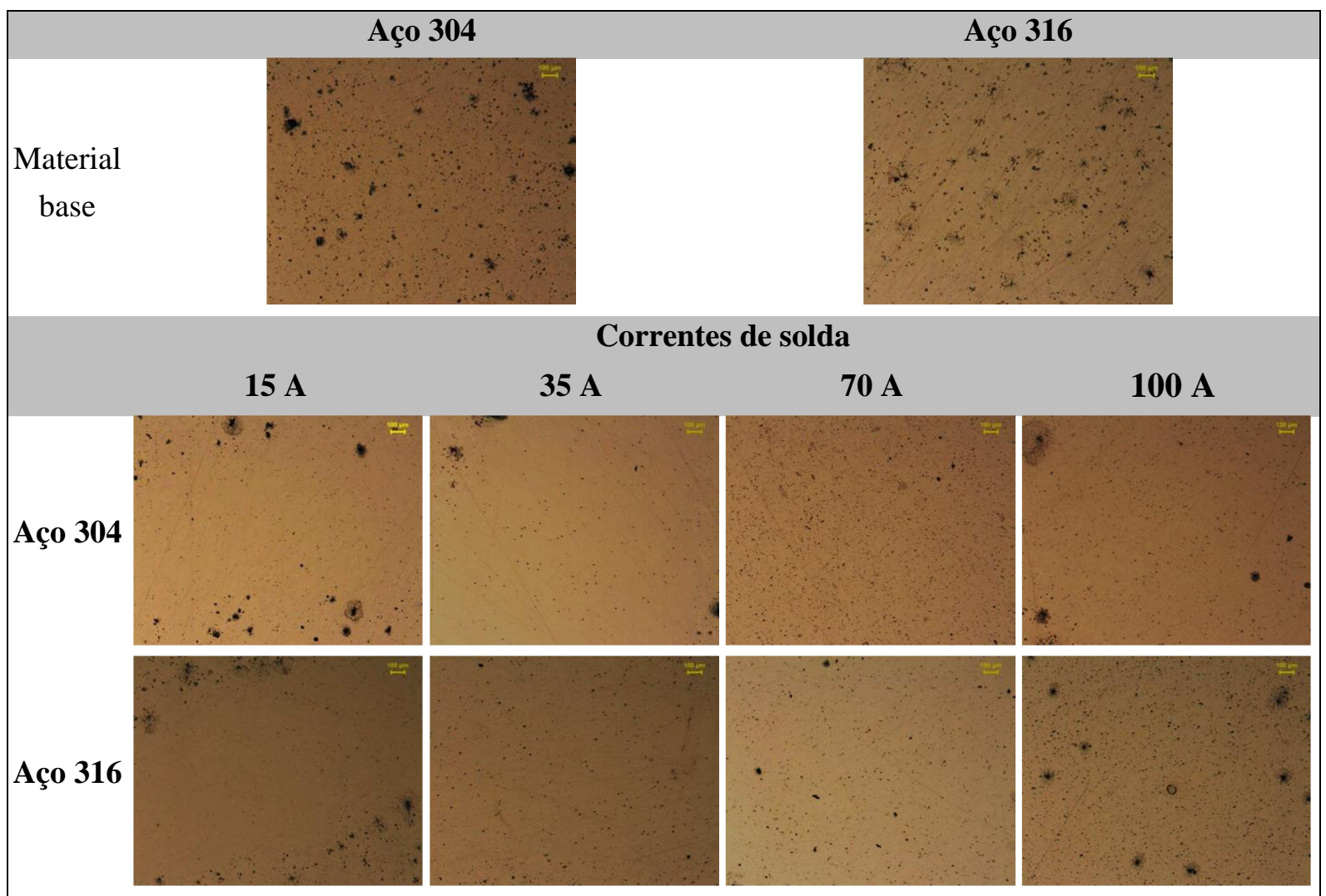

Figura 32 - Imagens de microscopia óptica dos aços 304 e 316 com diferentes soldas após ensaio de polarização potenciodinâmica (utilizando a célula convencional) em solução da $\mathrm{NaCl} 3,0 \%$.

metal base (em todas correntes de solda utilizadas); a região do metal base apresenta pontos de corrosão mais intensos. Observa-se que a região de solda apresenta corrosão caracterizada apenas por pequenos pites homogeneamente distribuídos, enquanto que o metal base apresenta dois tipos de ataque de corrosão: pequenos pites e uma corrosão sobre uma área maior, com um aspecto semelhante a "favos de mel". Pereda et al. [101], utilizando uma célula convencional em suas análises, também descreveram este tipo de ataque, os quais foram observados nas regiões do metal base e da ZAC.

Para tentar correlacionar a influência da corrosão com a estrutura cristalina, um ataque químico foi feito nas amostras de aço 304 e 316 com solda de 70 A após o ensaio de polarização potenciodinâmica (Fig. 33). De fato, se observa que a estrutura ferrítica (região de solda) promoveu uma corrosão mais homogeneamente distribuída, enquanto que a estrutra austenítica (região do metal base) favoreceu a formação de pontos de ataques mais intensos ("favos de mel"). 


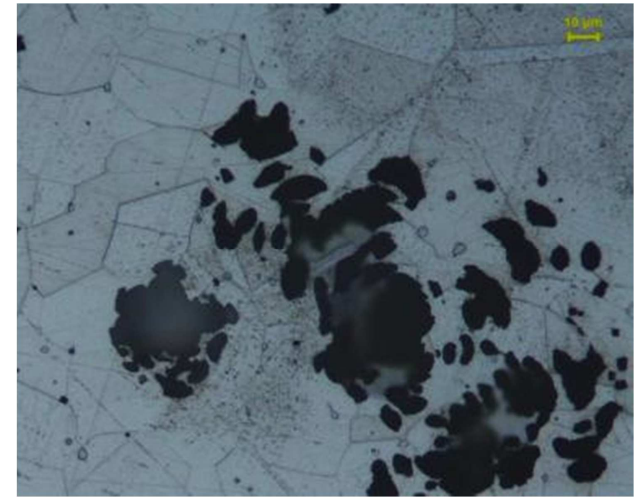

(a)

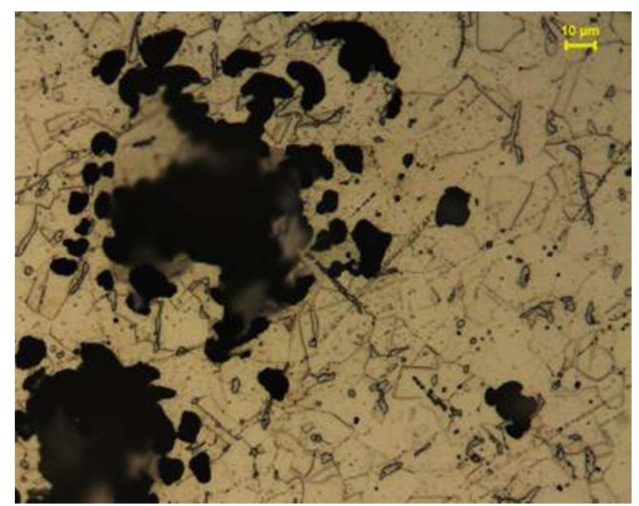

(c)

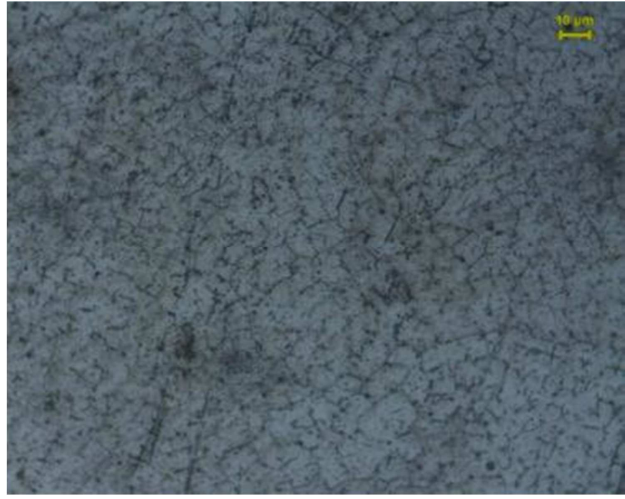

(b)

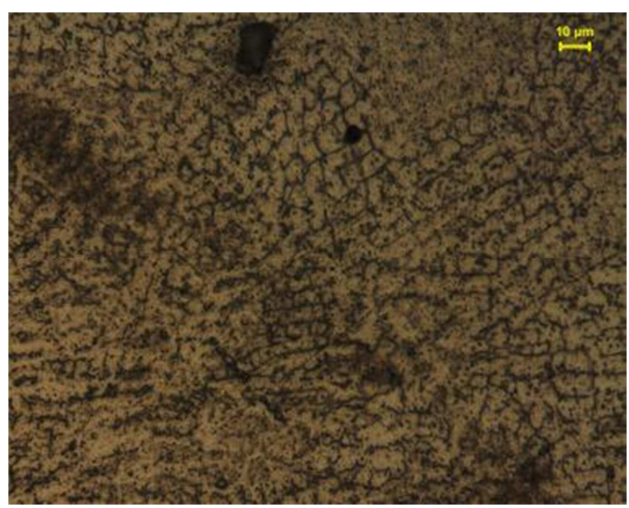

(d)

Figura 33 - Imagens de microscopia óptica de aços com solda de 70 A após ensaio de polarização potenciodiâmica (utilizando a célula convencional) em solução de $\mathrm{NaCl}$ 3,0\%. Aço 304: (a) metal base e (b) solda; aço 316: (c) metal base e (d) solda (ampliação: 500x).

Estes resultados mostram que a mudança na estrutura cristalina na região de solda foi benéfica para proteção contra a corrosão, pois esta sofreu menor grau de ataque que o metal base. Desta forma, a região de solda não é a mais susceptível à corrosão. Os valores de $\mathrm{E}_{\text {pite }}$ obtidos na análise eletroquímica (Tab. 4 e 5) são, em geral, maiores para as regiões de solda; ainda, maiores correntes de solda resultaram em maiores valores de $\mathrm{E}_{\text {pite, }}$ o que mostra que a corrosão menos intensa na região de solda muito provavelmente está ligada à mudança de sua microestrutura.

Pereda et al. [101] também utilizaram uma mini-célula de corrosão para estudar a formação de pites em soldas feitas em aço super martensítico, em meio de cloreto. Os autores também observaram que a região de solda apresentou valores mais nobres de $\mathrm{E}_{\text {pite }}$, assim como observado nos resultados obtidos para os aços 304 e 316. Entretanto, eles utilizaram um material de enchimento diferente do metal base; isto pode também estar associado aos valores de $E_{\text {pite }}$ superiores na região da solda. Neste trabalho, entretanto, os resultados refletem somente a mudança de cristalinidade do metal, sem alteração química. Ainda segundo os 
autores, a região de solda apresentou maior capacidade de repassivação que as outras regiões analisadas. Assim, os menores valores de $\mathrm{E}_{\text {corr }}$ (mais negativos que o metal base) observados nos resultados apresentados podem estar relacionados com uma maior capacidade de repassivação da região de solda: a oxidação inicial do aço diminui o potencial, gerando a camada de óxido de passivação. Ou seja, ocorre uma corrosão inicial do metal para formar, posteriormente, um filme de óxido aderente e protetor.

Desta forma, pode-se concluir que os resultados eletroquímicos obtidos são coerentes com os resultados de microscopia, pois demonstra que a região de solda é menos susceptível à corrosão que o metal base. Deste conjunto de resultados permite afirmar que a formação da fase ferrítica está aumentando a resistência da região de solda contra a corrosão, e esta proteção torna-se mais pronunciada conforme a corrente de solda aumenta.

Outra hipótese que foi estudada, e que poderia ocorrer na zona de solda e influenciar os resultados observados, é a micro segregação de elementos químicos. Para isto, foi utilizada a técnica de EDX para verificar a composição química entre as regiões de solda e metal base nos aços inoxidáveis (Fig. 34). A análise das porcentagens de composição dos elementos (tabela 6) para os aços 304 e 316, mostra, contudo, que não houve alteração significativa da composição química média entre as regiões de solda e metal base. Uma análise mais pontual (ainda por EDX) foi feita na região de solda para, de fato, excluir a possibilidade de estar havendo micro segregação de elementos químicos nesta região (Fig. 35). Duas estruturas da região de solda foram analisadas: uma estria (marcada como "1" na Fig. 35a) e uma zona lisa (marcada como número "2" na mesma imagem). São observadas algumas diferenças, principalmente na quantidade de Ni e S (Tabela 7). Entretanto, não se observa diferenças na quantidade de $\mathrm{Cr}$, que poderia haver precipitado na forma de carbetos. 


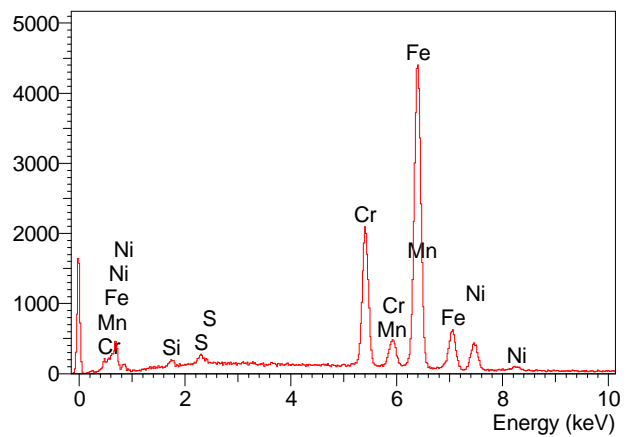

(a)

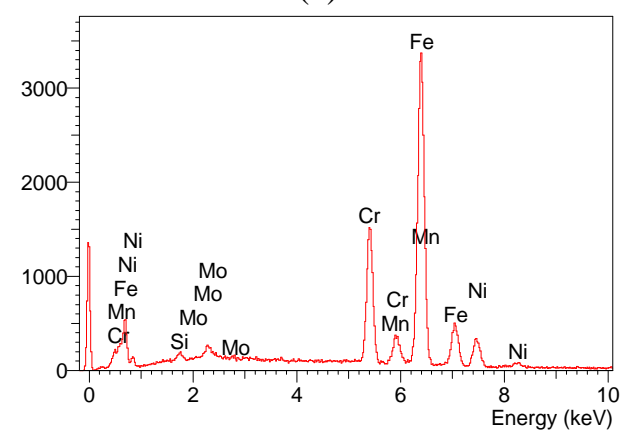

(c)

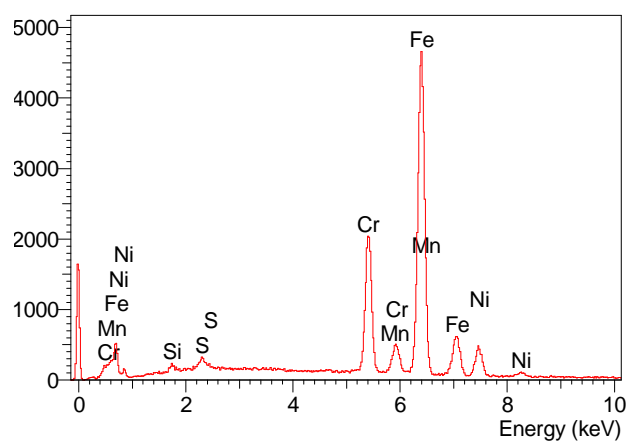

(b)

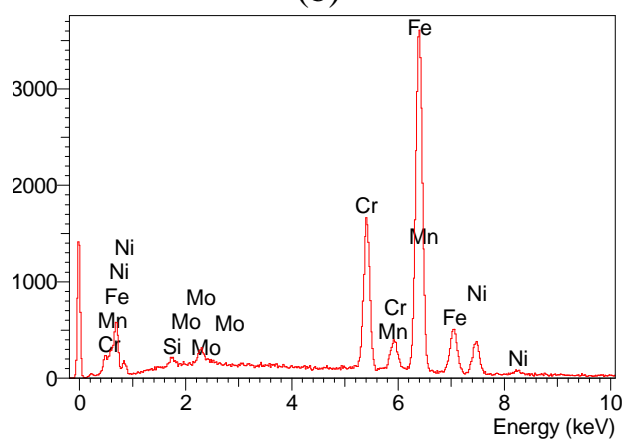

(d)

Figura 34 - Análise de EDX nas regiões de solda dos aços 304 e 316 com solda de 100 A. Aço 304: (a) solda e (b) metal base; aço 316: (c) solda e (d) metal base (Magnificação da foto de MEV: 500x).

Tabela 6 - Análise de EDX (Fig. 34) das composições químicas do metal base e da região de solda (corrente de 100 A) dos aços 304 e 316

\begin{tabular}{|cccccccccc|}
\cline { 3 - 10 } & & \multicolumn{7}{c|}{ \% Elemento } \\
& & Si & Cr & Mn & Fe & Ni & S & Mo \\
\hline \multirow{2}{*}{ Aço 304 } & Solda & 0,53 & 18,90 & 2,23 & 68,22 & 9,58 & 0,55 & -- \\
& Metal base & 0,53 & 18,44 & 2,38 & 68,19 & 9,90 & 0,56 & -- \\
\hline \multirow{2}{*}{ Aço 316 } & Solda & 0,58 & 18,44 & 2,21 & 67,05 & 9,79 & -- & 1,93 \\
& Metal base & 0,58 & 18,27 & 1,85 & 67,02 & 10,12 & -- & 2,16 \\
\hline
\end{tabular}

Portanto, por esta análise pode-se concluir que, além de não haver alteração na composição química entre as regiões de solda e metal base, também não há diferenças significativas entre as composições das estrias e das regiões lisas, na zona de solda, a não ser pela quantidade de Ni e S. Este resultado é desejável para evitar a corrosão, pois, em geral, a segregação de elementos aumenta a corrosão pela formação de ilhas com diferentes potenciais termodinâmicos. Dadfar et al. [92] explicaram que o resfriamento de soldas TIG (utilizando 


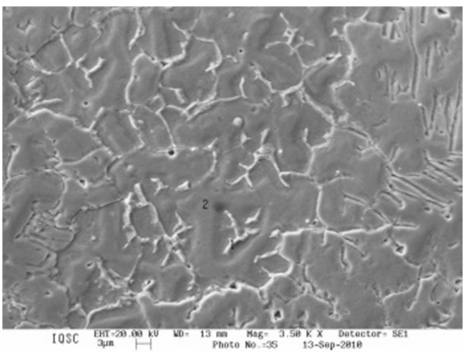

(a)

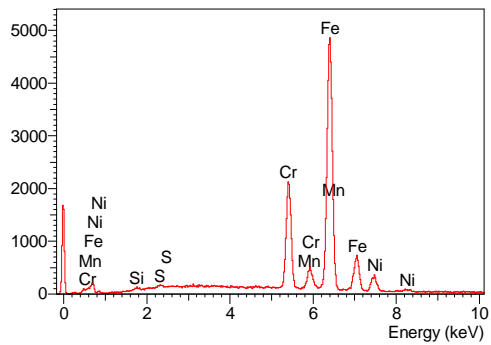

(b)

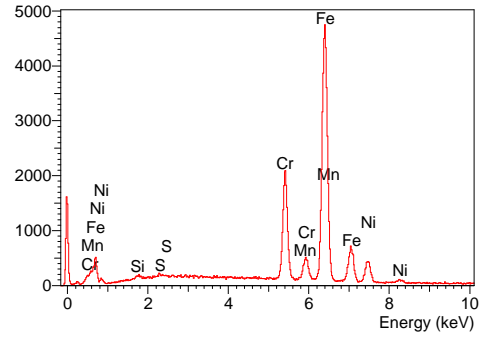

(c)

Figura 35 - Análise da composição química por EDX da região de solda (100 A) em aço 304. (a) Imagem de MEV mostrando as estruturas analisadas ("1" e "2"). Espectros de EDX das estruturas de (b) estria (região "1") e (c) lisa (região "2").

aço 316L) é rápido na zona de fusão, o que impede cineticamente a micro segregação dos elementos. A região onde é provável que ocorra micro segregação é a região vizinha à solda, ZAC. Assim, nos aços estudados, é pouco provável que tenha ocorrido a micro segregação na zona de fusão, pois ela colaboraria para aumento da corrosão. Os autores também observaram maior corrosão na região do metal base do que na solda para caso do aço 316L.

Após as análises de polarização potenciodinâmica, a morfologia dos ataques provocadas pelas análises utilizando o SPC foi observada por microscopia óptica (Fig. 36). Estas análises provocaram ataques intensos, com uma morfologia diferente da provocada quando usando a célula convencional. Pode-se observar a partir das microscopias que o ataque, por ser muito intenso e localizado, não gera diferenças significativas na corrosão entre a zona de solda e o metal base.

Se observam vários "buracos" decorrentes da corrosão (Fig. 36), porém todos semelhantes entre si e com alto grau de intensidade no ataque. Garcia et al. [75], utilizando uma minicélula para estudar a corrosão em soldas (MIG) dos aços 304 e 316L (usando aço 308 como metal de enchimento) observaram ataques intensos sobre o metal após os ensaios eletroquímicos de polarização, e chamaram de "buracos" os ataques provocados pelo dispositivo. Os resultados experimentais aqui obtidos mostram uma corrosão semelhante à descrita por estes autores, os quais também relataram que a alteração da composição química na zona de fusão (pela adição de metal de enchimento) provoca maior corrosão desta região. Contudo, a melhora ou piora da corrosão na zona de fusão dependerá da composição química do metal de enchimento utilizado, com relação à composição química do metal base. Os autores também descrevem que, para as amostras que receberam tratamento térmico após a soldagem, ZAC apresentou alta suscetibilidade à corrosão. 


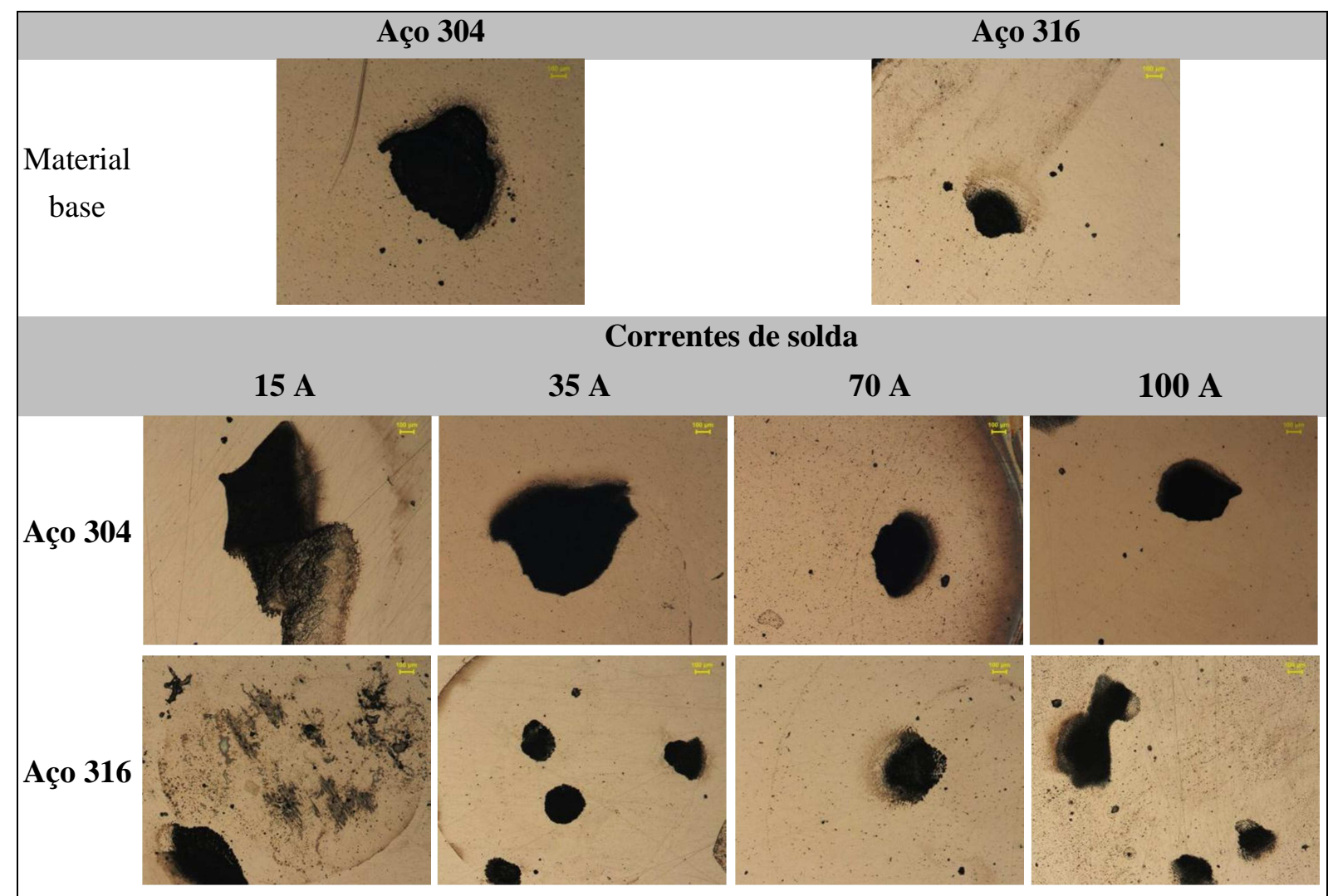

Figura 36 - Microscopia óptica dos aços 304 e 316 com diferentes soldas após ensaio de polarização potenciodinâmica (utilizando o SPC) em solução da $\mathrm{NaCl} 3,0 \%$.

Tabela 7 - Análise de EDX (Fig. 35) das composições químicas das diferentes estruturas na região de solda (100 A) do aço 304

\begin{tabular}{|lcccccc|}
\cline { 2 - 7 } \multicolumn{1}{c|}{} & \multicolumn{5}{c}{ Elemento / \% } \\
\cline { 2 - 7 } & $\mathbf{S i}$ & $\mathbf{C r}$ & $\mathbf{M n}$ & $\mathbf{F e}$ & $\mathbf{N i}$ & $\mathbf{S}$ \\
\hline Estria (região 1) & 0,23 & 18,65 & 1,92 & 72,10 & 6,89 & 0,21 \\
\hline Lisa (região 2) & 0,31 & 18,38 & 2,20 & 69,60 & 9,38 & 0,14 \\
\hline
\end{tabular}

Uma característica observada com relação às diferentes correntes de soldagem é que a amostra com solda de 15 A resultou em baixa penetração da solda; um desgaste da superfície soldada logo revelava que as partes do metal não estavam unidas pela solda. Por isso, soldas com esta corrente não foram utilizadas nas seções subsequentes. De modo geral, a corrosão em metais devido aos processos de soldagem pode ser diminuída, desde que condições especiais de soldagem sejam utilizadas, como o uso de óxidos inorgânicos junto ao gás de blindagem [102]; entretanto, este procedimento extrapola os objetivos do presente trabalho. 

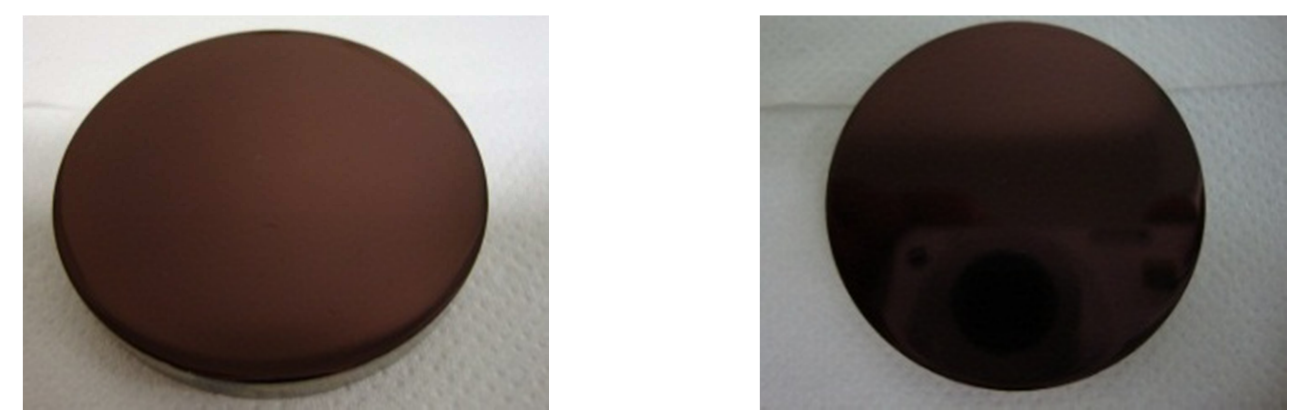

Figura 37 - Aço 316 com solda de 100 A recoberto com PAni.
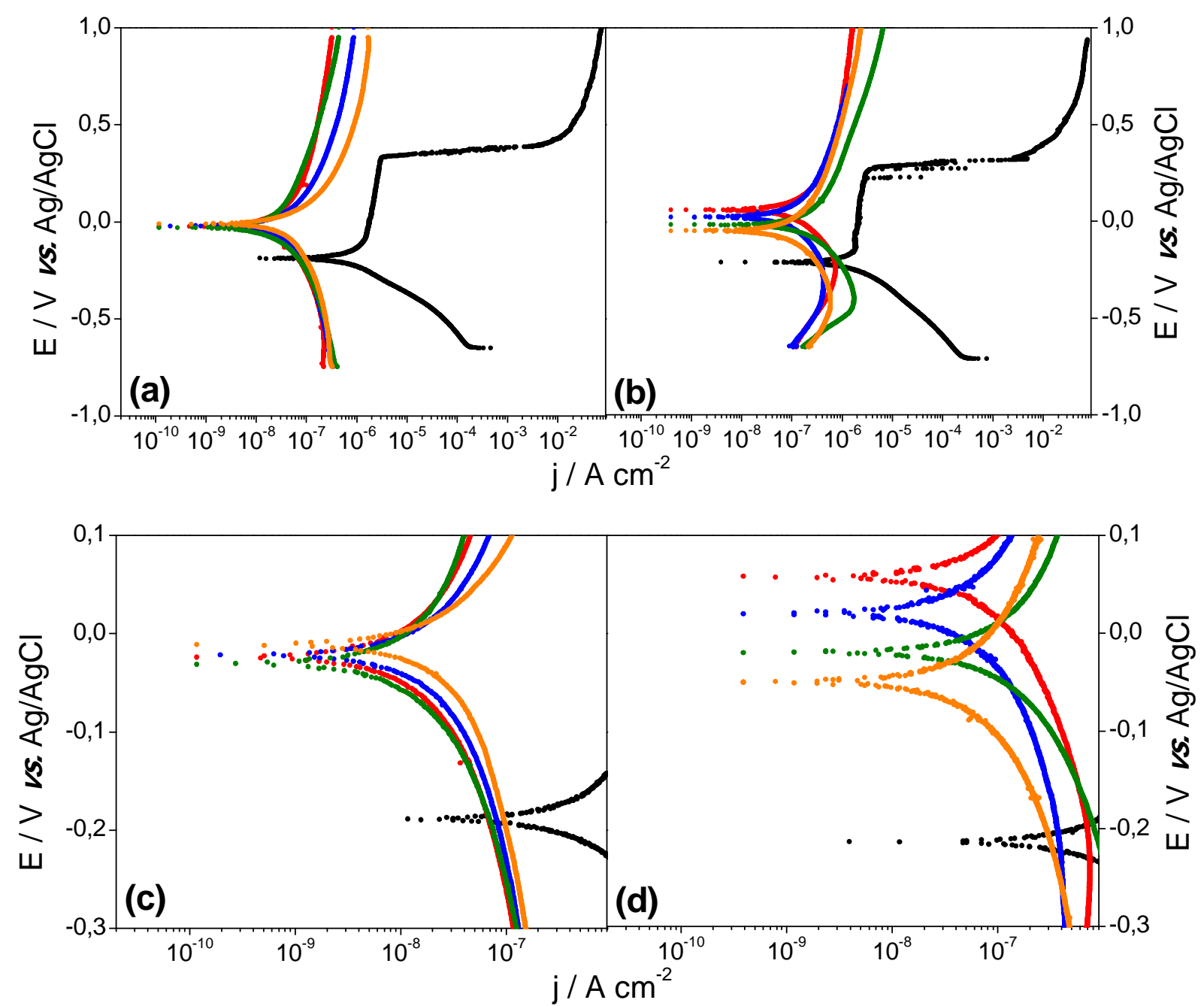

Figura 38 - Curvas de polarização potenciodinâmica (utilizando o SPC) em solução de $\mathrm{NaCl}$ 3,0\% dos aços: 304 - (a) curvas completas e (c) ampliação da região dos potenciais de corrosão; 316 - (b) curvas completas e (d) ampliação da região dos $\mathrm{E}_{\text {corr }} \bullet$ Material base sem recobrimento; • material base com PAni; regiões de solda com PAni: • 35, $\bullet 70$ e $\bullet 100$ A.

\subsubsection{Aplicação de revestimento protetor de PAni para proteção contra a corrosão de} soldas dos aços 304 e 316

Aços inoxidáveis expostos a ambientes agressivos, como soluções de cloreto, estão sujeitos à corrosão, principalmente à corrosão localizada (por pites) e por isso, é importante a 
Tabela 8 - Parâmetros eletroquímicos obtidos nas análises das curvas de polarização de soldas do aço 304 recobertos com PAni (Fig. 38a)

\begin{tabular}{|c|c|c|c|c|c|}
\hline \multicolumn{2}{|c|}{ Amostra } & $\mathrm{E}_{\text {corr }} / \mathrm{V} v$ v. $\mathrm{Ag} / \mathrm{AgCl}$ & $\mathrm{j}_{\text {corr }} / \mathrm{nA} \mathrm{cm}^{-2}$ & $\mathbf{R}_{\mathrm{pol}} / \mathbf{M} \boldsymbol{\Omega}$ & $\mathbf{E}_{\text {pite }} / \mathbf{V}$ vs. Ag/AgCl \\
\hline \multicolumn{2}{|c|}{ Material base sem PAni } & $-0,205$ & 1.100 & 9,33 & 0,360 \\
\hline \multirow{4}{*}{ Com PAni } & Material base & $-0,033$ & 14,1 & 230 & -- \\
\hline & Solda $35 \mathrm{~A}$ & $-0,035$ & 16,9 & 146 & -- \\
\hline & Solda $70 \mathrm{~A}$ & $-0,024$ & 14,3 & 255 & -- \\
\hline & Solda $100 \mathrm{~A}$ & $-0,022$ & 29,0 & 130 & -- \\
\hline
\end{tabular}

Tabela 9 - Parâmetros eletroquímicos obtidos nas análises das curvas de polarização de soldas do aço 316 recobertos com PAni (Fig. 38b)

\begin{tabular}{|c|c|c|c|c|c|}
\hline \multicolumn{2}{|c|}{ Amostra } & $\mathrm{E}_{\text {corr }} / \mathrm{V} v s . \mathrm{Ag} / \mathrm{AgCl}$ & $\mathbf{j}_{\mathrm{corr}} / \mathbf{n A ~ \text { cm} ^ { - 2 }}$ & $\mathbf{R}_{\mathrm{pol}} / \mathrm{M} \Omega$ & $\overline{\mathrm{E}_{\text {pite }} / \mathrm{V} v s . \mathrm{Ag} / \mathrm{AgCl}}$ \\
\hline \multicolumn{2}{|c|}{ Material base sem PAni } & $-0,151$ & 1.740 & 18,8 & 0,371 \\
\hline \multirow{4}{*}{ Com PAni } & Material base & 0,058 & 70,4 & 31,4 & -- \\
\hline & Solda $35 \mathrm{~A}$ & 0,016 & 46,3 & 37,9 & -- \\
\hline & Solda $70 \mathrm{~A}$ & $-0,016$ & 93,3 & 17,3 & -- \\
\hline & Solda 100 A & $-0,053$ & 48,9 & 38,8 & -- \\
\hline
\end{tabular}

utilização revestimentos protetores contra a corrosão. Nesta parte, revestimentos a base de PAni foram utilizados para proteger as ligas e suas soldas contra a corrosão por pites em ambientes contendo cloreto.

A temperatura de síntese do polímero foi mantida constante a $0{ }^{\circ} \mathrm{C}$, e este foi utilizado na forma desdopada, conforme procedimento já descrito na parte experimental. Às superfícies do aço foram adicionadas a solução de NMP com PAni, e esta foi seca em estufa à vácuo por 12 h, à $60^{\circ} \mathrm{C}$. Todas as amostras de aços 304 e 316 apresentaram o mesmo aspecto, o de um filme de polímero com alta homogeneidade, como apresentado pela figura 37 (aço $316 \mathrm{com}$ solda de 100 A); não é possível distinguir nas amostras as regiões de solda e do metal base.

Os aços 304 e 316 com diferentes soldas, e recobertos com PAni, foram utilizados para fazer ensaios eletroquímicos de polarização potenciodinâmica, utilizando o SPC como célula eletroquímica. As análises nas soldas resultaram nas curvas de polarização apresentadas na figura 38; os parâmetros eletroquímicos estão apresentados nas tabelas 8 (aço 
304) e 9 (aço 316). O potencial de corrosão apresentado pelos aços com PAni foi de aproximadamente $0 \mathrm{~V}$; assim, o revestimento proporcionou um deslocamento positivo de cerca de $170 \mathrm{mV}$ no potencial de corrosão dos aços 304, e cerca de $100 \mathrm{mV}$ nos aços 316. As correntes de corrosão apresentaram uma redução de duas ordens de magnitude, em média. Adicionalmente, as amostras com recobrimento não apresentaram potencial de pite no intervalo de potenciais estudado. Já a resistência de polarização apresentou maiores valores para a os aços 304, em cerca de uma ordem de magnitude. Tanto metal base como solda foram eficientemente protegidas com o revestimento polimérico.

No aço 304, os parâmetros eletroquímicos para a amostra sem solda e com corrente de solda de $35 \mathrm{~A}$ apresentaram valores de $\mathrm{E}_{\text {corr }}$ muito próximos. Este valor aumentou levemente, em cerca de $10 \mathrm{mV}$, para as amostras com correntes de solda de 70 e 100A. Já o aço 316 apresentou uma variação um pouco maior nos valores de $\mathrm{E}_{\text {corr }} \mathrm{O}$ metal base foi a amostra que apresentou maior deslocamento de $\mathrm{E}_{\text {corr }}$; este valor foi diminuindo gradativamente à medida que aumentou-se a corrente de solda. Este comportamento é semelhante ao apresentado pelo metal sem revestimento, onde uma diminuição do $\mathrm{E}_{\text {corr }}$ com o aumento da corrente de solda também foi observado (Fig. 30 e Tab. 5). Assim como para os aços 304, não foram observados $\mathrm{E}_{\text {pite }}$ dentro do intervalo de potenciais estudado.

Os resultados eletroquímicos apresentados (Tab. 8 e 9) fornecem indícios de que houve uma melhora significativa no comportamento dos aços 304 e 316 com soldas, com respeito ao seu comportamento de corrosão em meio de cloreto. Para observar se efetivamente nenhum dano foi causado ao metal, ensaios de polarização potenciodinâmica foram realizados na amostra de aço 316 com solda de 100A (a qual apresentou um $\mathrm{E}_{\text {corr }}$ mais negativo dentre todas as amostras analisadas), porém utilizando a célula convencional. Esta análise foi feita nesta célula por abranger uma área maior da amostra e observar os possíveis danos causados pelo processo de corrosão; para esta análise não há interesse nos resultados dos parâmetros eletroquímicos de corrosão. Após este ensaio (Fig. 39a), a amostra exibe somente a marca da área demarcada pela célula, provocada devido à pressão desta contra a amostra, para efetuar a análise. Por análise visual não se observa danos causados ao revestimento; removendo-se este revestimento (Fig. 39b), observa-se, também por inspeção visual, que não há pites ou algum ataque visível sobre a amostra; em análise anterior, nas amostras sem o revestimento, estes danos eram facilmente visíveis. Na amostra sem o revestimento, as áreas analisadas foram destacadas com um círculo; em ambas as amostras, foram ilustradas nas figuras 40a e b, a posição do cordão de solda. Nas demais amostras, dos aços 304 e com outras correntes de solda, os resultados apresentados foram semelhantes a este. 


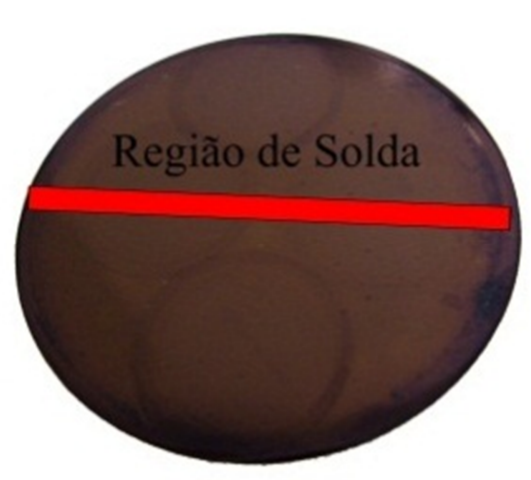

(a)

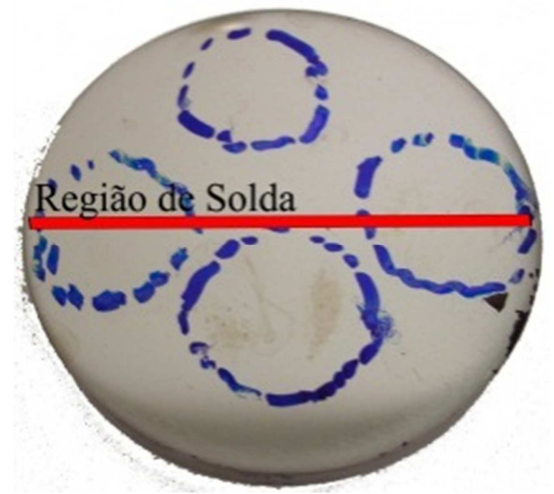

(b)

Figura 39 - Aço 316 com solda de 100 A após análise de polarização (célula convencional) em solução de $\mathrm{NaCl}$ 3,0\%. (a) Com revestimento de PAni e (b) após remoção do revestimento.

O método químico de síntese e deposição utilizado apresentou boa aderência e homogeneidade, mesmo sem o uso de agentes para aumentar aderência, como fosfato ou oxalato. Os resultados sugerem ainda que baixa porosidade do filme foi obtida, uma vez que não foi observado nenhum dano na superfície metálica, o que sugere que os íons cloreto, responsáveis pelo pite, não conseguiram penetrar pelo revestimento e atingir a superfície metálica. O estudo da deposição química da PAni é de grande importância, pois é diretamente aplicável na formulação de tintas e primers. A literatura apresenta diversos trabalhos de sínteses eletroquímicas em aços inoxidáveis [103-106]. Um dos motivos pelo qual a síntese eletroquímica é mais utilizada em aços inoxidáveis, em detrimento da síntese química, é porque nestes aços não é observado a formação de óxidos/hidróxidos insolúveis de ferro em quantidades apreciáveis, como ocorre nos aços carbono. Desta forma, torna-se mais viável a eletropolimerização, já que potenciais aplicados para oxidação dos monômeros de anilina oxidam também a superfície metálica, podendo aumentar também a aderência do revestimento.

Pelos resultados obtidos conclui-se que revestimentos a base de PAni quimicamente sintetizado se mostraram uma alternativa eficiente como revestimento protetor contra a corrosão de aços inoxidáveis. Durante as análises de polarização potenciodinâmica, o revestimento apresentou boa aderência ao metal, o que pode ser atestado pelos resultados apresentados. Assim, tanto metal como as diferentes soldas puderam ser protegidas contra a corrosão, e como resultado a presença de pites não foi observada. Uma vantagem em se utilizar aços inoxidáveis, é que eles têm a propriedade de formação da camada de passivação; conforme já discutido, a PAni, com seu caráter condutor, pode atuar no sentido de promover a formação desta camada de óxido, a qual, por ser aderente, protege o metal. Ressalta-se que, ainda que a camada de passivação dos aços inoxidáveis possui caráter protetor, ela não foi 
suficiente para evitar a formação de pites nas análises em meio de cloreto, sem recobrimentos adicionais.

Os mecanismos de corrosão em aços carbono, entretanto, são totalmente diferentes dos aços inoxidáveis, pois eles não formam uma camada passivadora; antes, esta camada é constituída por óxidos e/ou hidróxidos de Fe, que não apresentam aderência, sendo removido da superfície após sua formação, de forma contínua. Por isso, um estudo à parte da corrosão deste aço é apresentado em sessão posterior.

\subsubsection{Considerações parciais}

Pelos resultados apresentados nesta seção, pode ser concluído que uma alteração na cristalinidade é observada em metais com soldas. No caso dos aços inoxidáveis 304 e 316, esta mudança foi da fase austenítica para ferrítica, e no aço carbono, de ferrítica e cementita para perlita. Para fazer análises eletroquímicas de corrosão nas regiões de solda, um dispositivo pontual portátil constituído por uma minicélula (sensor pontual de corrosão) foi utilizado com sucesso, apresentando boa reprodutibilidade nas análises de aços inoxidáveis. As regiões de solda se mostraram menos suscetíveis com relação à corrosão, e maiores correntes de solda resultaram em maiores potenciais de pite, mostrando que a fase ferrita formada foi benéfica para diminuir a corrosão na zona de fusão da solda. Para proteger estes aços e suas soldas contra a corrosão, revestimentos protetores de PAni, sintetizados por via química, foram empregados com sucesso, evitando a formação de pites (nos ensaios de polarização) e deslocando os parâmetros eletroquímicos das análises para valores mais nobres. Contudo, o aço carbono apresenta mecanismo de corrosão diferente do aço inoxidável (pela formação de óxidos/hidróxidos de ferro insolúveis), sendo por isso bem mais suscetível à corrosão. Por este motivo, as sessões posteriores tratarão de uma análise sistemática e mais detalhada da corrosão da solda de aço carbono 1020, e o desenvolvimento de um revestimento protetor eficiente para inibir sua corrosão.

\subsection{Estudos eletroquímicos globais e localizados da influência da solda TIG na corrosão do aço carbono 1020}

Dentre os aços estudados, o aço carbono 1020 é o mais propício a sofrer corrosão, pois não possui nenhum elemento de liga que lhe permita criar uma camada passivadora, protetora da superfície metálica. A oxidação desse aço carbono gera um óxido de coloração 
avermelhada e não aderente, que não exerce uma proteção tão efetiva como a que ocorre nos aços inoxidáveis. Por isso, esse metal foi escolhido dentre os demais como objeto de análise de seu comportamento frente a corrosão em meio contendo cloreto. Este estudo foi realizando utilizando técnicas de corrosão globais (monitoramento do potencial de circuito aberto, PCA, e espectroscopia de impedância eletroquímica, EIE) e técnicas de corrosão localizadas (espectroscopia de impedância eletroquímica localizada, EIEL, e técnica do eletrodo vibratório de varredura, TEVV). Por meio destas técnicas foi possível fazer uma varredura da superfície analisada, e desta forma foi traçado uma mapa de toda superfície por valores de impedância (EIEL), ou densidade de corrente de corrosão (TEVV); nesta última técnica, as regiões catódicas e anódicas são diferenciadas.

O eletrodo de trabalho usado nestes experimentos foi um eletrodo duplo, descrito na seção experimental, com o qual foi possível analisar as regiões de solda e do metal base, isoladamente, ou conectadas eletricamente. Além disso, este tipo de eletrodo possui uma configuração requerida para as análises de corrosão localizadas, como limitação da área de trabalho e uma superfície isolante no entorno do metal analisado. As amostras de aço carbono 1020 foram soldadas pelo método TIG, com corrente de solda de 100A DC, conforme já descrito na parte experimental; o polimento foi feito como descrito, entretanto para esta parte foi utilizado lixas até \#2400.

\subsubsection{Análise de PCA}

Inicialmente, foram feitas análises de monitoramento do PCA das regiões de solda e metal base, isoladamente, e das duas regiões conectadas eletricamente. A variação do PCA está apresentada na Fig. 40 para o metal base, solda, e as duas regiões conectadas eletricamente. Pela análise, observa-se que para todas as regiões do metal, o PCA diminui com o tempo, indicando um processo de corrosão em todos os eletrodos. Este comportamento também foi observado por Cáceres et al. [107], os quais, estudando a corrosão de aço carbono em soluções com diferentes concentrações de cloreto, observaram que sempre ocorre uma diminuição do PCA nas amostras. Ainda de acordo com a Fig. 40, a região de solda apresentou sempre menores valores de PCA que as demais, mostrando que é um material menos nobre, enquanto que o metal base apresentou os maiores valores em todos os tempos, mostrando que é um material mais nobre. Os dois eletrodos conectados apresentaram valores intermediários aos metais individuais. 


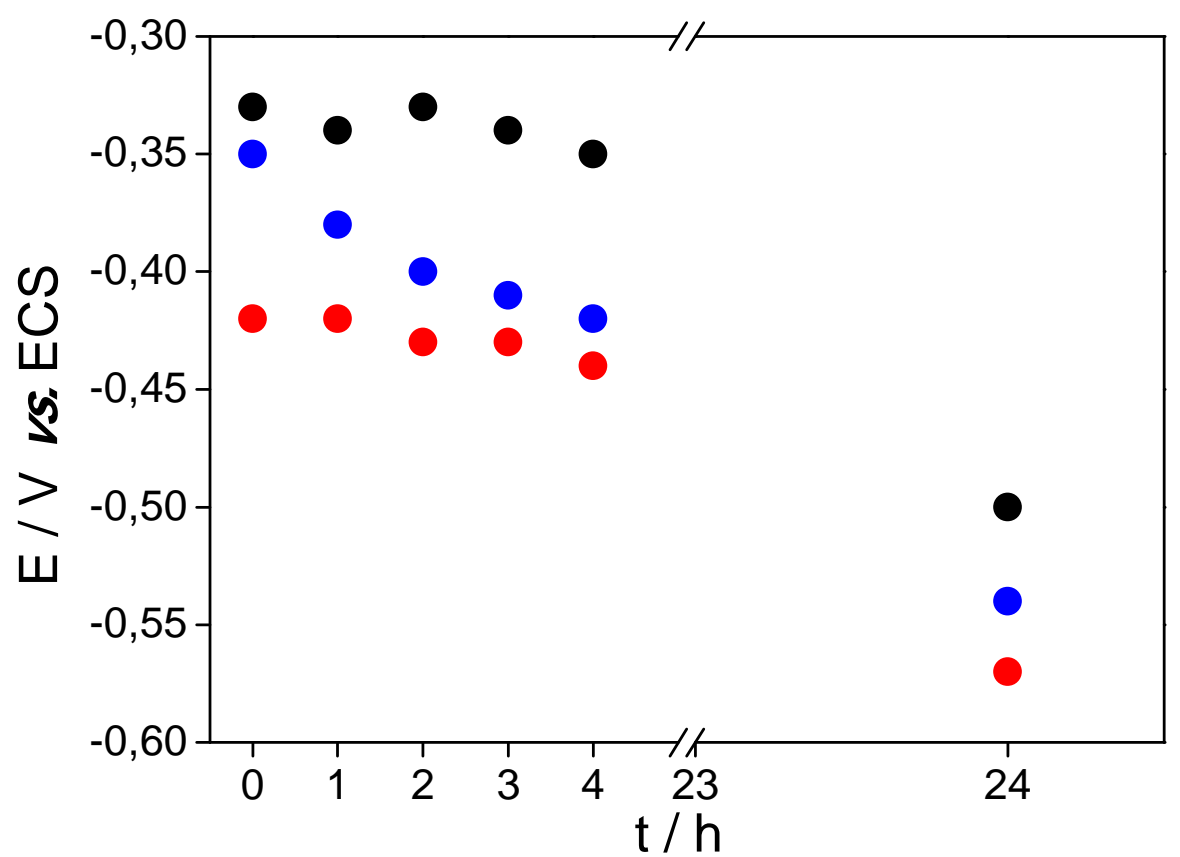

Figura 40 - Análise de PCA em aço carbono 1020, em solução de $\mathrm{NaCl}$ 1,0 mmol L ${ }^{-1}$, das regiões de: (•) solda, $(\bullet)$ metal base e $(\bullet)$ eletrodos conectados.

A solda se mostrou ser o material mais ativo, apresentando sempre os menores valores de PCA sendo que a diferença de potencial entre os eletrodos é aproximadamente a mesma em todos os tempos, indicativo de que a evolução da corrosão é paralela entre eles. Este resultado trouxe um primeiro indício de que, diferentemente dos aços inoxidáveis, a corrosão no aço carbono está ocorrendo em maior grau na região de solda. Esta diferença é atribuída à mudança de microestrutura do metal na região de solda e uma possível corrosão no contorno de grão. Além disso, é possível que haja diferenças na composição química das regiões de solda e metal base, pela ausência de metais que provocam passivação. Assim, pode ocorrer um maior efeito de segregação de elementos e da microestrutura.

\subsubsection{Análise por EIE}

Análises de EIE foram realizadas nas diferentes amostras (solda, metal base e eletrodos conectados) utilizando intervalos de frequência de $10 \mathrm{mH}$ a $100 \mathrm{kHz}$, com amplitude de 10 $\mathrm{mV}$ rms. Os resultados estão expressos por seus respectivos diagramas de Nyquist (Fig. 41) e de Bode (Fig. 42). O comportamento observado por esses gráficos, pelos diagramas de Nyquist, é de uma constante de tempo, e característico de processo de transferência de carga. Assim, utilizando um circuito de Randles simples (Fig. 43) com uma resistência do eletrólito $\left(R_{s}\right)$, uma resistência de transferência de carga $\left(R_{t c}\right)$ e um elemento de fase constante (CPE), 
foi feito o ajuste para cada curva utilizando o software ZVIEW 2.9 (Fig. 42). Todas as curvas experimentais apresentaram um comportamento capacitivo, com apenas uma constante de tempo. Os parâmetros eletroquímicos dos ajustes estão mostrados na tabela 10. Os resultados eletroquímicos obtidos nas análises de EIE são da mesma ordem de grandeza dos parâmetros obtidos por Ren et al.[108] que estudaram a influência entre o estresse mecânico provocado no metal e sua corrosão. Pode-se observar que a resistência da solução é um parâmetro praticamente constante para a solda e o metal base (aproximadamente $1 \mathrm{k} \Omega \mathrm{cm}^{2}$ ). Para os eletrodos conectados, esta resistência é ligeiramente maior (aproximadamente $1,3 \mathrm{k} \Omega \mathrm{cm}^{2}$ ). O alto valor da $\mathrm{R}_{\mathrm{S}}$ se justifica pelo baixa concentração de $\mathrm{Cl}^{-}$presente na solução $\left(1,0 \mathrm{mmol} \mathrm{L}{ }^{-1}\right)$. $\mathrm{O}$ valor de $\mathrm{R}_{\mathrm{tc}}$ é menor na solda, e os eletrodos conectados apresentam, em geral, valores intermediários. A capacitância é maior para a solda, sendo que todos os eletrodos aumentam seus valores de capacitância com o tempo (Fig. 44).

Análises de EIE foram feita nas amostras (solda, metal base e eletrodos conectados), utilizando intervalos de frequência de $10 \mathrm{mH}$ a $100 \mathrm{kHz}$, com amplitude de $10 \mathrm{mV}$; os resultados foram expressos por seus respectivos diagramas de Bode (Fig. 42). Os gráficos de EIE são característicos de um processo de transferência de carga; utilizando um circuito de Randles simples (Fig. 43), com uma resistência do eletrólito $\left(\mathrm{R}_{\mathrm{s}}\right)$, uma resistência de transferência de carga $\left(\mathrm{R}_{\mathrm{tc}}\right)$ e um elemento de fase constante $(\mathrm{CPE})$, foi feito um ajuste para cada curva, utilizando o software ZVIEW 2.9 (os ajustes já se encontram nos gráficos das Fig. 41 e 42). Todas as curvas experimentais apresentaram um comportamento capacitivo, com apenas uma constante de tempo. Os parâmetros eletroquímicos dos ajustes estão mostrados na tabela 10. Os resultados eletroquímicos obtidos nas análises de EIE são da mesma ordem de grandeza dos parâmetros obtidos por Ren et al. [108], estudando a influência entre o estresse mecânico provocado no metal e sua corrosão. Pela tabela pode-se observar que a resistência da solução é um parâmetro praticamente constante para a solda e o metal base (aproximadamente $1 \mathrm{k} \Omega \mathrm{cm}^{-2}$ ). Para os eletrodos conectados, esta resistência é ligeiramente maior (aproximadamente $1,3 \mathrm{k} \Omega \mathrm{cm}^{-2}$ ); a $\mathrm{R}_{\mathrm{tc}}$ é menor na solda, e os eletrodos conectados apresentam, em geral, valores intermediários. A capacitância é maior para a solda, sendo que todos os eletrodos aumentam seus valores de capacitância com o tempo (Fig. 44). 


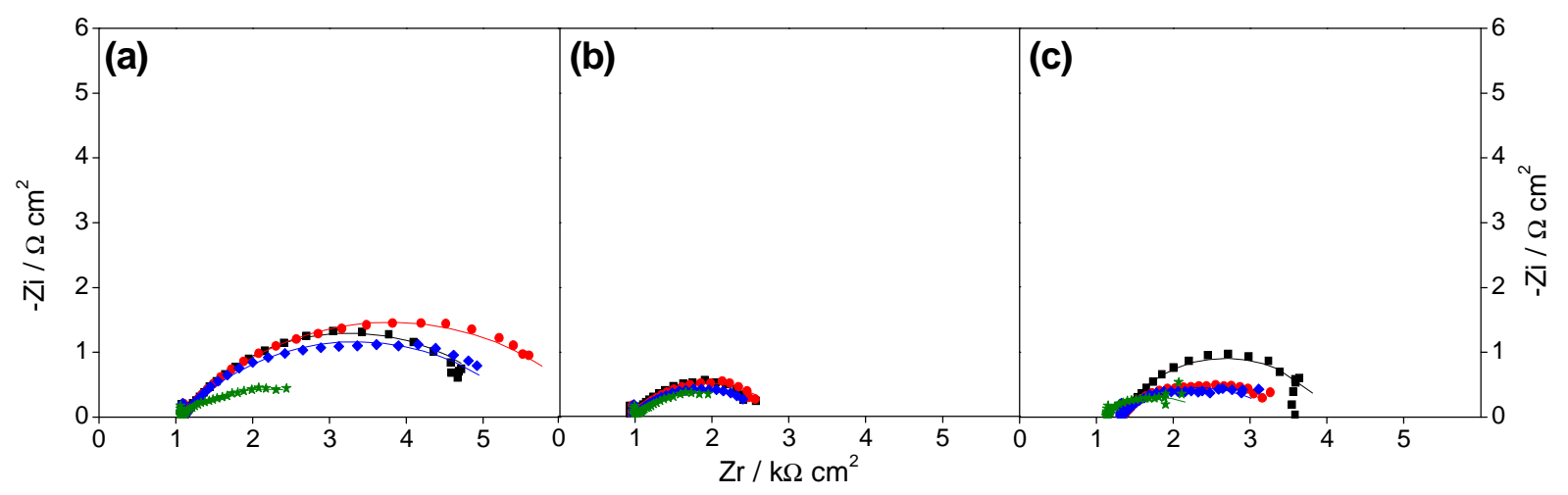

Figura 41 - Diagrama de Nyquist de análise de EIE em aço carbono 1020, em solução de $\mathrm{NaCl} 1,0$ mmol L'-1, das regiões de: (a) metal base, (b) solda e (c) eletrodos conectados. Tempos de imersão (dados experimentais): (•) 0, $(\bullet) 2,(\bullet) 4$ e (•) 24h; as linhas são os ajustes feitos em software ZVIEW.

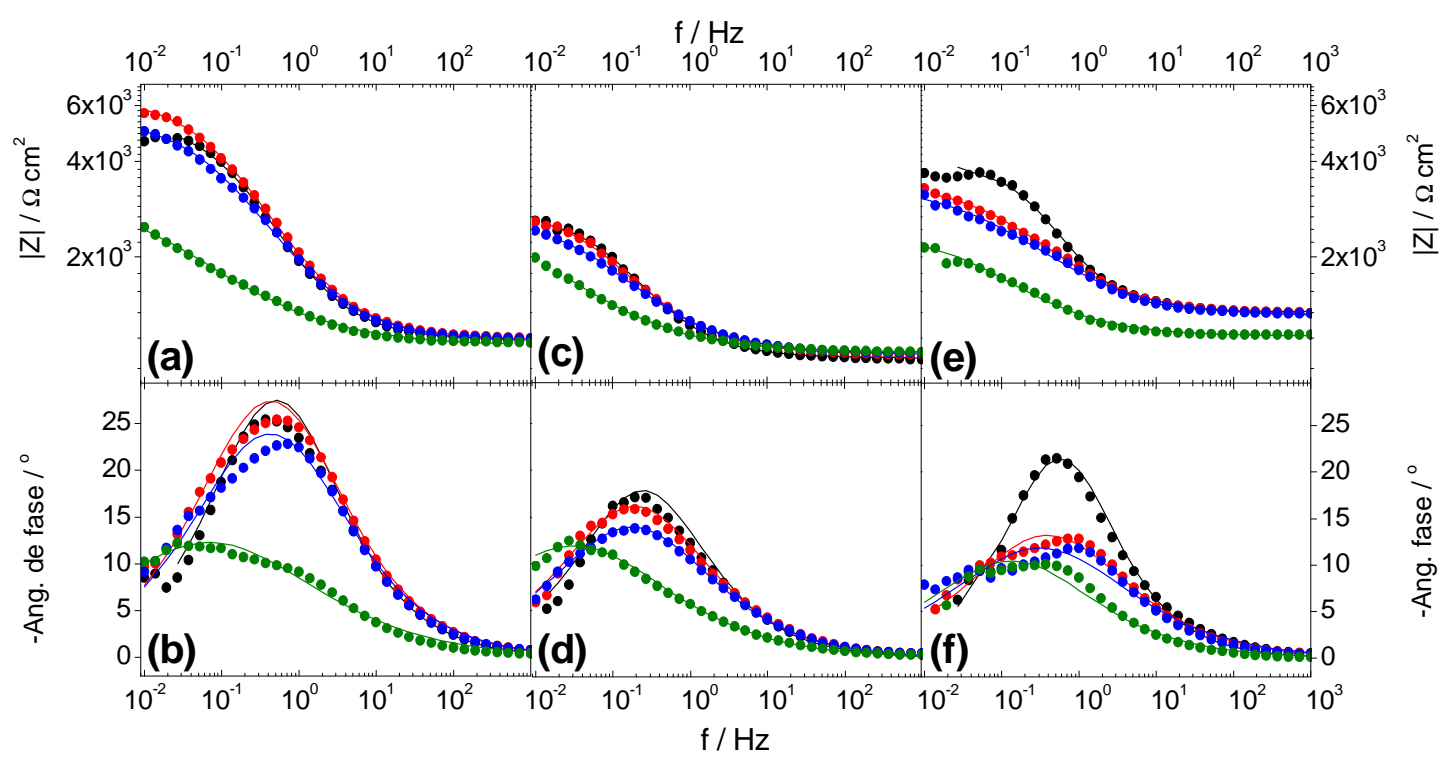

Figura 42 - Diagrama de Bode de análise de EIE em aço carbono 1020, em solução de $\mathrm{NaCl} 1,0$ mmol L ${ }^{-1}$, das regiões de: (a) e (b) metal base; (c) e (d) solda e (e) e (f) eletrodos conectados. Tempos de imersão (dados experimentais): $(\bullet) 0,(\bullet) 2,(\bullet) 4$ e (•) 24h; as linhas são os ajustes feitos em software ZVIEW.

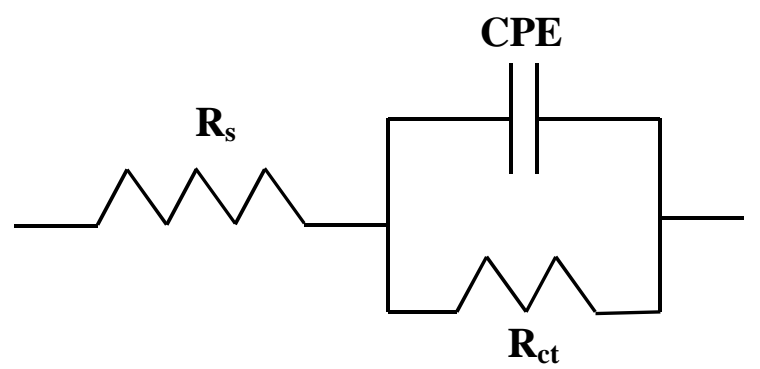

Figura 43 - Modelo de circuito elétrico (circuito de Randles) utilizado para fazer os ajustes nas curvas experimentais de EIE (Fig. 42). 


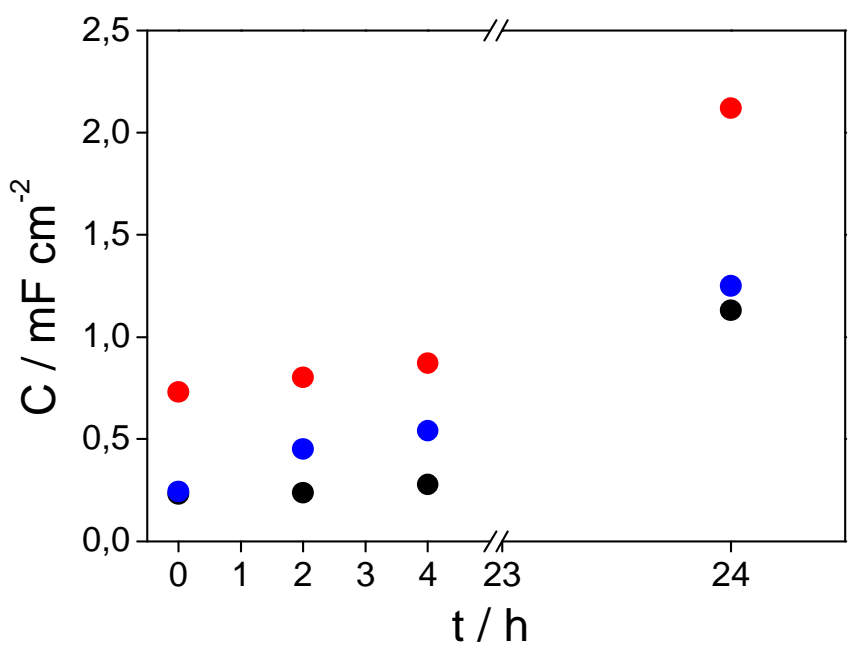

Figura 44 - Variação da capacitância com o tempo das regiões de: $(\bullet)$ solda, $(\bullet)$ metal base e $(\bullet)$ eletrodos conectados (valores obtidos da Tabela 10).

Tabela 10 - Parâmetros eletroquímicos obtidos a partir dos ajustes das análises de EIE do aço carbono 1020 (Fig. 41 e 42$)$

\begin{tabular}{|c|c|c|c|c|}
\hline Parâmetros & $\mathbf{t}=\mathbf{0} \mathbf{h}$ & $t=2 h$ & $t=4 h$ & $t=24 h$ \\
\hline \multicolumn{5}{|c|}{ Solda } \\
\hline $\mathbf{R}_{\mathrm{s}} / \mathrm{k} \mathbf{\Omega} \mathbf{c m}$ & 0,957 & 0,982 & 0,980 & 0,994 \\
\hline $\mathbf{R}_{\mathrm{tc}} / \mathrm{k} \boldsymbol{\Omega} \mathbf{c m}$ & 1,80 & 1,94 & 1,80 & 1,91 \\
\hline $\mathrm{C} / \mathrm{mF} \mathrm{cm}^{-2}$ & 0,730 & 0,802 & 0,873 & 0,212 \\
\hline $\mathbf{n}$ & 0,68 & 0,62 & 0,57 & 0,49 \\
\hline \multicolumn{5}{|c|}{ Metal base } \\
\hline $\mathbf{R}_{\mathrm{s}} / \mathrm{k} \Omega \mathbf{c m}$ & 1,10 & 1,10 & 1,08 & 1,05 \\
\hline $\mathbf{R}_{\mathrm{tc}} / \mathrm{k} \boldsymbol{\Omega} \mathbf{c m}$ & 4,34 & 5,38 & 4,51 & 2,29 \\
\hline $\mathrm{C} / \mathrm{mF} \mathrm{cm}^{-2}$ & 0,231 & 0,239 & 0,278 & 0,113 \\
\hline $\mathbf{n}$ & 0,69 & 0,63 & 0,60 & 0,46 \\
\hline \multicolumn{5}{|c|}{ Eletrodos conectados } \\
\hline $\mathbf{R}_{\mathrm{s}} / \mathbf{k} \boldsymbol{\Omega} \mathbf{c m}^{2}$ & 1,34 & 1,32 & 1,30 & 1,13 \\
\hline $\mathbf{R}_{\mathrm{tc}} / \mathbf{k} \boldsymbol{\Omega} \mathbf{c m}^{2}$ & 2,69 & 2,12 & 2,08 & 1,31 \\
\hline $\mathrm{C} / \mathrm{mF} \mathrm{\mathbf {cm } ^ { - 2 }}$ & 0,245 & 0,452 & 0,542 & 1,25 \\
\hline $\mathbf{n}$ & 0,76 & 0,57 & 0,52 & 0,56 \\
\hline
\end{tabular}


As análises mostram um comportamento resistivo-capacitivo para todos os eletrodos. A resistência de transferência de carga apresentou menores valores para a solda, e maiores valores para o metal base (Tabela 10). Estes valores confirmam que a solda é mais susceptível à corrosão que o metal base. Para melhor comparação entre o metal base e a solda, a Fig. 45 mostra as curvas de impedância para os eletrodos após $2 \mathrm{~h}$ de imersão em $\mathrm{NaCl}$. Por este gráfico é possível visualizar com mais clareza que o metal base, com maior $\mathrm{R}_{\mathrm{tc}}$ (observável na região de baixas frequências), é menos ativo que a solda, que possui menor valor de $\mathrm{R}_{\mathrm{tc}}$. Os eletrodos conectados, por simetria, apresentaram valores intermediários aos dois primeiros.

Pelos resultados apresentados na Fig. 44 observa-se que o valor de $\mathrm{R}_{\mathrm{tc}}$ aumentou para a solda e o metal base devido à formação de uma camada de óxido sobre o metal. A capacitância da solda é sempre maior que o metal base, e este valor aumenta com o tempo de imersão. Entretanto, devido ao caráter poroso e não aderente da camada de óxido formada, $R_{t c}$ não continua aumentando, e após $4 \mathrm{~h}$ em solução de $\mathrm{NaCl}$ o parâmetro $\mathrm{R}_{\mathrm{tc}}$ começa a diminuir. Após 24 h, este parâmetro atinge o menor valor para o metal base. Para a solda, $R_{t c}$ apresenta flutuações com o tempo e este comportamento (não observado no metal base) demonstra uma tendência de alta susceptibilidade à corrosão, com a formação de uma camada de óxido sobre o aço promovendo a proteção temporária na solda (diminuindo o valor de $\mathrm{R}_{\mathrm{tc}}$ ). Entretanto, com o desprendimento desta camada, o aço fica novamente exposto à solução, até que outra camada seja formada (neste momento, uma diminuição no valor de $\mathrm{R}_{\mathrm{tc}}$ é observada). Para os eletrodos conectados, observa-se aumento e diminuição nos valores de $\mathrm{R}_{\mathrm{tc}}$. Uma vez que este resultado é obtido simultaneamente a partir de dois eletrodos com comportamentos diferentes (solda e metal base), é plausível que ocorra aumento e diminuição dos valores da $\mathrm{R}_{\mathrm{tc}}$, sendo que, após $24 \mathrm{~h}$, este valor também diminui, da mesma forma como observado para os eletrodos separados. 


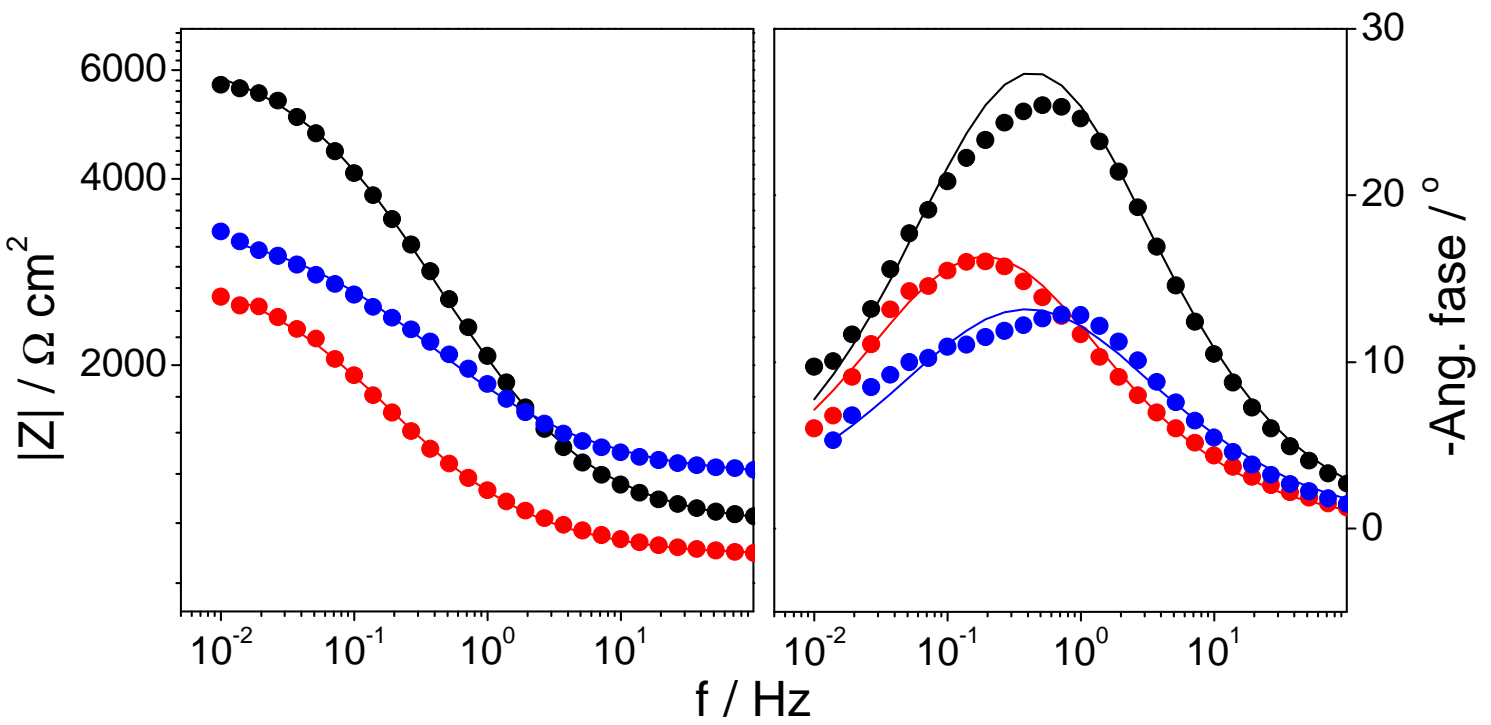

Figura 45 - Diagrama de Bode após 2h de imersão do aço carbono $1020 \mathrm{em} \mathrm{NaCl} \mathrm{1,0} \mathrm{mmol} \mathrm{L} \mathrm{m}^{-1}$ das regiões de: $(\bullet)$ solda, $(\bullet)$ metal base e $(\bullet)$ eletrodos conectados.

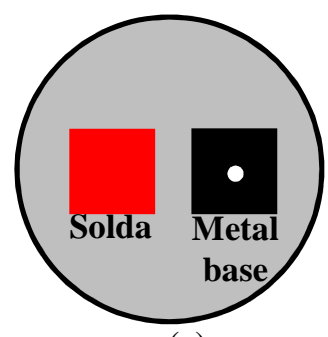

(a)

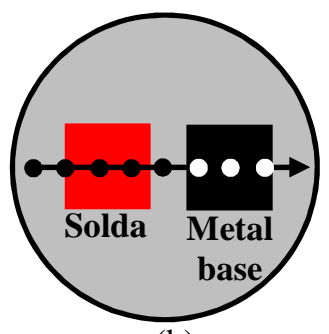

(b)

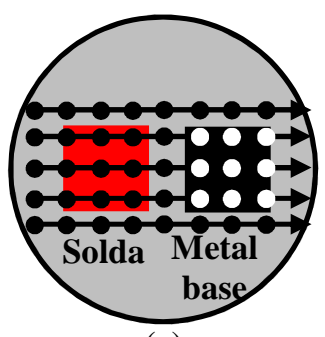

(c)

Figura 46 - Tipos de medidas feitas nas análises de corrosão localizadas (EIEL e TEVV) utilizando o eletrodo duplo: (a) análise pontual, (b) análise por linha (unidimensional) e (c) mapeamento (bidimensional).

\subsubsection{Análise por EIEL}

A espectroscopia de impedância eletroquímica localizada (LEIS) permite fazer análises de impedância a uma determinada frequência, ao longo de uma amostra. Desta forma, é possível obter um mapeamento desta amostra por meio de sua impedância a determinada frequência. Três tipos de análises podem ser feitos nas amostras: pontual, linha e mapeamento (Fig. 46).

A análise pontual apresenta um resultado semelhante a uma análise de EIE convencional, podendo ser feita de forma a abranger o espectro de frequências desejado. Uma linha também pode ser obtida com a realização de várias medidas de impedância (a uma única frequência) ao longo de uma região previamente escolhida sobre a amostra (Fig. 46b). Por fim, um mapeamento que consiste de várias linhas paralelas "desenhando" a superfície em 


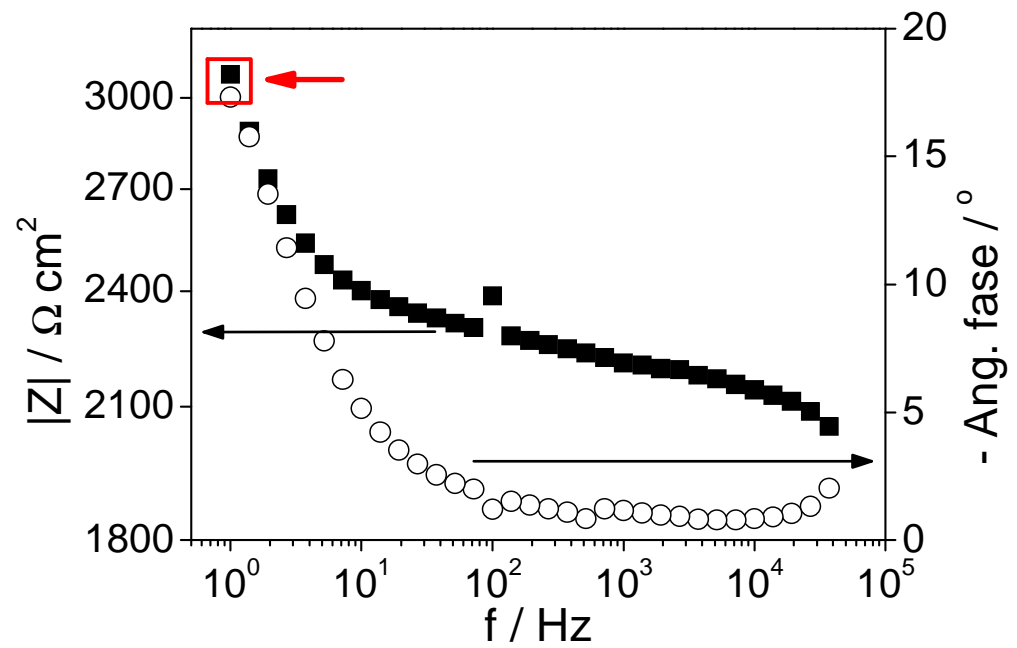

Figura 47 - Espectro de EIEL pontual, feito em $\mathrm{NaCl} 1,0 \mathrm{mmol} \mathrm{L}^{-1}$ sobre o metal base (aço carbono 1020) a $\mathrm{t}=0 \mathrm{~h}$.

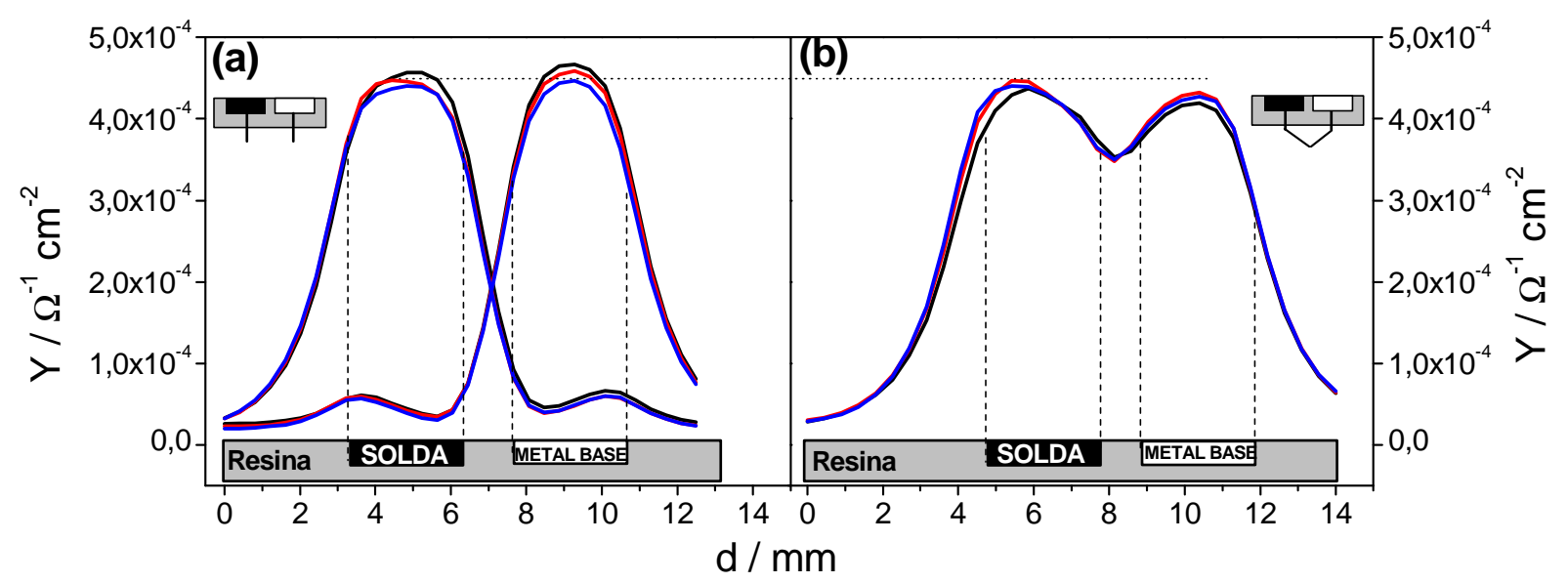

Figura 48 - Análise por EIEL (linha, bidimensional), feito sobre aço carbono 1020 à frequência de 1,0kHz, em $\mathrm{NaCl}$ 1,0 mmol L $\mathrm{m}^{-1}$. (a) solda e metal base, desconectados e (b) eletrodos conectados. Tempos de imersão: -0 , $-2 \mathrm{e}-4 \mathrm{~h}$.

termos da sua impedância (Fig. 46c) e, assim como na linha, somente pode ser feito a um único valor de frequência. Fatores como velocidade de varredura e número de pontos são importantes e devem ser otimizados, pois um maior número de pontos, à medida que oferece maior precisão na análise, demora mais tempo para ser concluído. E, como se trata de análise de um processo de corrosão em ambiente agressivo (cloreto), este fenômeno evolui rapidamente com o tempo, não sendo interessante uma análise muito demorada. 


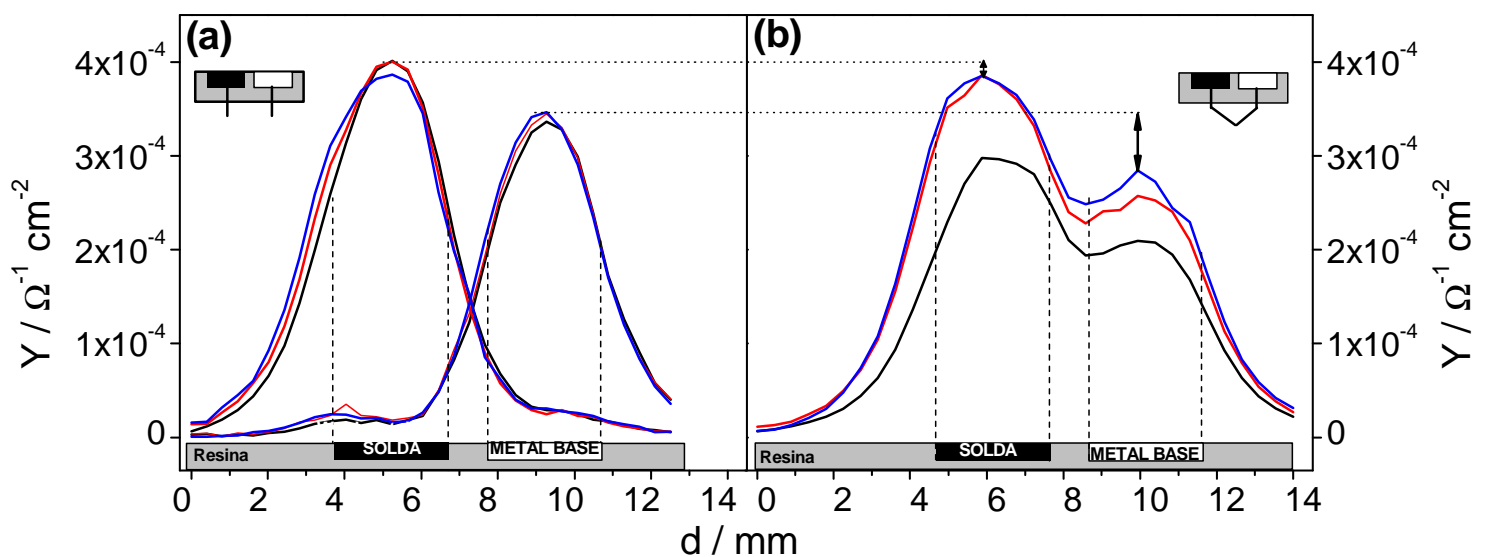

Figura 49 - Análise por EIEL (linha, bidimensional), feito sobre aço carbono 1020 a frequência de 1,0Hz, em $\mathrm{NaCl}$ 1,0 mmol L $\mathrm{m}^{-1}$. (a) solda e metal base, desconectados e (b) eletrodos conectados. Tempos de imersão: -0 , $-2 \mathrm{e}-4 \mathrm{~h}$.

Inicialmente foi feita uma análise pontual de impedância em um determinado intervalo de frequências sobre o metal base (Fig. 46a). Esta análise foi feita para determinar uma frequência que se encontrasse na região capacitiva da amostra, a fim de escolher um valor que reflita propriedades da superfície da amostra, e não da solução (o que ocorre a altas frequências). Espera-se uma semelhança no comportamento dos eletrodos apresentados nas análises de EIE (convencional), contudo diferenças nos espectros são justificadas, uma vez que ambas se valem de princípios físicos diferentes para as medições (anexo 1).

Um espectro obtido por EIEL é apresentado na Fig. 47, na forma de diagrama de Bode. Um quadrado vermelho foi usado neste gráfico para destacar a região capacitiva do espectro, a uma frequência de aproximadamente $1 \mathrm{~Hz}$. Assim, esta provavelmente será a frequência que expressará propriedades da interface do eletrodo.

Uma primeira análise de EIEL do tipo linha foi feita sobre a amostra, inicialmente a alta frequência (1,0 kHz, Fig. 48). Pelo resultado pode-se observar que, ambas as montagens dos eletrodos, isolados (Fig. 48a) e conectados (Fig. 48b), apresentam aproximadamente a mesma admitância, tanto para a solda como para o metal base. A variação do valor da admitância com o decorrer do tempo também foi muito pequena, podendo-se considerar praticamente constante. Este comportamento se deve ao fato que altos valores de frequência correspondem às propriedades da solução. Evidentemente, como a solução utilizada é a mesma em todos os casos, praticamente não se observa diferença nenhuma entre a região de solda e do metal base, tanto isolados como conectados. 


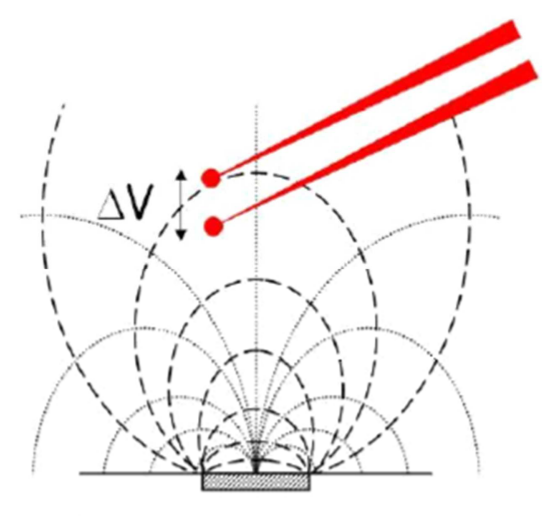

Figura 50 - Linhas de campo de um eletrodo embutido em uma superfície isolante devido a um processo de corrosão [78].

Uma segunda análise de EIEL foi feita, desta vez utilizando baixo valor de frequência $(1,0$ Hz, Fig. 49). Na análise com os eletrodos isolados (Fig. 49a), os resultados mostraram maiores valores de admitância para a solda. Isto mostra que este eletrodo é mais suscetível aos processos de corrosão que seu metal base, não somente pela análise de EIE convencional, mas também pela análise de impedância localizada. Quando a mesma análise foi feita com os eletrodos conectados (Fig. 49b), a solda também apresentou maior corrosão que o metal base. A diferença entre estas duas medidas é que, quando os eletrodos estão eletricamente conectados, a admitância na região do metal base é bem menor do que quando os eletrodos são medidos individualmente. Isto representa uma diminuição na corrosão do metal base, o que sugere também um indício de estas regiões estão formando um par galvânico.

$\mathrm{Na}$ análise feita a baixa frequência (Fig. 49), observa-se também uma maior variação nos valores de admitância entre a primeira medida $(\mathrm{t}=0 \mathrm{~h})$ com as demais. Para os eletrodos isolados (Fig. 49a), praticamente não se observa variação nos valores de admitância entre os diferentes tempos, mostrando que efeitos mais pronunciados ocorrem, de fato, com os eletrodos conectados.

Uma última observação com relação a estas análises, é que se observa pequenos picos nas análises dos eletrodos isolados (Figs. 48a e 49a). Estes picos são referentes ao eletrodo que não está sendo analisado. Embora ele não está conectado ao contato do eletrodo de trabalho do equipamento, sua corrosão está ocorrendo, e as linhas de campo derivado deste processo do eletrodo não analisado é sentida pelo sensor que faz a varredura ao longo dos eletrodos. Este fato justifica também a observação que as linhas de admitância observadas em todas as análises (Figs. 48 e 49) não se iniciam e terminam simetricamente junto com o início e o fim dos eletrodos. Estas linhas se iniciam próximo do primeiro eletrodo, porém antes de 
estar posicionado sobre este, e da mesma forma só terminam após a sonda já ter varrido todo o eletrodo, quando já está sobre a resina. Este comportamento se deve ao fato que as linhas de campo que emergem do eletrodo devido à corrosão se estendem para além de sua superfície (Fig. 50), resultando em um aumento e término exponencial das linhas, para além das regiões do eletrodo.

\subsubsection{Análises pela técnica do eletrodo vibratório de varredura}

Com as análises feitas até aqui, é possível concluir que a solda possui maior susceptibilidade aos processos de corrosão que o metal base em solução de cloreto. Entretanto, é importante saber se esta corrosão somente está ocorrendo nos dois eletrodos em velocidades diferentes, ou se a união dos dois eletrodos forma um par galvânico bem definido, e, neste caso, ocorre a formação de um ânodo e um cátodo pela alteração da microestrutura do metal na região de solda.

Para esclarecer esse ponto foram realizadas medidas de TEVV em solução de $\mathrm{NaCl}$ 0,05 mol L $\mathrm{L}^{-1}$ (a concentração foi selecionada para melhor visualização dos resultados pretendidos), no modo de varredura bidimensional (de forma a obter um mapeamento da superfície, como na Fig. 46c). Todas as análises foram feitas com os eletrodos conectados eletricamente, já que o objetivo desta análise, além de avaliar as correntes de corrosão, é avaliar a ocorrência de par galvânico entre as duas regiões. Simultaneamente às análises de TEVV, imagens de microscopia óptica foram também obtidas, por meio do microscópio óptico acoplado ao equipamento de TEVV, permitindo obter fotos simultâneas durante as medidas.

Os resultados obtidos pelas análises de TEVV são representados em um gráfico $2 \mathrm{D}$ ou 3D, com uma escala de cores. Por definição, a cor azul representa zonas catódicas e a cor vermelha, as zonas anódicas, sendo que a escala de cores indica a intensidade das correntes de corrosão. A Fig. 51 apresenta os resultados obtidos para a condição inicial, em t $=0$ h. Desta imagem pode-se concluir que a alteração do aço carbono pela aplicação de solda, junto de seu respectivo metal base, efetivamente formou um par galvânico, em que a solda é o ânodo, e o metal base, o cátodo. Para efeito de comparação, para cada tempo de imersão analisado $(0,2$, 4, 8 e 12h) foi construída uma figura contendo a microscopia, o mapa 2D de TEVV e a posição dos eletrodos (Fig. 52). 


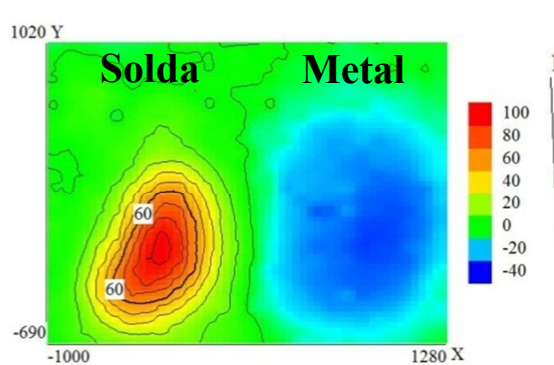

(a)

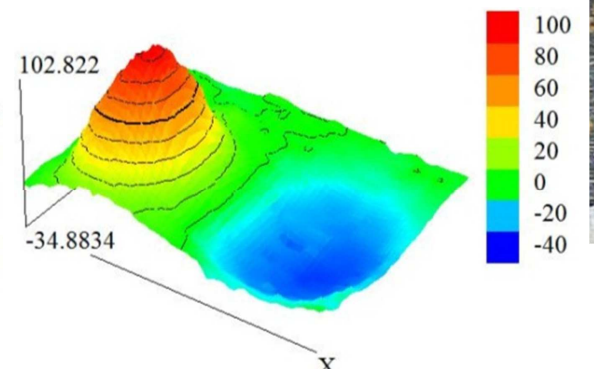

(b)

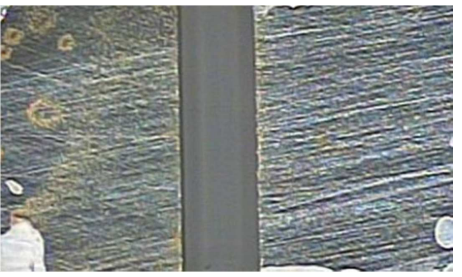

Solda Metal base

Figura 51 - Análise pela TEVV sobre aço carbono 1020, em $\mathrm{NaCl} 0,005 \mathrm{~mol} \mathrm{~L}^{-1}$ para t=0h da solda e metal base conectados: mapas (a) bidimensional e (b) tridimensional, e (c) microscopia óptica.

Para todos os tempos analisados (Fig. 52), os mapas de TEVV mostram uma região anódica (região de solda) e outra catódica (região do metal base). Os mapas também mostram altas correntes de corrosão anódicas (no eletrodo da solda) quando a análise se inicia (Fig. 52a), devido à alta susceptibilidade do aço carbono aos processos de corrosão em meio de cloreto, e pela não formação de uma camada de passivação. Imagens de microscopia mostram um filme alaranjado atribuído a hidróxidos de ferro (que oferecem pouca proteção à superfície por ser uma camada não aderente), o qual é frequentemente observado em estudos de corrosão de aço carbono em meio de solução de cloreto [107,109, 110].

Em contraste à região de solda, no metal base não é observada a presença de produtos de oxidação do ferro. Após 2 h de imersão em solução de cloreto (Fig. 52b) a corrente anódica aumenta, assim como a corrente catódica, indicando o progresso do processo de corrosão (Eq. 23, reação anódica) na solda e de seu processo complementar no metal base (Eq. 24, reação catódica):

$$
\begin{aligned}
& \mathrm{Fe}_{(\mathrm{s})} \rightarrow \mathrm{Fe}^{2+}{ }_{(\mathrm{aq})}+2 \mathrm{e}^{-} \\
& \mathrm{O}_{2(\mathrm{aq})}+\mathrm{H}_{2} \mathrm{O}+4 \mathrm{e}^{-} \rightarrow 4 \mathrm{OH}^{-}(\mathrm{aq})
\end{aligned}
$$

Após 4 h de imersão (Fig. 52c), a corrosão atingiu uma área maior (no ânodo) com diminuição da corrente anódica, mas com pouca alteração da corrente catódica. Isto pode indicar que o processo de corrosão não cessou, mas a camada de óxido não aderente derivada da corrosão do aço dificultou a medida da corrente (anódica) de corrosão. Neste caso, uma forma de estimar a corrosão, é pelo grau com que a reação catódica está ocorrendo (metal base). Após 8 e 12 h de imersão em solução (Fig. 52d-e), o processo permaneceu estável, ou seja, não houve aumento significativo da corrente de corrosão da solda, ao passo que a corrente de corrosão do metal base se manteve com maior intensidade. 

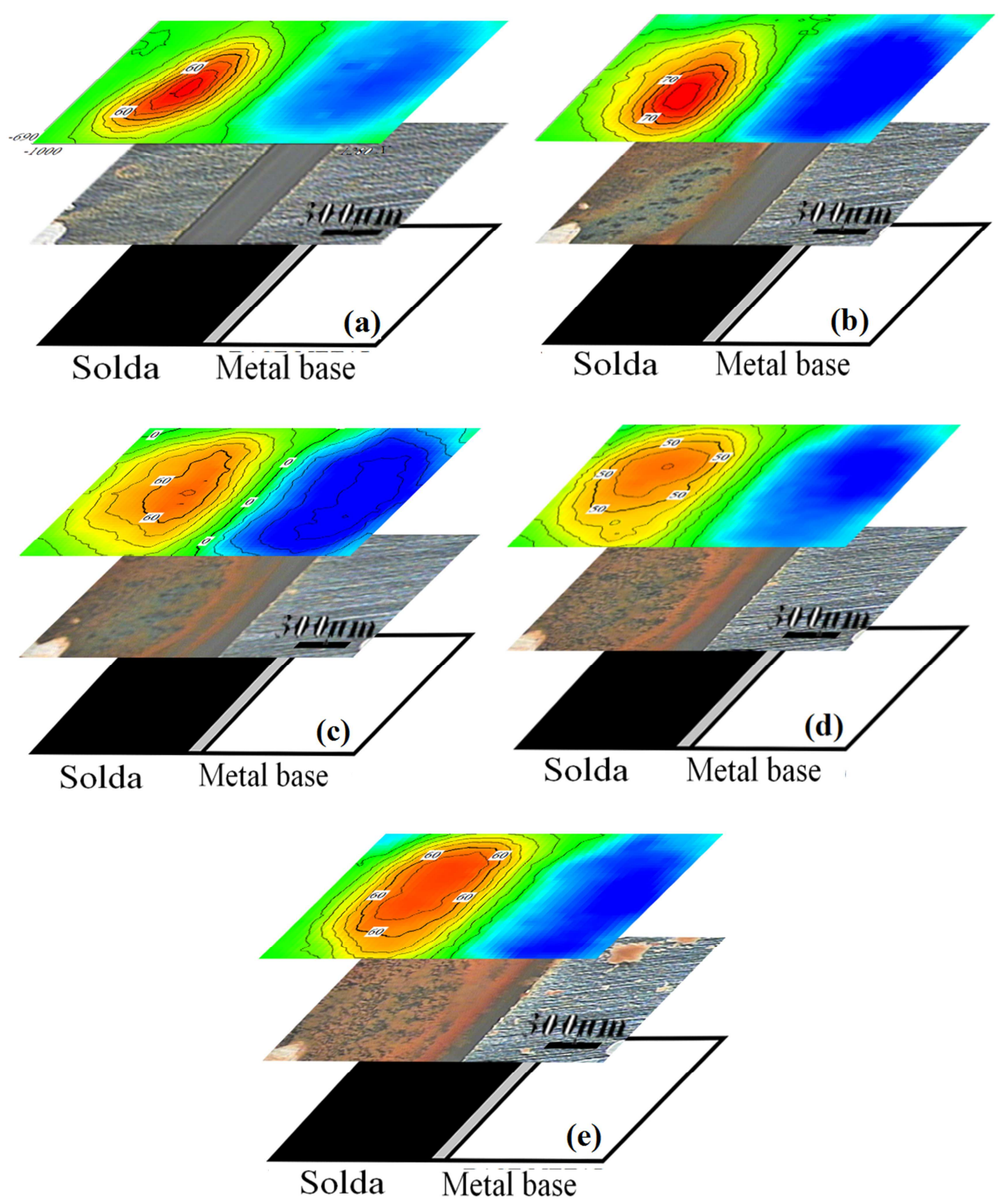

Figura 52 - Análises pela TEVV e MO em aço carbono 1020, e posição dos eletrodos (eletricamente conectados), imersos em solução de $\mathrm{NaCl}$ 0,005 $\mathrm{mol} \mathrm{L}^{-1}$ por (a) 0 , (b) 2, (c) 4, (d) 8 e (e) $12 \mathrm{~h}$.

Segundo Cáceres et al. [107] o processo de corrosão em um aço carbono pode ser descrito em função de suas reações catódica e anódica (Eqs. 18 e 19). A dissolução do Fe (reação anódica) é um processo de transferência de carga controlado cineticamente; já a reação de redução do $\mathrm{O}_{2}$ é controlada por dois mecanismos simultâneos, a transferência de massa e a transferência de carga, ambos com controle cinético. A formação de pites resulta em aumento da área disponível para a reação anódica; entretanto, a formação do óxido inibe a 
reação catódica, diminuindo assim a corrente deste processo. No balanço das reações, a inibição do processo catódico não permite que, mesmo com o aumento da área para ocorrência do processo anódico, a taxa de corrosão aumente mas, pelo contrário, a tendência é que ela diminua. Este fato foi observado nestes resultados, em que ocorre uma pequena diminuição do processo catódico, mas, em contrapartida, uma diminuição mais acentuada do processo anódico. A formação de pites, embora seja mais frequente em metais em que ocorre passivação, também ocorre em aços carbono, onde o fenômeno da passivação não é observado.

Lin et al. [111] utilizaram a técnica de corrosão localizada para mapear o potencial de corrosão de uma amostra de aço carbono, em meio de solução de cloreto. Os mapas de potenciais da superfície apresentaram picos, os quais foram relacionados pelos autores como regiões de formação de pites. A intensidade e localização destes picos variaram com o tempo de imersão. Esta observação foi justificada pelos autores como sendo a formação de micro pites metaestáveis, de ocorrência randômica e instantânea sobre a superfície, sendo a presença de tais pites confirmada por meio de MEV. A ocorrência de pites neste tipo de material, segundo os autores, ocorre em inclusões de $\mathrm{MnS}$, pois são os locais em que os íons cloreto preferencialmente se adsorvem e se acumulam. Os pites metaestáveis que se formam, segundo os autores, dão origem a macro pites, responsáveis pela corrosão. Ainda, a formação dos pites metaestáveis está associada com a concentração local de íons cloreto.

Pela Fig. 52 observa-se um pico grande e bem definido na área anódica. Em um eletrodo imerso em solução aquosa, onde está ocorrendo um processo de corrosão, se estabelece um campo elétrico na superfície deste eletrodo. A ponta de prova do TEVV detecta, na verdade, o gradiente das linhas de campo estabelecidas a partir da superfície do eletrodo, devido ao processo de corrosão. Por meio da condutividade da solução, estes dados podem ser convertidos em valores de corrente de corrosão. Logo, um mapa de corrente de corrosão, indiretamente, também é um mapa de potenciais, modificados por uma constante de conversão. Desta forma, considerando a afirmação de Lin et al., o pico na região anódica pode estar relacionado à ocorrência de corrosão por pites no aço carbono.

Reffass et al. [112] estudaram a formação de pites em aço carbono em solução de cloreto e bicarbonato por TEVV, tendo observado que, aproximadamente após $1 \mathrm{~h}$ de imersão em solução, a atividade (que é proporcional à corrente de corrosão) na amostra aumentou, sendo que, para maiores períodos de tempo de imersão houve queda desta atividade. Este resultado mostra um comportamento semelhante ao obtido neste trabalho, pois após $2 \mathrm{~h}$ de 
imersão (Fig. 52b) foi observado um aumento na atividade do metal; mas, a partir de $4 \mathrm{~h}$ de imersão (Fig. 52c) esta atividade diminuiu.

Fushimi et al. [109] utilizaram a técnica de TEVV para estudar a corrosão em aço carbono soldado em água do mar; entretanto, os autores utilizaram metal de enchimento (aço inoxidável 309) diferente do metal base. A fim de estudar todas as regiões da solda, os autores propuseram uma montagem, em que várias partes do aço em diferentes regiões foram cortadas, e todas foram embutidas em resina, formando um arranjo com multi eletrodos. A solda se constituiu como zona catódica, e o metal base, como zona anódica. Os autores observaram também que, de fato, a região adjacente à solda (ZAC) foi a que sofreu maior corrosão que as regiões mais distantes desta. A localização das zonas anódica (metal base) e catódica (solda), contrárias aos resultados experimentais obtidas neste trabalho, é plausível, uma vez que o material usado pelos autores como solda possui composição química mais nobre (aço inoxidável, usado como material de enchimento) que o metal base (aço carbono). Os autores observaram também que, à medida que a camada de óxido se formava sobre o metal base, a corrente de corrosão diminuía, de forma que a diferença entre as correntes anódica e catódica foi maior no estágio inicial. Este comportamento também foi observado pelos resultados aqui apresentados.

Não somente as composições química e estrutural do metal base influenciam seu comportamento frente à corrosão, mas também o ambiente em que este se encontra. Assim, Hemmingsen et al. [113] concluíram que, a diferentes valores de $\mathrm{pH}$, diferentes comportamentos são observados entre as regiões de fusão, ZAC e metal base de um aço carbono. Em outras palavras, a variação do $\mathrm{pH}$ do meio altera a ordem dos potenciais das diferentes zonas, alterando a sequência dos materiais mais e menos nobres. Por isso, em uma análise comparativa é importante considerar a composição química, fase estrutural e meio aquoso ( $\mathrm{pH}$, composição do meio) em que a análise está sendo feita.

Com as análises até aqui apresentadas e discutidas, é possível concluir que a alteração térmica no aço carbono não somente torna a região de solda mais suscetível aos processos de corrosão, mas também, quando o metal base e a solda estão acoplados, um par galvânico é formado (solda como ânodo e metal base como cátodo). Para analisar melhor as correntes anódica e catódica, um gráfico com a densidade de corrente de corrosão ao longo de uma linha do mapa 2D de SVET foi construído e apresentado na Fig. 53, para diferentes tempos de imersão. 


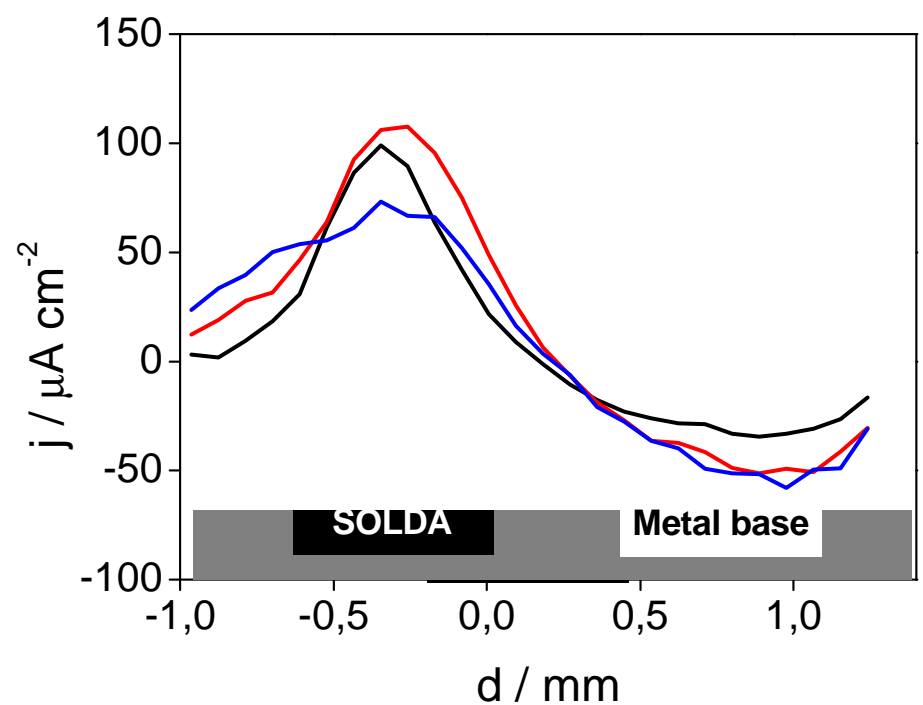

Figura 53 - Análise da densidade de corrente de corrosão de região dos mapas bidimensionais de TEVV (Fig. $50)$.

Os resultados analisados nas linhas de corrente mostram um máximo valor densidade de corrente anódica após $2 \mathrm{~h}$ de imersão (aproximadamente $100 \mu \mathrm{A} \mathrm{cm}^{-2}$ ) e corrente catódica, para este tempo, de aproximadamente $-50 \mu \mathrm{A} \mathrm{cm} \mathrm{cm}^{-2}$. Após $4 \mathrm{~h}$ em solução, a corrente anódica diminuiu para aproximadamente $74 \mu \mathrm{A} \mathrm{cm} \mathrm{c}^{-2}$ enquanto a corrente catódica aumentou discretamente. Após 12 h, a corrente anódica manteve-se aproximadamente a mesma (77 $\mu \mathrm{A}$ $\mathrm{cm}^{-2}$ ), e a corrente catódica diminuiu (para aproximadamente $35 \mu \mathrm{A} \mathrm{cm}{ }^{-2}$ ), indicando que o processo de corrosão pode ter diminuído, atingindo um estado estacionário. A formação da camada de óxido pode diminuir a velocidade de corrosão; entretanto, o processo de corrosão não cessa porque a camada de óxido formada não é aderente. Esta análise demonstra de forma mais clara os resultados anteriormente discutidos.

É possível também unir 3 tipos de análises diferentes em um mesmo gráfico: SVET (mapa 2D), LEIS (varredura por linha) e microscopia óptica (Fig. 54), a fim de comparar qualitativamente estes resultados. 


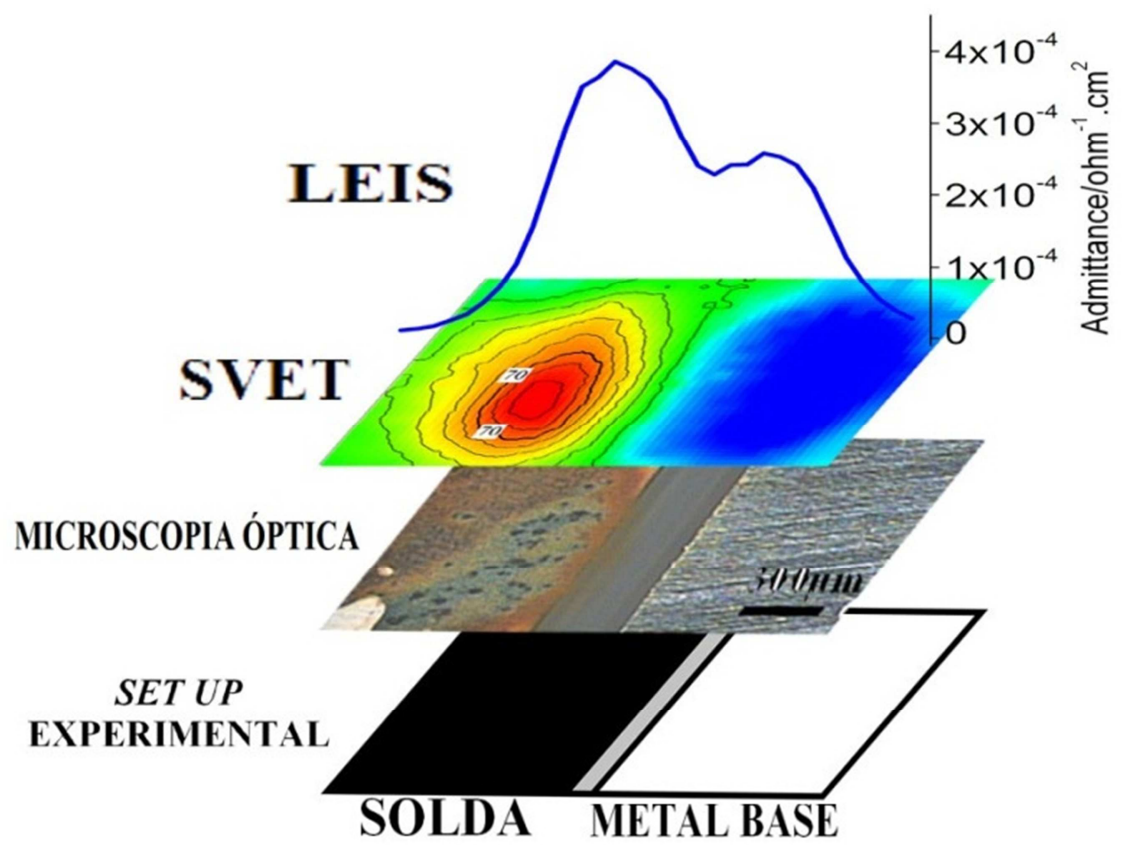

Figura 54 - Análise comparativa por 3 técnicas: EIEL, TEVV e MO, em aço carbono 1020; o arranjo dos eletrodos também foi representado. Análise feita com eletrodos conectados eletricamente, após $2 \mathrm{~h}$ imersos em $\mathrm{NaCl} 0,005 \mathrm{~mol} \mathrm{~L}^{-1}$.

Na Fig. 54 são representados os resultados obtidos após 2 h de imersão em solução de $\mathrm{NaCl}$, pelos quais pode ser observado que as diferentes análises se corroboram. Pela microscopia óptica é observada a formação de óxido somente na região de solda, fato este confirmado por TEVV. Por esta técnica também é mostrado que esta região é anódica com relação ao metal base. Pela análise de EIEL, observa-se que a corrosão (admitância) é mais intensa na região de solda.

É importante destacar que a situação em que se observa formação de produto de corrosão somente na região de solda ocorre quando as duas regiões estão eletricamente conectadas, permitindo a formação de um par galvânico (Fig. 55a-b). Se os eletrodos estão eletricamente desconectados, a camada de óxido é visível em ambos os eletrodos (Fig. 55c-d). Desta forma, todos os resultados apresentados corroboram entre si em mostrar que a região de solda do aço carbono é mais suscetível aos processos de corrosão que o material base, e que a união destes dois promove a formação de um par galvânico. 


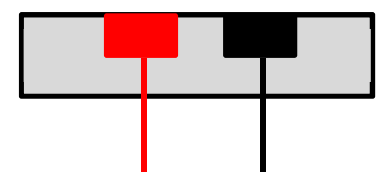

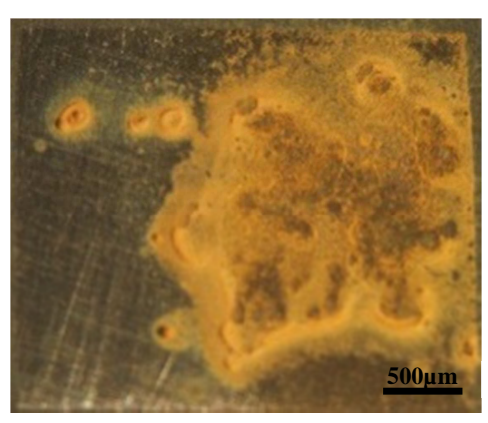

(a)

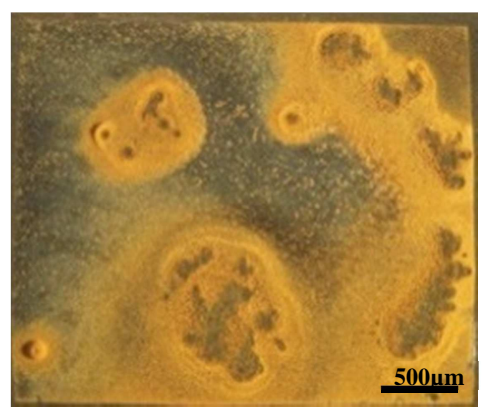

(c)

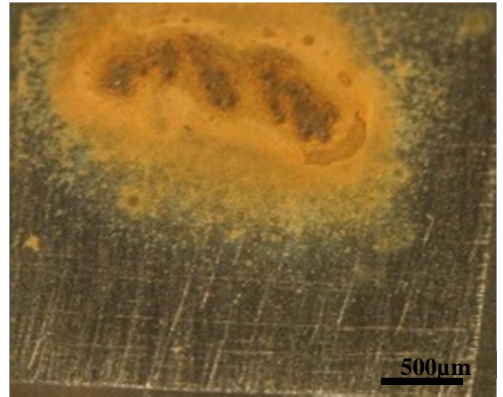

(b)

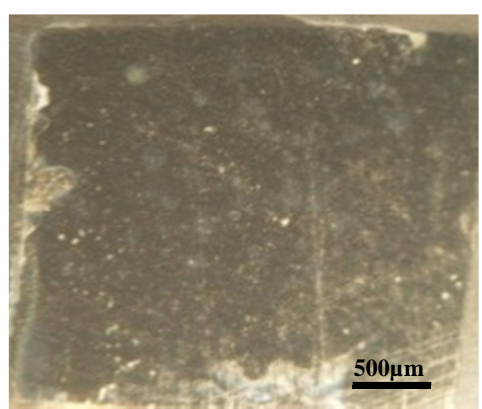

(d)

Figura 55 - Microscopia óptica da solda e metal base do aço carbono 1020 após 24h em NaCl 1,0 mmol L"1. Eletrodos desconectados: (a) solda e (b) metal base; eletrodos conectados eletricamente: (c) solda e (d) metal base.

\subsubsection{Considerações parciais}

O comportamento eletroquímico de aço carbono 1020, com a presença de uma região termicamente afetada por processo de solda, foi estudado em solução de cloreto usando técnicas eletroquímicas globais e localizadas. Os resultados eletroquímicos corroboraram entre si, e mostraram que a solda e o metal base formam um par galvânico, em que a solda é o ânodo e o metal base é o cátodo. Medidas clássicas de corrosão (potencial de circuito aberto e EIE) mostraram que a solda é menos nobre que o metal base, devido a seu potencial de corrosão mais anódico que o metal base, sendo que a região de solda apresentou menor resistência à polarização. As análises localizadas de corrosão foram feitas em regiões específicas do eletrodo, e os resultados foram apresentados como mapas ou linhas da superfície, em completa concordância com as análises globais clássicas. A varredura por linhas da superfície por EIEL resultou em maiores valores de admitância na solda, tanto para o eletrodo individual, como conectado eletricamente. Os dados de TEVV foram obtidos simultaneamente com aquisição de imagens de microscopia óptica e os resultados mostraram a formação de um par galvânico entre a solda e o metal base (solda como ânodo e metal base como cátodo). Os produtos de corrosão formados (óxidos e hidróxidos de ferro) foram 
observados somente na solda quando os eletrodos estavam eletricamente conectados. $\mathrm{Na}$ situação dos eletrodos desconectados, os produtos de corrosão foram observados em ambos os eletrodos.

\subsection{Síntese, caracterização e aplicação de $\mathrm{PAni} \mathrm{TiO}_{2}$ como revestimento protetor contra a corrosão do aço carbono 1020 em meio de cloreto}

Devido à alta suscetibilidade do aço carbono 1020 à corrosão, um revestimento protetor é necessário para que este processo seja inibido. Neste capítulo serão apresentados os resultados da síntese e caracterização de $\mathrm{PAni}$ e compósitos de $\mathrm{PAni} / \mathrm{n}-\mathrm{TiO}_{2}$, à diferentes temperaturas $\left(0\right.$ e $\left.25^{\circ} \mathrm{C}\right)$. Estes materiais serão aplicados como revestimento protetor contra a corrosão do aço carbono 1020, e suas eficiências na proteção contra a corrosão serão testadas por meio de ensaios eletroquímicos e de corrosão acelerada. Ao final, o revestimento com melhores propriedades será utilizado aplicado também em solda do aço carbono 1020, e seu desempenho será avaliado por medidas de corrosão localizada.

\subsubsection{Estudos preliminares de revestimentos a base de PAni e PAni/TiO}

Esses estudos foram iniciados com experimentos para determinar as condições de otimização da síntese do compósito de PAni e nanotubos de $\mathrm{TiO}_{2}\left(\mathrm{PAni} / \mathrm{n}-\mathrm{TiO}_{2}\right)$, bem como testar a eficiência desses na proteção contra a corrosão do aço 1020, comparando-o com o polímero sem n- $\mathrm{TiO}_{2}$. Vários trabalhos citam diferentes formas de deposição da PAni sobre aços, tanto química como eletroquímica mas, para a deposição do $\mathrm{TiO}_{2}$ sobre aço o que é encontrado na literatura são métodos de deposição sol-gel (somente com substratos de aços inoxidáveis) [114,115], por plasma (sputtering) [116-120], e ainda deposição química ativada por micro-ondas [121]. Para o aço carbono, uma menor quantidade de métodos de deposição é encontrada e, em geral, a deposição é feita por sputtering de partículas de $\mathrm{Al}_{2} \mathrm{O}_{3}$ ou, menos comum, $\mathrm{Fe}_{2} \mathrm{O}_{3}$, juntamente com uma menor proporção de $\mathrm{TiO}_{2}$, apenas para que características como menor porosidade e aumento da resistência à corrosão sejam conseguidas [122-127].

Assim, combinando os métodos de deposição da PAni e do $\mathrm{TiO}_{2}$ que são comumente encontrados na literatura, o método utilizado foi o de síntese química da PAni em presença de $\mathrm{TiO}_{2}$, e deposição química do compósito por meio do uso de um solvente e secagem sob temperatura controlada. 
Radhakrishnan et al. [70] realizaram a síntese química da $\mathrm{PAni}$ com $\mathrm{TiO}_{2}$ e o aplicaram sobre aço carbono. No presente trabalho, utilizando as condições descritas na referência 68, as sínteses foram feitas em meio de $\mathrm{HCl} 1,0 \mathrm{~mol} \mathrm{~L}^{-1}$, utilizando $0,058 \mathrm{~mol} \mathrm{~L}^{-1}$ de anilina e igual concentração de $\left(\mathrm{NH}_{4}\right)_{2} \mathrm{~S}_{2} \mathrm{O}_{8}$. Uma quantidade de $0,5 \mathrm{~g}$ de n- $\mathrm{TiO}_{2}$ foi utilizada, e a síntese foi conduzida a 0 e $25^{\circ} \mathrm{C}$, sob constante agitação, por $4 \mathrm{~h}$. Os polímeros foram usados na forma de sal esmeraldina (utilizados logo após a síntese e secagem do polímero), e base esmeraldina (obtido a partir da desdopagem do sal esmeraldina em solução de $\mathrm{NH}_{4} \mathrm{OH}$ ). Ambos foram depositados utilizando um mesmo solvente, a partir de sua dissolução (para a base esmeraldina) ou suspensão (para o sal esmeraldina) em n-metil-2-pirrolidona (NMP), e secagem em estufa a cerca de $60{ }^{\circ} \mathrm{C}$ por $12 \mathrm{~h}$. Após aplicação dos filmes, as amostras foram submetidas a ensaios de polarização potenciodinâmica, utilizando o SPC.

A morfologia dos filmes dopados após os ensaios a partir de polímero dopado (Fig. 56) apresentaram um aspecto heterogêneo, com presença de rachaduras (Fig. 56(c e d)). A morfologia resultante do filme sintetizado à menor temperatura (Fig. 56c) apresentou maior continuidade do que aquele sintetizado à maior temperatura (Fig. 56d). Contudo, em nenhuma das duas amostras é observada uma grande resistência à corrosão, já que fraturas expuseram a superfície do aço aos íons $\mathrm{Cl}^{-}$.

Shen et al. [114] utilizaram o método sol-gel para produzir um filme de $\mathrm{TiO}_{2}$ sobre aço inox 316L. Eles também observaram fraturas nos filmes de $\mathrm{TiO}_{2}$, as quais foram atribuídas ao tratamento térmico. As rachaduras eram formadas durante a etapa de evaporação do solvente, induzindo à deformação do filme nas regiões próximas à borda. Como fator intensificador destas rachaduras, as amostras foram repetidamente submetidas a este tratamento térmico, pois um sistema multicamadas foi aplicado pelos autores, o que evidenciou ainda mais este efeito e sua causa. Entretanto, nos resultados apresentados as temperaturas não são tão altas como no trabalho anteriormente citado. Por isso, as rachaduras observadas nas figuras 56c e $56 \mathrm{~d}$ provavelmente estão associadas às tensões causadas no polímero na deposição de mais de uma camada.

Shen et al. [115] também observaram que o óxido possui uma ótima característica de proteção à corrosão (proteção anódica). Nos resultados obtidos, as curvas de polarização potenciodinâmica dos polímeros dopados estão apresentadas na figura 58a; em primeira análise, os parâmetros eletroquímicos (Tabela 11) mostram que houve um aumento da corrente de corrosão nas amostras com $\mathrm{PAni} / \mathrm{TiO}_{2}$, com relação ao metal sem recobrimento. 


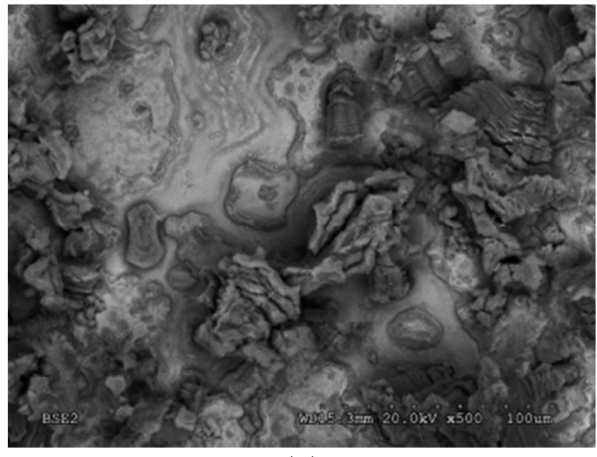

(a)

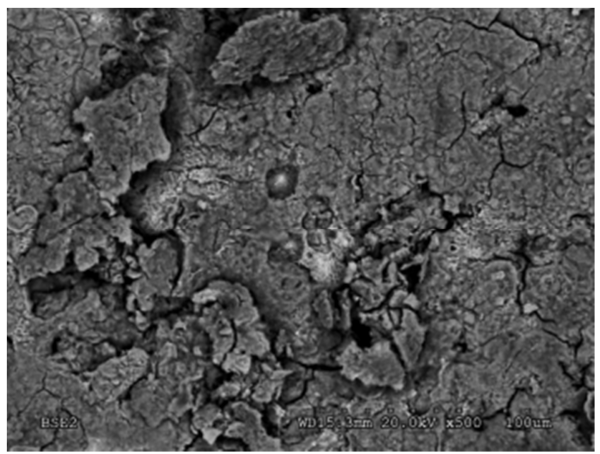

(c)

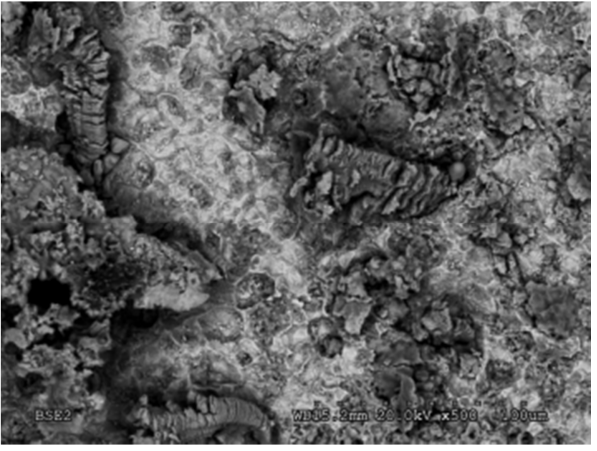

(b)

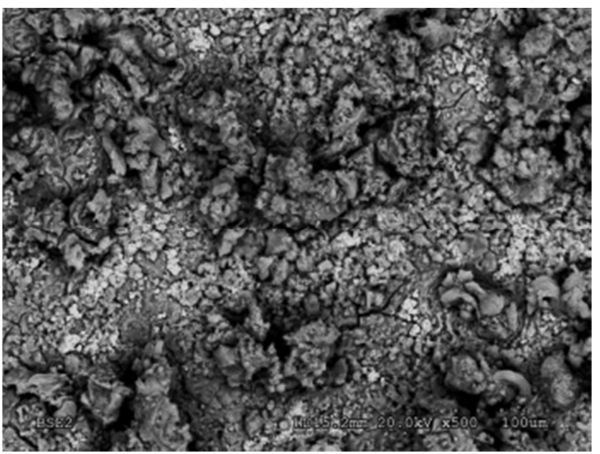

(d)

Figura 56 - MEV de aço carbono com recobrimentos dopados, após polarização anódica (utilizando o SPC) em $\mathrm{NaCl} 3,0 \%$. (a) PAni $0^{\circ} \mathrm{C}$, (b) PAni $25^{\circ} \mathrm{C}$, (c) $\mathrm{PAni} / \mathrm{TiO}_{2} 0^{\circ} \mathrm{C}$ e (d) $\mathrm{PAni} / \mathrm{TiO}_{2} 25^{\circ} \mathrm{C}$.

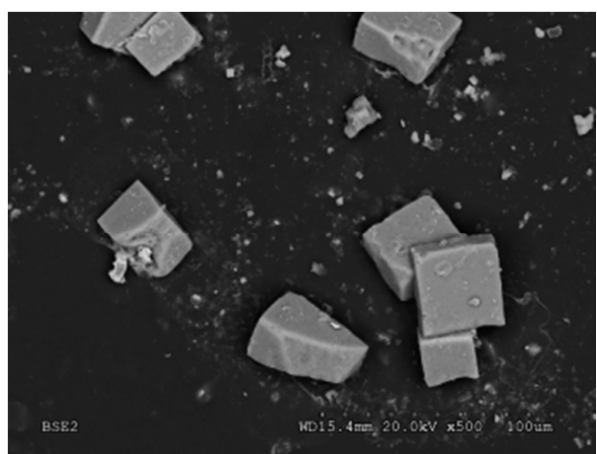

(a)

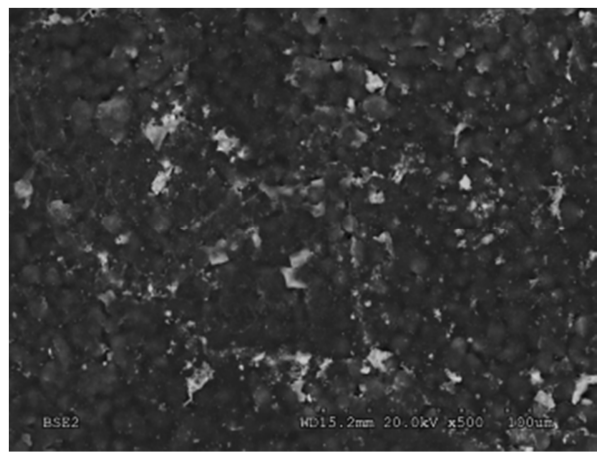

(c)

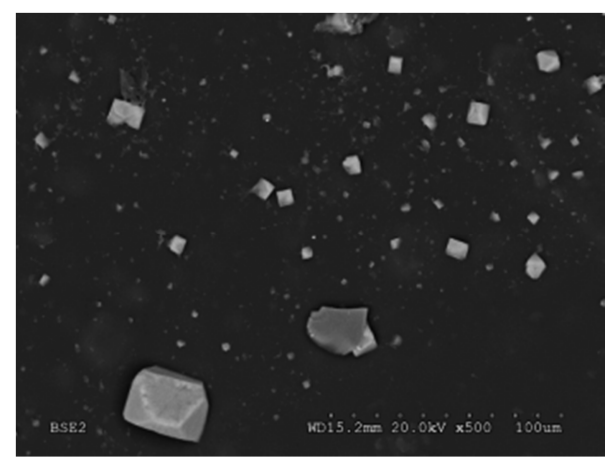

(b)

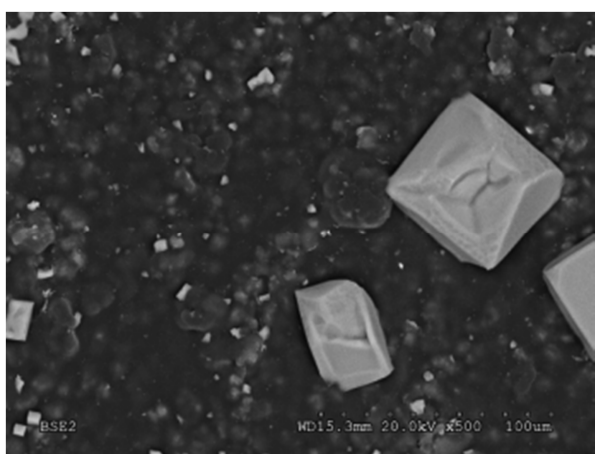

(d)

Figura 57 - MEV de aço carbono com recobrimentos desdopados, após polarização anódica (utilizando o SPC) em $\mathrm{NaCl} 3,0 \%$. (a) PAni $0^{\circ} \mathrm{C}$, (b) PAni $25^{\circ} \mathrm{C}$, (c) $\mathrm{PAni} / \mathrm{TiO}_{2} 0^{\circ} \mathrm{C}$ e (d) $\mathrm{PAni} / \mathrm{TiO}_{2} 25^{\circ} \mathrm{C}$. 


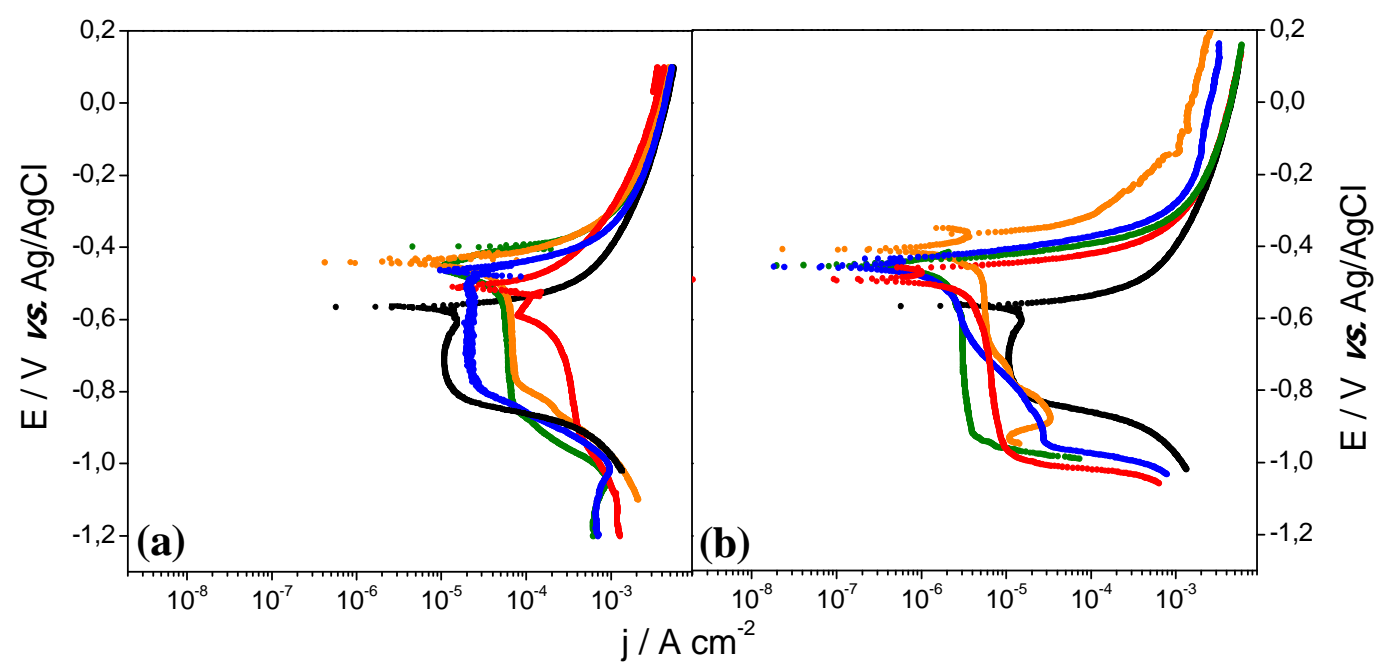

Figura 58 - Curvas de polarização potenciodinâmica catódica e anódica em solução de $\mathrm{NaCl}$ 3,0\% (utilizando o SPC) de aços carbono com recobrimentos (a) dopados e (b) desdopados. • Aço carbono sem recobrimento; • PAni $0^{\circ} \mathrm{C}$; $\bullet$ PAni $25^{\circ} \mathrm{C}$; $\bullet$ PAni/n- $-\mathrm{TiO}_{2} 0^{\circ} \mathrm{C}$; $\bullet \mathrm{PAni} / \mathrm{n}-\mathrm{TiO}_{2} 25^{\circ} \mathrm{C}$.

Tabela 11 - Parâmetros eletroquímicos obtidos nas análises das curvas de polarização (utilizando o SPC) de aço carbono 1020 com diferentes recobrimentos (Fig. 58)

\begin{tabular}{|c|c|c|c|c|}
\hline \multicolumn{3}{|c|}{$\mathrm{E}_{\text {corr }} / \mathbf{V} v \mathbf{}$ s. $\mathrm{Ag} / \mathrm{AgCl}$} & $\mathbf{j}_{\mathrm{corr}} / \mu \mathrm{A} \mathbf{c m}^{-2}$ & \\
\hline \multicolumn{2}{|c|}{ Aço carbono } & $-0,564$ & 46,5 & \\
\hline & \multicolumn{2}{|c|}{ Amostras dopadas } & \multicolumn{2}{|c|}{ Amostras desdopadas } \\
\hline & $\mathrm{E}_{\text {corr }} / \mathrm{V} v s . \mathrm{Ag} / \mathrm{AgCl}$ & $\mathbf{j}_{\text {corr }} / \mu \mathrm{A} \mathbf{c m}^{-2}$ & $\mathrm{E}_{\text {corr }} / \mathrm{V}$ vs. Ag/AgCl & $\mathrm{j}_{\mathrm{corr}} / \mu \mathrm{A} \mathrm{cm}$ \\
\hline PAni $0^{\circ} \mathrm{C}$ & $-0,509$ & 112 & $-0,459$ & 58,3 \\
\hline PAni $25^{\circ} \mathrm{C}$ & $-0,463$ & 90,7 & $-0,455$ & 6,42 \\
\hline $\mathrm{PAni} / \mathrm{TiO}_{2} 0^{\circ} \mathrm{C}$ & $-0,397$ & 267 & $-0,452$ & 3,76 \\
\hline PAni/TiO ${ }_{2} 25^{\circ} \mathrm{C}$ & $-0,441$ & 147 & $-0,363$ & 7,67 \\
\hline
\end{tabular}

As imagens de MEV da Fig. 56 (a, b) mostram a superfície do aço nas amostras que contêm somente PAni. Como o polímero está dopado, ao aplicar-se um potencial, a corrente resultante será a somatória de duas componentes: a oxidação do substrato e a oxidação do polímero. Por isso, para o caso dos polímeros dopados, se observam maiores correntes de corrosão (Tabela 11, Fig. 58a) [128].

Análises de polarização potenciodinâmica foram feitas também para a PAni desdopada (Fig. 58b). As imagens de MEV após esta análise (Fig. 57) mostram, de forma geral, filmes mais homogêneos e sem descontinuidades ou rachaduras. Os cubos brancos observados nas 
micrografias dos filmes desdopados são cristais de $\mathrm{NaCl}$, que foram deixados sobre a amostra para localizar as regiões de análise, já que estas foram feitas em uma área pequena (com o SPC). Como não houve degradação do filme ou regiões deste que evidenciassem o ataque, os cristais de $\mathrm{NaCl}$ não foram removidos por lavagem após a análise para possibilitar a identificação da região analisada.

As amostras de PAni com n- $\mathrm{TiO}_{2}$ (Fig. 57 (c, d)) apresentam pontos esbranquiçados distribuídos pela matriz polimérica, referentes ao $\mathrm{n}-\mathrm{TiO}_{2}$. Os resultados eletroquímicos (Tabela 11) obtidos pela análise das curvas de polarização potenciodinâmica (Fig. 58b) mostram que houve uma diminuição da corrente de corrosão em cerca de uma ordem de grandeza, exceto para a PAni sintetizada a $0{ }^{\circ} \mathrm{C}$. Este deslocamento ocorreu pelo caráter isolante do polímero, e pela camada formada, sobre a qual não se vê defeitos como rachaduras ou pontos de descontinuidade. Os valores de $\mathrm{E}_{\text {corr }}$ apresentaram deslocamento catódico, sendo o maior deles obtido para a $\mathrm{PAni} / \mathrm{n}-\mathrm{TiO}_{2} 25^{\circ} \mathrm{C}$. Já efeitos de difusão do $\mathrm{Fe}$ no $\mathrm{TiO}_{2}$ provavelmente não ocorreram, pois para isso altas temperaturas (da ordem de $700^{\circ} \mathrm{C}$ ) seriam necessárias [121].

Baixas correntes de corrosão são muito desejáveis no caso do aço carbono, pois o óxido formado não é passivador, como nos aços inoxidáveis. Assim, é importante impedir ao máximo que haja contato entre a solução de análise e a superfície do metal. Pelos resultados obtidos, PAni na forma base esmeraldina (desdopada) foi a que agregou os melhores resultados para os objetivos desejados, e, por isso foi utilizada para estudos posteriores.

\subsubsection{Síntese e caracterização da PAni/n- $\mathrm{TiO}_{2}$ em meio de $\mathrm{H}_{2} \mathrm{SO}_{4}$}

O compósito PAni/n- $\mathrm{TiO}_{2}$ foi sintetizado alterando o meio de síntese para $\mathrm{H}_{2} \mathrm{SO}_{4}$. Foram utilizadas concentrações de anilina e de $\left(\mathrm{NH}_{4}\right)_{2} \mathrm{~S}_{2} \mathrm{O}_{8}$ de 0,1 mol L ${ }^{-1}$ cada, em meio de $\mathrm{H}_{2} \mathrm{SO}_{4} 0,5 \mathrm{~mol} \mathrm{~L}{ }^{-1}$, contendo $0,5 \mathrm{~g}$ de $\mathrm{TiO}_{2}$. Os perfis de potencial e de temperatura em função do tempo de síntese foram acompanhados e estão apresentados na Fig. 59. 


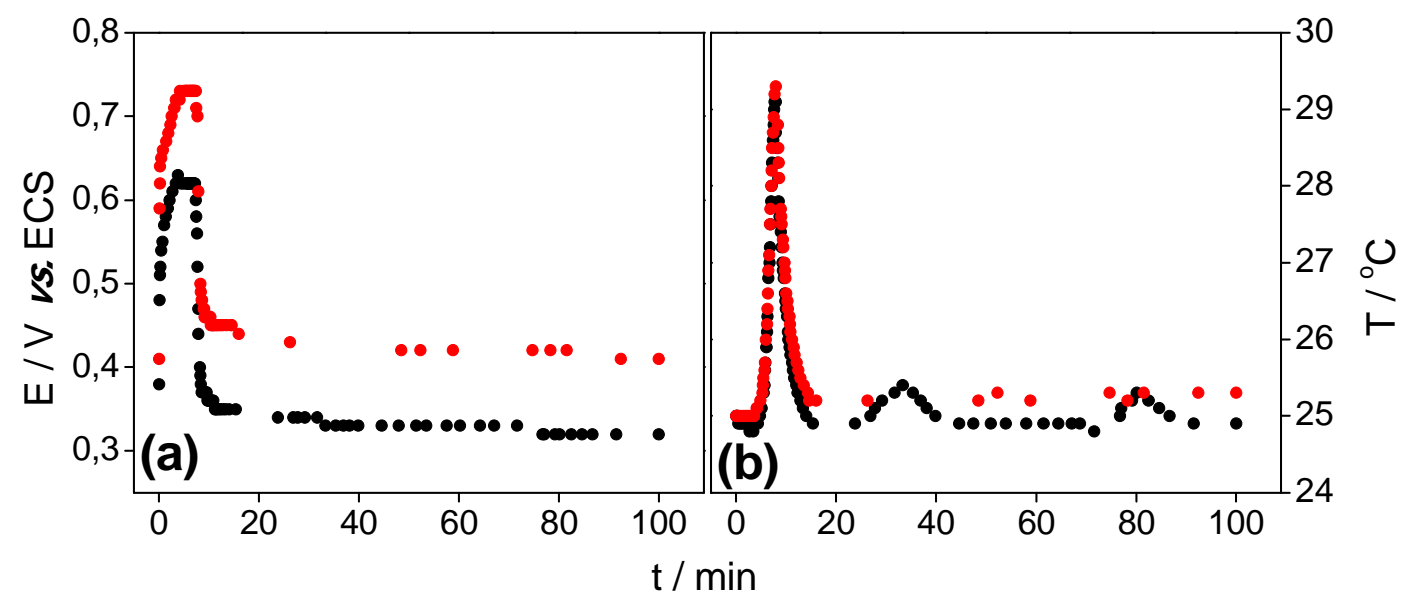

Figura 59 - Perfil de (a) potencial e (b) temperatura durante a síntese em meio de $\mathrm{H}_{2} \mathrm{SO}_{4}$ de: $(\bullet)$ PAni e (•) $\mathrm{PAni} / \mathrm{n}-\mathrm{TiO}_{2}$.

De forma geral, a síntese química da PAni envolve 3 etapas. A primeira, chamada etapa de indução, inicia-se imediatamente após a adição do agente oxidante, quando os primeiros oligômeros começam a polimerizar-se; este estágio é caracterizado por um aumento no potencial. O segundo estágio é a etapa de propagação, em que o potencial atinge um valor máximo e um aumento na temperatura da reação é observado. O terceiro estágio, chamado de terminação, se caracteriza por uma diminuição do potencial, que após atingir um determinado valor, permanece constante com o tempo $[129,130]$. Há uma etapa exotérmica no último estágio, mas o aumento de temperatura é muito menor que no segundo (este aumento de temperatura frequentemente não é detectável a menos que o sensor de temperatura seja de grande sensibilidade).

A evolução do potencial de circuito aberto da síntese da PAni e PAni/n- $\mathrm{TiO}_{2}$ a $25{ }^{\circ} \mathrm{C}$ (Fig. 59) apresenta as 3 etapas mencionadas. Na síntese de $\mathrm{PAni} / \mathrm{n}-\mathrm{TiO}_{2}$ observa-se um maior valor de potencial durante a etapa de propagação. Este valor pode estar associado à presença do $\mathrm{n}-\mathrm{TiO}_{2}$, que pode ter se comportado como núcleos para a polimerização dos monômeros de anilina, resultando em um material final mais estável e compacto que a PAni. Confirmando esta justificativa, o potencial final da $\mathrm{PAni} / \mathrm{n}-\mathrm{TiO}_{2}$ (após estabilização) foi maior do que para a PAni. A evolução da temperatura com o tempo (Fig. 59b) mostra o comportamento termodinâmico descrito anteriormente, porém não se observa nenhuma diferença significativa entre as duas amostras. Este perfil indica que o $\mathrm{n}-\mathrm{TiO}_{2}$ não contribui termodinamicamente para a reação e somente age como pontos de nucleação para a polimerização. 


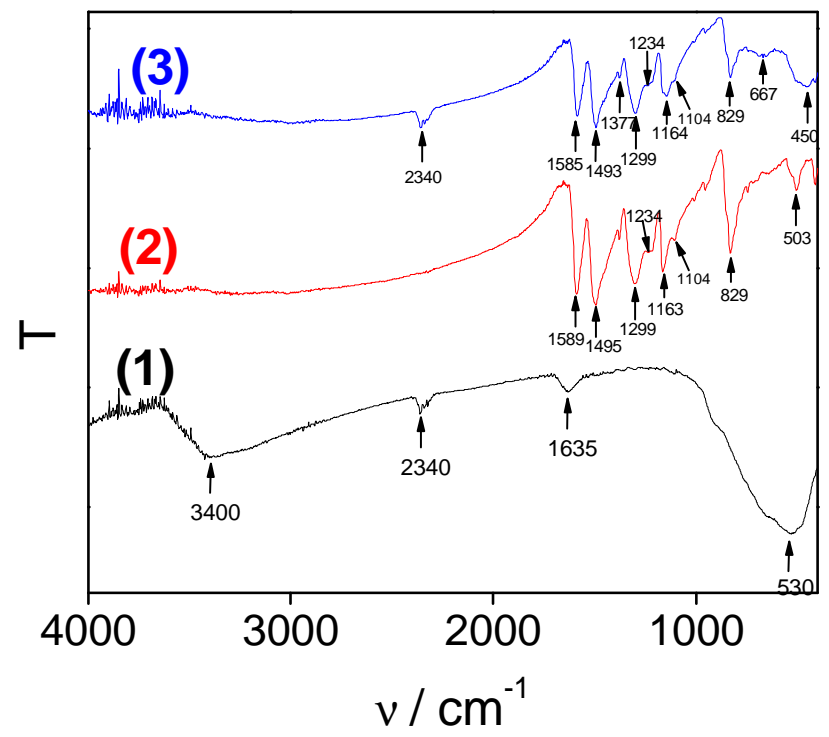

Figura 60 - Espectros de absorção molecular na região do IV: (1) n- $\mathrm{TiO}_{2}$, (2) PAni e (3) PAni/n-TiO.

Tabela 12 - Bandas características do n- $\mathrm{TiO}_{2}$, PAni e PAni/n- $\mathrm{TiO}_{2}$ na análise por espectroscopia IV (Fig. 58)

\begin{tabular}{|lcccc|}
\hline \multicolumn{1}{|c}{ Tipo de Vibração } & n-TiO & & PAni & PAni/n-TiO \\
\hline C- H fora do plano & x & 829 & 829 \\
C-N-C aromático & x & 1163 & 1142 \\
Vibração C- H fora do plano & x & 503 & 450 \\
\hline Alongamento C=N de grupo quinoide & x & 1589 & 1585 \\
Alongamento C=C de grupo benzenóide & x & 1495 & 1493 \\
\hline Alongamento C-N de grupo benzenóide & x & 1299 e 1234 & 1299 e 1238 \\
\hline Vibração C- H H H no plano & x & 1104 & 1104 \\
\hline Vibração Ti-O-Ti antissimétrico & 530 & X & X \\
\hline Alongamento C=N e C=C de grupo benzenóide & x & 1495 & 1493 \\
\hline Alongamento C=N e C=C de grupo quinóide & x & 1589 & 1585 \\
\hline
\end{tabular}

Evolução de temperatura semelhante à descrita foi também observada em outro trabalho envolvendo o compósito $\mathrm{PAni} / \mathrm{n}-\mathrm{TiO}_{2}$ em solução aquosa de $\mathrm{HCl}$ [72]. Análises realizadas com espectroscopia de absorção FTIR foram feitas para o n-TiO 2 , PAni e PAni/n- $\mathrm{TiO}_{2}$ (Fig. 60) e a descrição dos números de onda mais importantes estão listadas na Tabela 12. O perfil obtido para o n- $\mathrm{TiO}_{2}$ é similar a outros espectros encontrados em trabalhos na literatura para 
$\mathrm{TiO}_{2}$ nano estruturado, em que os picos a 3.400, 1.635 e $530 \mathrm{~cm}^{-1}$ também foram observados [131-135].

Algumas bandas do espectro de $\mathrm{PAni} / \mathrm{n}-\mathrm{TiO}_{2}$ sofreram deslocamento com relação aos correspondentes no espectro de PAni, como as bandas a 450 e $503 \mathrm{~cm}^{-1}$ (a banda a $2.340 \mathrm{~cm}^{-1}$ é atribuída ao $\mathrm{CO}_{2}$ do ar). A banda a $503 \mathrm{~cm}^{-1}$ corresponde à vibração $\mathrm{C}$ - $\mathrm{H}$ fora do plano no espectro de PAni. No espectro de PAni/n- $-\mathrm{TiO}_{2}$ esta banda foi alargada e assume um novo valor de $450 \mathrm{~cm}^{-1}$. Este efeito, assim como outros deslocamentos, podem ser atribuídos ao efeito do n- $\mathrm{TiO}_{2}$ sobre a $\mathrm{PAni}$. Bandas da partícula de $\mathrm{n}-\mathrm{TiO}_{2}$ não podem ser claramente vistas porque o polímero recobre os nanotubos, e esconde o sinal do óxido devido à estrutura tipo casca-caroço. A forte absorção na região de $667 \mathrm{~cm}^{-1}$ pode ser observada no espectro de $\mathrm{n}-\mathrm{TiO}_{2}$. Esta banda é fraca no espectro da $\mathrm{PAni} / \mathrm{n}-\mathrm{TiO}_{2}$ porque a PAni recobre os nanotubos. Ainda, o Ti tem tendência de formar complexos com nitrogênio, limitando assim os modos de vibração da PAni, o que justifica os deslocamentos de bandas [69,136-141].

Uma análise qualitativa por espectroscopia de absorção na região do UV-vis foi feita para caracterizar a PAni. A análise foi feita a partir do polímero desdopado, o qual é solúvel em NMP. Após esta primeira análise, uma pequena quantidade de $\mathrm{HCl}$ diluído foi adicionada à cubeta com a solução para dopar o polímero e, neste estado de dopagem, uma nova análise foi feita. Como as análises foram feitas a partir de solução de polímero dissolvido em NMP, não foi possível analisar o polímero com n- $\mathrm{TiO}_{2}$, já que este formaria uma suspensão em solução. Assim, a preparação das amostras de $\mathrm{PAni} / \mathrm{n}-\mathrm{TiO}_{2}$ envolveu a dissolução do material em NMP e posterior filtração, etapa em que o $\mathrm{n}-\mathrm{TiO}_{2}$ ficou retido no papel de filtro (partículas em suspensão causam espalhamento neste tipo de análise e, consequentemente, resultados errôneos). Assim, os resultados para $\mathrm{PAni} / \mathrm{n}-\mathrm{TiO}_{2}$ refletem somente se o óxido causou algum deslocamento da banda do polímero.

No polímero desdopado (Fig. 61b) são observadas duas bandas de absorção, uma a 327 nm, correspondente à transição $\pi-\pi^{*}$ dos anéis benzenóides e outra, a $635 \mathrm{~nm}$, correspondente à transição de cargas entre anéis quinóide e benzenóide. No polímero dopado (Fig. 61a) há uma nova banda a $428 \mathrm{~nm}$, atribuída aos radicais cátions que se formam no processo de dopagem. A banda alargada a $837 \mathrm{~nm}$ está associada aos transportadores de carga da cadeia polimérica (banda excitônica) [85,142,143]. Não houve deslocamento apreciável nos comprimentos de onda de absorção entre os polímeros sintetizados na presença e ausência do $\mathrm{n}-\mathrm{TiO}_{2}$, e tampouco em diferentes temperaturas. Isto mostra que o n- $\mathrm{TiO}_{2}$ não alterou a natureza das ligações natureza das cadeias poliméricas. Além disso, estes resultados comprovam que de fato foi obtida polianilina das sínteses. 


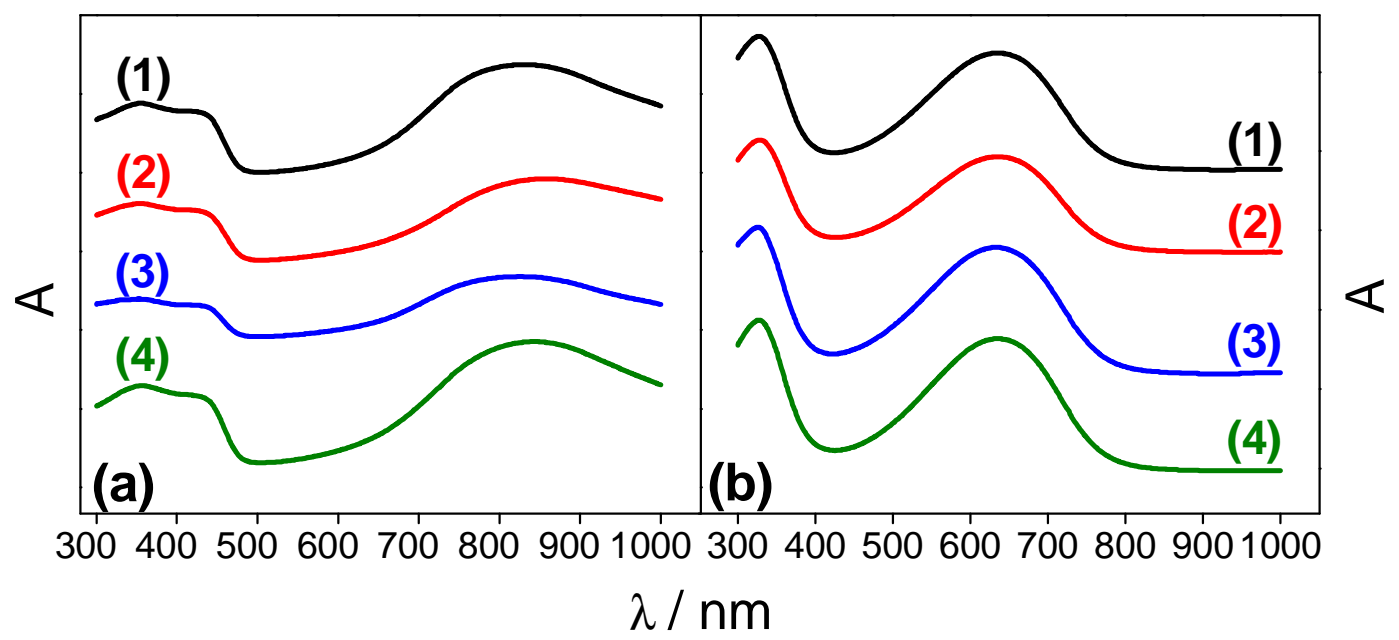

Figura 61 - Espectros de absorção UV-vis dos polímeros em NMP, nos estados (a) dopado e (b) desdopado. PAni a: (1) 0 e (2) $25^{\circ} \mathrm{C}$; $\mathrm{PAni} / \mathrm{TiO}_{2}$ a: (3) $0^{\circ} \mathrm{C}$ e (4) $25^{\circ} \mathrm{C}$.
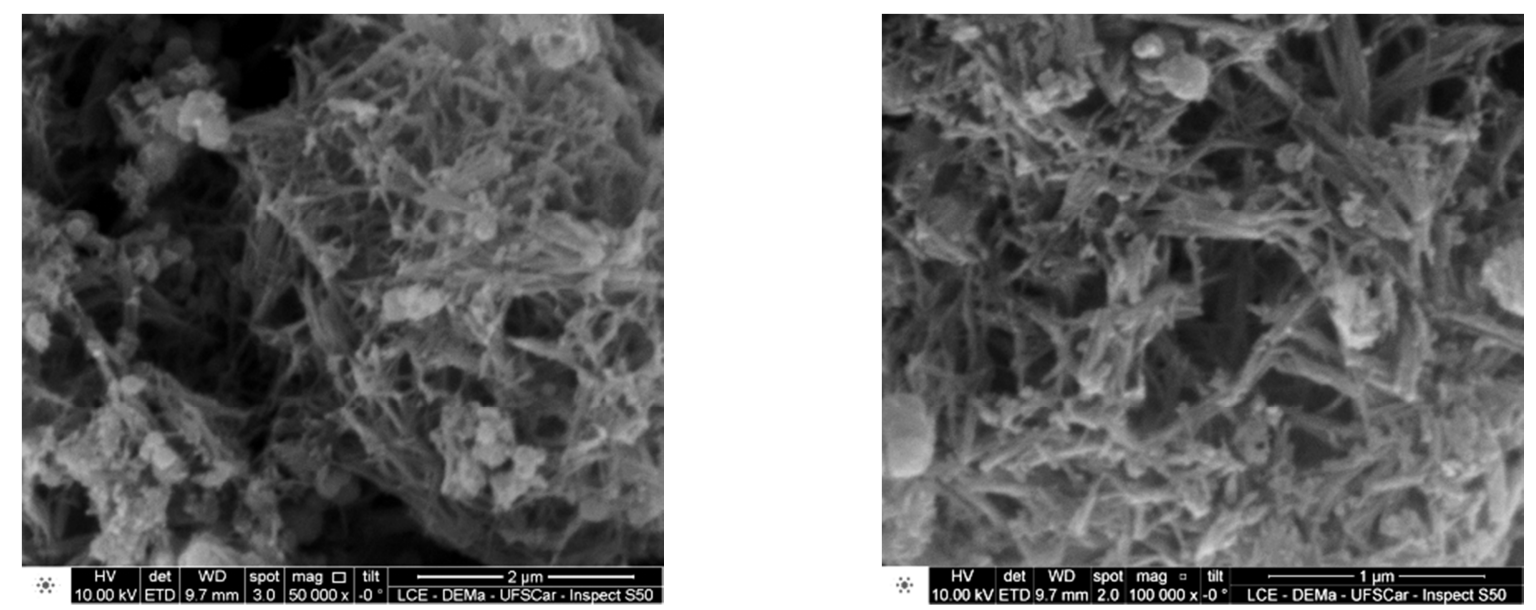

Figura 62 - Análise do n-TiO 2 por MEV com fonte de ionização de campo (FEG).

A natureza manométrica do $\mathrm{n}-\mathrm{TiO}_{2}$ foi confirmada pelo espectro de absorção FTIR. Para confirmar sua morfologia (nanotubos), uma análise de MEV utilizando fonte de campo (FEG - Field Emission Gun, para maior resolução) foi feita (Fig. 62). Pela referida análise, se observam os nanotubos na estrutura.

A morfologia dos polímeros pôde ser analisada por microscopia eletrônica de varredura; as imagens apresentadas foram obtidas utilizando detector de elétrons secundários. Os polímeros dopados (Fig. 63), embora não tenham sido utilizados como revestimentos, também foram analisados para observar sua morfologia após a síntese, e as possíveis alterações decorrentes do processo de desdopagem. 


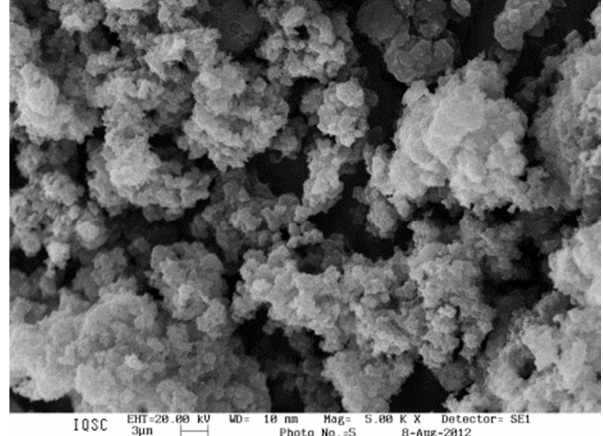

(a)

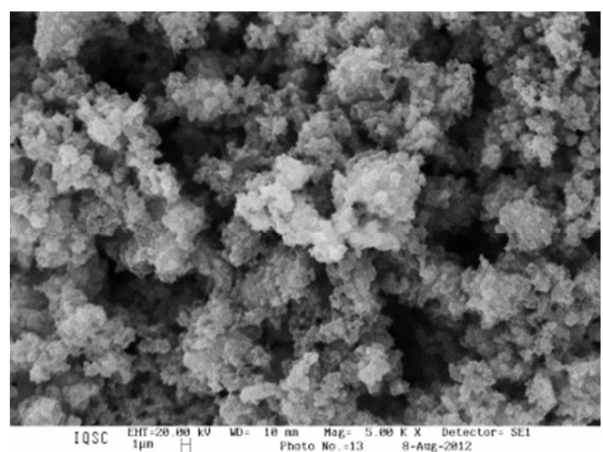

(c)

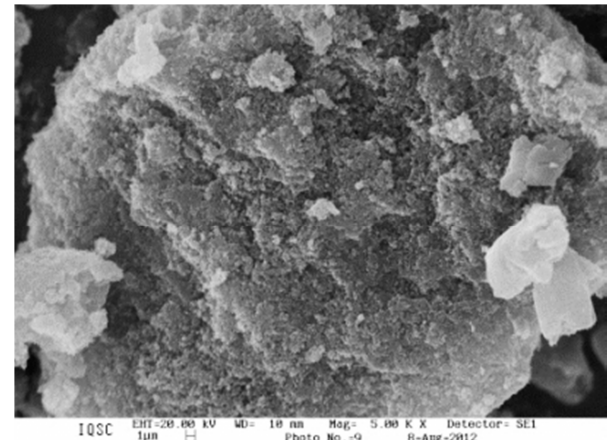

(b)

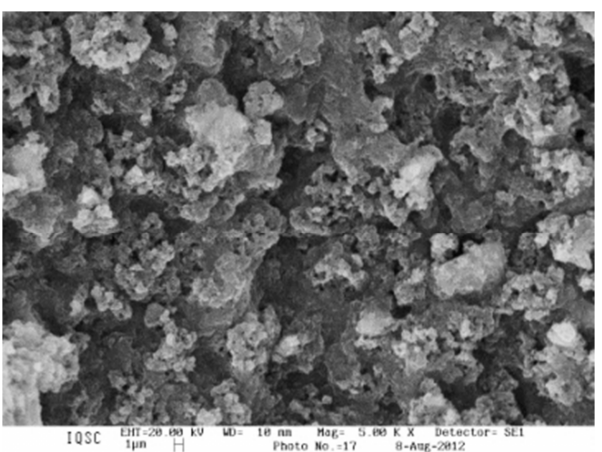

(d)

Figura 63 - MEV dos polímeros e compósitos dopados (em pó). PAni sintetizada a: (a) 0 e (b) $25^{\circ} \mathrm{C} ;$ PAni/n$\mathrm{TiO}_{2}$ sintetizado a: (c) 0 e (d) $25^{\circ} \mathrm{C}$.

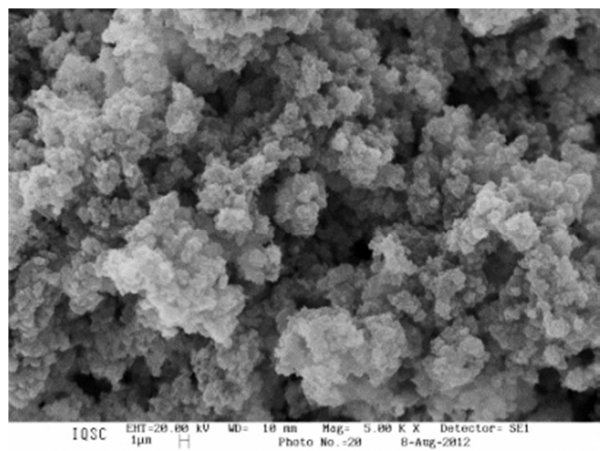

(a)

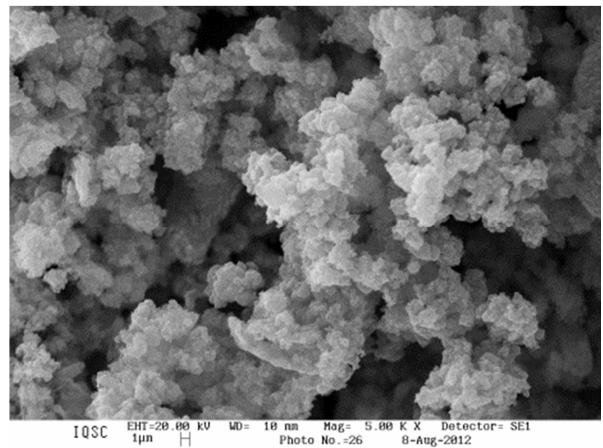

(c)

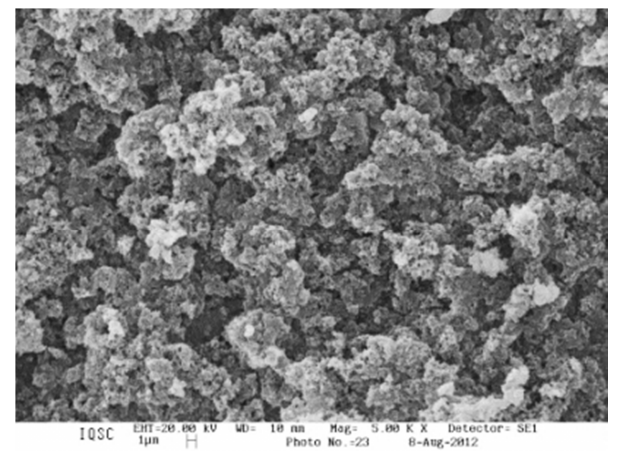

(b)

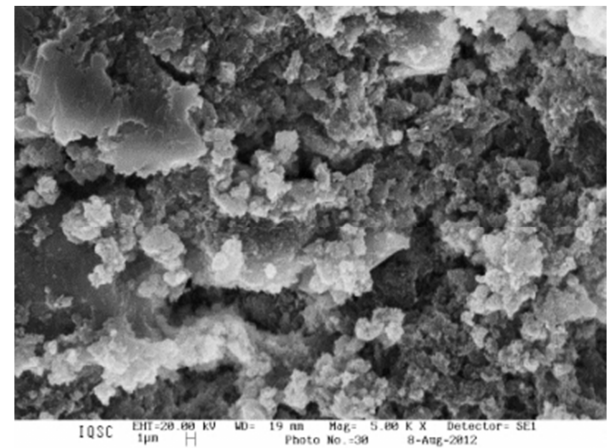

(d)

Figura 64 - MEV dos polímeros e compósitos desdopados (em pó). PAni sintetizada a: (a) 0 e (b) $25^{\circ} \mathrm{C}$; PAni/n$\mathrm{TiO}_{2}$ sintetizado a: (c) 0 e (d) $25^{\circ} \mathrm{C}$. 
Nas imagens de MEV referentes ao polímero dopado (Fig. 63), a menor temperatura de síntese resultou em partículas menores do polímero enquanto que, a maior temperatura de síntese resultou em um polímero menos disperso, semelhante a placas. Esta mesma morfologia foi observada nos polímeros com n- $\mathrm{TiO}_{2}$; esta observação também se aplica nos polímeros desdopados (Fig. 64). Destas imagens pode-se afirmar que a temperatura de síntese possui grande influência na morfologia do polímero.

Pawar et al. [144] observaram mudança na morfologia do polímero ao dopar o compósito $\mathrm{PAni} / \mathrm{TiO}_{2}$ com ácido canforsulfônico. O compósito $\mathrm{PAni} / \mathrm{TiO}_{2}$ obtido pelos autores apresentou similaridade com os resultados aqui observados, como a presença de porosidade e de uma estrutura fibrilar, não contínua. Ao dopar o polímero com o ácido orgânico, este passou a apresentar uma estrutura contínua, semelhante à observada aqui para os polímeros sintetizados a $25^{\circ} \mathrm{C}$, com aparecimento de nanobarras (para maiores proporções de ácido). Um dado importante para estabelecer comparações é a temperatura de síntese utilizada por estes autores, no entanto este dado não consta no artigo.

Ganesan et al. [145] também não citam a que temperatura sintetizaram o compósito $\mathrm{PAni} / \mathrm{n}-\mathrm{TiO}_{2}$, porém as imagens de $\mathrm{MEV}$ apresentadas pelos autores possuem uma morfologia muito semelhante à obtida neste trabalho para os polímeros sintetizados a $0{ }^{\circ} \mathrm{C}$, de um material esférico e poroso. Savitha et al. [135] também sintetizaram PAni/n- $\mathrm{TiO}_{2}$ em $\mathrm{HCl}$ por via química, e observaram uma morfologia semelhante a aqui obtida nas sínteses a $0{ }^{\circ} \mathrm{C}$ todavia, os autores também não mencionam a temperatura usada na síntese.

De forma geral, o bom recobrimento de aglomerados de $\mathrm{n}-\mathrm{TiO}_{2}$ pela PAni é devido à atração eletrostática dos nanotubos e aos monômeros de anilina durante os primeiros estágios de nucleação. $\mathrm{O}$ n- $\mathrm{TiO}_{2}$ disperso em meio ácido apresenta uma carga superficial positiva de acordo com medidas de potencial zeta (o ponto de carga zero ocorre a $\mathrm{pH}=5,9$ ). Em meio ácido, a carga da superfície dos nanotubos é compensada pela adsorção de íons $\mathrm{HSO}_{4}{ }^{-}$ao longo da superfície. A carga negativa global induzida dos nanotubos em meio ácido gera uma atração eletrostática com os monômeros iônicos de anilina (positivamente carregados em meio ácido). Devido a esta atração eletrostática, as partículas de $\mathrm{n}-\mathrm{TiO}_{2}$ agem como centros de nucleação da polimerização e as cadeias de polímero crescem ao redor das delas, aumentando assim sua área superficial. 


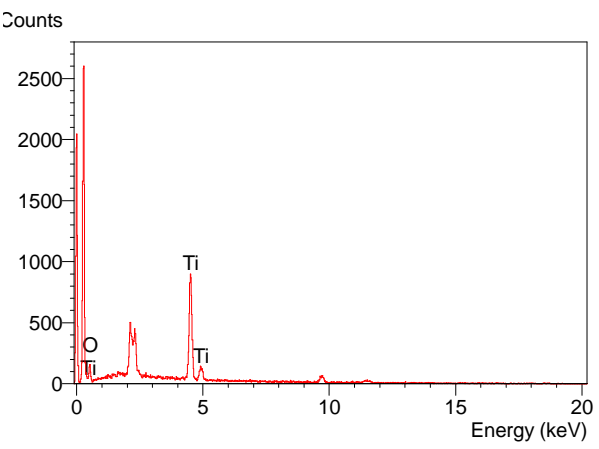

(a)

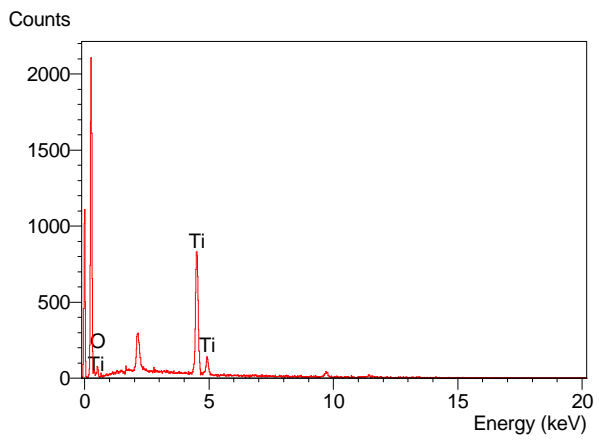

(c)

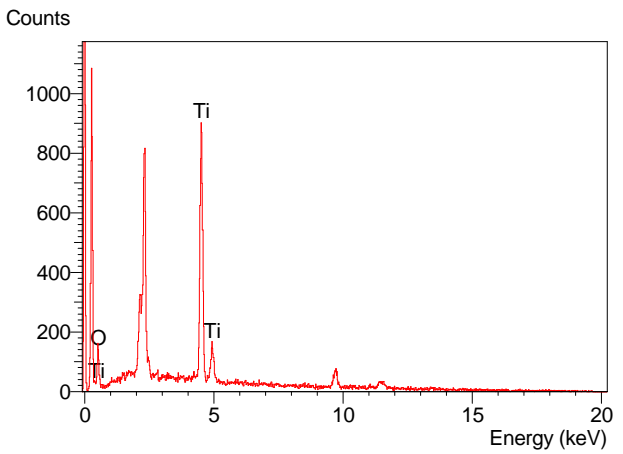

(b)

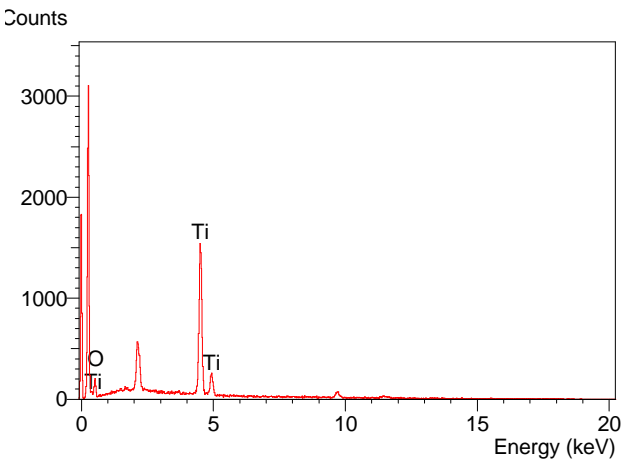

(d)

Figura 65 - Análise de EDX para determinação da composição química de Ti nos compósitos (em pó). PAni/n$\mathrm{TiO}_{2}$ dopado, sintetizado à (a) 0 e (b) $25^{\circ} \mathrm{C} ; \mathrm{PAni} / \mathrm{n}-\mathrm{TiO}_{2}$ desdopado, sintetizado à (c) 0 e (d) $25^{\circ} \mathrm{C}$.

Tabela 13 - Composição química de compósito $\mathrm{PAni} / \mathrm{n}-\mathrm{TiO}_{2}$ (em pó) dopado e desdopado, obtida a partir de análise de EDX (Fig. 65)

\begin{tabular}{|c|cc|cc|}
\hline & \multicolumn{2}{|c|}{ Dopados } & \multicolumn{2}{c|}{ Desdopados } \\
Elemento & $\mathbf{T}=\mathbf{0}^{\mathbf{}} \mathbf{C}$ & $\mathbf{T}=\mathbf{2 5}^{\mathbf{}} \mathbf{C}$ & $\mathbf{T}=\mathbf{0}^{\mathbf{}} \mathbf{C}$ & $\mathbf{T}=\mathbf{2 5}^{\circ} \mathbf{C}$ \\
\hline $\mathrm{C}$ & 65,87 & 48,16 & 48,16 & 57,34 \\
$\mathrm{O}$ & 16,14 & 26,87 & 26,87 & 20,18 \\
$\mathrm{Ti}$ & 17,99 & 24,97 & 24,96 & 22,47 \\
\hline
\end{tabular}

De acordo com outros trabalhos, a estrutura casca-caroço (ou encapsulamento) da PAni apresenta efeitos controversos. Por um lado, a estrutura casca-caroço induz à formação de um polímero altamente poroso, aumentando a área da interface sólido-líquido e aumentando os caminhos possíveis para difusão de íons. Mas alguns autores acreditam que PAni (que apresenta dopagem tipo p) e $\mathrm{TiO}_{2}$ (dopagem tipo n) podem formar uma junção p-n que poderia causar um efeito benéfico contra os processos de corrosão. 
Como a PAni apresenta dopagem tipo p, ela se constitui como uma boa barreira ao transporte de elétrons, inibindo as reações 20 e 21 . Por outro lado, elementos semicondutores tipo n, como o titânio, podem retardar as reações de redução 22 e 23. Esta propriedade torna este material testado bastante interessante para ser utilizado como revestimento protetor [139, $140,146,147]$.

Juntamente com as análises por MEV, foram feitas análises da composição química das amostras por meio de um detector de raios-X acoplado ao microscópio (Fig. 65), para analisar as porcentagens de $\mathrm{TiO}_{2}$ nos polímeros (Tabela 13), e sua variação nos estados dopado e desdopado. Nos polímeros dopados, a porcentagem de $\mathrm{TiO}_{2}$ é menor nos materiais obtidos a baixas temperaturas de síntese. Contudo, deve ser levado em conta que esta análise é semi quantitativa, referindo-se somente à superfície da amostra, sem levar em conta o seio do material, e tampouco às quantidades totais de cada elemento em toda a amostra. Assim, o que estes resultados fornecem são informações sobre a composição química superficial que se encontra exposta, passível de ser analisada por este método.

Durante a síntese, provavelmente o $\mathrm{TiO}_{2}$ serve de núcleo para polimerização da PAni (como será discutido posteriormente); as partículas de óxido recobertas pelo polímero ficam mascaradas, não sendo portanto possível identificá-las na análise de EDX. Levando-se em conta o procedimento adotado para desdopagem do polímero, não são esperadas perdas significativas do $\mathrm{n}-\mathrm{TiO}_{2}$.

Assim, assumindo-se que a quantidade de $\mathrm{n}-\mathrm{TiO}_{2}$ nos polímeros não sofreu grande variação, a maior quantidade do óxido identificada no polímero dopado sintetizado a baixa temperatura é justificada pela cinética mais lenta da reação, a qual permitiu haver mais tempo para as cadeias poliméricas se formarem ao redor das partículas de $\mathrm{TiO}_{2}$, "encapsulando" o óxido. Assim, as partículas de $\mathrm{TiO}_{2}$ "encapsuladas" não apresentam resposta na análise de EDX, resultando por isso em menor quantidade na análise. Na síntese a $25^{\circ} \mathrm{C}$, as cadeias se formaram mais rapidamente, havendo menos tempo para que elas se ordenassem ao redor das nanopartículas de $\mathrm{TiO}_{2}$. Assim, menos partículas ficaram "encapsuladas" e, por isso, apareceram em maior proporção na análise.

Comparando-se a quantidade de $\mathrm{Ti}$ entre os polímeros dopados e desdopados, se observa um maior aumento do elemento naqueles sintetizados a $0{ }^{\circ} \mathrm{C}$. Isso ocorre porque cadeias de PAni podem ter se desprendido do $\mathrm{TiO}_{2}$ durante o processo de desdopagem, diminuindo assim a quantidade de partículas de $\mathrm{TiO}_{2}$ encapsuladas. $\mathrm{Na}$ síntese a $25{ }^{\circ} \mathrm{C}$ a variação na quantidade de $\mathrm{Ti}$ foi bem menor; isto ocorre porque no polímero dopado a quantidade de partículas de $\mathrm{TiO}_{2}$ encapsuladas já não era tão grande, e o processo de 


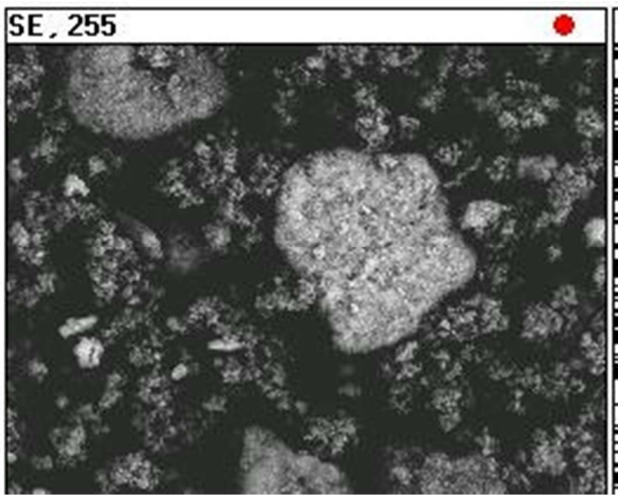

(a)

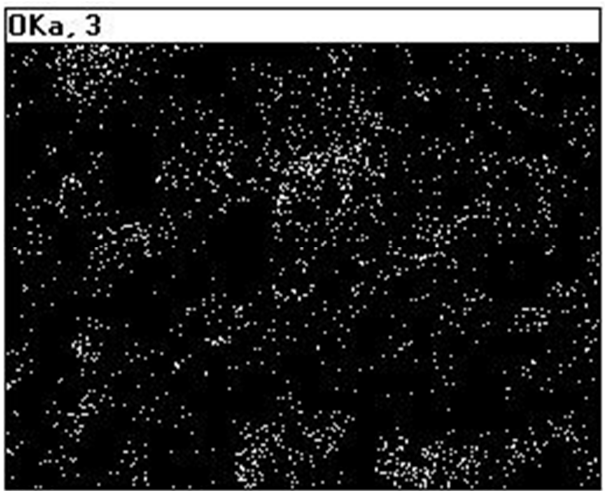

(c)

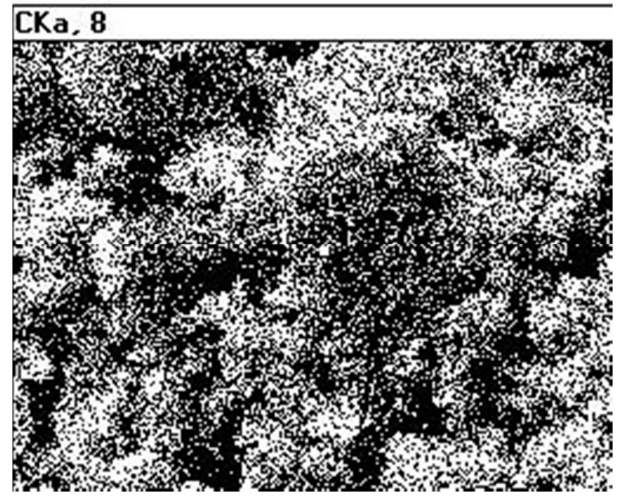

(b)

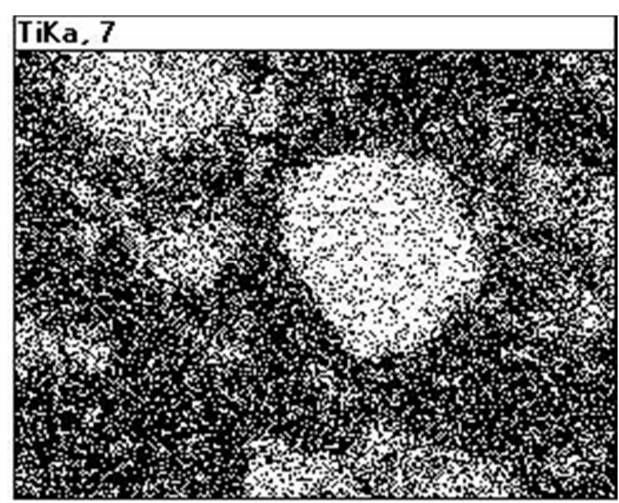

(d)

Figura 66 - Análise de EDX para fazer mapeamento da distribuição de elementos químicos na amostra de PAni $/ \mathrm{n}-\mathrm{TiO}_{2} 0^{\circ} \mathrm{C}$, a partir de (a) imagem de MEV. Elementos mapeados: (b) C, (c) O e (d) Ti.

desdopagem não alterou tanto a quantidade de partículas de $\mathrm{TiO}_{2}$ encapsuladas. As imagens de MEV (Fig. 63) dos polímeros dopados dão suporte a este argumento, pois as micrografias mostram que, para os polímeros dopados, a PAni $0{ }^{\circ} \mathrm{C}$ (Fig. 63c) apresenta uma morfologia de partículas aproximadamente esféricas, enquanto que a PAni $25^{\circ} \mathrm{C}$ (Fig. 63d) apresenta mais uma forma de "placas".

Diante destes resultados, algo contestável é se existe diferença entre realizar a síntese em presença de $\mathrm{TiO}_{2}$ ou simplesmente adicioná-lo após o polímero ser sintetizado e desdopado. Mesmo que no processo de desdopagem parte das partículas de $\mathrm{TiO}_{2}$ deixem de estar encapsuladas, não se pode afirmar que a presença do óxido no meio reacional durante a síntese equivale a adicioná-lo após finalizada a síntese, ou seja, estes dois procedimentos não são equivalentes. As partículas de $\mathrm{n}-\mathrm{TiO}_{2}$ servem como núcleos para a polimerização e, devido às suas dimensões nanométricas, a síntese na presença de $\mathrm{n}-\mathrm{TiO}_{2}$ resulta em maior área superficial do polímero. Além disso, é improvável que a totalidade das partículas de n- $\mathrm{TiO}_{2}$ deixe de ficar encapsulada. 
Para verificar a distribuição do $\mathrm{n}-\mathrm{TiO}_{2}$ (não encapsulado) pela matriz do polímero, foi feito um mapeamento dos elementos C, O e Ti (Fig. 66) na superfície do compósito em pó (desdopado). A amostra utilizada foi de $\mathrm{PAni} / \mathrm{n}-\mathrm{TiO}_{2} 0^{\circ} \mathrm{C}$, por apresentar, no estado dopado, maior encapsulamento. Pela análise se pode observar que partículas de Ti se encontram uniformemente distribuídas por toda região analisada. Estas partículas podem ainda se aglomerar e formar "ilhas" maiores, como pode ser visualizado pela Fig. 66d. Assim, por esta análise, dois padrões diferentes de distribuição do Ti são observados ao longo da amostra, partículas pequenas homogeneamente distribuídas e aglomerados maiores, estes últimos em menor proporção.

\subsubsection{Recobrimento de aço carbono 1020 com revestimentos de PAni e PAni/n-TiO}

As amostras de aço 1020 com PAni e PAni/n- $\mathrm{TiO}_{2}$, sintetizados a diferentes temperaturas, apresentaram diferentes características e morfologias (Fig. 67). Por estas imagens, observa-se que as amostras apresentaram, de forma geral, boa uniformidade e bom grau de recobrimento. A diferença mais visível é na amostra recoberta com $\mathrm{PAni} / \mathrm{TiO}_{2} 25^{\circ} \mathrm{C}$ (Fig. 67d), em que uma coloração violeta pode ser vista, resultado da presença do n- $\mathrm{TiO}_{2}$. Observando-se as imagens de microscopia óptica (Fig. 68), maiores diferenças são observadas entre os revestimentos. O revestimento PAni $25^{\circ} \mathrm{C}$ (Fig. 68b) apresentou maior uniformidade que PAni $0{ }^{\circ} \mathrm{C}$ (Fig. 68a). O polímero sintetizado à menor temperatura de síntese apresentou irregularidades em sua superfície, semelhante a bolhas formadas durante a secagem; neste sentido, o revestimento PAni $25^{\circ} \mathrm{C}$ mostrou-se muito mais homogêneo.

Os filmes de PAni/n-TiO 2 (Fig. 68 (c,d)) apresentaram morfologias semelhantes, com uma superfície mais heterogênea, marcada por pequenos círculos violetas, devido à presença do $\mathrm{n}-\mathrm{TiO}_{2}$. Por meio de imagens de MEV (Fig. 69) é possível verificar em maior grau as diferenças entre os filmes. O revestimento que apresentou maior homogeneidade foi o de PAni $25^{\circ} \mathrm{C}$ (Fig. 69b). O revestimento de PAni $0{ }^{\circ} \mathrm{C}$ não é tão homogêneo como o de PAni 25 ${ }^{\circ} \mathrm{C}$, porém é menos rugoso que os revestimentos de $\mathrm{PAni} / \mathrm{n}-\mathrm{TiO}_{2}$ (Fig. 69 (c,d)). Os revestimentos com o óxido, por sua vez, apresentam-se muito semelhantes entre si.

Assim, as imagens de fotografias, microscopia óptica e eletrônica corroboraram entre si. Sathiyanarayanan et al. [148] sintetizaram PAni em meio de $\mathrm{H}_{3} \mathrm{PO}_{4}$, e utilizaram o polímero como revestimento protetor em aço carbono. A morfologia do polímero, contudo, se assemelha mais à PAni $0{ }^{\circ} \mathrm{C}$, uma vez que não foi obtida pelos autores homogeneidade comparável ao recobrimento PAni $25^{\circ} \mathrm{C}$. 


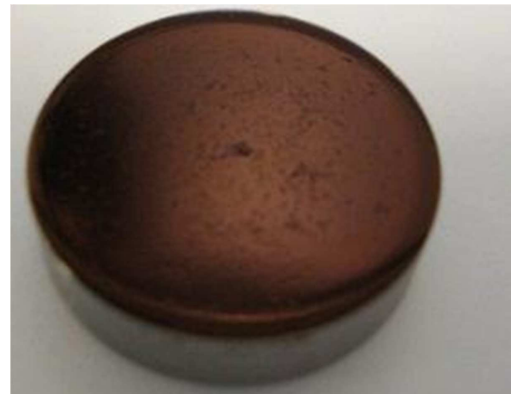

(a)

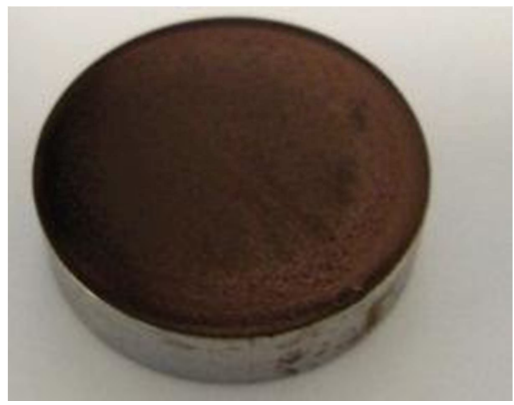

(c)

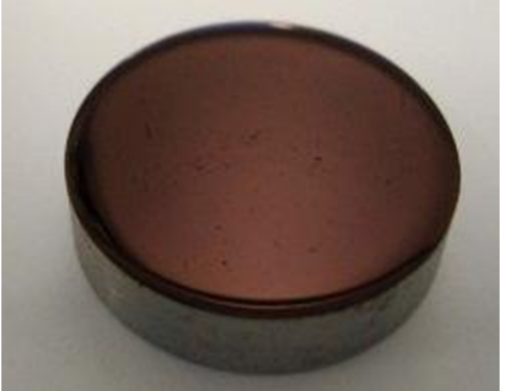

(b)

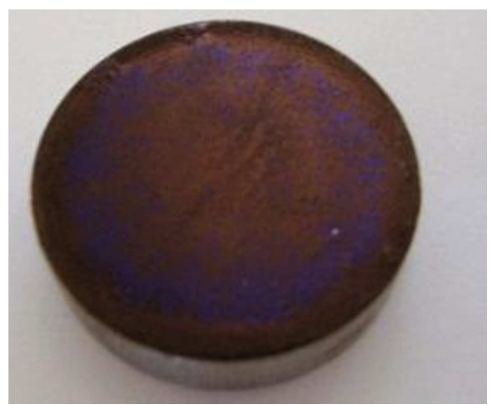

(d)

Figura 67 - Fotos de aços carbono 1020 com 1 camada de diferentes recobrimentos: PAni (a) 0 e (b) $25^{\circ} \mathrm{C}$; e $\mathrm{PAni} / \mathrm{n}-\mathrm{TiO}_{2}$ : (c) 0 e (d) $25^{\circ} \mathrm{C}$.

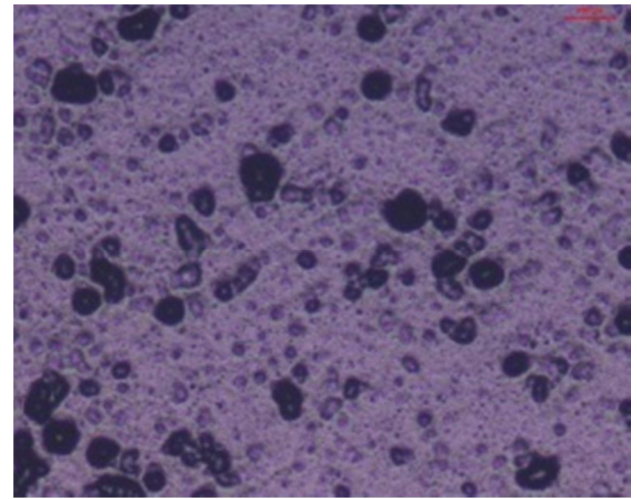

(a)

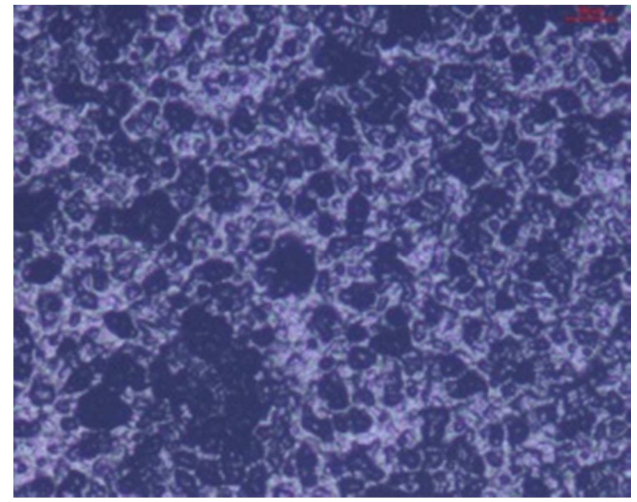

(c)

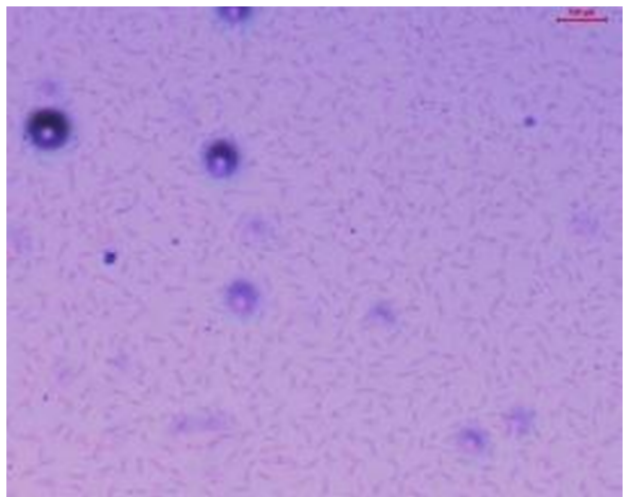

(b)

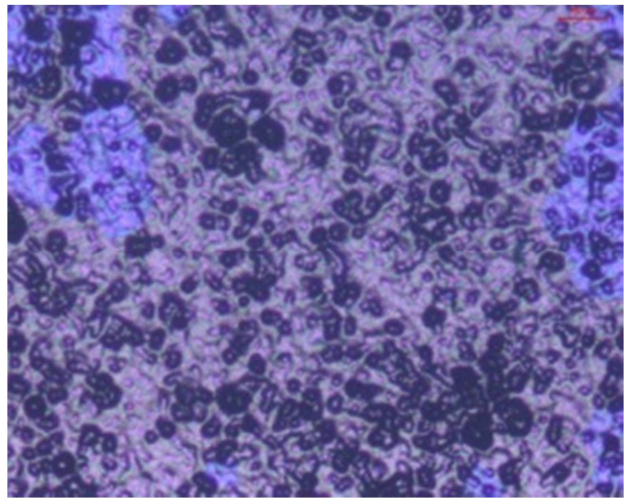

(d)

Figura 68 - Microscopia óptica de aços carbono 1020 com 1 camada de diferentes recobrimentos: PAni (a) 0 e (b) $25^{\circ} \mathrm{C}$; e PAni/n- $\mathrm{TiO}_{2}:$ (c) 0 e (d) $25^{\circ} \mathrm{C}$. 


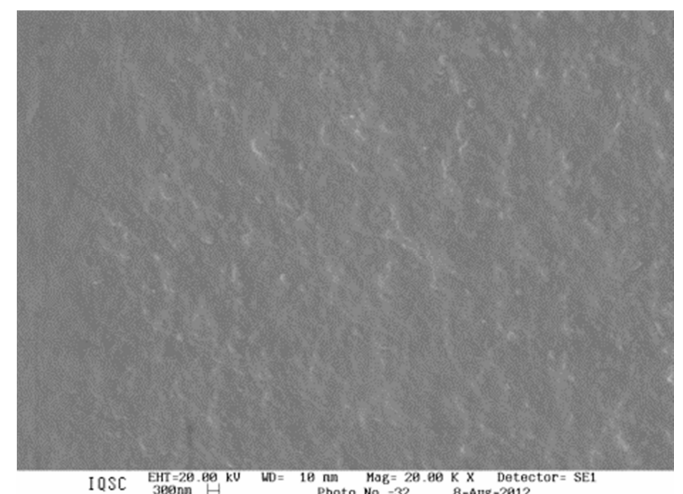

(a)

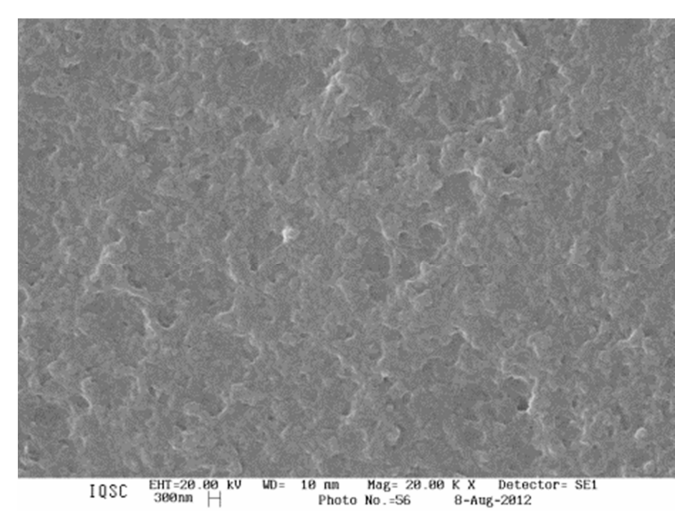

(c)

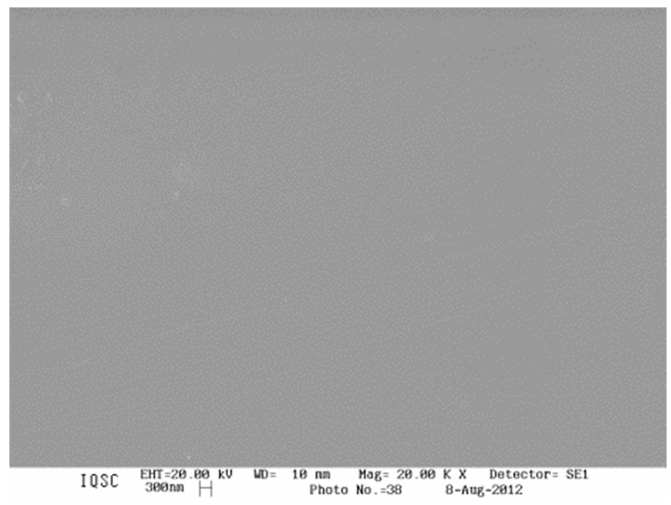

(b)

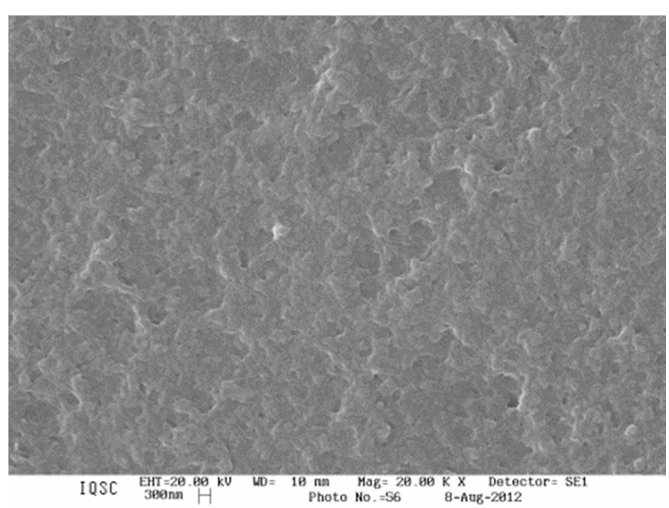

(d)

Figura 69 - MEV de aços carbono 1020 com 1 camada de diferentes recobrimentos: PAni (a) 0 e (b) $25^{\circ} \mathrm{C}$; e PAni/n- $\mathrm{TiO}_{2}$ : (c) 0 e (d) $25^{\circ} \mathrm{C}$.

Para verificar a eficiência dos recobrimentos, foram feitas análises de polarização potenciodinâmica em solução de $\mathrm{NaCl}$ 3,0\% (Fig. 70), utilizando a célula convencional. Os revestimentos mostraram-se, a princípio, eficientes em proteger o aço em meio de cloreto, o que pode ser visto pelo aumento nos potenciais de corrosão e abaixamento das correntes de corrosão nas curvas de polarização (Fig. 70). A análise dos parâmetros eletroquímicos (Tabela 14) mostra deslocamentos do potencial de corrosão que chagaram a quase $600 \mathrm{mV}$, e diminuição na corrente de corrosão na casa de 5 ordens de grandeza (para PAni $25^{\circ} \mathrm{C}$ ). A resistência de polarização também apresentou aumento muito pronunciado, que chegou a se deslocar 6 ordens de grandeza para este mesmo polímero. Estes resultados mostram que o revestimento está, a princípio, protegendo bem a superfície do aço. O melhor desempenho dos polímeros sem $\mathrm{n}-\mathrm{TiO}_{2}$ está relacionado à sua morfologia: a alta homogeneidade observada para a PAni $25^{\circ} \mathrm{C}$ resultou em que este polímero apresentou os melhores resultados enquanto revestimento. 


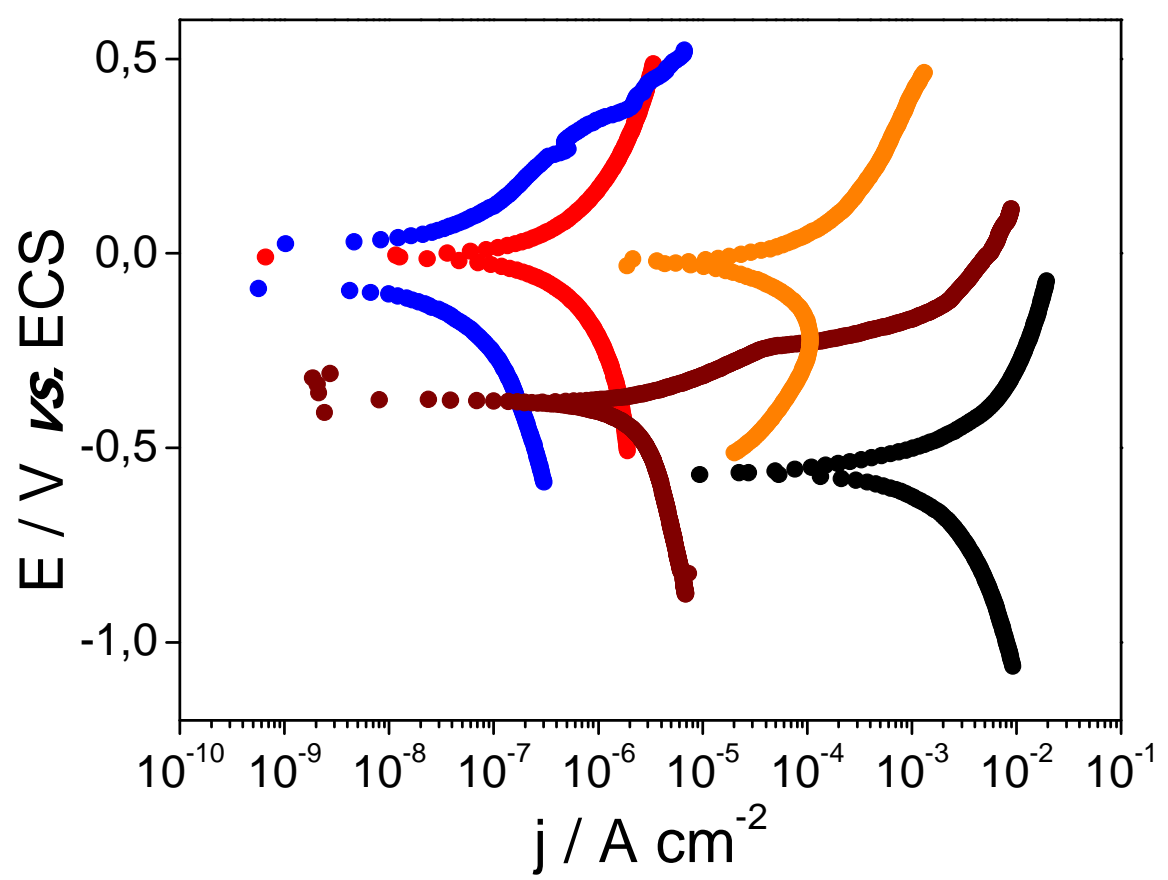

Figura 70 - Curvas de polarização potenciodinâmica - anódicas e catódicas (utilizando a célula convencional) em solução de $\mathrm{NaCl}$ 3,0\% de aço carbono 1020 com 1 camada de diferentes recobrimentos. • Aço 1020 sem recobrimento. Aços recobertos com: • PAni $0^{\circ} \mathrm{C}$; $\bullet$ PAni $25^{\circ} \mathrm{C}$; $\bullet$ PAni $/ \mathrm{n}-\mathrm{TiO}_{2} 0^{\circ} \mathrm{C}$; $\bullet$ PAni $/ \mathrm{n}^{-\mathrm{TiO}_{2}} 25^{\circ} \mathrm{C}$.

Tabela 14 - Parâmetros eletroquímicos obtidos a partir da análise das curvas de polarização potenciodinâmicas de aços carbono 1020 com 1 camada de recobrimentos de $\mathrm{PAni}$ e $\mathrm{PAni} / \mathrm{n}-\mathrm{TiO}_{2}$ sintetizados a diferentes temperaturas (Fig. 68)

\begin{tabular}{|c|c|c|c|c|c|c|c|}
\hline & $\mathrm{ba} / \mathrm{V} \mathrm{dec}^{-1}$ & bc/V dec ${ }^{-1}$ & $\mathrm{~B} / \mathrm{V} \operatorname{dec}^{-1}$ & $\mathbf{E}_{\text {corr }} / \mathbf{V}$ & $\mathbf{J}_{\mathrm{corr}} / \boldsymbol{\mu A} \mathbf{c m}^{-2}$ & T.C./mm ano ${ }^{-1}$ & $\mathbf{R p} / \mathbf{M} \Omega$ \\
\hline Aço C & 0,010 & 0,596 & 0,0043 & $-0,568$ & 3420 & 39,8 & $1,1510^{-6}$ \\
\hline Pani $0^{\circ} \mathrm{C}$ & 0,801 & 0,587 & 0,147 & $-0,009$ & 0,577 & 0,007 & 0,226 \\
\hline Pani $25^{\circ} \mathrm{C}$ & 0,270 & 0,372 & 0,068 & 0,045 & 0,0266 & 0,0003 & 2,26 \\
\hline PAni/n- $-\mathrm{TiO}_{2} \mathbf{0}^{\circ} \mathrm{C}$ & 1,07 & 0,123 & 0,048 & $-0,389$ & 2,54 & 0,029 & 0,0167 \\
\hline 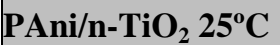 & 0,430 & 0,218 & 0,063 & $-0,034$ & 46,0 & 0,535 & 0,0013 \\
\hline
\end{tabular}




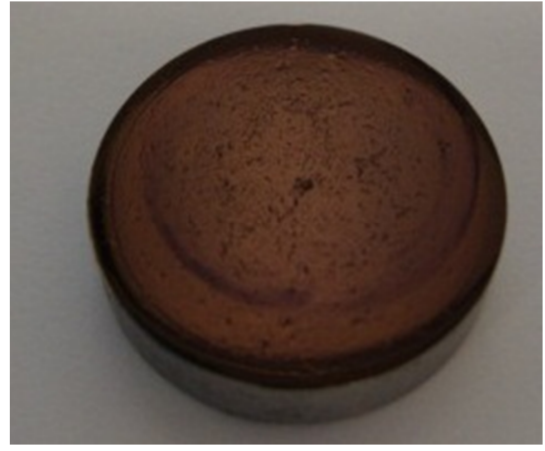

(a)

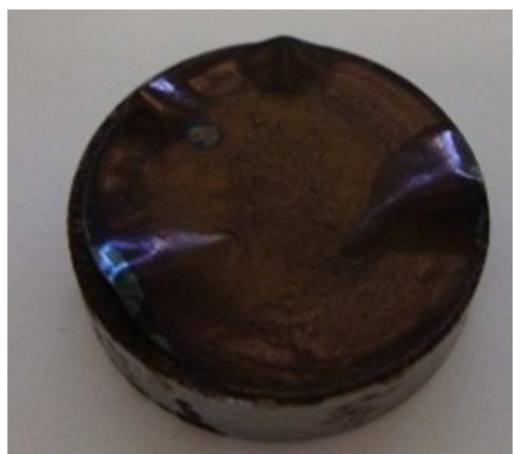

(c)

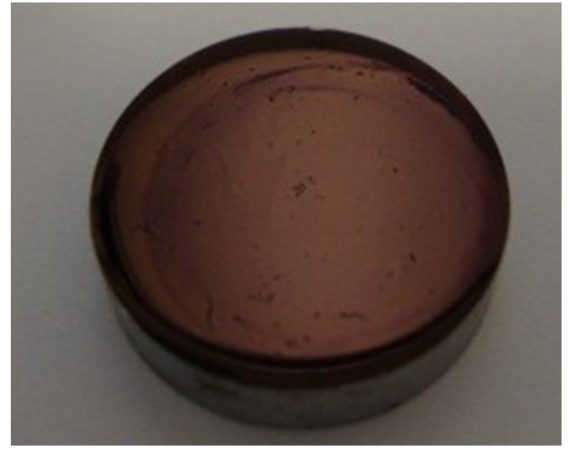

(b)

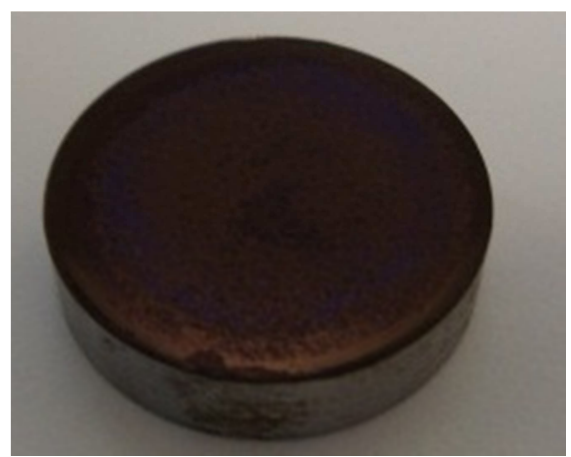

(d)

Figura 71 - Fotos dos aços carbono 1020 com 1 camada de diferentes revestimentos, após ensaio de polarização potenciodinâmica em $\mathrm{NaCl} 3,0 \%$. PAni (a) 0 e (b) $25^{\circ} \mathrm{C}$; $\mathrm{PAni} / \mathrm{n}-\mathrm{TiO}_{2}$ (c) 0 e (d) $25^{\circ} \mathrm{C}$.

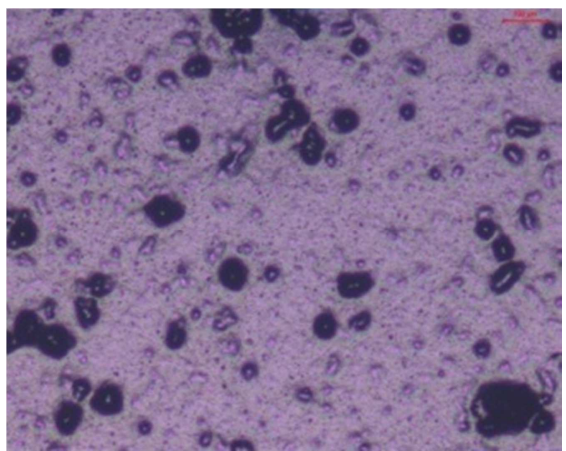

(a)

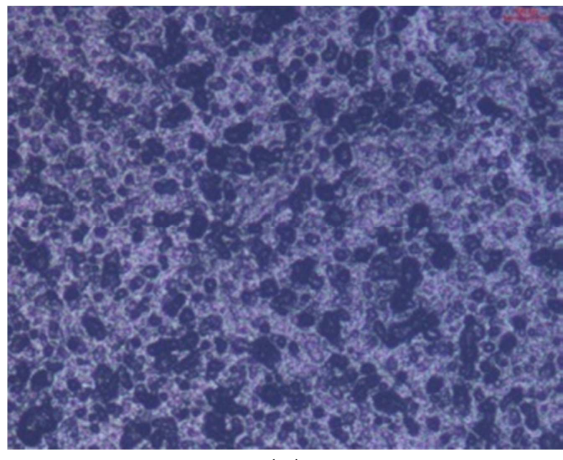

(c)

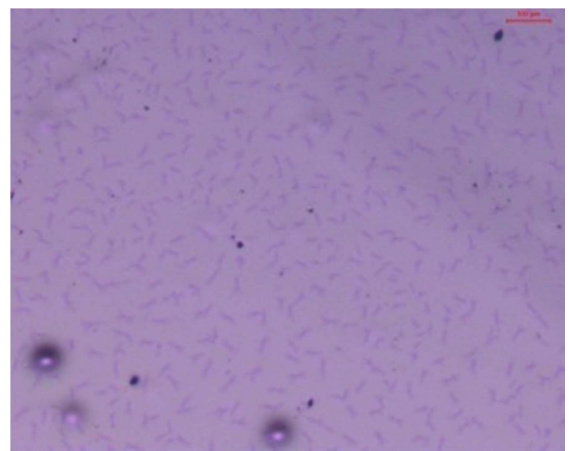

(b)

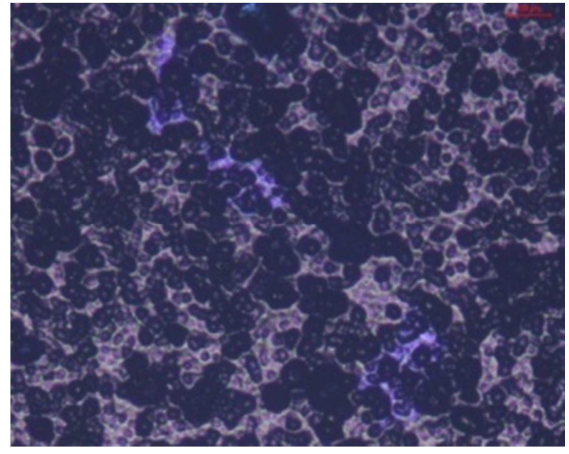

(d)

Figura 72 - Microscopia óptica dos aços carbono 1020 com 1 camada de diferentes revestimentos, após ensaio de polarização potenciodinâmica em $\mathrm{NaCl} 3,0 \%$. PAni (a) 0 e (b) $25^{\circ} \mathrm{C}$; PAni/n- $-\mathrm{TiO}_{2}$ (c) 0 e (d) $25^{\circ} \mathrm{C}$. 


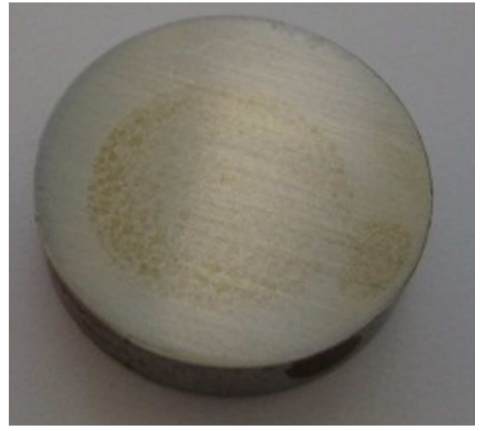

(a)

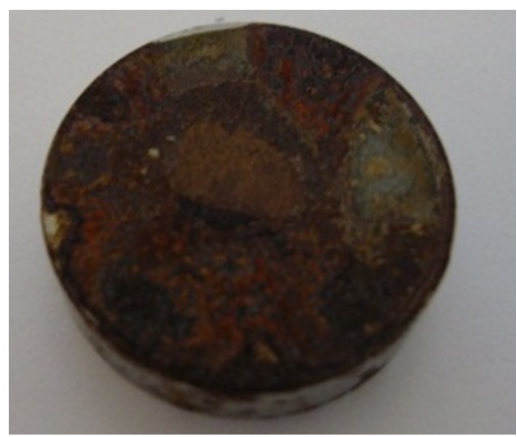

(c)

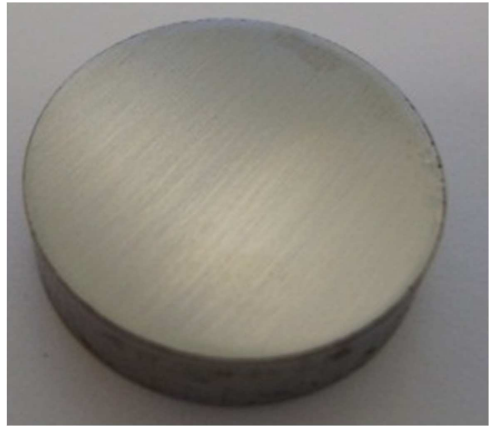

(b)

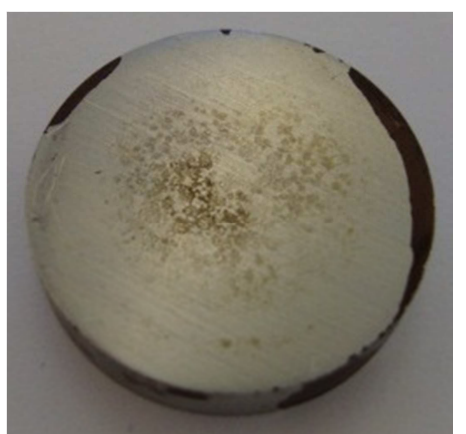

(d)

Figura 73 - Fotos dos aços carbono 1020 com 1 camada de diferentes revestimentos, após ensaio de polarização potenciodinâmica em $\mathrm{NaCl}$ 3,0\% e remoção dos revestimentos para exame da superfície. Filmes que foram retirados dos aços: PAni (a) 0 e (b) $25^{\circ} \mathrm{C}$; PAni $/ \mathrm{n}-\mathrm{TiO}_{2}$ (c) 0 e (d) $25^{\circ} \mathrm{C}$.

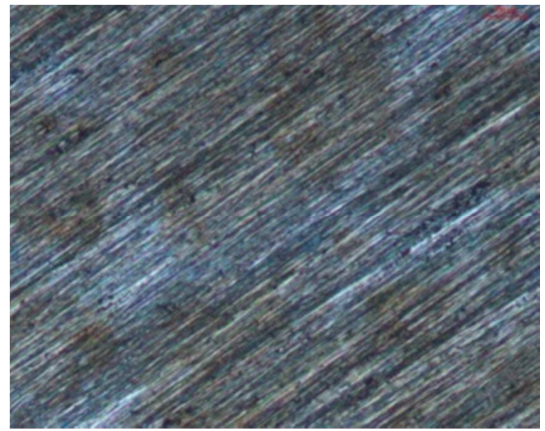

(a)

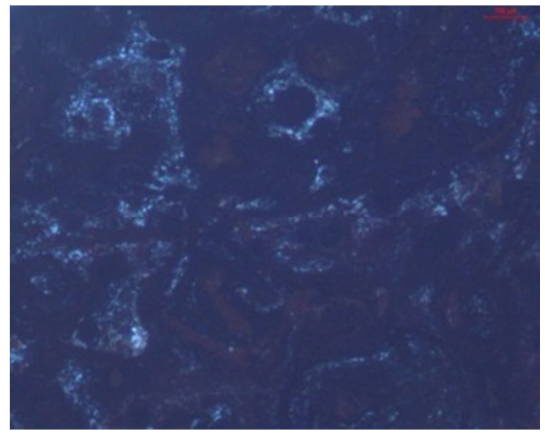

(c)

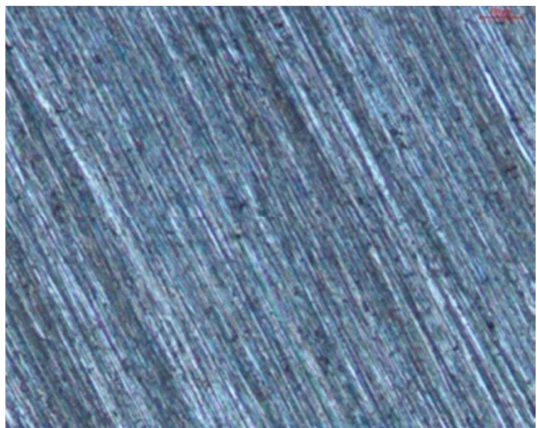

(b)

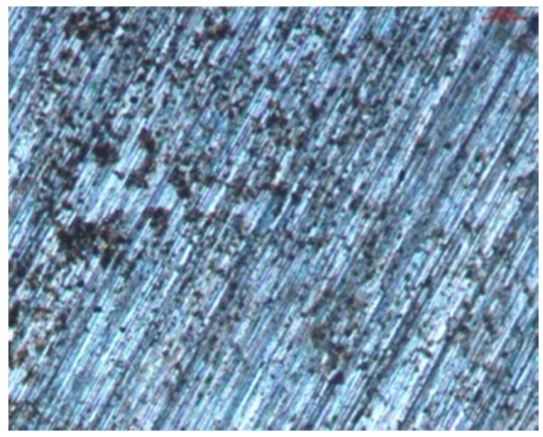

(d)

Figura 74 - Microscopia óptica dos aços carbono 1020 com 1 camada de diferentes revestimentos, após ensaio de polarização potenciodinâmica em $\mathrm{NaCl} 3,0 \%$ e remoção dos revestimentos para exame da superfície. Filmes que foram retirados dos aços: PAni (a) 0 e (b) $25^{\circ} \mathrm{C} ; \mathrm{PAni} / \mathrm{n}-\mathrm{TiO}_{2}$ (c) 0 e (d) $25^{\circ} \mathrm{C}$. 
Embora que do recobrimento de $\mathrm{n}-\mathrm{TiO}_{2}$ em conjunto com a PAni sejam esperados altos índices de proteção contra a corrosão, a morfologia destes revestimentos apresentou também alta heterogeneidade dos filmes. A presença do $\mathrm{n}-\mathrm{TiO}_{2}$ provavelmente gerou maior porosidade no filme de PAni, que culminou com resultados menos satisfatórios que os revestimentos do polímero sem $\mathrm{n}-\mathrm{TiO}_{2}$. Com relação aos filmes protetores, após as polarizações, as fotos e imagens de microscopia óptica revelam que os filmes não apresentam degradação significativa (Figs. 71 e 72). As imagens de microscopia óptica (Fig.72) mostram ainda que não ocorreram alterações da morfologia dos filmes com relação a fase anterior das análises. Além disso, quase todos os filmes apresentaram aderência durante as análises (Fig. 71), com exceção do filme de $\mathrm{PAni} / \mathrm{n}-\mathrm{TiO}_{2} \quad 0^{\circ} \mathrm{C}$, que se desprendeu da superfície, principalmente pelas bordas.

Um fator importante é observar se a superfície do aço de fato não sofreu nenhum ataque pelo ambiente corrosivo da solução de trabalho. Para isso, os filmes foram removidos da superfície, e estas foram observadas por fotos digitais (Fig. 73) e microscopia óptica (Fig. 74). As superfícies dos aços, após a remoção dos filmes, apresentam diferentes graus de ataque. $\mathrm{O}$ aço que estava com PAni $25^{\circ} \mathrm{C}$ não apresentou nenhum sinal de corrosão (Figs. 73b e 74b), como resultado de sua homogeneidade e boa aderência durante a análise. $\mathrm{O}$ aço que estava recoberto com PAni $0{ }^{\circ} \mathrm{C}$ apresentou a presença de óxido de produto de corrosão em sua superfície; pela imagem de microscopia óptica foi mais fácil observar o óxido de ferro formado pela sua corrosão (Figs. 73a e 74a). Possivelmente, por algum grau de porosidade do filme, a solução conseguiu penetrar através do revestimento, ainda que em pequena quantidade, mas suficiente para provocar um pequeno grau ataque, visível inclusive a olho nu.

$\mathrm{O}$ revestimento menos protetor foi o de $\mathrm{PAni} / \mathrm{n}-\mathrm{TiO}_{2} 0^{\circ} \mathrm{C}$, pois, como já comentado, após a análise este revestimento se desprendeu da superfície do aço. A superfície se mostrou muito atacada (Figs. 73c e 74c), com excesso de produtos de corrosão, mostrando que houve intenso contato entre a solução de $\mathrm{NaCl}$ e o aço. A combinação $\mathrm{PAni} / \mathrm{TiO}_{2} 0{ }^{\circ} \mathrm{C}$ não resultou em um revestimento com muita eficácia como proteção contra a corrosão. O revestimento de PAni $0{ }^{\circ} \mathrm{C}$ já havia se mostrado menos eficiente que PAni $25^{\circ} \mathrm{C}$ e a adição de partículas de n$\mathrm{TiO}_{2}$ provavelmente tenha aumentado a porosidade do filme, possibilitando a entrada de solução de $\mathrm{NaCl}$ e provocando corrosão, o que resultou no desprendimento do filme. Por fim, o aço que estava com o revestimento $\mathrm{PAni} / \mathrm{n}-\mathrm{TiO}_{2} 25^{\circ} \mathrm{C}$ apresentou sinais de corrosão (Figs. $73 \mathrm{~d}$ e $74 \mathrm{~d}$ ), mas em menor grau do que PAni $/ \mathrm{n}-\mathrm{TiO}_{2} 0{ }^{\circ} \mathrm{C}$. Isto corrobora com a tese de que o $\mathrm{n}-\mathrm{TiO}_{2}$ possa ter aumentado a porosidade no filme resultante. 


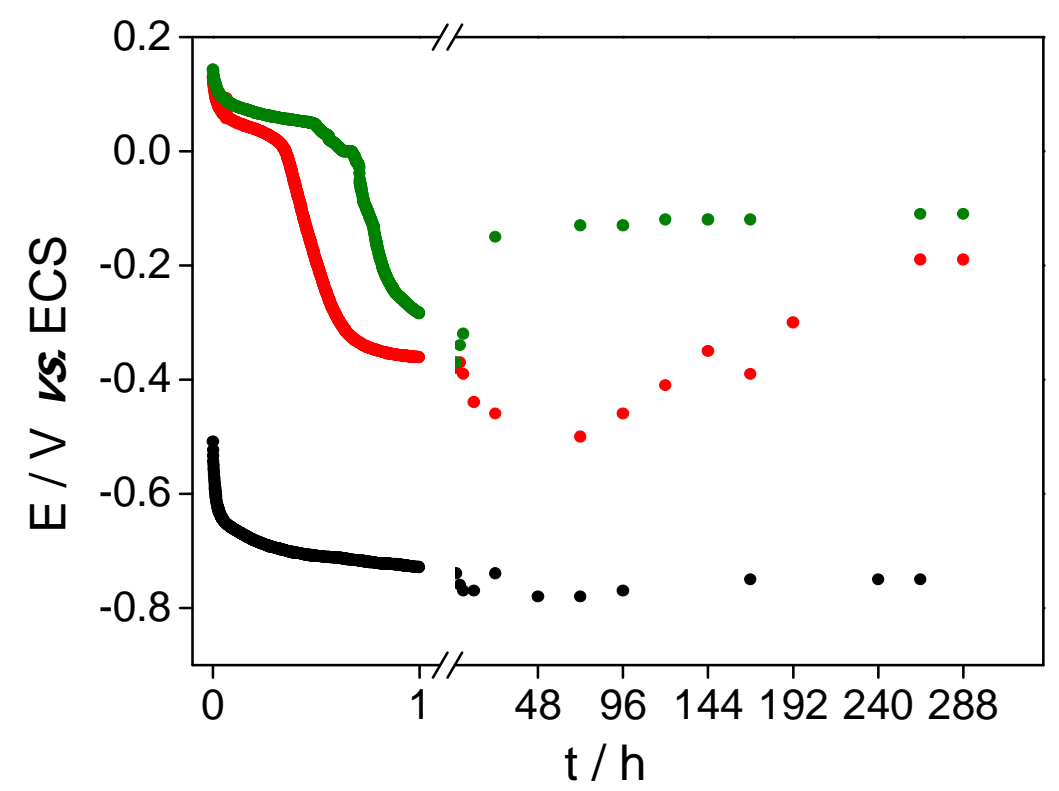

Figura 75 - Monitoramento do PCA de aço carbono 1020 em solução de $\mathrm{NaCl}$ 3,0\% de amostra de: • aço sem recobrimento; e recobertas com 1 camada de $\bullet$ Pani e $\bullet P A n i / n-\mathrm{TiO}_{2}$, ambos sintetizados a $25^{\circ} \mathrm{C}$.

$\mathrm{O}$ que se pode inferir destas análises é que os polímeros sintetizados a $25{ }^{\circ} \mathrm{C}$ apresentaram melhor desempenho que os correspondentes sintetizados a $0{ }^{\circ} \mathrm{C}$. Além disso, ainda que $\mathrm{n}-\mathrm{TiO}_{2}$ apresente propriedades que resultam em boas características na proteção contra a corrosão, o aumento da porosidade do filme causado por estas partículas prejudica o desempenho inicial deste, uma vez que solução de cloreto pode atingir a superfície do aço.

Como o Ti apresenta boas propriedades anticorrosivas, uma análise de monitoramento do potencial de circuito aberto (PCA) por um maior intervalo de tempo foi feita nas amostras de PAni e PAni/n- $\mathrm{TiO}_{2}$, ambas sintetizadas a $25^{\circ} \mathrm{C}$ (Fig. 75). Por esta análise, se observa que os aços com revestimentos mantiveram sempre um potencial de circuito aberto maior que o aço sem proteção. Os revestimentos apresentaram uma queda inicial no potencial de corrosão, mas após aproximadamente de $48 \mathrm{~h}$ este valor voltou a aumentar para os dois revestimentos analisados. O filme de PAni/n- $\mathrm{TiO}_{2}$, entretanto, é o que apresentou maior aumento, e de forma mais rápida. $\mathrm{O}$ revestimento de PAni $25{ }^{\circ} \mathrm{C}$ levou em torno de $96 \mathrm{~h}$ para começar a apresentar recuperação do potencial de corrosão. Assim, conclui-se que para maiores tempos de análise, o revestimento de $\mathrm{PAni} / \mathrm{n}-\mathrm{TiO}_{2}$ começou a mostrar melhor eficiência. O que limita uma maior eficiência deste revestimento, até esta etapa, é sua porosidade, aparentemente maior que a do filme sem n- $\mathrm{TiO}_{2}$. 


\subsubsection{Influência do número de camadas no desempenho de revestimentos PAni e PAni/n-} $\mathrm{TiO}_{2}$

Pelas análises anteriores foi observado que os revestimentos sintetizados a $0{ }^{\circ} \mathrm{C}$ não resultaram em eficiência comparável aos revestimentos sintetizados a $25^{\circ} \mathrm{C}$. Além disso, a adição de $\mathrm{n}-\mathrm{TiO}_{2}$ no filme de PAni provocou um aumento em sua porosidade, o que resultou em pior proteção contra a corrosão devido à permeação da solução de cloreto. Assim, nesta etapa, objetivando a união das propriedades anticorrosivas do Ti e solucionar o problema da porosidade do filme, várias camadas do revestimento ( 1 a 3 camadas) foram aplicadas sobre a superfície do aço carbono.

Curvas de polarização potenciodinâmicas (Fig. 76) foram feitas com uma célula convencional e os respectivos parâmetros eletroquímicos estão apresentados na Tabela 16. Os resultados mostram uma tendência inversa entre a PAni e $\mathrm{PAni} / \mathrm{n}-\mathrm{TiO}_{2}$ com relação ao aumento do número de camadas. Enquanto que o aumento de camadas de PAni tornou este revestimento menos protetor, este aumento no caso de $\mathrm{PAni} / \mathrm{n}-\mathrm{TiO}_{2}$ levou a uma melhora progressiva da proteção contra a corrosão.

No caso da PAni, a cada nova camada que foi depositada, a corrente de corrosão praticamente aumentou em uma ordem de grandeza. No caso da PAni/n- $\mathrm{TiO}_{2}$, ocorreu justamente o inverso: a segunda camada diminui significativamente a corrente de corrosão em duas ordens de grandeza, e a adição de uma terceira camada diminuiu a corrente de corrosão em mais uma ordem de grandeza. A resistência de polarização, $R_{p}$, diminuiu significativamente com o aumento do número de camadas de PAni e aumentou consideravelmente para a $\mathrm{PAni} / \mathrm{n}-\mathrm{TiO}_{2}$. A variação do $\mathrm{E}_{\text {corr }}$ foi maior da primeira para a segunda camada nos dois polímeros, sendo que na terceira camada este valor permaneceu aproximadamente constante.

Este comportamento pode ser mais bem entendido pela análise das fotografias das amostras de aço com os recobrimentos (antes de qualquer ensaio experimental, Fig. 77). Pode ser concluído que o aumento do número de camadas de PAni causa um enrugamento do filme mas, e nos revestimentos com n- $\mathrm{TiO}_{2}$ aparentemente não há alteração da morfologia do filme. Imagens de microscopia óptica auxiliaram na análise da homogeneidade dos revestimentos (Fig. 78), pela qual foi constatado que não ocorreram alterações na morfologia e homogeneidade dos filmes pela adição de uma nova camada, exceto para o caso do revestimento de PAni, que sofreu enrugamento com adição de 2 ou 3 camadas. 


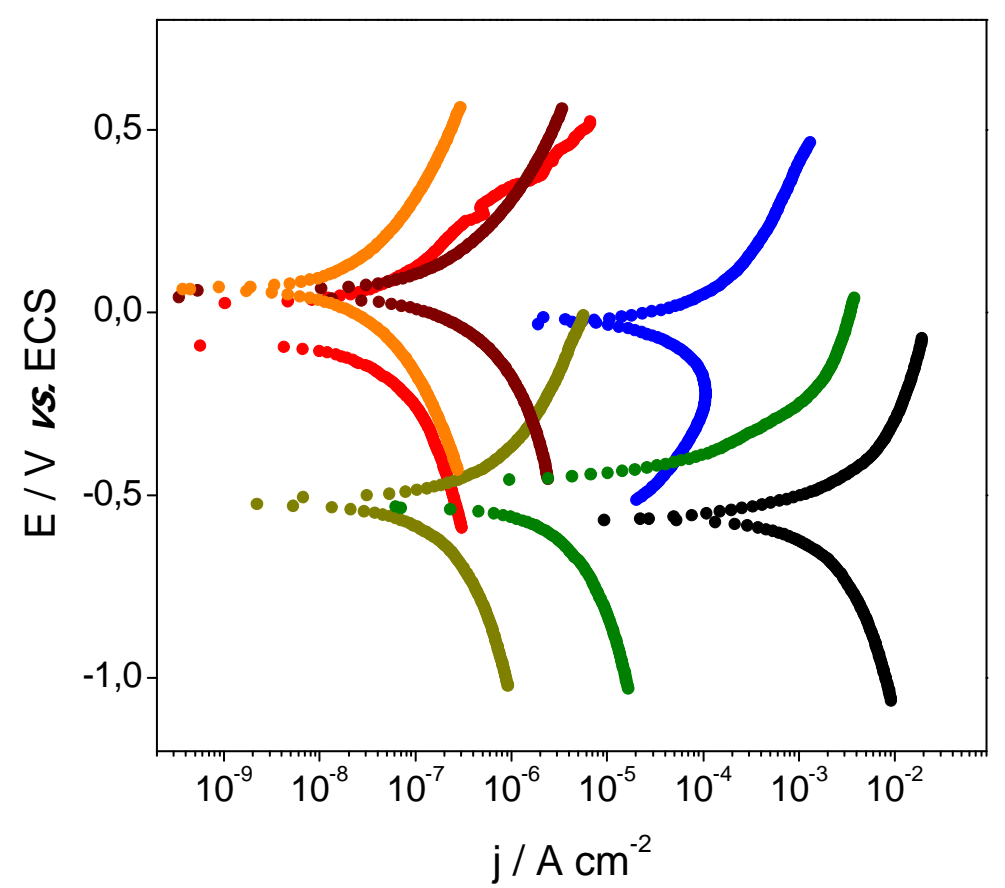

Figura 76 - Curvas de polarização potenciodinâmica em solução de $\mathrm{NaCl}$ 3,0\% de aço carbono 1020 com multicamadas de diferentes recobrimentos $\left(\mathrm{T}_{\text {síntese }}=25^{\circ} \mathrm{C}\right)$. Aço 1020 sem recobrimento. Recobrimentos de PAni com: $\bullet 1$, 2 e $\bullet 3$ camadas; recobrimentos de $\mathrm{PAni} / \mathrm{n}-\mathrm{TiO}_{2}$ com: $\bullet 1, \bullet 2$ e $\bullet 3$ camadas.

Tabela 15 - Parâmetros eletroquímicos obtidos da análise das curvas de polarização em solução de $\mathrm{NaCl} 3,0 \%$ de aços carbono 1020 com multicamadas de diferentes recobrimentos (Fig. 76)

\begin{tabular}{|c|c|c|c|c|c|c|c|c|}
\hline & & ba/V dec dec $^{-1}$ & bc/V dec ${ }^{-1}$ & B/ V dec dec $^{-1}$ & $\mathbf{E}_{\text {corr }} / \mathbf{V}$ & $\mathbf{j}_{\text {corr }} / \mu \mathrm{A} \mathrm{cm} \mathbf{c m}^{-2}$ & T.C./mm ano ${ }^{-1}$ & $\mathbf{R p} / \mathrm{M} \Omega$ \\
\hline & Aço 1020 & 0,010 & 0,596 & 0,0043 & $-0,568$ & 3420 & 39,8 & $1,1510^{-6}$ \\
\hline \multirow{3}{*}{ PAni } & 1 camada & 0,270 & 0,372 & 0,068 & 0,045 & 0,0266 & 0,0003 & 2,26 \\
\hline & 2 camadas & 0,594 & 0,245 & 0,075 & $-0,543$ & 0,159 & 0,0018 & 0,157 \\
\hline & 3 camadas & 0,060 & 0,314 & 0,022 & $-0,502$ & 1,34 & 0,0156 & 0,0145 \\
\hline \multirow{3}{*}{ PAni/n-TiO 2} & 1 camada & 0,430 & 0,218 & 0,063 & $-0,034$ & 46,0 & 0,535 & 0,0013 \\
\hline & 2 camadas & 0,410 & 0,420 & 0,090 & 0,055 & 0,224 & 0,0026 & 0,302 \\
\hline & 3 camadas & 0,454 & 0,426 & 0,096 & 0,080 & 0,0282 & 0,000328 & 2,99 \\
\hline
\end{tabular}

Imagens de MEV foram feitas dos revestimentos de PAni e PAni/n- $\mathrm{TiO}_{2}$, com 1 e 3 camadas (Fig. 79). As imagens com ampliação de 20.000 vezes mostram que, de fato, não ocorreu mudança na homogeneidade do filme pela adição de novas camadas (a foto de MEV de PAni 3 camadas (Fig. 79b) foi tirada em uma região sem enrugamento). 


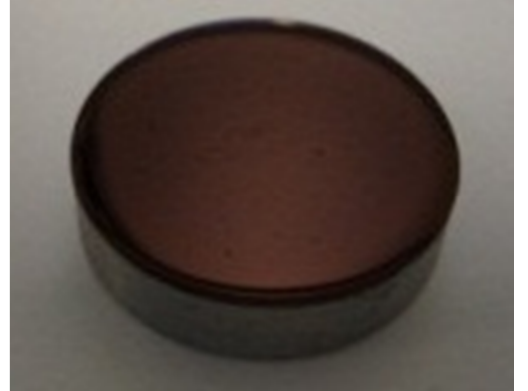

(a)

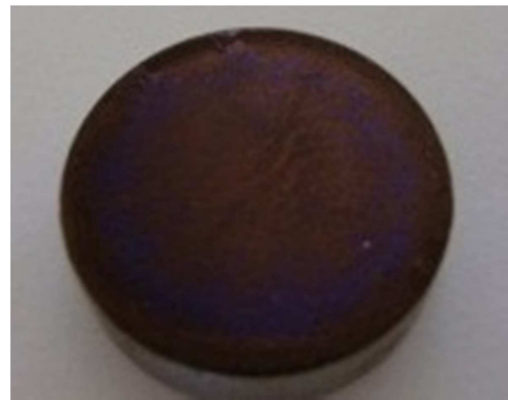

(d)

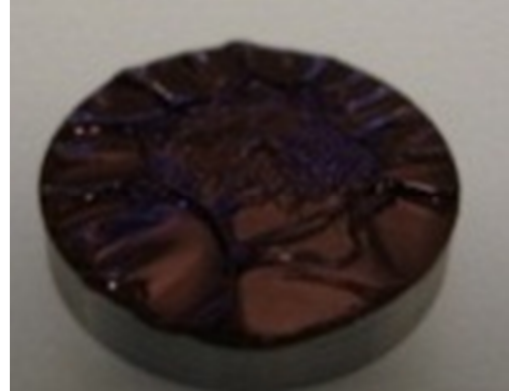

(b)

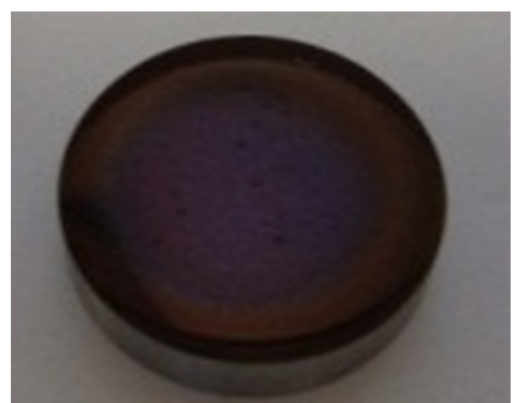

(e)

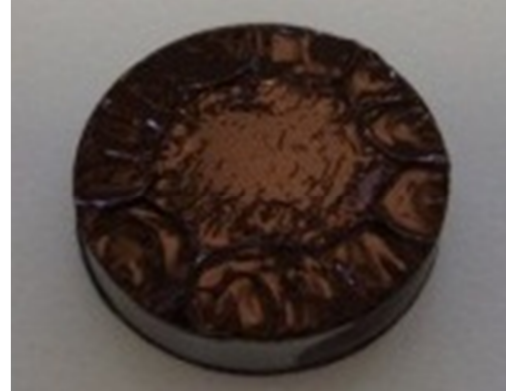

(c)

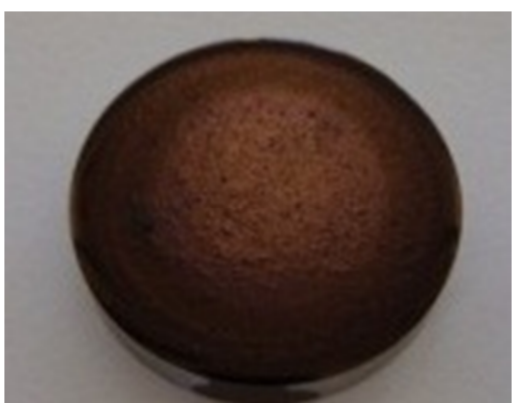

(f)

Figura 77 - Fotos de aços carbono 1020 com recobrimentos de PAni com (a) 1, (b) 2 e (c) 3 camadas, e PAni/n$\mathrm{TiO}_{2}$ com (d) 1 , (e) 2 e (f) 3 camadas.

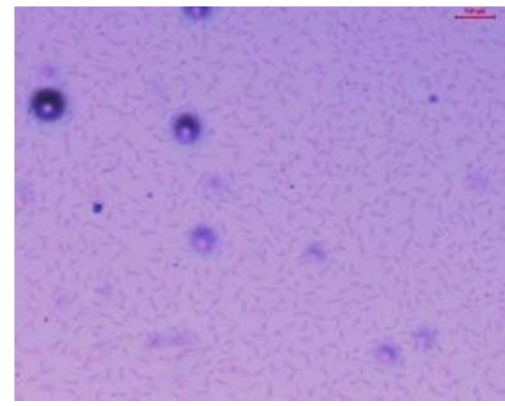

(a)

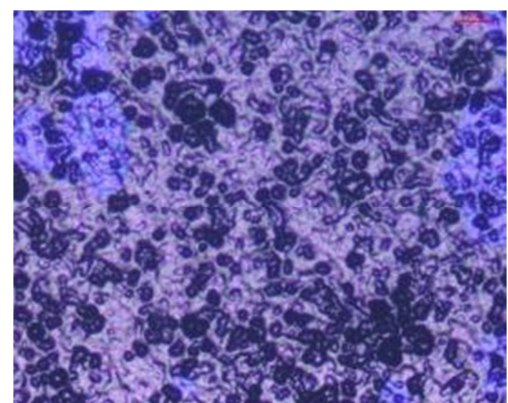

(d)

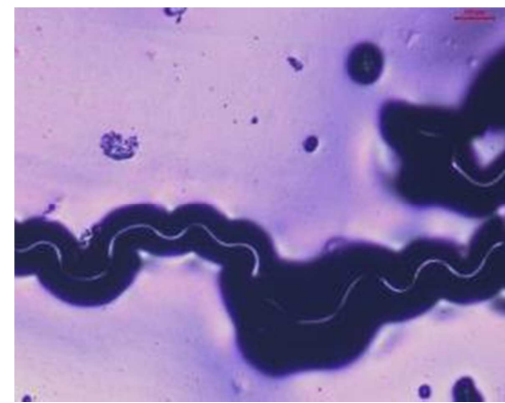

(b)

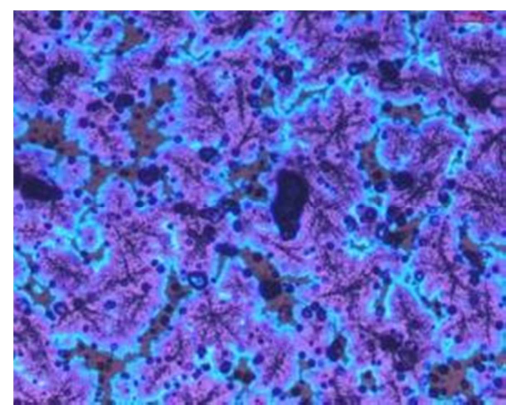

(e)

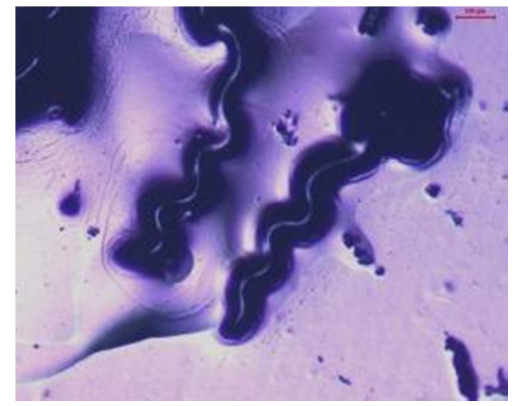

(c)

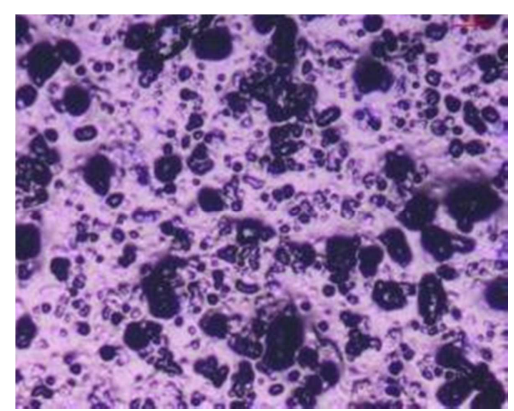

(f)

Figura 78 - Microscopia óptica de aços carbono 1020 com recobrimentos de PAni com (a) 1, (b) 2 e (c) 3 camadas, e PAni/n- $-\mathrm{TiO}_{2}$ com (d) 1 , (e) 2 e (f) 3 camadas. 


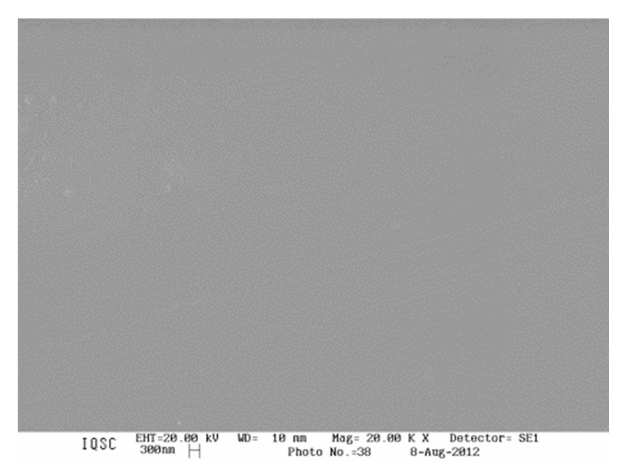

(a)

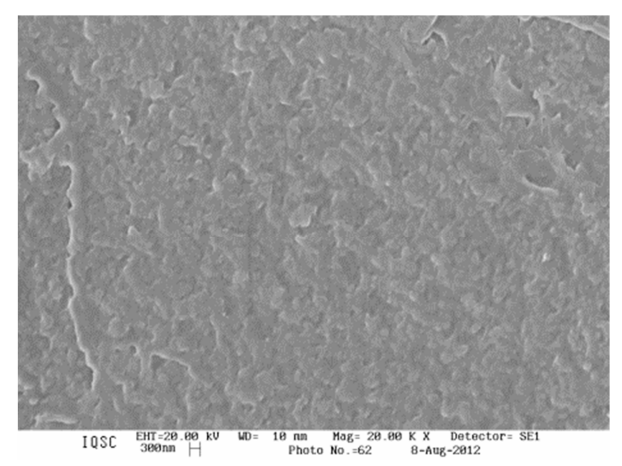

(c)

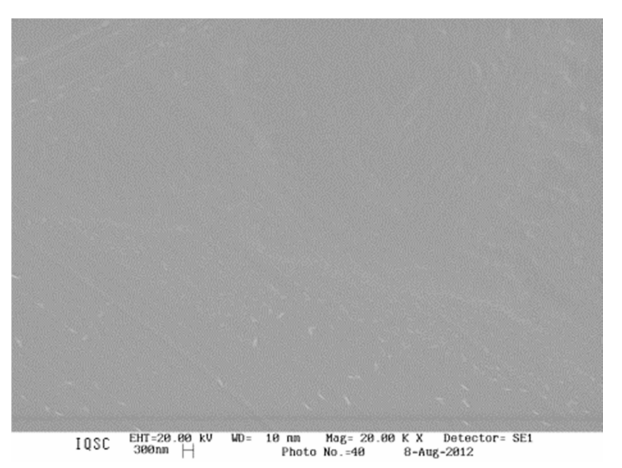

(b)

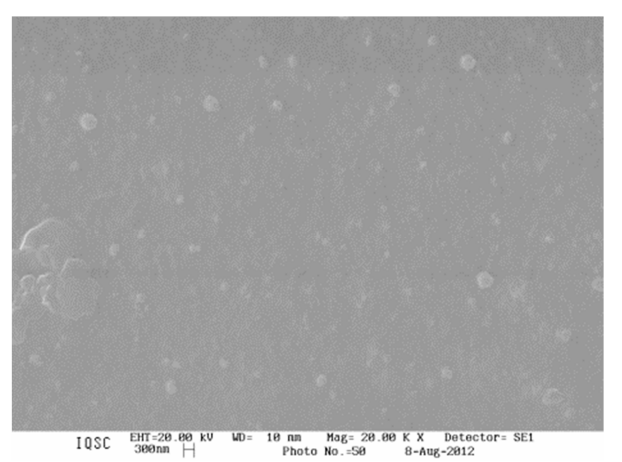

(d)

Figura 79 - MEV de aços carbono 1020 com recobrimentos de PAni com (a) 1 e (b) 3 camadas, e PAni/n-TiO 2 com (c) 1 e (d) 3 camadas.

Estes defeitos na camada de PAni podem ser associados ao estresse produzido durante o tratamento térmico a partir da solução de polímero/NMP e posterior aquecimento, em que o polímero disperso reduz seu volume e novas ligações poliméricas são formadas devido à evaporação do solvente. Shen et al. [114] observaram o efeito do enrugamento de um filme ao se depositar várias camadas ao depositar n- $\mathrm{TiO}_{2}$ sobre aço inoxidável pelo método sol-gel. A semelhança entre os trabalhos é que ambos foram submetidos a temperaturas elevadas para a obtenção do revestimentos final, e as camadas foram depositadas sequencialmente, de forma que a amostra foi submetida ao aquecimento repetidas vezes, assim como, as camadas nela depositadas. Os autores depositaram de 2 a 6 camadas sobre o aço, obtendo um aumento gradual na espessura total do revestimento. Os resultados mostraram que a máxima eficiência foi obtida com 4 camadas (cerca de $460 \mathrm{~nm}$ de espessura), e não com o número máximo de camadas. Com este número de camadas, os autores obtiveram o maior deslocamento (positivo) da resistência de polarização, do potencial (positivo) e da corrente (negativo) de corrosão. A partir de 5 camadas, estes valores revelaram que o sistema era menos protetor do que aquele com 2 camadas. De acordo com os autores, isto ocorreu porque os filmes com mais de 4 camadas apresentaram fraturas, através das quais o íon cloreto encontrou um caminho para chegar à superfície do aço e, assim, provocar maior corrosão, o que se refletiu 
nos resultados eletroquímicos. Estas fraturas ocorreram devido ao estresse gerado no filme pelas sucessivas aplicações de solução NMP/polímero seguida por tratamento térmico, ou seja, múltiplas camadas geraram tensões residuais no filme, direcionadas para cima e para o lado. Além disso, durante a evaporação do solvente formaram-se rachaduras, induzindo a deformação do filme nas regiões próximas à borda. Os filmes de PAni no presente trabalho também apresentaram rugosidade, podendo ainda ter havido rachaduras devido às tensões e, assim como descrito na literatura [115], ocorrido o desprendimento dos filmes nas regiões de borda.

Uma análise da camada de $\mathrm{PAni} / \mathrm{n}-\mathrm{TiO}_{2}$ revela uma superfície rugosa independente do número de camadas adicionadas e que a adição de nanotubos no filme induziu à formação de uma camada uniforme, mas não homogênea, em que os aglomerados de n- $\mathrm{TiO}_{2}$ podem ser observados. Neste caso, a adição de mais camadas não induz defeitos na superfície e não são observadas variações morfológicas do revestimento com diferentes números de camadas. A ausência de defeitos nos revestimentos de $\mathrm{PAni} / \mathrm{n}-\mathrm{TiO}_{2}$ é devido aos aglomerados de n- $\mathrm{TiO}_{2}$ que relaxam o estresse durante o tratamento térmico, agindo como pontos de polimerização. Outro efeito pode ser observado nos filmes de $\mathrm{PAni} / \mathrm{n}-\mathrm{TiO}_{2}$ é a coloração violeta de todos os revestimentos.

De modo geral, todos os revestimentos oferecem algum grau de proteção ao aço, entretanto, o grau de proteção variou com o tipo de revestimento e o número de camadas utilizadas. No caso da PAni, o aumento do número de camadas induziu a uma piora da proteção do aço, podendo este efeito ser associado com presença de canais dentro do filme, que conectam a superfície do aço com o meio agressivo. Estes canais foram desenvolvidos durante o processo de síntese, tal como foi deduzido da caracterização óptica (Fig. 78). Assim, com um revestimento de PAni há uma inibição eficiente da corrosão com a primeira camada, mas quando mais camadas são adicionadas, o efeito de proteção diminui, devido aos defeitos gerados no revestimento que facilitam o contato dos íons cloreto com a superfície do aço. Embora haja uma diminuição no comportamento anticorrosivo, a taxa de corrosão determinada nas multicamadas de PAni é de 2 ordens menor que no aço sem recobrimento, como pode ser encontrado em trabalhos anteriores [59, 149-151]. Nas camadas de PAni/n$\mathrm{TiO}_{2}$ um efeito oposto é encontrado. O aumento no número de camadas diminuiu significativamente o efeito do processo de corrosão. Este efeito está associado com a redução da porosidade pelo aumento do número de camadas (adicionadas camada por camada) do compósito [139]. 
Após os testes eletroquímicos, os revestimentos foram removidos e as superfícies das amostras foram examinadas. Na Fig. 80 são mostradas imagens das amostras após serem submetidas a polarização anódica. A análise dos aços sem os recobrimentos revela que houve um aumento nos processos de corrosão nas amostras que tinham mais de uma camada de PAni. A superfície do aço recoberta com uma camada (Fig. 80a) não apresentou produtos de corrosão. Entretanto, os revestimentos com duas e três camadas revelaram a presença de marcas de corrosão, a qual foi provocada pela presença de canais nos revestimentos (Figs. 80(b,c) e $81(b, c))$.

A superfície do aço com PAni apresenta áreas de corrosão localizadas nas bordas da amostra, o que sugere o início do processo de corrosão em áreas com maior estresse do revestimento. Neste caso, os produtos de corrosão induziram a uma perda de aderência e, portanto, uma redução da durabilidade do mesmo. Entretanto, o revestimento com 3 camadas de $\mathrm{PAni} / \mathrm{n}-\mathrm{TiO}_{2}$ apresentou aumento de aderência após o teste, o qual pode ser associado à redução do estresse na camada polimérica devido aos aglomerados de n- $\mathrm{TiO}_{2}$. A observação da superfície de $\mathrm{PAni} / \mathrm{n}-\mathrm{TiO}_{2}$ também corrobora os resultados anteriores, mostrando um aumento do processo de corrosão por pites quando o número de camadas diminui (Figs. 82(b,c) e 83(b,c)). Pelas imagens de microscopia óptica pode ser observado que a corrosão é maior com o revestimentos de PAni com 2 e 3 camadas (Fig. 81(b,c)) do que quando as amostras são revestidas com o mesmo número de camadas de PAni/n-TiO 2 (Fig. 83(b,c)).

Com relação aos revestimentos multicamadas, Tan et al. [149] observaram que, ao adicionar duas camadas de proteção (uma de PAni e outra de polipirrol), o aço carbono não apresentou vantagens do sistema multicamadas em relação a uma única camada. De fato, se duas camadas gerarem efeitos de tensão resultando em enrugamento ou rachaduras nos filmes, o aço carbono apresentará um resultado ruim com relação à proteção contra a corrosão. Assim, os revestimentos obtidos neste trabalho mostraram-se eficientes pois, as multicamadas praticamente eliminaram a porosidade do filme e o n- $\mathrm{TiO}_{2}$ eliminou o efeito de tensão e rugosidade gerado pela adição de várias camadas. 


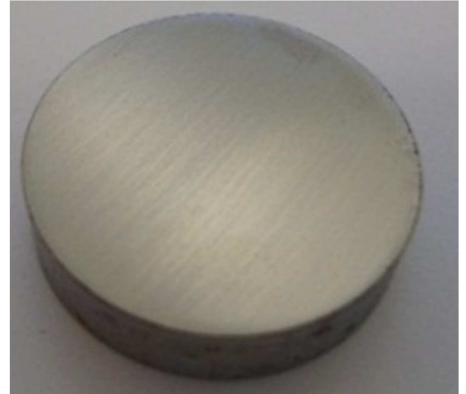

(a)

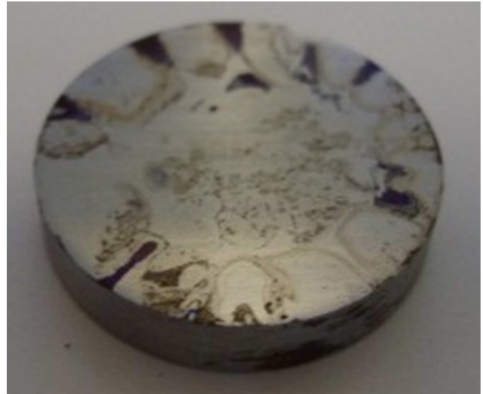

(b)

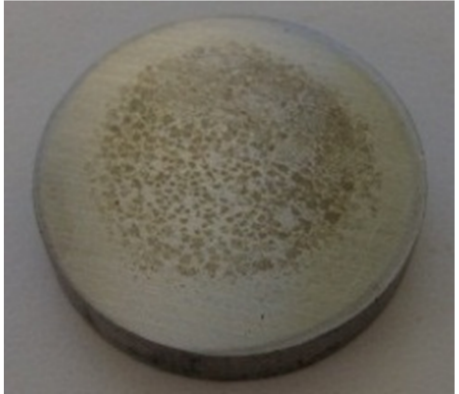

(c)

Figura 80 - Fotos de aços carbono com recobrimentos multicamadas de PAni $25^{\circ} \mathrm{C}$, após ensaio de polarização potenciodinâmica em $\mathrm{NaCl}$ 3,0\% e remoção dos recobrimentos: (a) 1, (b) 2 e (c) 3 camadas.

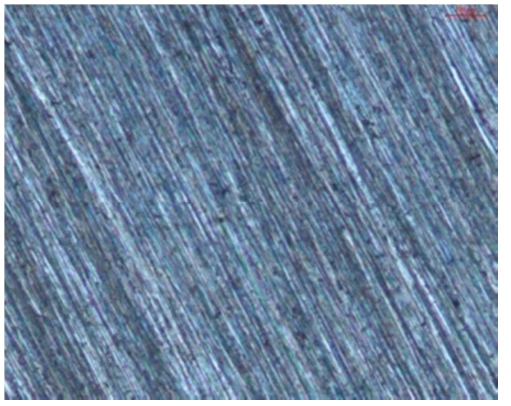

(a)

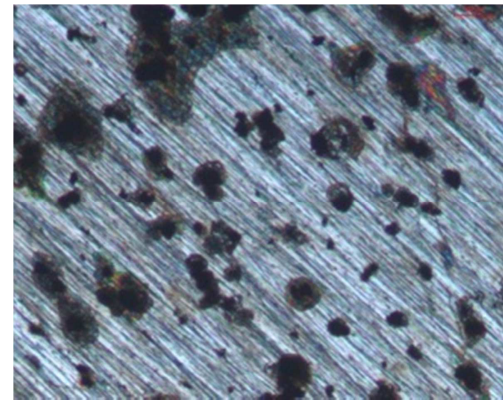

(b)

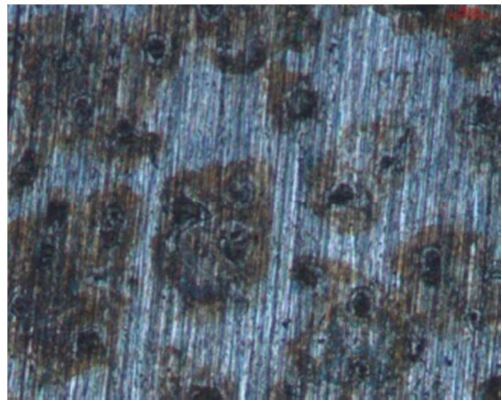

(c)

Figura 81 - Microscopia óptica de aços carbono $1020 \mathrm{com}$ recobrimentos multicamadas de PAni $25^{\circ} \mathrm{C}$, após ensaio de polarização potenciodinâmica em $\mathrm{NaCl}$ 3,0\% e remoção dos recobrimentos: (a) 1, (b) 2 e (c) 3 camadas.

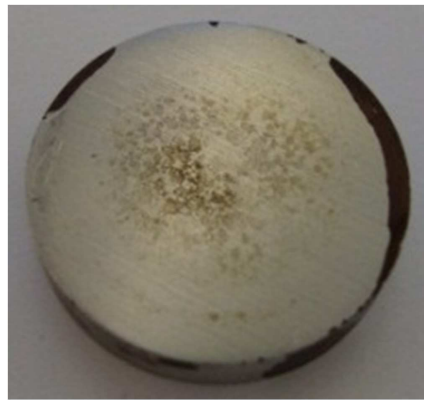

(a)

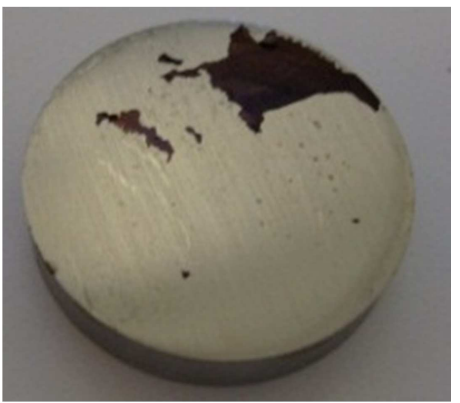

(b)

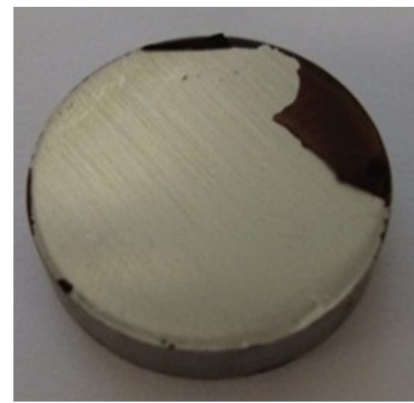

(c)

Figura 82 - Fotos de aços carbono 1020 com recobrimentos multicamadas de $\mathrm{PAni} / \mathrm{n}-\mathrm{TiO}_{2} 25^{\circ} \mathrm{C}$, após ensaio de polarização potenciodinâmica em $\mathrm{NaCl}$ 3,0\% e remoção dos recobrimentos: (a) 1, (b) 2 e (c) 3 camadas. 


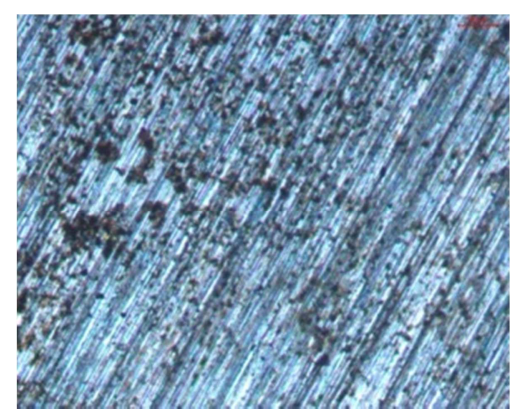

(a)

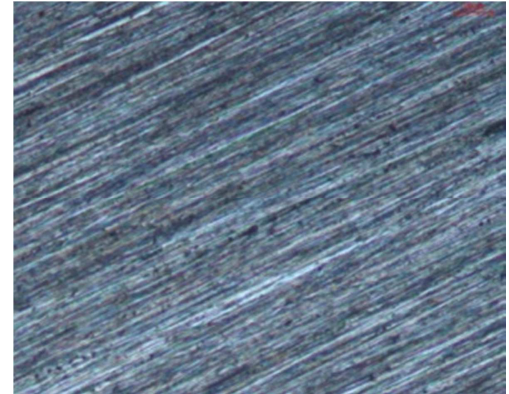

(b)

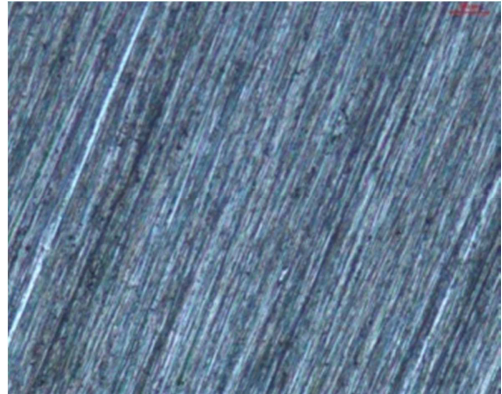

(c)

Figura 83 - Microscopia óptica de aços carbono 1020 com recobrimentos multicamadas de $\mathrm{PAni} / \mathrm{n}-\mathrm{TiO}_{2} 25^{\circ} \mathrm{C}$, após ensaio de polarização potenciodinâmica em $\mathrm{NaCl}$ 3,0\% e remoção dos recobrimentos: (a) 1, (b) 2 e (c) 3 camadas.

Para averiguar a relação entre a quantidade de Ti nos filmes de $\mathrm{PAni} / \mathrm{n}-\mathrm{TiO}_{2}$ com a adição de novas camadas foram realizadas análises de EDX nos filmes de $\mathrm{PAni} / \mathrm{n}-\mathrm{TiO}_{2}$ com 1 e 3 camadas. Os resultados (Fig. 84, Tabela 17) mostram que a quantidade de Ti não varia significativamente em amostras com 1 e 3 camadas de $\mathrm{PAni} / \mathrm{n}-\mathrm{TiO}_{2}$, indicando que, após a deposição de uma camada, não ocorre qualquer tipo de deslocamento do Ti para outras camadas (difusão, ou outro efeito provocado por influência da temperatura decorrente da deposição das camadas subsequentes).

Assim, o aumento da proteção da superfície ocorre unicamente por aumento da espessura do revestimento e da diminuição de sua porosidade. Além disto, a menor quantidade de Ti encontrada no filme em comparação ao conteúdo no polímero em pó (Fig. 65, Tabela 13) pode ser decorrente de uma reordenação das cadeias poliméricas sobre o óxido e efeito do solvente que não se evapora, com consequente plastificação da superfície e mascaramento da quantidade de Ti na análise. Entretanto, deve ser ressaltado que esta análise é apenas superficial, não correspondendo à quantidade total de Ti no interior das camadas.

Outro ponto importante é verificar se a distribuição de n- $\mathrm{TiO}_{2}$ sobre o filme de PAni ocorre de forma homogênea ou não. Por mapeamento por EDX, utilizando amostra com 3 camadas de $\mathrm{PAni} / \mathrm{n}-\mathrm{TiO}_{2} 25^{\circ} \mathrm{C}$ foi observado, com aumento de $500 \mathrm{x}$, que a distribuição do Ti é perfeitamente homogênea sobre o filme (Fig. 85). Aumentando a ampliação para 3000x, podem ser observadas heterogeneidades na distribuição do Ti, com a formação eventual de aglomerados (Fig. 86). 


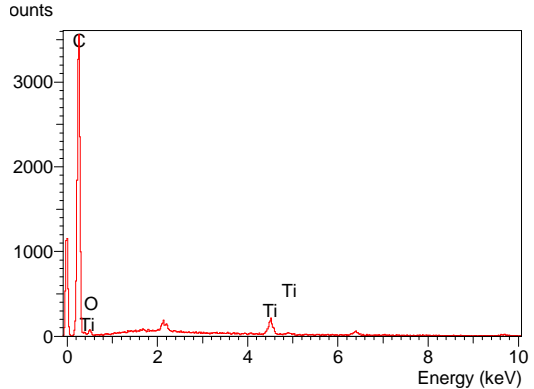

(a)

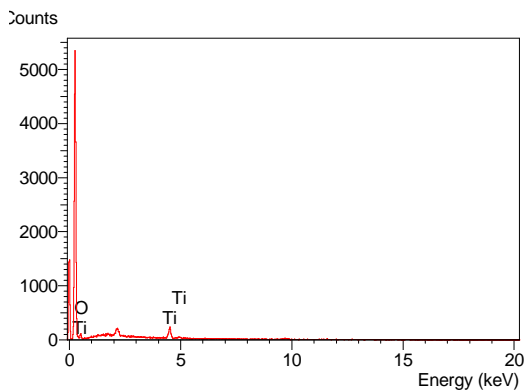

(b)

Figura 84 - Análise de EDX da composição química de filme de $\mathrm{PAni} / \mathrm{n}-\mathrm{TiO}_{2} 25^{\circ} \mathrm{C}$ sobre aço carbono 1020 com: (a) 1 e (b) 3 camadas.

Tabela 16 - Composição química de filme de PAni/n- $\mathrm{TiO}_{2} 25^{\circ} \mathrm{C}$ sobre aço carbono 1020 , obtida por EDX (Fig. 84)

\begin{tabular}{|cccc|}
\cline { 2 - 4 } \multicolumn{1}{c|}{} & \multicolumn{3}{c|}{ \% do elemento } \\
\hline & $\mathbf{C}$ & $\mathbf{O}$ & $\mathbf{T i}$ \\
\hline $\mathbf{1}$ camada & 82,05 & 13,61 & 4,34 \\
\hline 3 camadas & 82,38 & 14,09 & 3,53 \\
\hline
\end{tabular}

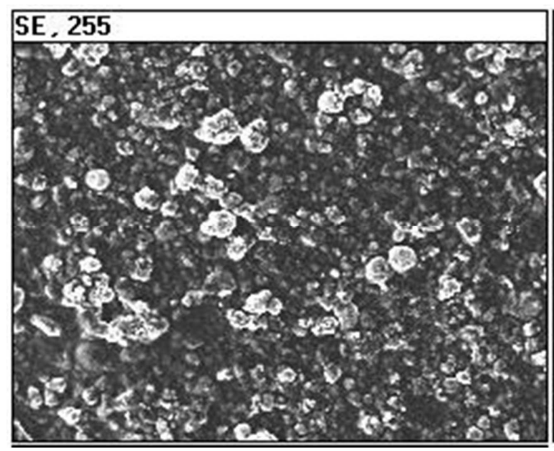

(a)

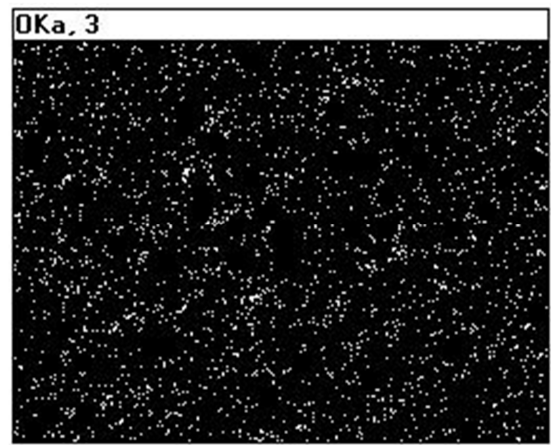

(c)

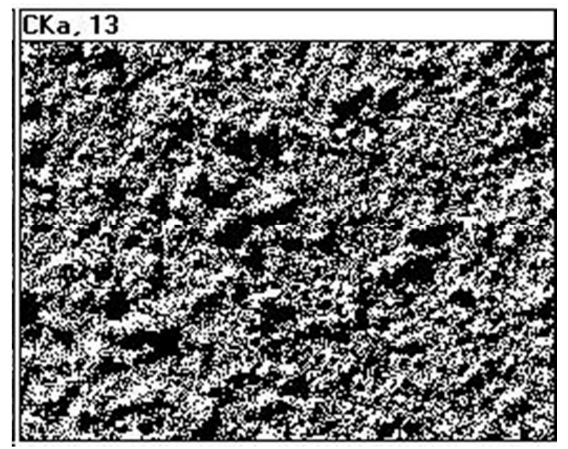

(b)

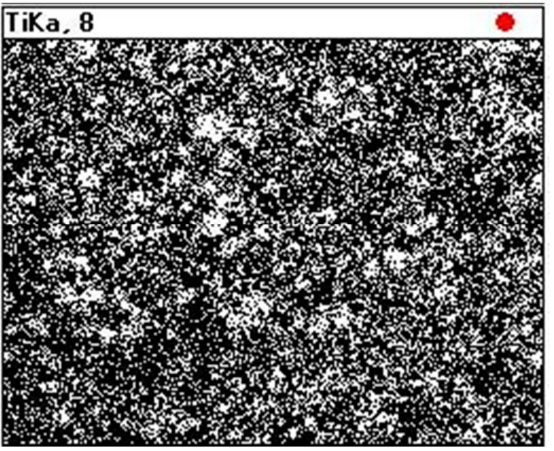

(d)

Figura 85 - Análise de EDX em filme de PAni/n- $\mathrm{TiO}_{2} 3$ camadas para fazer mapeamento da distribuição de elementos químicos, a partir de imagem de MEV com menor ampliação (magnificação: 500x) (a). Elementos mapeados: (b) C, (c) O e (d) Ti. 


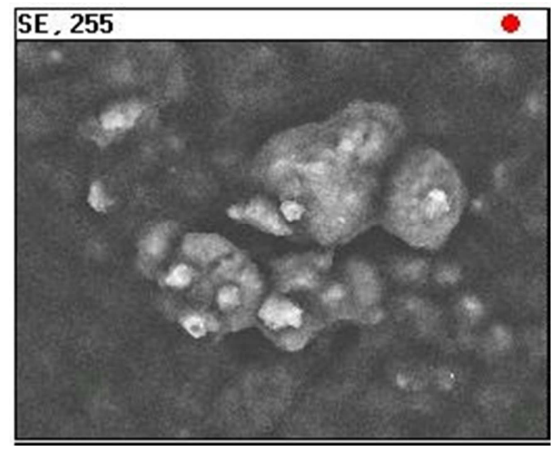

(a)

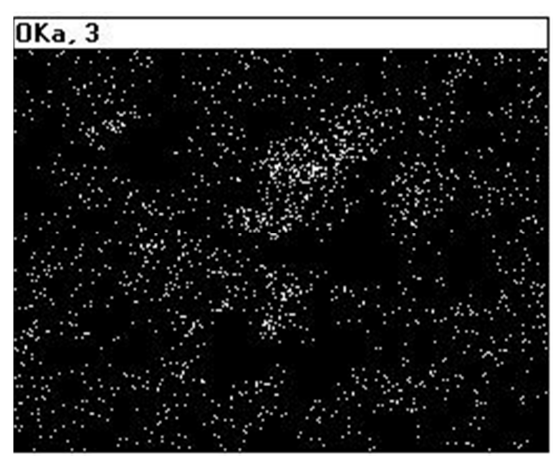

(c)

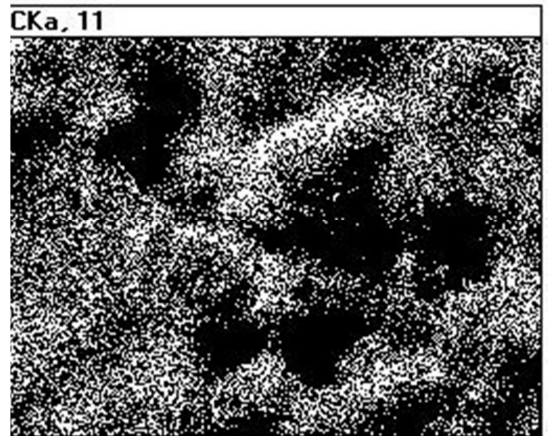

(b)

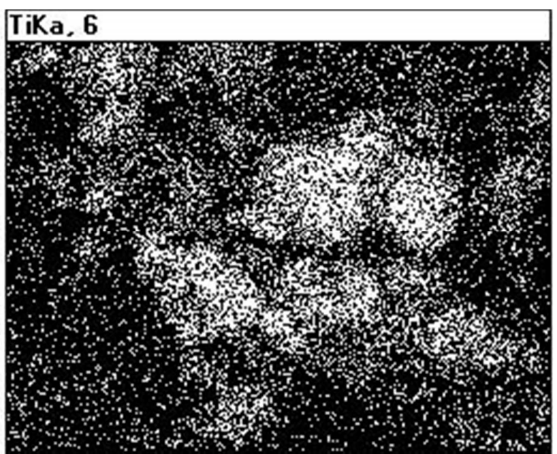

(d)

Figura 86 - Análise de EDX em filme de PAni/n- $\mathrm{TiO}_{2} 3$ camadas para fazer mapeamento da distribuição de elementos químicos, a partir de imagem de MEV com maior ampliação (magnificação: 3000x) (a). Elementos mapeados: (b) C, (c) $\mathrm{O}$ e (d) Ti.

\subsubsection{Ensaios de névoa salina e testes de aderência de $\mathbf{P A n i} / \mathbf{n}-\mathrm{TiO}_{2}$}

As análises feitas até esta etapa mostraram que, de forma geral, os revestimentos com melhores desempenhos foram aqueles sintetizados a $25{ }^{\circ} \mathrm{C}$. O revestimento de PAni com 1 camada exibiu uma excelente proteção contra a corrosão do aço carbono. Revestimentos de $\mathrm{PAni} / \mathrm{n}-\mathrm{TiO}_{2}$ foram eficientes somente com mais de uma camada, particularmente com 3 camadas. Entretanto, do ponto de vista de economia não se justifica a adição de 3 camadas de PAni/n- $\mathrm{TiO}_{2}$ se com 1 camada de PAni já se consegue uma proteção comparável, senão melhor. Contudo, os testes realizados até o momento mostraram que esta afirmação é verdade para ensaios de polarização potenciodinâmicas. Um ensaio de corrosão acelerado pode, entretanto, indicar por quanto tempo um revestimento permanece aderido a seu substrato. Deste ponto de vista, este ensaio é muito interessante para verificar a diferença na aderência entre o filme de PAni e de $\mathrm{PAni} / \mathrm{n}-\mathrm{TiO}_{2}$, o que não é totalmente verificado por uma análise de polarização potenciodinâmica. Assim, um ensaio de corrosão acelerada em câmara de névoa salina foi feito nas amostras de PAni e PAni/n- $\mathrm{TiO}_{2}$ com 1 camada, a fim de comparar suas aderências ao substrato de aço. 


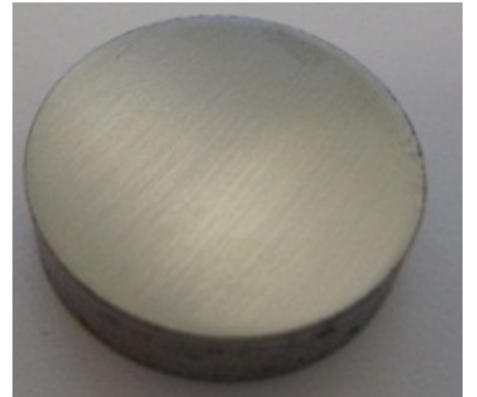

(a)

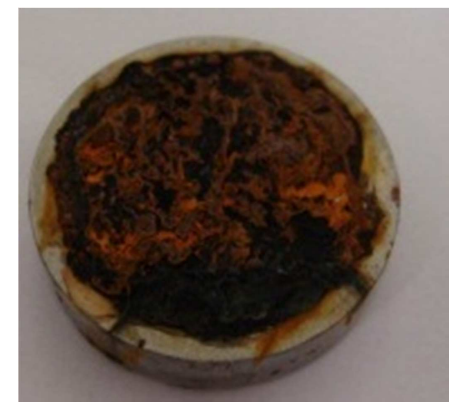

(d)

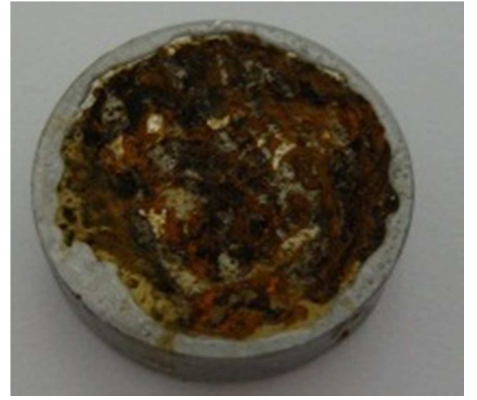

(b)

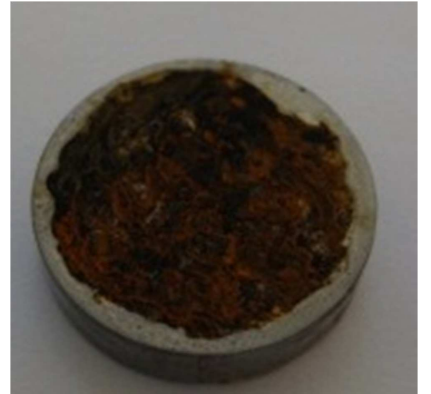

(c)

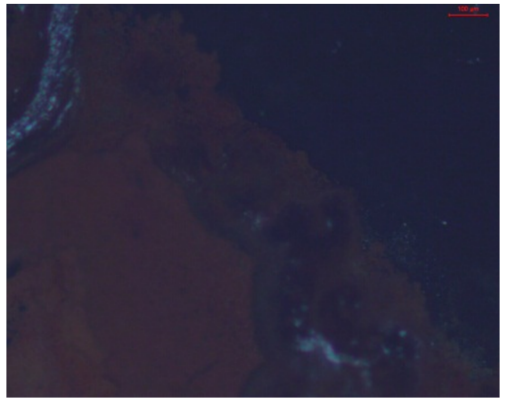

(e)

Figura 87 - Fotos de aço carbono 1020 sem recobrimento submetido a ensaio em camada de névoa salina após: (a) 0, (b) 3, (c) 6h e (d) 48h. Microscopia óptica da (e) superfície após remoção do filme.

Os resultados mostraram que o revestimento de PAni/n- $\mathrm{TiO}_{2}$ (Fig. 89) apresentou um desempenho muito superior ao recobrimento de PAni (Fig. 88), levando 48h para se desprender da superfície, enquanto o recobrimento de PAni permaneceu aderido por somente 6h. Pela figura 88 , se observa que após $3 \mathrm{~h}$ em câmara de névoa salina, o filme já havia iniciado seu desprendimento; uma vez que existe um caminho para a entrada da névoa, a corrosão será mais intensa pela formação de ferrugem. Pelas imagens de microscopia óptica dos filmes após a análise, observa-se que nenhum dos recobrimentos sofreu degradação apreciável dentro do grau de ampliação observado. O aço sem recobrimento, por outro lado, já se apresentou totalmente corroído após 3h na câmara (Fig. 87).

Assim, conclui-se desta etapa que o $\mathrm{n}-\mathrm{TiO}_{2}$, embora aumente a porosidade do filme, apresenta uma grande contribuição na aderência do revestimento ao substrato metálico; uma vez que os filmes de PAni apresentaram resistência ao meio corrosivo, não sofrendo degradação, o $\mathrm{TiO}_{2}$ colaborou no sentido de manter este filme aderido ao substrato por um tempo maior do que quando somente o polímero foi depositado sobre a PAni. 


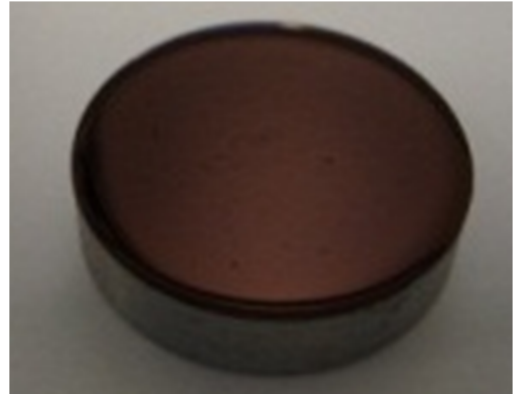

(a)

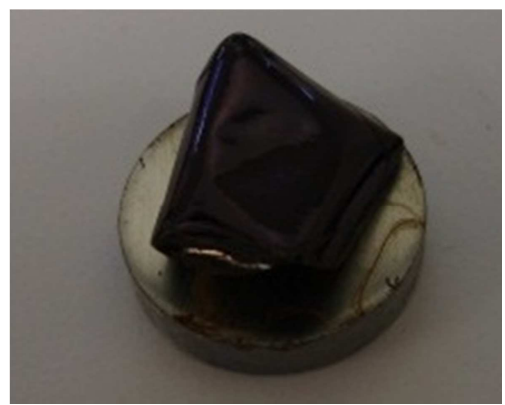

(c)

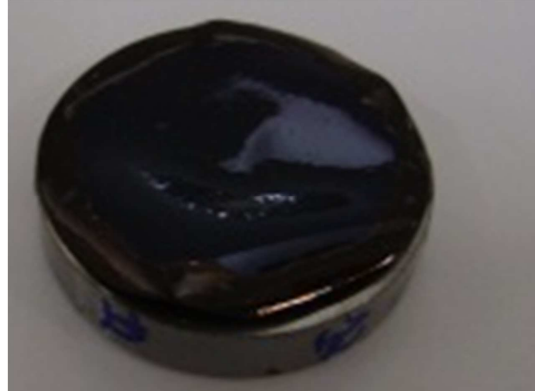

(b)

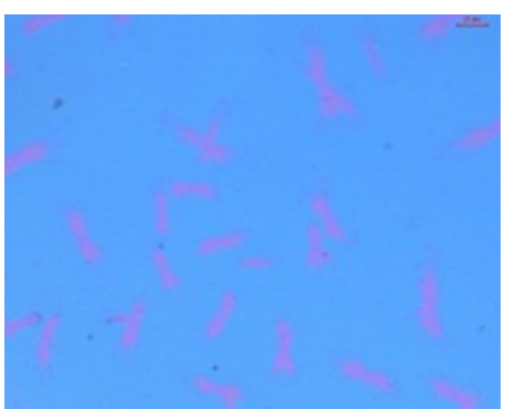

(d)

Figura 88 - Fotos de aço com uma camada de PAni $25^{\circ} \mathrm{C}$ submetido a ensaio em camada de névoa salina após: (a) 0 , (b) 3 e (c) 6h. Microscopias ópticas do (d) revestimento após finalização do ensaio e (e) da superfície após remoção do filme.

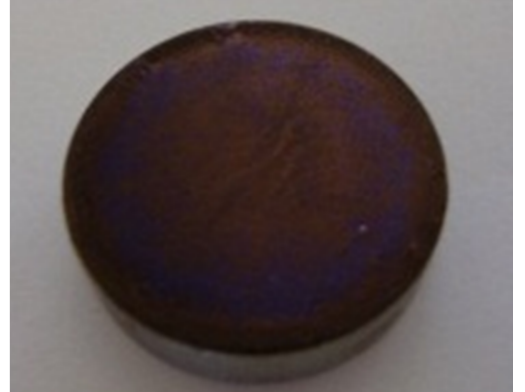

(a)

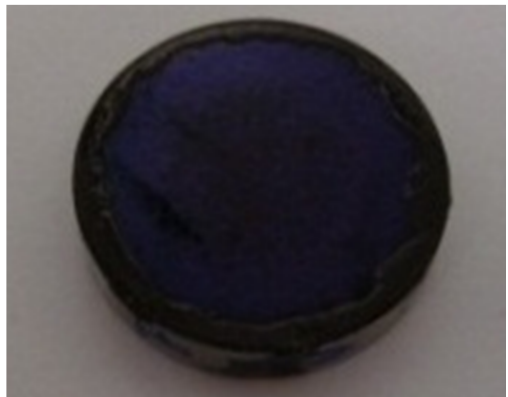

(d)

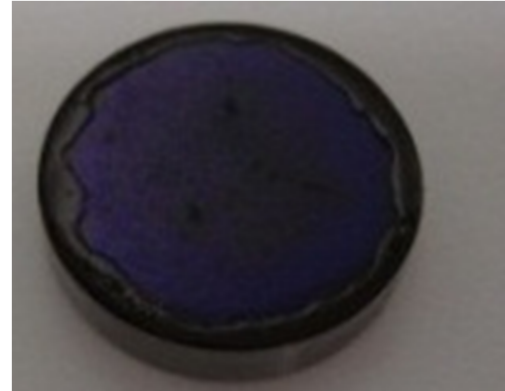

(b)

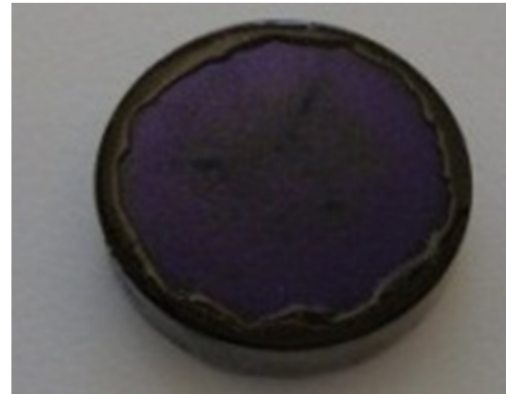

(c)

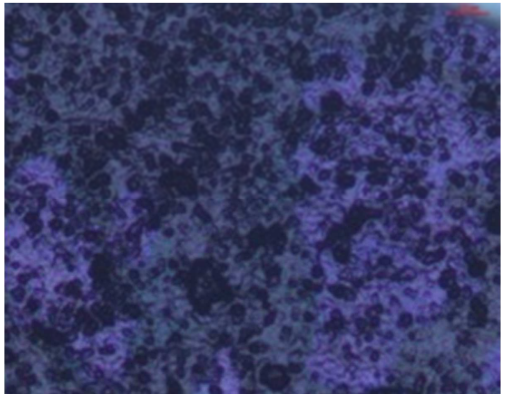

(e)

Figura 89 - Fotos de aço com uma camada de $\mathrm{PAni} / \mathrm{n}-\mathrm{TiO}_{2} 25^{\circ} \mathrm{C}$ submetido a ensaio em camada de névoa salina após: (a) 0, (b) 3, (c) 6 e (d) 48 h. Microscopias ópticas do (e) revestimento após finalização do ensaio e (f) da superfície após remoção do filme. 


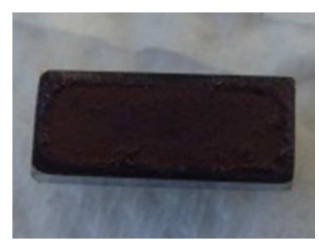

(a)

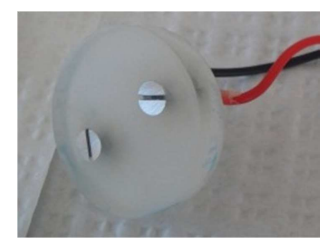

(b)

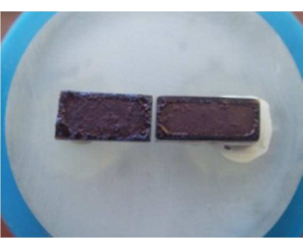

(c)

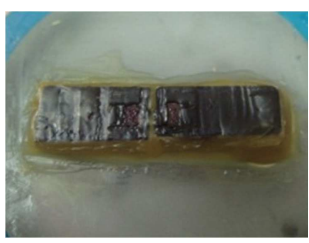

(d)

Figura 90 - Montagem experimental da amostra de aço carbono 1020 com solda, e recoberto com 3 camadas de $\mathrm{PAni} / \mathrm{n}-\mathrm{TiO}_{2}$ em resina, para análise por TEVV.

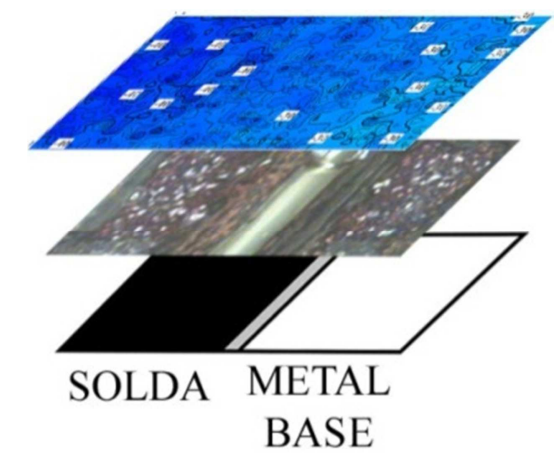

(a)

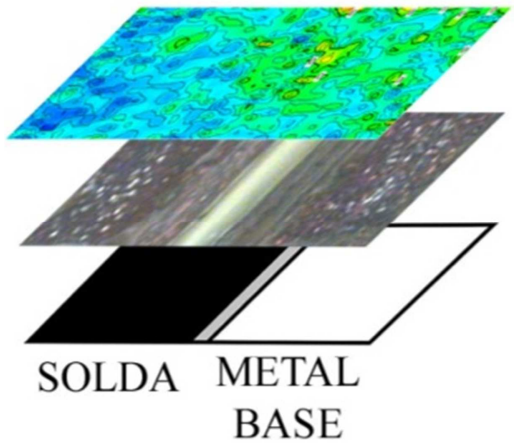

(c)

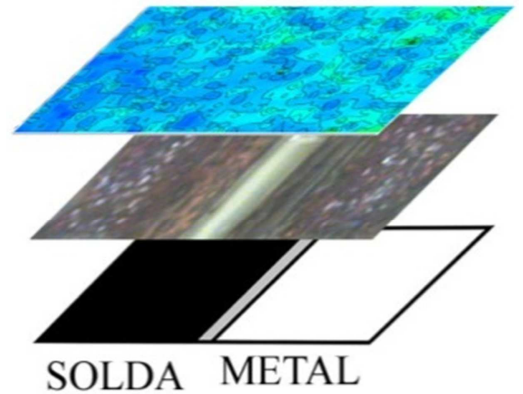

BASE

(b)

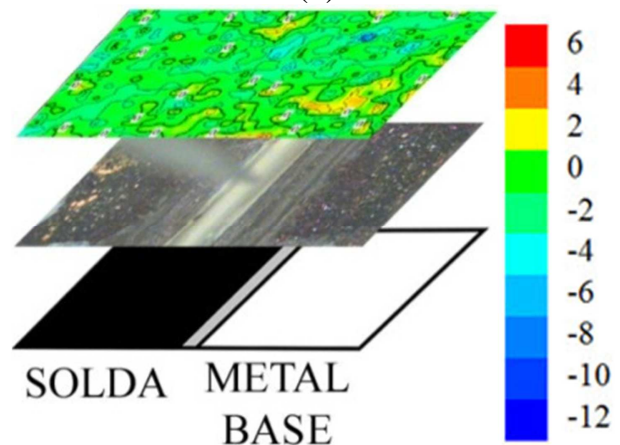

(d)

Figura 91 - Análises pela TEVV e microscopia óptica de solda de aço 1020 revestido com PAni/n- $\mathrm{TiO}_{2}$, com 3

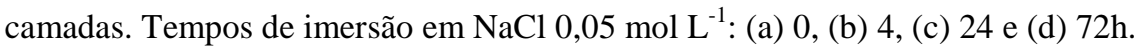

\subsubsection{Aplicação de 3 camadas de $\mathrm{PAni} / \mathrm{n}-\mathrm{TiO}_{2}$ em solda de aço carbono}

Uma vez otimizadas as condições de síntese de $\mathrm{PAni} / \mathrm{n}-\mathrm{TiO}_{2}$, o material foi utilizado como revestimento de uma superfície de aço 1020 submetida a um processo de solda TIG. O revestimento foi avaliado por ensaios de TEVV combinado com microscopia óptica, sendo a montagem experimental utilizada diferente das análises com esta técnica realizadas no mesmo aço sem recobrimento. Como o solvente n-metil-pirrolidona (NMP) sob temperatura elevada ataca a resina, as amostras de solda e de material base foram cortadas, recobertas com o polímero e só depois coladas (com cola de prata) sobre a cabeça de um parafuso já embutido na resina. 
Após a secagem da cola, a região de análise foi limitada utilizando cera de abelha (Fig. 90) e as análises foram realizadas em solução de $\mathrm{NaCl} 0,05 \mathrm{~mol} \mathrm{~L}^{-1}$; os eletrodos permaneceram todo o tempo eletricamente conectados. Pela Fig. 91 pode ser observado que tanto na região de solda quanto no metal base não são observadas áreas anódicas, indicando que até $72 \mathrm{~h}$ de imersão não é observada corrosão. Os mapas bidimensionais de TEVV indicam que inicialmente o filme tem comportamento catódico (Fig. 91a), mantendo-se assim até 4 h de imersão (Fig. 91b). Após 24 h de imersão (Fig. 91c), este comportamento começa a se alterar e o revestimento passa a apresentar caráter isolante. Após 72 h de imersão ainda não é observado o aparecimento de zonas anódicas (Fig. 91d). Por estes resultados, pode-se concluir que o revestimento contendo 3 camadas de $\mathrm{PAni} / \mathrm{n}-\mathrm{TiO}_{2}$ foi eficiente para inibir a corrosão, tanto nas solda como no metal base, nas condições utilizadas na análise.

\subsubsection{Considerações parciais}

Os resultados obtidos permitem concluir que um revestimento a base de $\mathrm{PAni} / \mathrm{n}-\mathrm{TiO}_{2}$ sintetizado em meio de $\mathrm{H}_{2} \mathrm{SO}_{4}$ a $25^{\circ} \mathrm{C}$ tem propriedades protetoras contra a corrosão de aço 1020. O revestimento da superfície com PAni $25^{\circ} \mathrm{C}$ apresentou inicialmente excelentes propriedades anticorrosivas devido à sua notável homogeneidade. Neste ponto, os revestimentos de $\mathrm{PAni} / \mathrm{n}-\mathrm{TiO}_{2}$ apresentaram a desvantagem de alta porosidade e, devido a esta característica, um desempenho inferior na proteção contra a corrosão. Esta característica foi compensada pela adição de multicamadas de $\mathrm{PAni} / \mathrm{n}-\mathrm{TiO}_{2}$, o que praticamente eliminou o efeito da porosidade. Por outro lado, a adição de várias camadas de PAni provocou enrugamento do filme devido às tensões provocadas pelo tratamento térmico, sendo que no caso do revestimento de $\mathrm{PAni} / \mathrm{n}-\mathrm{TiO}_{2}$, a presença do óxido inibiu a formação destas tensões. Testes em câmara de névoa salina mostraram que o n- $\mathrm{TiO}_{2}$ apresenta uma grande contribuição para aumento de aderência do revestimento com relação à PAni. A aplicação deste revestimento sobre solda de aço 1020 foi eficiente para protegê-lo contra a corrosão durante as primeiras $72 \mathrm{~h}$ em solução de $\mathrm{NaCl}$. 


\section{CAPÍTULO IV}

\section{CONCLUSÕES}

Por meio do estudo da corrosão em soldas TIG dos aços inoxidáveis 304 e 316, e do aço carbono 1020, por diferentes sistemas de análise de corrosão, seguida da síntese e caracterização de revestimento protetor de $\mathrm{PAni} / \mathrm{n}-\mathrm{TiO}_{2}$ contra a corrosão do aço carbono 1020, as seguintes conclusões puderam ser tecidas:

As alterações estruturais causadas pela aplicação de solda TIG (sem alteração da composição química do aço) foram suficientes para causar diferentes comportamentos quanto à corrosão dos aços inoxidáveis 304 e 316, e do aço carbono 1020 em meio de cloreto.

$\checkmark$ Nos aços inoxidáveis 304 e 316, a aplicação de solda resultou em alteração da estrutura austenística para ferrítica; como resultado, a região de solda apresentou menor corrosão que seu metal base, sendo assim caracterizado como uma região catódica, enquanto o metal base, como uma região anódica. $\mathrm{O}$ aumento da corrente de solda intensificou ainda mais este efeito.

No aço carbono 1020, a aplicação do mesmo tipo de solda alterou a estrutura, de ferrítica e cementita para perlita; experimentalmente foi demonstrado que a solda é mais susceptível à corrosão que o metal base, sendo a solda uma região anódica, e o metal base, uma região catódica.

$\checkmark$ A análise eletroquímica de corrosão nos aços inoxidáveis pôde ser feita com sucesso por um dispositivo eletroquímico miniaturizado, denominado sensor pontual de corrosão (SPC), o qual apresentou vantagens como pequena área de análise, baixo gasto de reagente e portabilidade, permitindo análises em campo.

Revestimento de polianilina foi suficiente para proteger a superfície dos aços inoxidáveis e suas soldas contra a corrosão (por ensaios de polarização potenciodinâmica).

Ensaios de corrosão localizados (EIEL, TEVV) corroboraram com ensaios de corrosão globais (EIE, PCA) para demonstrar a maior suscetibilidade da corrosão da região de solda do 
aço carbono 1020 e, além disso, da formação de um par galvânico entre a região de solda (ânodo) e do metal base (cátodo).

$\checkmark$ Revestimentos protetores de $\mathrm{PAni} / \mathrm{n}-\mathrm{TiO}_{2}$ apresentaram bom desempenho em proteger aço carbono 1020 contra a corrosão; melhores condições de síntese foram obtidas em meio de $\mathrm{H}_{2} \mathrm{SO}_{4}$, à temperatura de $25^{\circ} \mathrm{C}$ e utilizando o polímero desdopado.

$\checkmark \mathrm{O}$ uso de multicamadas do revestimento de $\mathrm{PAni} / \mathrm{n}-\mathrm{TiO}_{2}$ foi útil em diminuir a porosidade do filme, melhorando a eficiência do revestimento. No caso da PAni, as multicamadas provocaram enrugamento do revestimento devido às tensões provocadas pelo tratamento térmico a que o polímero ficou sujeito; adicionalmente, os nanotubos de $\mathrm{TiO}_{2}$ aumentaram a aderência do revestimento ao aço.

Revestimento de PAni/n- $\mathrm{TiO}_{2}$, com 3 camadas, foi eficiente em proteger região de solda de aço carbono 1020 contra a corrosão. 


\section{CONCLUSIONS}

Through the study of corrosion in TIG welding in 304 and 316 stainless steels, and 1020 carbon steel, by different corrosion analysis systems, followed by the synthesis and characterization of $\mathrm{PAni} / \mathrm{n}-\mathrm{TiO} 2$ protector coating against corrosion of the 1020 carbon steel, the following conclusions could be woven:

The structural changes caused by the application of TIG welding (without changing the chemical composition of the steel) were sufficient to cause different behaviours for corrosion of 304 and 316 stainless steels, and 1020 carbon steel in chloride medium.

$\checkmark$ In the 304 and 316 stainless steels, the application of TIG welding has resulted in changes of the structure austenistic to ferritic; as a result, the weld area showed less corrosion than their base metal, thus characterized as a cathode region, while the metal base as an anode region. The increase in welding current further increased this effect.

$\checkmark$ In the 1020 carbon steel, the application of the same type of weld has changed its structure of ferrite and cementite to pearlite; it was experimentally demonstrated that welding is more susceptible to corrosion than the base metal, and welding is an anodic area and the base metal, a cathodic one.

The corrosion electrochemical analysis in the stainless steels could be done successfully by a miniaturized electrochemical device called corrosion punctual sensor (CPS), which shows advantages such as small area of analysis, low reagent cost and portability, allowing field analysis.

$\checkmark$ Polyaniline coating was sufficient to protect the surface of stainless steels and their welds from corrosion (by potentiodynamic polarization measurements).

Localized corrosion tests (LEIS, SVET) corroborate overall global corrosion tests (EIS, OCP) to demonstrate the greater corrosion susceptibility of the weld area of 1020 carbon steel and, in addition, the formation of a galvanic couple between the welding region (anode) and the base metal (cathode). 
$\checkmark \mathrm{PAni} / \mathrm{n}-\mathrm{TiO}_{2}$ protective coatings has presented good performance in protecting 1020 carbon steel against corrosion; better synthesis conditions were obtained using $\mathrm{H} 2 \mathrm{SO} 4$ as reaction medium, at $25^{\circ} \mathrm{C}$ and using dedoped polymer.

$\checkmark$ The use of multilayers coating of $\mathrm{PAni} / \mathrm{n}-\mathrm{TiO}_{2}$ helpful in reducing the porosity of the film, improving the efficiency of coating. In the case of PAni, the multilayer coatings caused the wrinkling due to stress caused by heat treatment of the polymer was subject; additionally, $\mathrm{TiO}_{2}$ nanotubes increased adhesion of the coating to steel.

$\checkmark$ Three layers of PAni/n-TiO 2 coating were effective in protecting the weld region against corrosion processes in the 1020 carbon steel. 


\section{CONCLUSIONES}

Por medio de los estudios de la corrosión en soldaduras TIG de los aceros inoxidables 304 y 316, y del acero al carbono 1020, por diferentes dispositivos de análisis de corrosión, seguida por la síntesis y caracterización de revestimiento protector de $\mathrm{PAni} / \mathrm{n}-\mathrm{TiO}_{2}$ contra la corrosión del acero al carbono 1020, las siguientes conclusiones fueran obtenidas:

$\checkmark$ Las alteraciones estructurales provocadas por la aplicación de soldadura TIG (sin alteración de la composición química del acero) fueran suficientes para causar diferentes comportamientos con respecto a la corrosión de los aceros inoxidables 304 y 316, y del acero al carbono 1020, en medio de cloruro;

$\checkmark$ En los aceros inoxidables 304 y 316, la aplicación de soldadura ha resultado en un cambio de la estructura austenística para la ferritica; como resultado, la región de soldadura ha presentado menos corrosión que su metal base, se constituyendo así una región catódica, mientras el metal base, una región anódica. El incremento de la corriente de soldadura ha intensificado más aún este efecto.

$\checkmark$ En el acero al carbono 1020, la aplicación del mismo tipo de soldadura cambió la estructura cristalina, de ferrítica y cementita, para perlita; experimentalmente fue demostrado que la soldadura es más susceptible a la corrosión que su metal base, siendo la soldadura la región anódica, y el metal base, la región catódica.

$\checkmark$ El análisis electroquímico de corrosión en los aceros inoxidables fue hecho con suceso por un dispositivo electroquímico miniaturizado, llamado sensor puntual de corrosión (SPC), el que ha presentado ventajas como pequeña área de análisis, bajo gasto de reactantes y portabilidad, permitiendo análisis en campo.

$\checkmark$ Revestimiento de polianilina fue suficiente para proteger la superficie de los aceros inioxidables y sus soldaduras contra la corrosión (por ensayos de polarización potenciodinamica);

$\checkmark$ Ensayos de corrosión localizados (EIEL, TEVV) corroboraran con ensayos de corrosión globales (EIE, PCA) para demostrar la mayor susceptibilidad de la corrosión de la región de soldadura del acero al carbono 1020; además, la formación de un par galvánico entre la región de soldadura (ánodo) e del metal base (cátodo); 
$\checkmark$ Revestimientos protectores de $\mathrm{PAni} / \mathrm{n}-\mathrm{TiO}_{2}$ presentaran buen desempeño en proteger al acero al carbono 1020 contra la corrosión; mejores condiciones de síntesis fueran obtenidas en medio de $\mathrm{H}_{2} \mathrm{SO}_{4}$, a la temperatura de $25^{\circ} \mathrm{C}$ y utilizando el polímero desdopado;

$\checkmark$ El uso de multicapas del revestimiento de $\mathrm{PAni} / \mathrm{n}-\mathrm{TiO}_{2}$ fue útil en disminuyere la porosidad de la película, mejorando la eficiencia del revestimiento. En el caso de la PAni, las multicapas provocaran la corrugación del revestimiento debido a las tensiones provocadas por el tratamiento térmico a que el polímero estuvo expuesto; adicionalmente, los nanotubos de $\mathrm{TiO}_{2}$ han aumentado la adherencia del revestimiento al acero

$\checkmark$ Revestimiento de $\mathrm{PAni} / \mathrm{n}-\mathrm{TiO}_{2}$ con 3 capas, fueran suficientes en proteger la región de soldadura del acero al carbono 1020 contra la corrosión. 


\section{Trabalhos Futuros}

Análise da corrosão na zona afetada pelo calor (ZAC) em relação à região de solda e do metal base nos aços 304, 316 e 1020, utilizando o SPC e análises pela TEVV e EIEL.

Estudo da variação da quantidade de $\mathrm{TiO}_{2}$ no compósito Pani/n- $-\mathrm{TiO}_{2}$.

Análise da eficiência do revestimento de PAni/n- $\mathrm{TiO}_{2}$ em ausência total de luz, e sob radiação UV.

Uso de matrizes para dispersar PAni/n- $\mathrm{TiO}_{2}$ no estado dopado e utilizá-lo como "revestimento protetor inteligente" contra a corrosão: smart coatings.

Síntese de PAni/n- $\mathrm{TiO}_{2}$ em meios de oxalato e fosfato como formas de aumentar a aderência do filme.

Deposição de mais de três camadas de PAni e PAni/n- $\mathrm{TiO}_{2}$ sobre aço 1020: análise do limite de camadas que exerce proteção sobre o aço.

Análise de aço com revestimentos de PAni para análise pela TEVV: montagem de um sistema experimental que ofereça maior reprodutibilidade. 


\section{Referências Bibliográficas}

[1] INSTITUTE OF CORROSION. Estimativa de gastos com corrosão em países desenvolvidos. Northampton, 2013. Disponível em: <http://www.icorr.org>. Acesso em: 24 jan. 2013.

[2] JONES, D. A. Principles and prevention of corrosion. New York: McMillan, 1992. $568 \mathrm{p}$.

[3] GENTIL, V. Corrosão. Rio de Janeiro: Livros Técnicos e Científicos, 2011. 360p.

[4] FONTANA, M. G. Corrosion engineering. New York: McGraw-Hill, 1986. 556p.

[5] SILVA, P. F. D. Corrosão e monitoramento em fundações metálicas. Belo Horizonte: Vértice Engenharia, 2008. 306p.

[6] INSTITUTO DE METAIS NÃO-FERROSOS. Formas de corrosão: desenho esquemático. São Paulo, 2013. Disponível em: 〈http://www.icz.org.br/portaldagalvanizacao〉. Acesso em: 02 maio 2013.

[7] MARCUS, P. Corrosion mechanism in theory and practice. New York: Marcel Dekker, 1995. 641p.

[8] SCULLY, J. C. The fundamentals of corrosion. New York: Pergamon Press, 1990. 226p.

[9] SZKLARSKA-SMIALOWSKA, Z. Pitting corrosion of metals. Houston: National Association of Corrosion Engineers, 1986. 431p.

[10] MACHADO, I. G. Soldagem e técnicas conexas: processos. Porto Alegre: Universidade Federal do Rio Grande do Sul, 1996. 478p.

[11] BIKERMAN, J. J. The science of adhesive joints. New York: Academic Press, 1961. 258p.

[12] WAINER, E. Soldagem: processos e metalurgia. São Paulo: Edgard Blücher, 2004. 494p.

[13] ENGINEERING - costs, quality, and safety. In: WELDING handbook. Miami: American Welding Society, 1984. p. 12-13.

[14] KOU, S. Welding metallurgy. Hoboken: Wiley-Interscience, 2003. 461p. 
[15] DAVIES, A. C. The science and practice of welding. London: Cambridge University Press, 1972. 590p.

[16] E-AGPS. Noções de estrutura cristalina. São Paulo, 2013. Disponível em: <http://www.e-agps.info/angelus/cap1/subcubicas.htm>. Acesso em: 01 maio 2013.

[17] SILVA, P. F. Introdução à corrosão e proteção das superfícieis metálicas. Belo Horizonte: Univ Fed de Minas Gerais, 1981. 355p.

[18] DELINDER, L. S.; BRASUNAS, A. S. (Ed.). Corrosion basics: an introduction. Houston: National Association of Corrosion Engineers, 1984. 353 p.

[19] DIEBOLD, U. The surface science of titanium dioxide. Surface Science Reports, v. 48, n. 5-8, p. 53-229, 2003.

[20] LANDOLT, D. Corrosion and surface chemistry of metals. Lausanne: EPFL Press, 2007. 622p.

[21] FAEZ, R.; REIS, C.; FREITAS, P. S.; KOSIMA, O. K.; RUGGERI, G.; PAOLI, M. A. Polímeros condutores. Química nova na escola, n. 11, p. 13-18, 2000.

[22] HUANG, W. S.; HUMPHREY, B. D.; MACDIARMID, A. G. Polyaniline, a novel conducting polymer - morphology and chemistry of its oxidation and reduction in aqueouselectrolytes. Journal of the Chemical Society-Faraday Transactions I, v. 82, n. 8, p. 23852400, 1986.

[23] MACDIARMID, A. G.; CHIANG, J. C.; RICHTER, A. F.; EPSTEIN, A. J. Polyaniline a new concept in conducting polymers. Synthetic Metals, v. 18, n. 1-3, p. 285-290, 1987.

[24] MACDIARMID, A. G.; EPSTEIN, A. J. Secondary doping - a new concept in conducting polymers. Macromolecular Symposia, v. 98, n. 1, p. 835-842, 1995.

[25] GERARD, M.; CHAUBEY, A.; MALHOTRA, B. D. Application of conducting polymers to biosensors. Biosensors \& Bioelectronics, v. 17, n. 5, p. 345-359, 2002.

[26] RAMANATHAN, K.; RAM, M. K.; MALHOTRA, B. D.; MURTHY, A. S. N. Application of polyaniline-Langmuir-Blodgett films as a glucose biosensor. Materials Science \& Engineering C-Biomimetic Materials Sensors and Systems, v. 3, n. 3-4, p. 159163, 1995.

[27] TROJANOWICZ, M.; GESCHKE, O.; KRAWCZYK, T. K. V.; CAMMANN, K. Biosensors based on oxidases immobilized in various conducting polymers. Sensors and Actuators B-Chemical, v. 28, n. 3, p. 191-199, 1995. 
[28] SITUMORANG, M.; GOODING, J. J.; HIBBERT, D. B.; BARNETT, D.

Electrodeposited polytyramine as an immobilisation matrix for enzyme biosensors.

Biosensors \& Bioelectronics, v. 13, n. 9, p. 953-962, 1998.

[29] SCHUHMANN, W. Electron-transfer pathways in amperometric biosensors - ferrocenemodified enzymes entrapped in conducting-polymer layers. Biosensors \& Bioelectronics, v. 10, n. 1-2, p. 181-193, 1995.

[30] WRING, S. A.; HART, J. P. Chemically modified, carbon-based electrodes and their application as electrochemical sensors for the analysis of biologically important compounds a review. Analyst, v. 117, n. 8, p. 1215-1229, 1992.

[31] GARNIER, F.; HAJLAOUI, R.; YASSAR, A.; SRIVASTAVA, P. All-polymer fieldeffect transistor realized by printing techniques. Science, v. 265, n. 5179, p. 1684-1686, 1994.

[32] BREDAS, J. L.; STREET, G. B. Polarons, bipolarons, and solitons in conducting polymers. Accounts of Chemical Research, v. 18, n. 10, p. 309-315, 1985.

[33] DIAZ, A. F.; LOGAN, J. A. Electroactive polyaniline films. Journal of Electroanalytical Chemistry, v. 111, n. 1, p. 111-114, 1980.

[34] DEBERRY, D. W. Corrosion behavior of polyaniline-modified stainless-steels. Journal of the Electrochemical Society, v. 131, n. 8, p. C302-C302, 1984.

[35] KITANI, A.; IZUMI, J.; YANO, J.; HIROMOTO, Y.; SASAKI, K. Basic behaviors and properties of the electrodeposited polyaniline. Bulletin of the Chemical Society of Japan, v. 57, n. 8, p. 2254-2257, 1984.

[36] OHSAKA, T.; OHNUKI, Y.; OYAMA, N.; KATAGIRI, G.; KAMISAKO, K. Ir Absorption spectroscopic identification of electroactive and electroinactive polyaniline films prepared by the electrochemical polymerization of aniline. Journal of Electroanalytical Chemistry, v. 161, n. 2, p. 399-405, 1984.

[37] KOBAYASHI, T.; YONEYAMA, H.; TAMURA, H. Polyaniline film-coated electrodes as electrochromic display devices. Journal of Electroanalytical Chemistry, v. 161, n. 2, p. 419-423, 1984.

[38] GENIES, E. M.; TSINTAVIS, C. Redox mechanism and electrochemical-behavior of polyaniline deposits. Journal of Electroanalytical Chemistry, v. 195, n. 1, p. 109-128, 1985.

[39] PAUL, E. W.; RICCO, A. J.; WRIGHTON, M. S. Resistance of polyaniline films as a function of electrochemical potential and the fabrication of polyaniline-based microelectronic devices. Journal of Physical Chemistry, v. 89, n. 8, p. 1441-1447, 1985. 
[40] MACDIARMID, A. G.; CHIANG, J. C.; HALPERN, M.; HUANG, W. S.; MU, S. L.; SOMASIRI, N. L. D.; WU, W. Q.; YANIGER, S. I. Polyaniline - interconversion of metallic and insulating forms. Molecular Crystals and Liquid Crystals, v. 121, n. 1-4, p. 173-180, 1985.

[41] CHIANG, J. C.; MACDIARMID, A. G. Polyaniline - protonic acid doping of the emeraldine form to the metallic regime. Synthetic Metals, v. 13, n. 1-3, p. 193-205, 1986.

[42] EPSTEIN, A. J.; GINDER, J. M.; ZUO, F.; BIGELOW, R. W.; WOO, H. S.; TANNER, D. B.; RICHTER, A. F.; HUANG, W. S.; MACDIARMID, A. G. Insulator-to-metal transition in polyaniline. Synthetic Metals, v. 18, n. 1-3, p. 303-309, 1987.

[43] FOCKE, W. W.; WNEK, G. E.; WEI, Y. Influence of oxidation-state, ph, and counterion on the conductivity of polyaniline. Journal of Physical Chemistry, v. 91, n. 22, p. 58135818, 1987.

[44] KANG, E. T.; NEOH, K. G.; TAN, K. L. Polyaniline: a polymer with many interesting intrinsic redox states. Progress in Polymer Science, v. 23, n. 2, p. 277-324, 1998.

[45] HEEGER, A. J. Semiconducting and metallic polymers: The fourth generation of polymeric materials (Nobel lecture). Angewandte Chemie-International Edition, v. 40, n. 14, p. 2591-2611, 2001.

[46] GOSPODINOVA, N.; TERLEMEZYAN, L. Conducting polymers prepared by oxidative polymerization: polyaniline. Progress in Polymer Science, v. 23, n. 8, p. 43, 1998.

[47] BIALLOZOR, S.; KUPNIEWSKA, A. Conducting polymers electrodeposited on active metals. Synthetic Metals, v. 155, n. 3, p. 443-449, 2005.

[48] LU, W. K.; ELSENBAUMER, R. L.; WESSLING, B. Corrosion protection of mild-steel by coatings containing polyaniline. Synthetic Metals, v. 71, n. 1-3, p. 2163-2166, 1995.

[49] AHMAD, N.; MACDIARMID, A. G. Inhibition of corrosion of steels with the exploitation of conducting polymers. Synthetic Metals, v. 78, n. 2, p. 103-110, 1996.

[50] MORAES, S. R.; HUERTA-VILCA, D.; MOTHEO, A. J. Corrosion protection of stainless steel by polyaniline electrosynthesized from phosphate buffer solutions. Progress in Organic Coatings, v. 48, n. 1, p. 28-33, 2003.

[51] OZYILMAZ, A. T.; ERBIL, A.; YAZICI, B. Investigation of corrosion behaviour of stainless steel coated with polyaniline via electrochemical impedance spectroscopy. Progress in Organic Coatings, v. 51, n. 1, p. 47-54, 2004. 
[52] OZYILMAZ, A. T.; ERBIL, M.; YAZICI, B. The electrochemical synthesis of polyaniline on stainless steel and its corrosion performance. Current Applied Physics, v. 6, n. 1, p. 1-9, 2006.

[53] KINLEN, P. J.; MENON, V.; DING, Y. W. A mechanistic investigation of polyaniline corrosion protection using the scanning reference electrode technique. Journal of the Electrochemical Society, v. 146, n. 10, p. 3690-3695, 1999.

[54] LI, P.; TAN, T. C.; LEE, J. Y. Corrosion protection of mild steel by electroactive polyaniline coatings. Synthetic Metals, v. 88, n. 3, p. 237-242, 1997.

[55] SCHAUER, T.; JOOS, A.; DULOG, L.; EISENBACH, C. D. Protection of iron against corrosion with polyaniline primers. Progress in Organic Coatings, v. 33, n. 1, p. 20-27, 1998.

[56] MIRMOHSENI, A.; OLADEGARAGOZE, A. Anti-corrosive properties of polyaniline coating on iron. Synthetic Metals, v. 114, n. 2, p. 105-108, 2000.

[57] GASPARAC, R.; MARTIN, C. R. Investigations of the mechanism of corrosion inhibition by polyaniline - Polyaniline-coated stainless steel in sulfuric acid solution. Journal of the Electrochemical Society, v. 148, n. 4, p. B138-B145, 2001.

[58] DENG, Z.; SMYRL, W. H.; WHITE, H. S. Stabilization of metal-metal oxide surfaces using electroactive polymer-films. Journal of the Electrochemical Society, v. 136, n. 8, p. 2152-2158, 1989.

[59] SANTOS, J. R.; MATTOSO, L. H. C.; MOTHEO, A. J. Investigation of corrosion protection of steel by polyaniline films. Electrochimica Acta, v. 43, n. 3-4, p. 309-313, 1998.

[60] MOTHEO, A. J.; BISANHA, L. D. Adhesion of polyaniline on metallic surfaces. In: MOTHEO, A. J. Aspects on fundamentals and applications of conducting polymers. Rijeka: InTech, 2012. p. 19-40.

[61] MORAES, S. R.; MOTHEO, A. J. PAni-CMC: Preparation, characterization and application to corrosion protection. Molecular Crystals and Liquid Crystals, v. 448, n., p. 261-267, 2006.

[62] MORAES, S. R.; HUERTA-VILCA, D.; MOTHEO, A. J. Characteristics of polyaniline synthesized in phosphate buffer solution. European Polymer Journal, v. 40, n. 9, p. 20332041, 2004.

[63] MORAES, S. R.; HUERTA-VILCA, D.; MOTHEO, A. J. Polyaniline synthesized in phosphate buffered media applied to corrosion protection. Molecular Crystals and Liquid Crystals, v. 374, n. 1, p. 391-396, 2002. 
[64] GANGOPADHYAY, R.; DE, A. Conducting polymer nanocomposites: A brief overview. Chemistry of Materials, v. 12, n. 3, p. 608-622, 2000.

[65] ZHANG, L. J.; WAN, M. X. Polyaniline/TiO 2 composite nanotubes. Journal of Physical Chemistry B, v. 107, n. 28, p. 6748-6753, 2003.

[66] LI, X. W.; CHEN, W.; BIAN, C. Q.; HE, J. B.; XU, N.; XUE, G. Surface modification of $\mathrm{TiO}_{2}$ nanoparticles by polyanifine. Applied Surface Science, v. 217, n. 1-4, p. 16-22, 2003.

[67] FENG, W.; SUN, E. H.; FUJII, A.; WU, H. C.; NIIHARA, K.; YOSHINO, K. Synthesis and characterization of photoconducting polyaniline- $\mathrm{TiO}_{2}$ nanocomposite. Bulletin of the Chemical Society of Japan, v. 73, n. 11, p. 2627-2633, 2000.

[68] SATHIYANARAYANAN, S.; AZIM, S. S.; VENKATACHARI, G. A new corrosion protection coating with polyaniline- $\mathrm{TiO}_{2}$ composite for steel. Electrochimica Acta, v. 52, n. 5, p. 2068-2074, 2007.

[69] SATHIYANARAYANAN, S.; AZIM, S. S.; VENKATACHARI, G. Preparation of polyaniline- $\mathrm{TiO}_{2}$ composite and its comparative corrosion protection performance with polyaniline. Synthetic Metals, v. 157, n. 4-5, p. 205-213, 2007.

[70] RADHAKRISHNAN, S.; SIJU, C. R.; MAHANTA, D.; PATIL, S.; MADRAS, G. Conducting polyaniline-nano- $\mathrm{TiO}_{2}$ composites for smart corrosion resistant coatings. Electrochimica Acta, v. 54, n. 4, p. 1249-1254, 2009.

[71] MAHULIKAR, P. P.; JADHAV, R. S.; HUNDIWALE, D. G. Performance of Polyaniline/ $\mathrm{TiO}_{2}$ nanocomposites in epoxy for corrosion resistant coatings. Iranian Polymer Journal, v. 20, n. 5, p. 367-376, 2011.

[72] LAN, Y.; GAO, X. P.; ZHU, H. Y.; ZHENG, Z. F.; YAN, T. Y.; WU, F.; RINGER, S. P.; SONG, D. Y. Titanate nanotubes and nanorods prepared from rutile powder. Advanced Functional Materials, v. 15, n. 8, p. 1310-1318, 2005.

[73] SOUZA, S. A. Composição química dos aços. São Paulo: Edgard Blücher, 2006. 134p.

[74] GARCIA, C.; DE TIEDRA, M. P.; BLANCO, Y.; MARTIN, O.; MARTIN, F. Intergranular corrosion of welded joints of austenitic stainless steels studied by using an electrochemical minicell. Corrosion Science, v. 50, n. 8, p. 2390-2397, 2008.

[75] GARCIA, C.; MARTIN, F.; DE TIEDRA, P.; BLANCO, Y.; LOPEZ, M. Pitting corrosion of welded joints of austenitic stainless steels studied by using an electrochemical minicell. Corrosion Science, v. 50, n. 4, p. 1184-1194, 2008. 
[76] UNISCAN INSTRUMENTS. Modelo de equipamento para análise de espectroscopia de impedância localizada. Buxton, 2012. Disponível em: <http://www.uniscan.com>. Acesso em: 01 março 2013.

[77] APPLICABLE ELECTRONICS. Modelo de equipamento para análises pela técnica do eletrodo vibratório de varrimento. Forestdale, 2012. Disponível em: <http://www.applicableelectronics.com>. Acesso em: 01 jan. 2013.

[78] MARCUS, P.; MANSFELD, F. (Ed.). Analytical methods in corrosion science and engineering. Boca Raton: CRC, 2006. 760 p.

[79] BLUH, O.; SCOTT, B. I. H. Vibrating probe electrometer for the measurement of bioelectric potentials. Review of Scientific Instruments, v. 21, n. 10, p. 867-868, 1950.

[80] JAFFE, L. F.; NUCCITEL.R. Ultrasensitive Vibrating Probe for Measuring Steady Extracellular Currents. Journal of Cell Biology, v. 63, n. 2, p. 614-628, 1974.

[81] ISAACS, H. S. Applications of current measurement over corroding metallic surfaces. Progress in Clinical and Biological Research, v. 210, p. 37-44, 1986.

[82] SCHEFFEY, C. Pitfalls of the vibrating probe technique, and what to do about them. Progress in Clinical and Biological Research, v. 210, p. 3-12, 1986.

[83] ISAACS, H. S. The Use of the scanning vibrating electrode technique for detecting defects in ion vapor-deposited aluminum on steel. Corrosion, v. 43, n. 10, p. 594-598, 1987.

[84] ISAACS, H. S. The measurement of the galvanic corrosion of soldered copper using the scanning vibrating electrode technique. Corrosion Science, v. 28, n. 6, p. 547-558, 1988.

[85] MORAES, S. R. Síntese e caracterização de misturas de polianilina em diferentes matrizes poliméricas para proteção contra a corrosão de ligas metálicas. $2005.145 \mathrm{f}$. Tese (Doutorado) - Instituo de Química de São Carlos, Universidade de São Paulo, São Carlos, 2005.

[86] WOLYNEC, S. Técnicas eletroquímicas em corrosão. São Paulo: EDUSP, 2003. 166p.

[87] ORAZEM, M. E.; TRIBOLLET, B. Electrochemical impedance spectroscopy. Hoboken: John Wiley, 2008. 523p.

[88] SHANNON, R. R.; KINGSLAKE, R.; WYANT, J. C. Applied optics and optical engineering. New York: Academic Press, 1992. 375 p.

[89] BOZZOLA, J. J.; RUSSELL, L. D. Electron microscopy: principles and techniques for biologists. Sudbury: Jones and Bartlett, 1999. 670p. 
[90] SKOOG, D. A. Princípios de análise instrumental. Porto Alegre: Bookman, 2006. $836 \mathrm{p}$.

[91] AMERICAN SOCIETY FOR TESTING AND MATERIALS. Standard Practice for Operating Salt spray (Fog) Apparatus. B117-11. Philadelphia, 2012. 12p.

[92] DADFAR, M.; FATHI, M. H.; KARIMZADEH, F.; DADFAR, M. R.; SAATCHI, A. Effect of TIG welding on corrosion behavior of 316L stainless steel. Materials Letters, v. 61, n. 11-12, p. 2343-2346, 2007.

[93] YAN, J.; GAO, M.; ZENG, X. Y. Study on microstructure and mechanical properties of 304 stainless steel joints by TIG, laser and laser-TIG hybrid welding. Optics and Lasers in Engineering, v. 48, n. 4, p. 512-517, 2010.

[94] LU, B. T.; CHEN, Z. K.; LUO, J. L.; PATCHETT, B. M.; XU, Z. H. Pitting and stress corrosion cracking behavior in welded austenitic stainless steel. Electrochimica Acta, v. 50, n. 6, p. 1391-1403, 2005.

[95] CHAVES, I. A.; MELCHERS, R. E. Pitting corrosion in pipeline steel weld zones. Corrosion Science, v. 53, n. 12, p. 4026-4032, 2011.

[96] BABU, S. P. K.; NATARAJAN, S. Influence of heat input on high temperature weldment corrosion in submerged arc welded power plant carbon steel. Materials \& Design, v. 29, n. 5, p. 1036-1042, 2008.

[97] EROGLU, M.; AKSOY, M.; ORHAN, N. Effect of coarse initial grain size on microstructure and mechanical properties of weld metal and HAZ of a low carbon steel. Materials Science and Engineering a-Structural Materials Properties Microstructure and Processing, v. 269, n. 1-2, p. 59-66, 1999.

[98] RAMALHO, A. L.; FERREIRA, J. A. M.; BRANCO, C. A. G. M. Fatigue behaviour of $\mathrm{T}$ welded joints rehabilitated by tungsten inert gas and plasma dressing. Materials \& Design, v. 32, n. 10, p. 4705-4713, 2011.

[99] OHKO, Y.; SAITOH, S.; TATSUMA, T.; FUJISHIMA, A. Photoelectrochemical anticorrosion and self-cleaning effects of a $\mathrm{TiO}(2)$ coating for type 304 stainless steel. Journal of the Electrochemical Society, v. 148, n. 1, p. B24-B28, 2001.

[100] SARMENTO, V. H. V.; SCHIAVETTO, M. G.; HAMMER, P.; BENEDETTI, A. V.; FUGIVARA, C. S.; SUEGAMA, P. H.; PULCINELLI, S. H.; SANTILLI, C. V. Corrosion protection of stainless steel by polysiloxane hybrid coatings prepared using the sol-gel process. Surface \& Coatings Technology, v. 204, n. 16-17, p. 2689-2701, 2010. 
[101] PEREDA, M. D.; GERVASI, C. A.; LLORENTE, C. L.; BILMES, P. D. Microelectrochemical corrosion study of super martensitic welds in chloride-containing media. Corrosion Science, v. 53, n. 12, p. 3934-3941, 2011.

[102] JURAGA, I.; SIMUNOVIC, V.; SPANICEK, D. Contribution to the study of effects of surface state of welded joints in stainless steel upon resistance towards pitting corrosion. Metalurgija, v. 46, n. 3, p. 185-189, 2007.

[103] SAZOU, D.; KOUROUZIDOU, M.; PAVLIDOU, E. Potentiodynamic and potentiostatic deposition of polyaniline on stainless steel: Electrochemical and structural studies for a potential application to corrosion control. Electrochimica Acta, v. 52, n. 13, p. 4385-4397, 2007.

[104] MRAD, M.; DHOUIBI, L.; TRIKI, E. Dependence of the corrosion performance of polyaniline films applied on stainless steel on the nature of electropolymerisation solution. Synthetic Metals, v. 159, n. 17-18, p. 1903-1909, 2009.

[105] SATHIYANARAYANAN, S.; DEVI, S.; VENKATACHARI, G. Corrosion protection of stainless steel by electropolymerised pani coating. Progress in Organic Coatings, v. 56, n. 2-3, p. 114-119, 2006.

[106] HUH, J. H.; OH, E. J.; CHO, J. H. Corrosion characteristics of electrochemically prepared phosphate doped polyaniline films in acidic chloride environments. Synthetic Metals, v. 153, n. 1-3, p. 13-16, 2005.

[107] CACERES, L.; VARGAS, T.; HERRERA, L. Influence of pitting and iron oxide formation during corrosion of carbon steel in unbuffered $\mathrm{NaCl}$ solutions. Corrosion Science, v. 51, n. 5, p. 971-978, 2009.

[108] REN, R. K.; ZHANG, S.; PANG, X. L.; GAO, K. W. A novel observation of the interaction between the macroelastic stress and electrochemical corrosion of low carbon steel in $3.5 \mathrm{wt} \% \mathrm{NaCl}$ solution. Electrochimica Acta, v. 85, p. 283-294, 2012.

[109] FUSHIMI, K.; NAGANUMA, A.; AZUMI, K.; KAWAHARA, Y. Current distribution during galvanic corrosion of carbon steel welded with type-309 stainless steel in $\mathrm{NaCl}$ solution. Corrosion Science, v. 50, n. 3, p. 903-911, 2008.

[110] MA, Y. T.; LI, Y.; WANG, F. H. Corrosion of low carbon steel in atmospheric environments of different chloride content. Corrosion Science, v. 51, n. 5, p. 997-1006, 2009.

[111] LIN, B.; HU, R. G.; YE, C. Q.; LI, Y.; LIN, C. J. A study on the initiation of pitting corrosion in carbon steel in chloride-containing media using scanning electrochemical probes. Electrochimica Acta, v. 55, n. 22, p. 6542-6545, 2010. 
[112] REFFASS, M.; SABOT, R.; SAVALL, C.; JEANNIN, M.; CREUS, J.; REFAIT, P. Localised corrosion of carbon steel in $\mathrm{NaHCO} 3 / \mathrm{NaCl}$ electrolytes: role of $\mathrm{Fe}(\mathrm{II})$-containing compounds. Corrosion Science, v. 48, n. 3, p. 709-726, 2006.

[113] HEMMINGSEN, T.; HOVDAN, H.; SANNI, P.; AAGOTNES, N. O. The influence of electrolyte reduction potential on weld corrosion. Electrochimica Acta, v. 47, n. 24, p. 39493955, 2002.

[114] SHEN, G. X.; CHEN, Y. C.; LIN, C. J. Corrosion protection of 316 L stainless steel by a $\mathrm{TiO}_{2}$ nanoparticle coating prepared by sol-gel method. Thin Solid Films, v. 489, n. 1-2, p. 130-136, 2005.

[115] YUN, H.; LI, J.; CHEN, H. B.; LIN, C. J. A study on the N-, S- and Cl-modified nano$\mathrm{TiO}_{2}$ coatings for corrosion protection of stainless steel. Electrochimica Acta, v. 52, n. 24, p. 6679-6685, 2007.

[116] LEE, J. H.; JANG, G. E.; JUN, Y. H. Investigation and evaluation of structural color of $\mathrm{TiO}_{2}$ coating on stainless steel. Ceramics International, v. 38, p. S661-S664, 2012.

[117] BANNIER, E.; DARUT, G.; SANCHEZ, E.; DENOIRJEAN, A.; BORDES, M. C.; SALVADOR, M. D.; RAYON, E.; AGEORGES, H. Microstructure and photocatalytic activity of suspension plasma sprayed $\mathrm{TiO}_{2}$ coatings on steel and glass substrates. Surface $\&$ Coatings Technology, v. 206, n. 2-3, p. 378-386, 2011.

[118] WANG, H. F.; SHU, X. F.; LI, X. Y.; TANG, B. Photocatalytic activities of N doped $\mathrm{TiO}_{2}$ coatings on 316L stainless steel by plasma surface alloying technique. Transactions of Nonferrous Metals Society of China, v. 22, p. S120-S126, 2012.

[119] KRISHNA, D. S. R.; SUN, Y. Thermally oxidised rutile-TiO ${ }_{2}$ coating on stainless steel for tribological properties and corrosion resistance enhancement. Applied Surface Science, v. 252, n. 4, p. 1107-1116, 2005.

[120] DAI, W. W.; DING, C. X.; LI, J. F.; ZHANG, Y. F.; ZHANG, P. Y. Wear mechanism of plasma-sprayed $\mathrm{TiO}_{2}$ coating against stainless steel. Wear, v. 196, n. 1-2, p. 238-242, 1996.

[121] VIGIL, E.; DIXON, D.; HAMILTON, J. W. J.; BYRNE, J. A. Deposition of $\mathrm{TiO}_{2}$ thin films on steel using a microwave activated chemical bath. Surface \& Coatings Technology, v. 203, n. 23, p. 3614-3617, 2009.

[122] YUSOFF, N. H. N.; GHAZALI, M. J.; ISA, M. C.; DAUD, A. R.; MUCHTAR, A. Effects of powder size and metallic bonding layer on corrosion behaviour of plasma-sprayed $\mathrm{Al}_{2} \mathrm{O}_{3}-13 \% \mathrm{TiO}_{2}$ coated mild steel in fresh tropical seawater. Ceramics International, v. 39, n. 3, p. 2527-2533, 2013. 
[123] WANG, A. H.; TAO, Z. Y.; ZHU, B. D.; FU, J. M.; MA, X. Y.; DENG, S. J.; CHENG, X. D. Laser modification of plasma-sprayed Al2O3-13wt-Percent- $\mathrm{TiO}_{2}$ Coatings on a LowCarbon Steel. Surface \& Coatings Technology, v. 52, n. 2, p. 141-144, 1992.

[124] WANG, Y.; TIAN, W.; ZHANG, T.; YANG, Y. Microstructure, spallation and corrosion of plasma sprayed $\mathrm{Al} 2 \mathrm{O} 3-13 \% \mathrm{TiO}_{2}$ coatings. Corrosion Science, v. 51, n. 12, p. 2924-2931, 2009.

[125] YUSOFF, N. H. N.; GHAZALI, M. J.; ISA, M. C.; DAUD, A. R.; MUCHTAR, A.; FORGHANI, S. M. Optimization of plasma spray parameters on the mechanical properties of agglomerated $\mathrm{Al}_{2} \mathrm{O}_{3}-13 \% \mathrm{TiO}_{2}$ coated mild steel. Materials \& Design, v. 39, n., p. 504-508, 2012.

[126] KUSOGU, I. M.; CELIK, E.; CETINEL, H.; OZDEMIR, I.; DEMIRKURT, O.; ONEL, $\mathrm{K}$. Wear behavior of flame-sprayed $\mathrm{Al}_{2} \mathrm{O}_{3}-\mathrm{TiO}_{2}$ coatings on plain carbon steel substrates. Surface \& Coatings Technology, v. 200, n. 1-4, p. 1173-1177, 2005.

[127] YE, F. X.; OHMORI, A. The photocatalytic activity and photo-absorption of plasma sprayed $\mathrm{TiO}_{2}-\mathrm{Fe}_{3} \mathrm{O}_{4}$ binary oxide coatings. Surface \& Coatings Technology, v. 160, n. 1, p. 62-67, 2002.

[128] HERRASTI, P.; KULAK, A. N.; BAVYKIN, D. V.; DE LEON, C. P.; ZEKONYTE, J.; WALSH, F. C. Electrodeposition of polypyrrole-titanate nanotube composites coatings and their corrosion resistance. Electrochimica Acta, v. 56, n. 3, p. 1323-1328, 2011.

[129] GOSPODINOVA, N.; TERLEMEZYAN, L.; MOKREVA, P.; KOSSEV, K. On the mechanism of oxidative polymerization of aniline. Polymer, v. 34, n. 11, p. 2434-2437, 1993.

[130] AHMED, S. M. Mechanistic investigation of the oxidative polymerization of aniline hydrochloride in different media. Polymer Degradation and Stability, v. 85, n. 1, p. $605-$ 614, 2004.

[131] BIAN, C. Q.; YU, Y. J.; XUE, G. Synthesis of conducting polyaniline/TiO 2 composite nanofibres by one-step in situ polymerization method. Journal of Applied Polymer Science, v. 104, n. 1, p. 21-26, 2007.

[132] NABID, M. R.; GOLBABAEE, M.; MOGHADDAM, A. B.; DINARVAND, R.; SEDGHI, R. Polyaniline/ $\mathrm{TiO}_{2}$ nanocomposite: Enzymatic synthesis and electrochemical properties. International Journal of Electrochemical Science, v. 3, n. 10, p. 1117-1126, 2008.

[133] MAIRA, A. J.; CORONADO, J. M.; AUGUGLIARO, V.; YEUNG, K. L.; CONESA, J. C.; SORIA, J. Fourier transform infrared study of the performance of nanostructured $\mathrm{TiO}_{2}$ particles for the photocatalytic oxidation of gaseous toluene. Journal of Catalysis, v. 202, n. 2, p. 413-420, 2001. 
[134] GONZALEZ, R. J.; ZALLEN, R.; BERGER, H. Infrared reflectivity and lattice fundamentals in anatase $\mathrm{TiO}_{2}$. Physical Review B, v. 55, n. 11, p. 7014-7017, 1997.

[135] SAVITHA, K. U.; PRABU, H. G. One-pot synthesis of PANI-TiO2 (anatase) hybrid of low electrical resistance using TiCl4 as precursor. Materials Chemistry and Physics, v. 130, n. 1-2, p. 275-279, 2011.

[136] WESSLING, B. Passivation of Metals by Coating with Polyaniline - Corrosion Potential Shift and Morphological-Changes. Advanced Materials, v. 6, n. 3, p. 226-228, 1994.

[137] ZHONG, L.; WANG, Y. H.; LU, Y. H. Synthesis, characterization and corrosion protection properties of polyaniline/TiO2 nanocomposite. New Materials, Applications and Processes, Pts 1-3, v. 399-401, n., p. 2083-2086, 2012.

[138] JADHAV, R. S.; HUNDIWALE, D. G.; MAHULIKAR, P. P. Synthesis of nano polyaniline and poly-o-anisidine and applications in alkyd paint formulation to enhance the corrosion resistivity of mild steel. Journal of Coatings Technology and Research, v. 7, n. 4, p. 449-454, 2010.

[139] LEE, I. S.; LEE, J. Y.; SUNG, J. H.; CHOI, H. J. Synthesis and electrorheological characteristics of polyaniline-titanium dioxide hybrid suspension. Synthetic Metals, v. 152, n. 1-3, p. 173-176, 2005.

[140] PAWAR, S. G.; PATIL, S. L.; CHOUGULE, M. A.; MANE, A. T.; JUNDALE, D. M.; PATIL, V. B. Synthesis and Characterization of Polyaniline:TiO2 Nanocomposites.

International Journal of Polymeric Materials, v. 59, n. 10, p. 777-785, 2010.

[141] PAWAR, S. G.; CHOUGULE, M. A.; PATIL, S. L.; RAUT, B. T.; GODSE, P. R.; SEN, S.; PATIL, V. B. Room Temperature Ammonia Gas Sensor Based on Polyaniline-TiO2 Nanocomposite. Ieee Sensors Journal, v. 11, n. 12, p. 3417-3423, 2011.

[142] WANG, Y. Y.; JING, X. L. Effect of solution concentration on the UV-vis spectroscopy measured oxidation state of polyaniline base. Polymer Testing, v. 24, n. 2, p. 153-156, 2005.

[143] MATTOSO, L. H. C. Polianilinas: síntese, estrutura e propriedades. Química Nova, v. 19, n. 4, p. 12, 1996.

[144] PAWAR, S. G.; PATIL, S. L.; CHOUGULE, M. A.; RAUT, B. T.; GODASE, P. R.; MULIK, R. N.; SEN, S.; PATIL, V. B. New Method for Fabrication of CSA Doped PANiTiO2 Thin-Film Ammonia Sensor. Ieee Sensors Journal, v. 11, n. 11, p. 2980-2985, 2011. 
[145] GANESAN, R.; GEDANKEN, A. Organic-inorganic hybrid materials based on polyaniline/TiO(2) nanocomposites for ascorbic acid fuel cell systems. Nanotechnology, v. 19, n. 43, 2008.

[146] TAI, H. L.; JIANG, Y. D.; XIE, G. Z.; YU, J. S. Preparation, Characterization and Comparative NH3-sensing Characteristic Studies of PANI/inorganic Oxides Nanocomposite Thin Films. Journal of Materials Science \& Technology, v. 26, n. 7, p. 605-613, 2010.

[147] YAVUZ, A. G.; GOK, A. Preparation of TiO2/PANI composites in the presence of surfactants and investigation of electrical properties. Synthetic Metals, v. 157, n. 4-5, p. 235242, 2007.

[148] SATHIYANARAYANAN, S.; AZIM, S. S.; VENKATACHARI, G. Corrosion protection coating containing polyaniline glass flake composite for steel. Electrochimica Acta, v. 53, n. 5, p. 2087-2094, 2008.

[149] TAN, C. K.; BLACKWOOD, D. J. Corrosion protection by multilayered conducting polymer coatings. Corrosion Science, v. 45, n. 3, p. 545-557, 2003.

[150] HERRASTI, P.; RECIO, F. J.; OCON, P.; FATAS, E. Effect of the polymer layers and bilayers on the corrosion behaviour of mild steel: Comparison with polymers containing $\mathrm{Zn}$ microparticles. Progress in Organic Coatings, v. 54, n. 4, p. 285-291, 2005.

[151] YAO, B.; WANG, G. C.; YE, J. K.; LI, X. W. Corrosion inhibition of carbon steel by polyaniline nanofibers. Materials Letters, v. 62, n. 12-13, p. 1775-1778, 2008. 